Campbell Systematic Reviews 2009:1

First published: 21 January, 2009

Last updated: $\quad 21$ January, 2009

\title{
Kinship Care for the Safety, Permanency, and Well-being of Children Removed from the Home for Maltreatment
}

Marc Winokur, Amy Holtan, Deborah Valentine 


\section{Colophon}

Title Kinship care for the safety, permanency, and well-being of children removed from the home for maltreatment.

Institution The Campbell Collaboration

Authors Winokur, Mark

Holtan, Amy

Valentine, Deborah

DOI $10.4073 /$ csr.2009.1

No. of pages 171

Last updated 21 January, 2009

Citation Winokur M, Holtan A, Valentine D. Kinship care for the safety, permanency, and well-being of children removed from the home for maltreatment.

Campbell Systematic Reviews 2008:16

DOI: 10.4073/csr.2009.1

Copyright (C) Winokur et al.

This is an open-access article distributed under the terms of the Creative Commons Attribution License, which permits unrestricted use, distribution, and reproduction in any medium, provided the original author and source are credited.

Co-registration This review is co-registered within both the Cochrane and Campbell Collaborations. A version of this review can also be found in the Cochrane Library.

Keywords

Contributions Marc Winokur, Amy Holtan, and Deborah Valentine contributed to the writing and revising of this protocol. The search strategy was developed with Jo Abbott, Trial Search Coordinator for the Cochrane DPLPG. Marc Winokur will be responsible for updating this review as additional evidence accumulates and as funding becomes available.

Support/Funding SFI Campbell, The Danish National Centre of Social Research, Denmark Applied Research in Child Welfare Project, USA

Potential Conflicts Marc Winokur, Amy Holtan, and Deborah Valentine have no vested interest of Interest in the outcomes of this review, nor any incentive to represent findings in a biased manner.

Corresponding Marc Winokur

author Social Work Research Center / School of Social Work

Colorado State University

110 Education

Fort Collins, Colorado 80523

USA

E-mail: marc.winokur@colostate.edu 


\title{
Campbell Systematic Reviews
}

\author{
Editors-in-Chief Mark W. Lipsey, Vanderbilt University, USA \\ Arild Bjørndal, Norwegian Knowledge Centre for the Health Services
}

Managing Editor Karianne Thune Hammerstrøm, The Campbell Collaboration

Editorial Board

Crime and Justice David B. Wilson, George Mason University, USA

Education Chad Nye, University of Central Florida, USA

Ralf Schlosser, Northeastern University, USA

Social Welfare Julia Littell, Bryn Mawr College, USA

Geraldine Macdonald, Queen's University, UK \& Cochrane Developmental, Psychosocial and Learning Problems Group

The Campbell Collaboration (C2) was founded on the principle that systematic reviews on the effects of interventions will inform and help improve policy and services. C2 offers editorial and methodological support to review authors throughout the process of producing a systematic review. A number of C2's editors, librarians, methodologists and external peerreviewers contribute.

The Campbell Collaboration P.O. Box 7004 St. Olavs plass 0130 Oslo, Norway www.campbellcollaboration.org 


\section{Table of contents}

$\begin{array}{lr}\text { TABLE OF CONTENTS } & 1\end{array}$

KEY MESSAGES

EXECUTIVE SUMMARY/ABSTRACT

Background $\quad 5$

Objectives $\quad 5$

Search Strategy $\quad 5$

Selection Criteria $\quad 5$

Data collection and Analysis $\quad 6$

$\begin{array}{ll}\text { Results } & 6\end{array}$

$\begin{array}{ll}\text { authors' Conclusions } & 6\end{array}$

1 BACKGROUND $\quad 7$

$\begin{array}{lll}1.1 & \text { Description of the condition } & 7\end{array}$

1.2 Description of the intervention 8

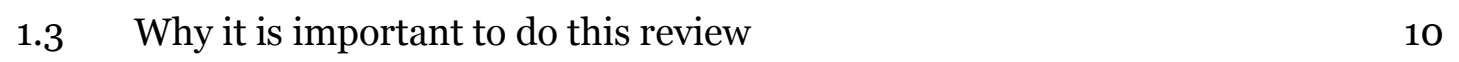

2 OBJECTIVES OF THE REVIEW 12

3 METHODS $\quad 13$

$\begin{array}{ll}3.1 & \text { Criteria for considering studies for this review } \\ & 13\end{array}$

$\begin{array}{ll}3.2 & \text { Search methods for identification of studies } \\ 3.3 & 15\end{array}$

$\begin{array}{lll}3.3 & \text { Data collection and analysis } & 16\end{array}$

4 RESULTS $\quad 19$

$\begin{array}{lll}4.1 & \text { Description of studies } & 19\end{array}$

4.2 Risk of bias in included studies $\quad 24$

$\begin{array}{lll}4.3 & \text { Effects of interventions } & 26\end{array}$

5 DISCUSSION $\quad 34$

5.1 Summary of main results 34

5.2 Overall completeness and applicability of evidence 34

5.3 Quality of the evidence 35

5.4 Potential biases in the review process 36

5.5 Agreements and disagreements with other studies or reviews 36

$\begin{array}{llr}6 & \text { AUTHORS' CONCLUSIONS } & 37\end{array}$ 
$\begin{array}{ll}\text { 6.1 Implications for practice } & 37\end{array}$

$\begin{array}{lll}6.2 & \text { Implications for research } & 37\end{array}$

$7 \quad$ ACKNOWLEDGEMENTS

8 CHARACTERISTICS OF STUDIES 40

8.1 Characteristics of included studies 40

$\begin{array}{lll}8.2 & \text { Characteristics of excluded studies } & 59\end{array}$

$\begin{array}{lll}\text { 8.3 Characteristics of studies awaiting classification } & 77\end{array}$

9 ADDITIONAL TABLES $\quad 79$

$\begin{array}{lll}9.1 & \text { Outcomes for Studies with Multivariate Analysis } & 79\end{array}$

9.2 Outcomes for Studies with Bivariate Analysis 82

$\begin{array}{lll}9.3 & \text { Quality Assessment Ratings } & 83\end{array}$

9.4 Methods for Future Updates 85

9.5 Participant Baseline Characteristics $\quad 85$

$\begin{array}{lll}9.6 & \text { Intervention Characteristics } & 91\end{array}$

9.7 Outcome Measures 95

10 REFERENCES TO STUDIES

$\begin{array}{lll}10.1 & \text { Included studies } & 119\end{array}$

$\begin{array}{lll}10.2 & \text { Excluded studies } & 124\end{array}$

$\begin{array}{lll}10.3 & \text { Studies awaiting classification } & 142\end{array}$

$\begin{array}{lll}10.4 & \text { Ongoing studies } & 142\end{array}$

$\begin{array}{ll}10.5 & \text { Additional references } \\ & 142\end{array}$

11 DATA AND ANALYSES 146

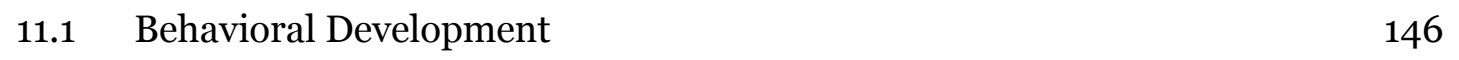

$\begin{array}{lll}11.2 & \text { Mental Health } & 146\end{array}$

$\begin{array}{lll}11.3 & \text { Placement Stability } & 146\end{array}$

$\begin{array}{lll}11.4 & \text { Permanency } & 147\end{array}$

$\begin{array}{lll}11.5 & \text { Educational Attainment } & 147\end{array}$

$\begin{array}{lll}11.6 & \text { Family Relations } & 147\end{array}$

$\begin{array}{lll}11.7 & \text { Service Utilization } & 148\end{array}$

$\begin{array}{lll}11.8 & \text { Re-abuse } & 148\end{array}$

$\begin{array}{llr}12 & \text { FIGURES } & 149\end{array}$

13 SOURCES OF SUPPORT

$\begin{array}{lll}13.1 & \text { Internal sources } & 150\end{array}$

$\begin{array}{lll}13.2 & \text { External sources } & 150\end{array}$

14 APPENDICES $\quad \mathbf{1 5 1}$

14.1 Cochrane Library (CENTRAL) search strategy 151

$\begin{array}{lll}14.2 & \text { MEDLINE search strategy } & 151\end{array}$

$\begin{array}{lll}14.3 & \text { C2-SPECTR search strategy } & 152\end{array}$

$\begin{array}{lll}14.4 & \text { Sociological Abstracts search strategy } & 152\end{array}$ 
$\begin{array}{lll}14.5 & \text { Social Work Abstracts search strategy } & 152\end{array}$

14.6 Social Science Citation Index and ISI Proceedings search strategy 153

14.7 Family and Society Studies Worldwide search strategy 154

$\begin{array}{lll}14.8 & \text { ERIC search strategy } & 154\end{array}$

$\begin{array}{lll}14.9 & \text { PsycINFO search strategy } & 155\end{array}$

$\begin{array}{ll}14.10 & \text { CINAHL search strategy } \\ 14.11 & 156\end{array}$

$\begin{array}{lll}14.11 & \text { ASSIA search strategy } & 156\end{array}$

14.12 Dissertation Abstracts International search strategy 157

15 DATA AND ANALYSES $\quad 158$

$\begin{array}{lll}15.1 & \text { Behavioral development outcomes } & 158\end{array}$

$\begin{array}{ll}15.2 & \text { Mental Health } \\ 15.3 & 159\end{array}$

$\begin{array}{lll}15.3 & \text { Placement Stability Outcomes } & 161\end{array}$

$\begin{array}{lll}15.4 & \text { Permanency Outcomes } & 164\end{array}$

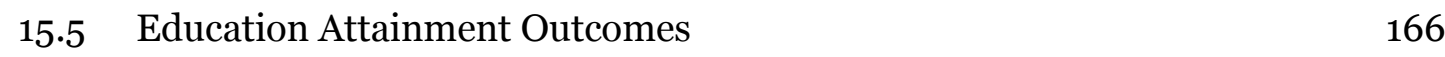

$\begin{array}{lll}15.6 & \text { Family Relations } & 167\end{array}$

$\begin{array}{lll}15.7 & \text { Service Utilization Outcomes } & 169\end{array}$

$\begin{array}{lll}15.8 & \text { Re-abuse Outcomes } & 170\end{array}$ 


\section{Key messages}

Child abuse and neglect are common problems across the world that result in negative consequences for children, families and communities. Children who have been abused or neglected are often removed from the home and placed in residential care or with other families, including foster families. Foster care was traditionally provided by people that social workers recruited from the community specifically to provide care for children whose parents could not look after them. Typically they were not related to the children placed with them, and did not know them before the placement was arranged. In recent years many societies have introduced policies that favour placing children who cannot live at home with other members of their family or with friends of the family. This is known as 'kinship care' or 'families and friends care'. We do not know what type of out-of-home care (placement) is best for children.

This review was designed to help find out if research studies could tell us which kind of placement is best. Sixty two studies met the methodological standards we considered acceptable. Wherever possible we combined the data from studies looking at the same outcome for children, in order to be more confident about what the research was telling us. Current best evidence suggests that children in kinship care may do better than children in traditional foster care in terms of their behavioral development, mental health functioning, and placement stability. Children in traditional foster care placements may do better with regard to achieving some permanency outcomes and accessing services they may need. Implications for practice and future research are discussed. 


\section{Executive summary/Abstract}

\section{BACKGROUND}

Every year a large number of children around the world are removed from their homes because they are maltreated. Child welfare agencies are responsible for placing these children in out-of-home settings that will facilitate their safety, permanency, and well-being. However, children in out-of-home placements typically display more educational, behavioral, and psychological problems than do their peers, although it is unclear whether this results from the placement itself, the maltreatment that precipitated it, or inadequacies in the child welfare system.

\section{OBJECTIVES}

To evaluate the effect of kinship care placement on the safety, permanency, and well-being of children removed from the home for maltreatment.

\section{SEARCH STRATEGY}

The following databases were searched to February 2007: CENTRAL, MEDLINE, C2-Spectr, Sociological Abstracts, Social Work Abstracts, SSCI, Family and Society Studies Worldwide, ERIC, PsycINFO, ISI Proceedings, CINAHL, ASSIA, and Dissertation Abstracts International. Relevant social work journals and reference lists of published literature reviews were handsearched, and authors contacted.

\section{SELECTION CRITERIA}

Randomized experimental and quasi-experimental studies, in which children removed from the home for maltreatment and subsequently placed in kinship foster care, were compared with children placed in non-kinship foster care on child welfare outcomes in the domains of well-being, permanency, or safety. 
Reviewers independently read the titles and abstracts identified in the search and selected appropriate studies. Reviewers assessed the eligibility of each study for the evidence base and then evaluated the methodological quality of the included studies. Lastly, outcome data were extracted and entered into REVMAN for meta-analysis with the results presented in written and graphical forms.

\section{RESULTS}

Sixty two quasi-experimental studies were included in this review. Data suggest that children in kinship foster care experience better behavioral development, mental health functioning, and placement stability than do children in non-kinship foster care. Although there was no difference on reunification rates, children in nonkinship foster care were more likely to be adopted while children in kinship foster care were more likely to be in guardianship. Lastly, children in non-kinship foster care were more likely to utilize mental health services.

\section{AUTHORS' CONCLUSIONS}

This review supports the practice of treating kinship care as a viable out-of-home placement option for children removed from the home for maltreatment. However, this conclusion is tempered by the pronounced methodological and design weaknesses of the included studies. 


\section{Background}

\subsection{DESCRIPTION OF THE CONDITION}

Every year a large number of children around the world are removed from their homes because they are abused, neglected, or otherwise maltreated. For example, there were 513,000 children in out-of-home placements in the United States as of September 2005 (USDHHS 2006b), 60,900 children in public care in England as of March 2005 (DFES 2005), 23,965 children in out-of-home care in Australia as of June 2005 (AIHW 2006), 12,185 children in public care in Scotland as of March 2005 (SENS 2005), 4,668 children in public care in Wales as of March 2005 (NAW 2005), 6,120 children in public care in Norway as of December 2006 (SN 2007), and 7,678 children in out-of-home care in Israel as of 2007 (CBS 2007).

The main reasons for the removal of children in the United States are neglect, physical abuse, sexual abuse, psychological maltreatment, abandonment, threats of harm, and drug addiction (USDHHS 2006a). Abuse and neglect are the most prevalent causes of children being removed from the home in other countries as well (e.g. Wales) (NAW 2005). Internationally, child welfare systems are accountable for the safety, permanency, and wellbeing of children in their care. For children removed from the home, child welfare professionals are responsible for placing them in out-of-home settings that will facilitate these outcomes. Specifically, the primary placement options are traditional foster care, kinship care, residential treatment centers, and group homes (USDHHS 2006b; AIHW 2006). Children in out-of-home placements typically display more educational, behavioral, physical, and psychological problems than do their peers (Gleeson 1999), although it is unclear whether this results from the placement itself, the maltreatment that precipitated it, or inadequacies in the child welfare system. In addition to experiencing poor adult outcomes, these children are at risk for drifting in out-ofhome care until, in some cases, they "graduate" from the system because of age (Zuravin 1999). 


\subsection{DESCRIPTION OF THE INTERVENTION}

\section{Kinship Care}

Kinship care is broadly defined as, "the full-time nurturing and protection of children who must be separated from their parents, by relatives, members of their tribes or clans, godparents, stepparents, or other adults who have a kinship bond with a child" (CWLA 1994, p. 2). This is contrasted with traditional foster care or non-kinship foster care, which is the placement of children removed from the home with unrelated foster parents. Kinship care is known by many other names around the world, including family and friends care in the United Kingdom, kith and kin care in Australia, and kinship foster care in the United States. For this review, kinship care will refer to kinship foster care placements, while foster care will refer to non-kinship foster care placements.

There are several variations of kinship care including formal, informal, and private placements. Formal kinship care is a legal arrangement in which a child welfare agency has custody of a child (Ayala-Quillen 1998). Informal kinship care is when a child welfare agency assists in the placement of a child but does not seek custody (Geen 2000). Private kinship care is a voluntary arrangement between the birth parents and family members without the involvement of a child welfare agency (Dubowitz 1994a).

The most commonly perceived benefits are that kinship care "enables children to live with persons whom they know and trust, reduces the trauma children may experience when they are placed with persons who are initially unknown to them, and reinforces children's sense of identity and self esteem which flows from their family history and culture" (Wilson 1996, p. 387). The primary aims of kinship placements are family preservation, in which the permanency goal is reunification with birth parents, and substitute care, in which kinship care is considered to be a long-term arrangement when restoration is not possible or the permanency goal is adoption or guardianship by kin caregivers (Scannapieco 1999). Kinship care also is considered to be the least restrictive (Scannapieco 1999) and safest setting (Gleeson 1999) on the continuum of out-of-home placements.

\section{Intervention Context}

Although an ancient practice in many cultures, formal kinship care is a newer placement paradigm in countries like the United States and Australia due to its recent adoption by the child welfare field as the placement of choice, when appropriate, in the continuum of out-of home care services for children (Ainsworth 1998; Geen 2000; Scannapieco 1999). For example, the Personal Responsibility and Work Opportunity Reconciliation Act of 1996 explicitly required American states to give preference to family members when placing a child outside of the home (Leos- 
Urbel 2002). The most recent United States legislation, the Adoption and Safe Families Act of 1997, continues this federal commitment towards promoting and supporting kinship care (Ayala-Quillen 1998). In Australia, the Aboriginal Child Placement Principle has resulted in the increased use of kinship placements, although this differs by state or territory (Paxman 2006). In addition, the New South Wales Children and Young Persons (Care and Protection) Act 1998 encourages the "least intrusive" principle, which is interpreted by caseworkers as placements with kin (Spence 2004). In some European countries, there also has been a shift in policy regarding kinship placements. Specifically, the Children Act 1989 (United Kingdom), the Children Act 1995 (Scotland), and the Children Order 1995 (Northern Ireland) are generally supportive of kinship care (Broad 2005a). However, there is no legislation in Israel concerning kinship care and a lack of consensus about how to define and serve the population of children at risk for maltreatment (Schmid 2007).

For the countries included in this review (i.e. re-entry Australia, Israel, Netherlands, Norway, Sweden, and U.S.), there are essential differences in child welfare policy and practice for placing children in out-of-home care. Outside of the U.S., long-term foster or kinship care is the preferred placement, which implies that parents have right of access to their child provided it is not considered damaging, and also a right to express their opinion on important issues like education and religion. In Australia, Israel, Netherlands, Norway, and Sweden, foster care placement is not time-limited and can be extended until the child emancipates from care (e.g. Strijker 2003). Because, the preferred option is long-term stable placements, there are foster children in Norway and Sweden who remain in foster homes throughout their entire childhood (e.g. Sallnas 2004). Thus, the concept of breakdown (premature termination of placement) is therefore a more relevant measure in the evaluation of foster care than is reunification or adoption (Sallnas 2004).

During the past 15 years in many countries, there has been a rapid increase in the number of children removed from home and placed with relatives (Cuddeback 2004). The main reasons for the growth of this placement option include an influx of abused and neglected children into out-of-home care (Berrick 1998), concern about poor outcomes for children leaving care (Broad 2005b), a persistent shortage in foster care homes (Berrick 1998), and a shift in policy toward treating kin as appropriate caregivers with all of the legal rights and responsibilities of foster parents (Leos-Urbel 2002). In New South Wales, Australia, the most important factor accounting for historically high numbers of children in foster care is the low use of residential care (Tarren-Sweeney 2006). However, residential care is the preferred out-of-home placement setting for older children in Israel and Sweden (Mosek 2001; Sallnas 2004).

Similar to other child welfare interventions, kinship care is faced with its fair share of controversial issues. The major controversy centers on the unequal financial 
support (Brooks 2002) and service provision received by kinship caregivers as compared with traditional foster parents (Dubowitz 1994a). The licensing and certification of kinship caregivers also is a source of much disagreement and dissatisfaction (Gibbs 2000). Relatedly, the appropriate level of oversight of kinship caregivers by child welfare agencies is another area of discord (Cohen 1999). One of the key debates is over the appropriate level of involvement for biological parents prior to and after the removal of their children (Ayala-Quillen 1998). In a comprehensive review of the U.S. literature, Cuddeback 2004 confirmed much of the conventional wisdom about kinship care while identifying many of the weaknesses of quantitative research on the topic. Cuddeback found that kinship caregivers are more likely to be older, single, less educated, unemployed, and poor than are foster parents and noncustodial grandparents. Furthermore, Cuddeback reported that kin caregivers report less daily physical activity, more health problems, higher levels of depression, and less marital satisfaction. Cuddeback also concluded that kinship care families receive less training, services, and financial support than do foster care families. In addition, Cuddeback reported that birth parents rarely receive family preservation services, which means that children in kinship care are less likely than children in foster care to be reunified. Lastly, Cuddeback found inconclusive evidence that children in kinship care have greater problems related to overall functioning than do children in foster care.

\subsection{WHY IT IS IMPORTANT TO DO THIS REVIEW}

Geen 2004 argues that, "despite the centrality of kinship foster care in child welfare, our understanding of how best to utilize and support kin caregivers, and the impact of kinship foster care on child development, is limited" (p. 144). Specifically, social work researchers have not kept up with the exponential growth of kinship care as a placement option (Berrick 1994; Dubowitz 1994a). Furthermore, much of the research supporting kinship care is anecdotal and conjectural, which does not allow child welfare professionals to make evidence-based decisions from comparisons of children in out-of-home care (Goerge 1994). For example, there is great interest in the safety and well-being of children placed in kinship care, but very little experimental research on these outcomes (Gibbs 2000). Ethical standards preclude the random assignment of children to kinship or foster care, as these placements typically are based on the appropriateness and availability of kinship caregivers or foster parents (Barth 2008). However, Barth 2008 have identified several recent studies which employed propensity score matching as a means of statistically simulating random assignment to placement conditions.

We addressed these methodological challenges by identifying and synthesizing the most strongly designed and executed studies available on this topic. Unfortunately, the best available evidence on kinship care was seriously lacking in many ways, especially in regard to controlling for baseline differences in non-randomized studies. Although some would argue that this should disqualify kinship care, along 
with similar social work interventions, from being systematically reviewed, we believe that practitioners and policymakers benefit more from examining poor evidence than no evidence at all. 


\section{Objectives of the Review}

To evaluate the effect of kinship care placement compared to foster care placement on the safety, permanency, and well-being of children removed from the home for maltreatment. 


\section{Methods}

\subsection{CRITERIA FOR CONSIDERING STUDIES FOR THIS REVIEW}

\section{Types of studies}

Randomized experimental and quasi-experimental studies, in which children placed in kinship care are compared cross-sectionally or longitudinally with children placed in foster care. The types of eligible quasi-experimental designs include studies that employ matching, covariates, or ex post facto comparisons of children in kinship care and foster care. Studies that compare kinship care to more restrictive out-ofhome settings (e.g. residential treatment centers) were not considered for this review. Relative to children who are placed in kinship or foster care, children placed in more restrictive settings tend to differ in important ways. These differences complicate inferences about the effects of placement and as such, the review focused on kinship and foster care placements only.

\section{Types of participants}

Children and youth under the age of 18 who were removed from the home for abuse, neglect, or other maltreatment and subsequently placed in kinship care.

\section{Types of interventions}

Formal kinship care placements, irrespective of whether the kin caregivers were licensed (paid) or unlicensed (unpaid). Thus, studies that exclusively examine informal or private kinship care arrangements were not considered. Studies were considered if participants experienced other placement types in conjunction with the kinship care intervention. For example, the treatment group may include children for whom kinship care was their first, last, or only placement in out-of-home care. However, these children must have spent the majority (i.e. re-entry more than 50\%) of their total time in out-of-home care in kinship care. 


\section{Types of outcome measures}

Eligible studies must analyze child welfare outcomes in the well-being, permanency, or safety domains. Although caregiver and birth parent outcomes are very relevant, they were not considered in this review because child outcomes are what drive the policy and practice of kinship care. However, these outcomes may mediate or moderate the effect of kinship care on child welfare outcomes and should be explored in future research on the topic. Primary outcomes for the review are behavioral development, mental health, placement stability, and permanency. Secondary outcomes include educational attainment, family relations, service utilization, and re-abuse. The following list of outcome domains is meant to be exhaustive, although the examples in each domain are illustrative of the outcomes to be considered in this review.

\section{Behavioral Development}

Behavior problems, adaptive behaviors

Measured by case records, caregiver, teacher, and self-reports, and standardized instruments (e.g. Child Behavior Checklist)

\section{Mental Health}

Psychiatric illnesses, psychopathological conditions, well-being

Measured by case records, caregiver and self-reports, and standardized instruments

\section{Placement Stability}

Number of placements, re-entry, length of placement

Measured by child welfare administrative databases

\section{Permanency}

Reunification, adoption, guardianship

Measured by child welfare administrative databases

\section{Educational Attainment}

Graduation, grades, test scores

Measured by school records and child welfare administrative databases

\section{Family Relations}

Problem-solving, tolerance, commitment, conflicts

Measured by caregiver and self-reports and standardized instruments

\section{Service Utilization}

Mental health services, foster support groups, family therapy

Measured by medical records, caregiver and self-reports, and child welfare administrative databases 


\section{Re-abuse}

Substantiated abuse, institutional abuse

Measured by child welfare administrative databases

\subsection{SEARCH METHODS FOR IDENTIFICATION OF STUDIES}

\section{Electronic searches}

To identify relevant studies, the following online databases were searched in

February 2007:

Cochrane Library (CENTRAL) searched 2007 (Issue 1)

MEDLINE searched 1966 to February 2007

Campbell Collaboration's Social, Psychological, Educational, and Criminological

Trials Register (C2-SPECTR) searched March 9th 2007

Sociological Abstracts searched 1962 to February 2007

Social Work Abstracts searched 1977 to February 2007

Social Sciences Citation Index (SSCI) searched 1900 to February 17th 2007

Family and Society Studies Worldwide searched 1970 to February 2007

ERIC searched 1966 to February 2007

PsycINFO searched 1872 to January week 52007

ISI Proceedings searched 1990 to February 16th 2007

CINAHL searched 1982 to February week 32007

Applied Social Sciences Index and Abstracts (ASSIA) searched 1987 to February

2007

UMI Dissertation Abstracts International (DAI) searched late 1960s to February 2007

The search strategies used can be found in: Appendix 1, Appendix 2, Appendix 3, Appendix 4, Appendix 5, Appendix 6, Appendix 7, Appendix 8, Appendix 9, Appendix 10, Appendix 11, Appendix 12. Both published and unpublished studies were sought, and there were no language, date, or geographic limitations.

Preliminary searches indicated that a narrowing of the search strategy using a methodological filter resulted in the exclusion of potentially relevant studies so the searches were run without a filter.

\section{Searching other resources}

The most recent volumes of Child Abuse \& Neglect, Children and Youth Services Review, Child Welfare, Research on Social Work Practice, and Families in Society were manually searched. In addition, several authors of studies included in this review were contacted for knowledge of other studies not yet identified. Lastly, the reference lists of published literature reviews were screened for relevant studies. 


\section{$\mathbf{3 \cdot 3}$ \\ DATA COLLECTION AND ANALYSIS}

\section{Selection of studies}

Two reviewers independently read the titles and abstracts of identified articles and reports to select those that described an empirical study of kinship care. A study was obtained if either reviewer believed it is appropriate. Once retrieved, two reviewers used a "keywording" rubric to categorize each study by the type of design, participants, intervention, and outcome measure(s). Two reviewers then determined if each study was eligible for selection based on the aforementioned criteria for considering studies for this review. When consensus regarding selection decisions was not reached, it was resolved through discussion with a third reviewer.

\section{Data extraction and management}

Citations for all selected studies were entered into Reference Manager 11, which is an interactive literature management software package. The citations for included studies then were uploaded into the Cochrane Collaboration's Review Manager 4.2.8 software (RevMan). Outcome data were extracted from studies and entered into RevMan, where it was analyzed in the meta-analyses for this review. The statistical results are presented in both narrative form and in figures and tables. Specifically, forest plots generated from RevMan are used to display effect size estimates and confidence intervals from the meta-analyses. In addition, data from the quality assessment process are presented in a table created in RevMan.

\section{Assessment of risk of bias in included studies}

\section{Quality Assessment}

Existing scales for measuring the quality of controlled trials have not been properly developed, are not well-validated, and are known to give differing (even opposing) ratings of trial quality in systematic reviews (Moher 1999). At present, evidence indicates that "scales should generally not be used to identify trials of apparent low quality or high quality in a given systematic review. Rather, the relevant methodological aspects should be identified a priori and assessed individually" (Juni 2001, p. 45). According to Higgins 2005, "factors that warrant assessment are those related to applicability of findings, validity of individual studies, and certain design characteristics that affect interpretation of results (p. 79). Thus, studies were assessed in regard to the following research quality dimensions: selection bias, performance bias, detection bias, report bias, and attrition bias (Higgins 2005).

\section{Methodological Criteria}

To provide guidelines for assessing the methodological criteria of included studies, a "data extraction" rubric was developed. Two reviewers independently extracted data from each study before coming to consensus on the assessment of quality 
dimensions for each study. The methodological criteria were operationalized as follows:

- Selection Bias: Was group assignment determined randomly or might it have been related to outcomes or the interventions received?

- Performance Bias: Could the services provided have been influenced by something other than the interventions being compared?

- Detection Bias: Were outcomes influenced by anything other than the constructs of interest, including biased assessment or the influence of exposure on detection?

- Report Bias: Were the outcomes, measures, and analyses selected a priori and reported completely? Were participants biased in their recall or response?

- Attrition Bias: Could deviations from protocol, including missing data and dropout, have influenced the results?

\section{Measures of treatment effect}

A standardized mean difference (SMD) effect size was computed for the continuous outcome variables. For this review, a corrected Hedges' g was computed by dividing the difference between group means by the pooled and weighted standard deviation of the groups. Specifically, Hedges' g corrects for a bias (overestimation) that occurs when the uncorrected standardized mean difference effect size is used on small samples. The combined effect size for each outcome was computed as a weighted mean of the effect size for each study, with the weight being the inverse of the square of the standard error. Thus, a study was given greater weight for a larger sample size and more precise measurement, both of which reduce standard error. We computed a 95\% confidence interval for each combined effect size to test for statistical significance; if the confidence interval did not include zero, we rejected the null hypothesis that there is no difference between the group means. Odds ratios (OR) were computed for the dichotomous outcome variables. Based on the assumption of proportional odds, odds ratios can be compared between variables with different distributions, including very rare and more frequent occurrences. Specifically, the odds of an event (e.g. reunification) were calculated for each group by dividing the number of events (i.e. re-entry reunified) by the number of non-events (i.e. re-entry not reunified). An odds ratio then was calculated by dividing the odds of the kinship care group with the odds of the foster care group. In addition, 95\% confidence intervals were computed and reported for the dichotomous effect size estimates.

\section{Unit of analysis issues}

The unit of analysis was children for this review. No attempts were made to adjust for clustering and we were unaware of any such problems including multiple children per family. 


\section{Dealing with missing data}

Although studies with incomplete outcome data (e.g. missing means, standard deviations, sample sizes) were included in the review, they were excluded from the meta-analyses unless the reviewers could calculate an effect size from the available information. When outcome data were missing from an article or report, reasonable attempts were made to retrieve these data from the original researchers. Overall and differential attrition were accounted for in the quality assessment and sensitivity analyses.

\section{Assessment of heterogeneity}

The consistency of results was assessed using the I2 statistic (Higgins 2002; Higgins 2003). If there was evidence of heterogeneity ( $p$ value from test of heterogeneity < o.1 coupled with an I2 value of $25 \%$ or greater), we also considered sources according to pre-specified subgroup and sensitivity analyses (see below).

\section{Assessment of reporting biases}

Reporting biases were assessed and reported in Table 3 .

\section{Data synthesis}

As heterogeneity is to be expected with similar interventions provided under different circumstances and by different providers, the data syntheses used a random effects model. If a study reported multiple effect sizes (e.g. grades, behavior problems), the results were included in the meta-analysis for each outcome. If a study reported effect sizes for multiple samples (e.g. male, female), the results were aggregated for the main effects meta-analyses before being used for the subgroup meta-analyses.

\section{Subgroup analysis and investigation of heterogeneity}

Subgroup analyses were considered to examine different effects of the intervention (if any) by gender, ethnicity, and age at placement.

\section{Sensitivity analysis}

Sensitivity analyses were considered to explore the impact of the quality dimensions on the outcomes of the review. Specifically, the following planned comparisons were considered. Studies that use matching or covariates and studies that do not control for confounders. Studies with outcomes measured by caregiver or teacher reports and studies with outcomes measured by self-reports. Studies with low overall or differential attrition and studies with high overall or differential attrition. 


\section{Results}

\subsection{DESCRIPTION OF STUDIES}

A comprehensive electronic search of the kinship care literature base using 15 online databases yielded 4791citations that matched the search terms (see also Figure 1). The 4791 abstracts for these citations were reviewed and 263 references were identified as meeting the initial criteria of being an empirical study on kinship care. Of the 263 references, 251 were acquired with 12 being unavailable. These 251 articles/reports were then keyworded to determine whether they met the inclusion criteria for the review. As a result, 90 studies were deemed to be potentially appropriate to be included in the review. However, two studies were subsequently categorized as being duplicates and 26 studies did not meet the inclusion criteria upon further review. Thus, 62 eligible studies were included in the evidence base with an overall interrater agreement of $81 \%$ before consensus. As displayed in the Table of Included Studies, outcome data were extracted from these 62 studies with 27 studies reporting bivariate data only, 16 studies reporting multivariate data only, and 19 studies reporting both bivariate and multivariate data.

\section{Excluded Studies}

As displayed in the Table of Excluded Studies, 189 of the 251 available studies were excluded from the review for the following reasons: 81 studies were excluded because there was no formal kinship care group or the kinship care group was not disaggregated from the foster care group; 30 studies were excluded because there was no foster care comparison group or the foster care group was not disaggregated from other out-of-home placement types; 27 studies were excluded because they were non-empirical (e.g. literature reviews); 19 studies were excluded because they were survey, descriptive, or qualitative research designs; 13 studies were excluded because child welfare outcomes were not reported; 10 studies were excluded because they reported on an intervention other than out-of-home placement; five studies were excluded because they were based on an adult sample; and three studies were excluded because the kinship and foster care placements were considered to be permanent.

More than a year after searches were run, a further nine references not identified through electronic searches were supplied by a UK-based peer reviewer of this paper 
for scrutiny (Adams 1969a, Rowe 1984, Millham 1986a, Berridge 1987a, Rowe 1989, Farmer 1991, Kosenen 1993, Hunt 1999a, Sinclair 2000a). Of these, three were excluded (Adams 1969a, Farmer 1991, and Kosenen 1993). Six studies remain awaiting assessment prior to a minor update of this review (Berridge 1987a, Millham 1986a, Hunt 1999a, Rowe 1984, Rowe 1989, Sinclair 2000a).

\section{Studies awaiting assessment}

Three relatively old studies remain awaiting assessment (including Adams 1969a (currently unavailable), Rowe 1984 and Rowe 1989.

\section{Location of Studies}

All but five of the 62 studies were conducted in the U.S. The five international studies were Holtan 2005 conducted in Norway, Mosek 2001 conducted in Israel, Sallnas 2004 conducted in Sweden, Strijker 2003 conducted in the Netherlands, and Tarren-Sweeney 2006 conducted in Australia.

\section{Participants}

As displayed in the Participant Baseline Characteristics Table (Table 5), 52 of the 62 studies reported data for at least one of the following participant characteristics: age at placement, gender, ethnicity, removal reason, or urbanicity.

For age at entry into the specific placement, there was an overall unweighted mean age at placement of 7 years 11 months based on eight studies. Furthermore, seven studies reported a mean age at placement by placement type. For the kinship care group, the unweighted mean age at placement was 4 years 7 months. For the foster care group, the unweighted mean age at placement was 4 years 4 months.

For gender, there were overall unweighted frequencies of $53 \%$ female and $47 \%$ male children based on 38 studies. Furthermore, 20 studies reported gender frequencies by placement type. For the kinship care group, the unweighted frequencies were $50 \%$ female and $50 \%$ male. For the foster care group, the unweighted frequencies were $54 \%$ female and $46 \%$ male.

For ethnicity, there was an overall unweighted frequency of $49 \%$ African-American children based on 37 U.S. studies. Furthermore, 17 studies reported the frequency of African-American children by placement type. For the kinship care group, the unweighted frequency was $63 \%$ African-American. For the foster care group, the unweighted frequency was $56 \%$ African-American. In addition, there was an overall unweighted frequency of 21\% Hispanic children based on 31 studies. Furthermore, 12 studies reported the frequency of Hispanic children by placement type. For both 
the kinship care and foster care groups, the unweighted frequency was $21 \%$ Hispanic.

For removal reason, there was an overall unweighted frequency of $63 \%$ of children removed for neglect based on 24 studies. Furthermore, seven studies reported the frequency of children removed for neglect by placement type. For the kinship care group, the unweighted frequency was $69 \%$ of children removed for neglect. For the foster care group, the unweighted frequency was $66 \%$ of children removed for neglect.

For urbanicity, there was an overall unweighted frequency of $80 \%$ of children from urban settings based on nine studies. In addition, there was an overall unweighted frequency of $17 \%$ of children from rural settings based on four studies. However, no studies reported the urbanicity of children by placement type.

\section{Interventions}

As displayed in the Intervention Characteristics Table (Table 6), all 62 studies reported data for at least one of the following intervention characteristics: caregiver licensure, timing of placement, length of stay, or timing of data collection.

For caregiver licensure, eight studies reported information on whether kinship caregivers were licensed or unlicensed. Specifically, five studies included licensed kinship placements, two studies included unlicensed kinship placements, and one study included both licensed and unlicensed kinship placements.

For the timing of placement, 25 studies reported information on whether children were in their first, last, or only kinship or foster placement. Specifically, the kinship or foster placement was the first in 16 of the studies, the last in six of the studies, the only placement in one study, and either the first or last placement depending on the outcome being measured in two studies.

For length of stay, there was an unweighted mean length of placement of 31.1 months for the kinship care group and 30.1 months for the foster care group based on 11 studies. In addition, there was an unweighted mean length of stay in out-ofhome care of 52.5 months for the kinship care group and 49.5 months for the foster care group based on 10 studies.

For the timing of data collection, 41 studies used a cross-sectional data collection approach while 21 studies used a longitudinal data collection approach. 


\section{Outcome measures}

There were eight outcome categories and 28 specific outcomes considered in this review (including the same outcome measured both dichotomously and continuously). The following narrative contains the definitions and instrumentation used to measure the outcome variables in which bivariate data were extracted for the meta-analyses. The Outcomes Measures Table (Table 7) displays the outcomes and measures for all 62 studies in the review.

\section{Behavioral Development}

The two behavioral development outcomes were behavior problems and adaptive behaviors. Behavior problems were defined dichotomously as the presence or absence of internalizing (e.g. withdrawn, passive) and externalizing (e.g. aggressive, delinquent) problem behaviors and continuously as the level of these behaviors. The continuous outcome was measured by the total problems scale of the Child Behavior Checklist (CBCL) completed by caregivers in seven studies (Davis 2005; Holtan 2005; Jones-Karena 1998; Rudenberg 1991; Strijker 2003; Tarren-Sweeney 2006; Timmer 2004), the Behavior Problems Index completed by caregivers in one study (Brooks 1998), and caregiver reports in one study (Metzger 1997; Surbeck 2000). The dichotomous outcome was measured by case records in two studies (Iglehart 1994; Landsverk 1996). Adaptive behaviors were defined continuously as the level of competence or positive behaviors and were measured by the total competence scale of the CBCL completed by caregivers in two studies (Holtan 2005; Tarren-Sweeney 2006), the adaptive composite score on the Vineland Adaptive Behavior Scales (VABS) completed by caregivers in two studies (Belanger 2002; Jones-Karena 1998), and caregiver reports in one study (Surbeck 2000).

\section{Mental Health}

The two mental health outcomes were psychiatric disorders and well-being. Psychiatric disorders were defined dichotomously by the presence or absence of mental illness and continuously by scores on a measure of psychopathology. The dichotomous outcome was measured by paid claims data in one study (Bilaver 1999), case records in one study (Harris 2003; Iglehart 1994), and the DSM-IV in one study (McMillen 2005). The continuous outcome was measured by the Devereaux Scales of Mental Disorders completed by caregivers in one study (Belanger 2002). Well-being was defined dichotomously by the presence or absence of positive emotional health and continuously by the level of well-being or selfworth. The dichotomous outcome was measured by child self-reports in one study (Wilson 1999), R.C. Monitoring Protocol completed by caseworkers, caregivers, and child in one study (Harris 2003), and caseworker reports in one study (Tompkins 2003). The continuous outcome was measured by the Personal Attribute Inventory for Children completed as a child self-report in one study (Metzger 1997). 


\section{Placement Stability}

The four placement stability outcomes were number of placements, length of placement, placement disruption, and re-entry as measured by secondary data from administrative databases. Number of placements was measured both continuously by the number of out-of-home placements and dichotomously by experiencing either two or fewer or three or more placement settings. The dichotomous outcome was used in four studies (Courtney 1997b; Harris 2003; Metzger 1997; Zimmerman 1998). The continuous outcome was used in two studies (Belanger 2002; Davis 2005). Length of placement was measured continuously by length of stay in the kin or foster placement in five studies (Berrick 1994; Brooks 1998; Cole 2006; Davis 2005; Surbeck 2000) and continuously by length of total stay in out-of-home care in five other studies (Belanger 2002; Clyman 1998; Jenkins 2002; Sivright 2004; Tompkins 2003). It should be noted that longer lengths of stay in placement or in care are considered negative outcomes in the U.S., as reunification within 12 months is the primary permanency goal for children placed in short-term kinship or foster care. Placement disruption was measured dichotomously by whether the kin or foster placement ended without permanency in two studies (Sallnas 2004; Testa 2001). Re-entry was measured dichotomously by whether there was a re-entry to out-of-home care after achieving permanency in one study (Frame 2000).

\section{Permanency}

The four permanency outcomes were reunification, adoption, guardianship, and still in placement. All four outcomes were measured dichotomously by secondary data from administrative databases in ten studies (Barth 1994; Berrick 1999; Mcintosh 2002; Sivright 2004; Smith 2002; Smith 2003; Testa 1999; Testa 2001; Wells 1999; Zimmerman 1998). Reunification was defined as a return home to biological or birth parents after placement in out-of-home care. Adoption was defined as a termination of parental rights with legal custody transferred to adoptive parents (in most cases non-relatives). Guardianship was defined as an allocation of parents rights with legal custody to relative caregivers (in most cases relatives). Still in placement was defined as remaining in either kinship or foster care at the time data were collected for the study.

\section{Educational Attainment}

The three educational attainment outcomes were repeated a grade, graduation, and grade level and all were measured dichotomously. It should be noted that these outcomes are all U.S. measures of educational attainment. Repeated a grade was defined by whether a child had been retained in one or more grades as measured by caregiver reports in four studies (Berrick 1994; Brooks 1998; Metzger 1997; Sripathy 2004). Graduation was defined by whether a child completed high school and was measured by case records in one study (Christopher 1998). Grade level was defined by whether a child's academic performance was below their actual grade level and was measured by child self-reports in one study (Iglehart 1995) and case records in one study (Iglehart 1994). 


\section{Family Relations}

The two family relations outcomes were attachment and conflict. Attachment was defined as perceived level of relatedness or attachment between child and caregiver and was measured continuously by child self-reports in one study (Chapman 2004), the Attachment Q-Sort Version 3 Assessment completed by the child in one study (Chew 1998), caregiver reports in one study (Strijker 2003), Assessment of Interpersonal Relations completed by the child in one study (Davis 2005), and the Child Well-Being Scales completed by caregivers in one study (Surbeck 2000). Attachment was measured dichotomously by the Ainsworth Strange Situation Procedure based on observations of caregiver and child in one study (Cole 2006), case records in one study (Jenkins 2002), and the Offer Self-Image Questionnaire completed by the child in one study (Mosek 2001). Conflict was defined continuously as the level of family functioning as measured by the Index of Family relations completed by caregivers in one study (Berrick 1997).

\section{Service Utilization}

The three service utilization outcomes were mental health services, physician services, and developmental services defined dichotomously as whether a child actually received services (not just referred). Mental health and physician service utilization was measured by paid claims data in one study (Bilaver 1999), caseworker reports in two studies (Metzger 1997; Tompkins 2003), case records in three studies (Jenkins 2002; Scannapieco 1997; Sivright 2004), caregiver reports in two studies (Berrick 1994; Sripathy 2004), and The Young Kids Early Services Assessment (TYKES) in one study (Clyman 1998). Physician services were measured by paid claims data in one study (Bilaver 1999) and the TYKES in one study (Clyman 1998).

\section{Re-abuse}

The two re-abuse outcomes were recurrence of abuse and institutional abuse as measured dichotomously by secondary data from administrative databases. Recurrence of abuse was defined as whether a new substantiated incident of intrafamilial abuse or neglect (i.e. re-entry by birth or biological parent(s) not kin caregiver(s) or foster parent(s)) occurred after a previous substantiated incident and was reported in one study (Fuller 2005). Institutional abuse was defined as whether a substantiated incident of abuse or neglect occurred in an out-of-home placement setting (i.e. re-entry by kin caregiver(s) or foster parent(s) not birth or biological parent(s)) and was reported in two studies (Benedict 1996a; Zuravin 1993).

\subsection{RISK OF BIAS IN INCLUDED STUDIES}

The included studies were assessed on methodological quality in regard to selection bias, performance bias, detection bias, report bias, and attrition bias. Specifically, each study was rated either low risk, moderate risk, or high risk based on two subquestions for each of these areas. As displayed in the Quality Assessment Ratings 
Table (Table 3), the quality assessment indicates that the evidence base contains studies with at least moderate risk in all five categories with the highest risk associated with selection bias and the lowest risk associated with attrition bias.

For selection bias, five studies (Belanger 2002; Clyman 1998; Holtan 2005; Metzger 1997; Testa 2001) were rated low risk, 39 studies were rated moderate risk, and 18 studies were rated high risk. The studies rated high risk did not attempt to equate the kinship care and foster care groups through matching or controlling for covariates AND did not provide evidence on the comparability of the groups on setting (e.g. urbanicity), placement characteristics (e.g. age at placement, removal reason), or child demographics (e.g. gender, ethnicity). The studies rated moderate risk either attempted to equate the groups OR provided evidence on the comparability of the groups. The studies rated low risk attempted to equate the groups AND provided evidence on the comparability of the groups. For example, these studies provided evidence that the groups were comparable at baseline in regard to placement history, visits to biological parents, and caregiver characteristics (e.g., family composition, age, education). The primary reasons that studies were assessed to have moderate or high risk for selection bias were the lack of equating procedures and the non-reporting of placement and demographic data.

For performance bias, four studies (Berrick 1997; Holtan 2005; Metzger 1997; Sivright 2004) were rated low risk, 54 were rated moderate risk, and four were rated high risk. In the studies that were rated high risk, the kinship care and foster care groups experienced differential exposure to the intervention (e.g. length of stay) AND received differential services during placement (e.g. caseworker contact). In the studies that were rated moderate risk, the groups either experienced differential exposure OR received differential services. In the studies that were rated low risk, the groups did not experience differential exposure AND did not receive differential services. The primary reasons that studies were assessed to have moderate or high risk for performance bias were uncertainty regarding both the length of stay and receipt of services during placement.

For detection bias, four studies (Benedict 1996a; Jenkins 2002; Scannapieco 1997; Zuravin 1993) were rated low risk, 54 were rated moderate risk, and four were rated high risk. In the studies rated high risk, the kinship care and foster care groups were not defined in the same way (e.g. caregiver licensure, caregiver characteristics) AND there was evidence of biased assessment resulting from the type of placement (e.g. caregiver reports only). In the studies rated moderate risk, the groups were not defined in the same way OR there was evidence of biased assessment. In the studies rated low risk, the groups were defined in the same way AND there was no evidence of biased assessment. The primary reasons that studies were assessed to have moderate or high risk for detection bias were uncertainty in how the groups were defined and the use of only caregiver or self-reports to measure the outcome. 
Although biased assessment is not necessarily due to the type of placement, it may differentially impact the detection of a placement's effect on child welfare outcomes.

For report bias, 19 studies were rated low risk and 43 studies were rated moderate risk. In the studies rated moderate risk, the instrumentation used to measure the outcomes was specified completely (e.g. data collection procedures) OR reliability and/or validity information was reported for the instrumentation. In the studies rated low risk, the instrumentation was completely specified AND reliability and/or validity information was reported. The primary reason that studies were assessed to have moderate risk for report bias was the lack of reliability and/or validity information.

For attrition bias, 25 studies were rated low risk, 35 studies were rated moderate risk, and two studies were rated high risk. In the studies rated high risk, all subjects were not accounted for in the reporting of results (e.g. low response rate, missing outcome data) AND attrition could have influenced the results (e.g. significant difference between participants and nonparticipants). In the studies rated moderate risk, all subjects were not accounted for OR attrition could have influenced the results. In the studies rated low risk, all subjects were accounted for AND attrition could not have influenced the results. The primary reason that studies were assessed to have moderate or high risk for attrition bias was the loss of subjects due to missing outcome data.

\subsection{EFFECTS OF INTERVENTIONS}

\section{Meta-analyses}

There were sufficient data for meta-analysis for 16 of the 28 outcomes in the review, as only outcomes with three or more studies were considered for effect size calculation. As a result, meta-analyses were generated for all outcome categories except for re-abuse. The results for these 16 outcomes are reported in regard to the statistical significance of the effect, the direction and magnitude of the effect size, the 95\% confidence interval around the effect size estimate, and the evidence of heterogeneity for the individual effect sizes. The effect sizes were drawn exclusively from the studies reporting bivariate data, and thus do not reflect adjustment by covariates. It should be noted that all SMD effect sizes that are negative indicate better outcomes for the kinship care group, while all OR effect sizes that are less than 1.0 also indicate better outcomes for the kinship care group.

\section{Behavioral Development}

There was a statistically significant, small overall effect size for the 10 studies (Brooks 1998; Davis 2005; Holtan 2005; Jones-Karena 1998; Metzger 1997; Rudenberg 1991; Strijker 2003; Surbeck 2000; Tarren-Sweeney 2006; Timmer 2004) that reported sufficient bivariate data to generate effect size estimates for 
behavior problems. Specifically, the overall effect size estimate was $\mathrm{g}=-.24$ with a confidence interval of -.13 to -.35 (see Analysis 1.1). Thus, children in kinship care had lower reported levels of internalizing and externalizing behavior problems than did children in foster care. The test of heterogeneity was not significant for this outcome ( $\mathrm{p}=.16$; $\mathrm{I} 2=31.1 \%)$. There was a statistically significant overall effect size for the five studies (Belanger 2002; Holtan 2005; Jones-Karena 1998; Surbeck 2000; Tarren-Sweeney 2006) that reported sufficient bivariate data to generate effect size estimates for adaptive behaviors. Specifically, the overall effect size estimate was $g=-.45$ with a confidence interval of -.19 to -.70 (see Analysis 1.2). Thus, children in kinship care had higher reported levels of competence than did children in foster care. The test of heterogeneity was significant for this outcome ( $p$ $=.01 ; \mathrm{I} 2=68.4 \%)$.

\section{Mental Health}

There was a statistically significant overall effect size for the four studies (Bilaver 1999; Harris 2003; Iglehart 1994; McMillen 2005) that reported sufficient bivariate data to generate effect size estimates for psychiatric disorders. Specifically, the overall effect size estimate was OR $=.46$ with a confidence interval of .44 to .49 (see Analysis 2.1). Thus, children in foster care were 2.2 times more likely than were children in kinship care to experience mental illness. The test of heterogeneity was not significant for this outcome $(\mathrm{p}=.93 ; \mathrm{I} 2=0.0 \%)$. There was a statistically significant overall effect size for the three studies (Harris 2003; Tompkins 2003; Wilson 1999) that reported sufficient bivariate data to generate effect size estimates for well-being. Specifically, the overall effect size estimate was reported OR $=.52$ with a confidence interval of .51 to .53 (see Analysis 2.3). Thus, children in kinship care were 1.9 times more likely than were children in foster care to report positive emotional health. The test of heterogeneity was not significant for this outcome $(\mathrm{p}=$ $.95 ;$ I 2 = 0.0\%).

\section{Placement Stability}

There was a statistically significant overall effect size for the four studies (Courtney 1997b; Harris 2003; Metzger 1997; Zimmerman 1998) that reported sufficient bivariate data to generate effect size estimates for placement settings. Specifically, the overall effect size estimate was $\mathrm{OR}=.36$ with a confidence interval of .27 to .49 (see Analysis 3.1). Thus, children in foster care were 2.6 times more likely than were children in kinship care to experience three or more placement settings. The test of heterogeneity was not significant for this outcome ( $\mathrm{p}=.31$; I2 = 16.8\%).

There were five studies (Berrick 1994; Brooks 1998; Cole 2006; Davis 2005; Surbeck 2000) that reported sufficient bivariate data to generate effect size estimates for length of placement. Although the overall effect size was in favor of children in foster care, the effect was not statistically significant. Specifically, the overall effect size estimate was $g=.86$ with a confidence interval of -.98 to 2.70 (see Analysis 3.3 ). 
However, the analysis could not rule out zero as a likely population value. The test of heterogeneity was significant for this outcome $(p<.001$; I2 = 99.4\%).

There were five studies (Belanger 2002; Clyman 1998; Jenkins 2002; Sivright 2004; Tompkins 2003) that reported sufficient bivariate data to generate effect size estimates for length of stay in out-of-home care. Although the overall effect size was in favor of children in foster care, the effect was not statistically significant. Specifically, the overall effect size estimate was $g=.21$ with a confidence interval of -.07 to .48 (see Analysis 3.6). However, the analysis could not rule out zero as a likely population value. The test of heterogeneity was significant for this outcome ( $\mathrm{p}<.001 ; \mathrm{I} 2$ = 78.8\%).

\section{Permanency}

There were seven studies (Berrick 1999; Mcintosh 2002; Smith 2002; Testa 1999; Testa 2001; Wells 1999; Zimmerman 1998) that reported sufficient bivariate data to generate effect size estimates for reunification. Although the overall effect size was in favor of children in foster care, the effect was not statistically significant. Specifically, the overall effect size estimate was $\mathrm{OR}=1.13$ with a confidence interval of .92 to 1.41 (see Analysis 4.1). However, the analysis could not rule out zero as a likely population value. The test of heterogeneity was significant for this outcome $(\mathrm{p}<.001 ; \mathrm{I} 2=77.8 \%)$.

There was a statistically significant overall effect size for the six studies (Barth 1994; Berrick 1999; Smith 2002; Testa 1999; Testa 2001; Zimmerman 1998) that reported sufficient bivariate data to generate effect size estimates for adoption. Specifically, the overall effect size estimate was $\mathrm{OR}=2.50$ with a confidence interval of 1.05 to 5.94 (see Analysis 4.2). Thus, children in foster care were more likely to be adopted than were children in kinship care. The test of heterogeneity was significant for this outcome ( $<$.001; I2 = 98.5\%).

There was a statistically significant overall effect size for the four studies (Berrick 1999; Testa 1999; Testa 2001; Zimmerman 1998) that reported sufficient bivariate data to generate effect size estimates for guardianship. Specifically, the overall effect size estimate was $\mathrm{OR}=.26$ with a confidence interval of .10 to .72 (see Analysis 4.3). Thus, children in kinship care were more likely to have relatives assume legal custody than were children in foster care. The test of heterogeneity was significant for this outcome ( $<$.001; I2 = 93.1\%).

There was a statistically significant overall effect size for the seven studies (Barth 1994; Berrick 1999; Sivright 2004; Smith 2002; Smith 2003; Testa 2001; Zimmerman 1998) that reported sufficient bivariate data to generate effect size estimates for the still in placement outcome. Specifically, the overall effect size estimate was $\mathrm{OR}=2.24$ with a confidence interval of 1.66 to 3.03 (see Analysis 4.4). Thus, children in kinship care were more likely to still be in care than were children 
in foster care. The test of heterogeneity was significant for this outcome ( $<$.oo1; I2 $=88.0 \%)$.

\section{Educational Attainment}

There were four studies (Berrick 1994; Brooks 1998; Metzger 1997; Sripathy 2004) that reported sufficient bivariate data to generate effect size estimates for the repeated a grade outcome. Although the overall effect size was in favor of children in kinship care, the effect was not statistically significant. Specifically, the overall effect size estimate was $\mathrm{OR}=.67$ with a confidence interval of .43 to 1.05 (see Analysis $5.3)$. However, the analysis could not rule out zero as a likely population value. The test of heterogeneity was not significant for this outcome $(\mathrm{p}=.10$; I2 $=51.9 \%)$.

\section{Family Relations}

There were five studies (Chapman 2004; Chew 1998; Davis 2005; Strijker 2003; Surbeck 2000) that reported sufficient bivariate data to generate effect size estimates for the continuous attachment outcome. Although the overall effect size was in favor of children in kinship care, the effect was not statistically significant. Specifically, the overall effect size estimate was $g=-.01$ with a confidence interval of -.30 to .28 (see Analysis 6.1). However, the analysis could not rule out zero as a likely population value. The test of heterogeneity was significant for this outcome $(\mathrm{p}=.09 ; \mathrm{I} 2=50.2 \%)$.

There were three studies (Cole 2006; Jenkins 2002; Mosek 2001) that reported sufficient bivariate data to generate effect size estimates for the dichotomous attachment outcome. Although the overall effect size was in favor of children in kinship care, the effect was not statistically significant. Specifically, the overall effect size estimate was $\mathrm{OR}=.88$ with a confidence interval of .33 to 2.30 (see Analysis 6.3). However, the analysis could not rule out zero as a likely population value. The test of heterogeneity was not significant for this outcome ( $p=.12$; I2 = 52.7\%).

\section{Service Utilization}

There was a statistically significant overall effect size for the nine studies (Berrick 1994; Bilaver 1999; Clyman 1998; Jenkins 2002; Metzger 1997; Scannapieco 1997; Sivright 2004; Sripathy 2004; Tompkins 2003) that reported sufficient bivariate data to generate effect size estimates for mental health service utilization. Specifically, the overall effect size estimate was $\mathrm{OR}=1.69$ with a confidence interval of 1.18 to 2.42 (see Analysis 7.1). Thus, children in foster care were more likely to receive mental health services than were children in kinship care. The test of heterogeneity was significant for this outcome ( $p<.001$; I $2=97.2 \%)$.

There were four studies (Bilaver 1999; Clyman 1998; Scannapieco 1997; Tompkins 2003) that reported sufficient bivariate data to generate effect size estimates for physician service utilization. Although the overall effect size was in favor of children in foster care, the effect was not statistically significant. Specifically, the overall 
effect size estimate was $\mathrm{OR}=2.93$ with a confidence interval of .46 to 18.59 (see Analysis 7.3). However, the analysis could not rule out zero as a likely population value. The test of heterogeneity was significant for this outcome $(\mathrm{p}<.001 ; \mathrm{I} 2=$ $99.3 \%)$.

\section{Multivariate analyses}

As studies that reported multivariate data controlled for covariates such as age at placement, gender, ethnicity, socioeconomic status, geographic region, behavior and health problems, placement reason and history, and caregiver variables, they potentially provide a stronger level of evidence regarding the effect of kinship care on child welfare outcomes. Thus, results from the weaker quasi-experimental designs comprising the meta-analytical data could also be considered stronger evidence if corroborated by the multivariate results which are summarized in the Outcomes for Studies with Multivariate Analysis Table (Table 1). It should be noted that some studies reported both bivariate and multivariate data and were included in both analyses.

Overall, the multivariate data generally support the results generated from the metaanalyses. For example, two studies reporting multivariate behavior problems data (Bennett 2000; Holtan 2005) found that children in kinship care had significantly lower CBCL scores than did children in foster care. Surbeck 2000 and Zima 2000 did not find a significant difference between the groups and did not report the direction of the effect. Furthermore, three studies reporting multivariate adaptive behaviors data (Belanger 2002; Bennett 2000; Brooks 1998) found that children in kinship care had significantly greater adaptive behaviors than did children in foster care. Again, Zima 2000 did not find a significant difference between the groups on this outcome and did not report the direction of the effect. Three studies reporting multivariate data on mental health service utilization (Clyman 1998; Leslie 2000a; McMillen 2004) found that children in foster care were significantly more likely to utilize services than were children in kinship care. For mental health, one study reporting multivariate data (Metzger 1997) found that children in kinship care had significantly greater well-being than did children in foster care.

The greatest amount of multivariate data was reported for the permanency outcomes. Similar to the nonsignificant meta-analysis results for reunification, the findings from the nine studies reporting multivariate data also were inconclusive. Specifically, three studies (Berrick 1999; Courtney 1996a; Grogan-Kaylor 2000) found that children in kinship care were more likely to reunify and two studies (Connell 2006a; Courtney 1996b) found that children in foster care were more likely to reunify. Courtney 1997a and Frame 2002 found no significant difference between the groups on reunification and did not report the direction of the effect. Wells 1999 and Zimmerman 1998 also found no significant difference between the groups on reunification, but reported that children in foster care reunified at a lower rate. As 
for adoption, two studies reporting multivariate data (Barth 1994; Courtney 1996b) found that children in foster care were significantly more likely to be adopted than were children in kinship care, although Courtney 1996a found that children in kinship care were more likely to be adopted. Furthermore, Connell 2006a found no significant difference on adoption and reported an identical risk ratio for both groups. Lastly, two studies reporting multivariate data (Berrick 1999; Smith 2003) found that children in foster care were significantly less likely to still be in care than were children in kinship care.

The studies reporting multivariate data also provided evidence for some of the outcomes that had insufficient data for effect size calculation. For example, the most compelling evidence from the multivariate analyses was for re-entry, in that all seven studies (Berrick 1999; Courtney 1995; Courtney 1997a; Frame 2000; Frame 2002; Jonson-Reid 2003; Wells 1999) reported that children in kinship care were significantly less likely to re-enter care than were children placed in foster care. Furthermore, all three studies that reported multivariate placement disruption data (Chamberlain 2006; Connell 2006b; Testa 2001) found that children in kinship care were less likely to disrupt from placement than were children in foster care. For the safety outcomes, two studies reporting multivariate data (Benedict 1996a; Zuravin 1993) found that children in kinship care were less likely to experience institutional abuse than were children in foster care. The multivariate results were inconclusive for recurrence of abuse, as Jonson-Reid 2003 found that children in kinship care were less likely to experience recurrence of abuse than were children in foster care, while Fuller 2005 found that children in kinship care were more likely to experience recurrence of abuse than were children in foster care.

\section{Bivariate analyses}

As summarized in the Outcomes for Studies with Bivariate Analysis Table (Table 2), there were several studies that reported findings from bivariate analyses but did not report sufficient information for effect size calculation. Typically, these studies reported nonsignificant findings in the narrative but did not include the relevant data in a table. For example, two studies (Landsverk 1996; Sripathy 2004) found no difference between children in kinship care and foster care on the level of behavior problems as measured by the CBCL. However, Berrick 1994 confirmed the results from the meta-analysis and multivariate analysis in that children in kinship care had significantly lower scores on the total problems scale of the CBCL than did children in foster care. As for adaptive behaviors, Sripathy 2004 found no difference between children in kinship care and foster care on the level of adaptive behaviors as measured by the CBCL. For length of placement, two studies (Scannapieco 1997; Zimmerman 1998) found that children in foster care had significantly shorter lengths of stay than did children in kinship care, while Metzger 1997 found that children in kinship care had significantly lower lengths of stay than did children in 
foster care. Lastly, Zimmerman 1998 found no difference between the groups on reentry rates.

\section{Sensitivity analyses}

Sensitivity analyses comparing studies with high attrition and low attrition were planned but were not conducted because attrition rates could not be accurately determined for the quasiexperimental studies included in the review. Specifically, all of these studies were posttest only, so there often was incomplete data on how many children were originally placed in kinship or foster care and no pre-measures to indicate how many children "dropped out" of the study by the time of the postmeasures data collection. There were missing data in some of the studies, in that multiple measures had different sample sizes, presumably because data were either not available from case files or not collected. However, the missing data is presumed to be missing at random, thus no sensitivity analysis is warranted. Furthermore, sensitivity analyses comparing studies with low and high risk for attrition bias were not conducted because only two studies were rated high risk.

Sensitivity analyses comparing studies with child self-reports and parent/teacher/caregiver reports were planned for the review, but were not conducted because of the lack of such comparisons for the included outcomes. For example, there were four studies that measured well-being by child self-reports, but only one study that also measured it using caregiver reports. Furthermore, there was only one study each measuring psychiatric illness, family relations, and behavior problems by child self-report. Lastly, three studies used child selfreports for educational attainment outcomes, but there was only one each for test scores, graduation, and grade level; thus comparisons were not possible with the studies that used other measures.

Sensitivity analyses comparing studies that controlled for confounders with those that did not was not possible using statistical techniques because of differences in the type of data reported. Specifically, the studies that controlled for confounders used multivariate analyses rather than matching (except for Rudenberg 1991; Testa 2001). As such, much of the multivariate data was reported as correlation and beta coefficients or odds and risk ratios. Thus, these data could not be used in the metaanalyses to generate multivariate effect sizes to compare with the bivariate data effect sizes. However, we employed vote counting for the multivariate studies to provide some comparison with the results from the bivariate studies. In addition, sensitivity analyses comparing studies with low and high risk for selection bias were not conducted because only five studies were rated low risk and no more than two studies shared similar outcomes. 


\section{Subgroup analyses}

There were insufficient data to examine different effects of the intervention by gender, ethnicity, and age at placement. Specifically, only Holtan 2005 reported outcome data by gender for each placement type, only Smith 2002 reported outcome data by ethnicity for each placement type, and no studies reported outcome data by age at placement for each placement type. 


\section{Discussion}

\subsection{SUMMARY OF MAIN RESULTS}

Based on a preponderance of the available evidence, it appears that children in kinship care experience better outcomes in regard to behavior problems, adaptive behaviors, psychiatric disorders, well-being, placement stability, and guardianship than do children in foster care. Furthermore, there was no detectable difference between the groups on reunification, length of stay, family relations, or educational attainment. However, children placed with kin are less likely to achieve adoption and utilize mental health services while being more likely to still be in placement than are children in foster care. The multivariate results generally support these findings while indicating that children in kinship care are less likely to re-enter outof-home care or have a disrupted placement than are children in foster care. However, these conclusions are tempered by the pronounced methodological and design weaknesses of the included studies and particularly the absence of conclusive evidence of the comparability of groups. It is clear that researchers and practitioners must do better to mitigate the biases that cloud the study of kinship care.

Although this review supports the practice of treating kinship care as a viable out-ofhome placement option for children removed from the home for maltreatment, policies mandating kinship placements may not always be in the best interest of children and families. Professional judgment from child welfare practitioners also should be used to assess the individual needs of children and the ability of kin caregivers to attend to these needs.

\subsection{OVERALL COMPLETENESS AND APPLICABILITY OF EVIDENCE}

Because all of the effect sizes are small to medium in magnitude, the findings generated from this review may have limited practical consequences. However, the applicability of the evidence is still worth considering, especially for the key outcomes. For example, the lack of a baseline measurement of initial behavioral functioning makes ambiguous the conclusion that children in foster care have lower levels of current behavioral functioning. Furthermore, caregiver reports may be biased because foster parents have more incentive to report behavioral and mental 
health issues, whereas relatives are more apt to view the behavior as acceptable and thus less likely to report it as problematic.

The mixed findings for the permanency outcomes could be interpreted in the context that long-term kinship care arrangements satisfy the definition of permanency in many countries, as kinship caregivers are allocated the parental rights for a child. Thus, an undesirable outcome (i.e. re-entry remaining in care) might actually be desirable if the kinship care placement is considered to be safe and stable. Adoption and guardianship are secondary permanency goals, which are considered only after reunification has been ruled out. Furthermore, these permanency outcomes are fundamentally dependent on the public and legal policy of individual countries. For example, adoption is not a viable permanency option in many countries outside of the U.S. including Australia, Israel, Netherlands, and the Nordic nations.

The commonly held idea that foster parents are more "system involved" may explain the greater propensity for children in foster care to receive mental health services. Furthermore, the training and supervision of foster parents may contribute to the higher identification of mental health problems, and as such contribute to higher levels of service utilization. The lower licensure rate for kin caregivers may be another factor in the unequal receipt of services for children in kinship care. However, the greater likelihood for children in foster care to utilize mental health services may have less to do with the type of placement and more to do with these children having a greater need for services.

\subsection{QUALITY OF THE EVIDENCE}

The major limitation encountered in this systematic review is the weak standing of quantitative research on kinship care (Cuddeback 2004). Specifically, the "differences between the children who enter kinship care and those who enter nonkinship care" lead to a lack of confidence regarding the comparability of groups and the subsequent lack of control over contaminating events such as family preservation services (Barth 2008, p. 218). In general, the included studies also have moderate to high risks of performance, detection, report, and attrition bias, which compromise the tenability of the findings from the systematic review.

Another concern regarding the quality of evidence is the potential misalignment between the intervention and child welfare outcomes, in that the fullest representation of the effects of kinship care has yet to be truly measured (Cuddeback 2004). When compared to traditional foster care, in which the relationship between foster parents and the "system" is more standardized, the effect of kinship care may be more difficult to detect. For example, there seemingly is a lack of implementation fidelity within and across countries in regard to kinship care implementation. Furthermore, kinship placements, especially with unlicensed caregivers, are often more private and out of the control of child welfare agencies than are foster 
placements. The concepts, terminology, and outcomes typically ascribed to out-ofhome care may not always be appropriate for kinship placements. As a result of these limitations, it is more appropriate to research kinship care after it has been fully and consistently integrated into the fabric of child welfare policy and practice.

\subsection{POTENTIAL BIASES IN THE REVIEW PROCESS}

One potential bias in the review process is that the usefulness of the meta-analysis results is weakened by challenges confronted during the effect size calculations. Specifically, the heterogeneity statistic was significant for 10 of the 16 outcomes, which indicates that the effect sizes were not always consistent within the same construct. In addition, bivariate data were not reported in every study, which restricted the meta-analysis of some outcomes to the bare minimum of three studies and eliminated other outcomes from consideration. Another potential bias is that many studies analyzed a small sample of children, while others utilized a much larger data set. As a result, studies with large sample sizes essentially eliminated the effects from studies with small sample sizes for certain outcomes (e.g. psychiatric disorders, well-being, placement settings). In addition, publication bias is always a concern with systematic reviews. It was not plausible to investigate the presence of publication bias in this review because the results were widely distributed across so many studies. However, the review included unpublished reports, dissertations, and theses, along with many studies that reported nonsignificant results.

\subsection{AGREEMENTS AND DISAGREEMENTS WITH OTHER STUDIES OR REVIEWS}

The results of this review are in strong agreement with the "substantive synthesis of research" conducted by Cuddeback 2004. 


\section{Authors' Conclusions}

\subsection{IMPLICATIONS FOR PRACTICE}

Although the implications of this review depend on how individual countries interpret the results, several recommendations for social work professionals and policymakers did emerge. If the goal of kinship care is to enhance the behavioral development, mental health functioning, and placement stability of children, then the evidence base is supportive. However, the findings from the review do not support implementing kinship care solely to increase the permanency rates and service utilization of children in out-of-home care. The primary implication for practitioners to consider is whether kinship placements would be even more effective with increased levels of caseworker involvement and service delivery (Geen 2000). However, the potential benefits of greater financial and therapeutic support must be weighed against the independence that some kin caregivers demand. Relatedly, the main implications for policymakers is whether licensing standards should be required for kin caregivers (Geen 2000), and whether additional financial resources should be made available to these providers (Hornby 1996).

On the other hand, there may be a cost-effectiveness component to placing children with relatives in light of the comparable well-being and permanency outcomes and lower payments and fewer services offered to kin caregivers. As such, this could play an important role in how child welfare agencies view their current approach to kinship care. That being said, foster care should continue to be an essential out-ofhome care option, as children in these placements also experience positive outcomes and appropriate kinship placements are not always available.

\subsection{IMPLICATIONS FOR RESEARCH}

To address the major limitations of research on kinship care, there is a demand for studies that employ generalizable samples, equivalent groups, and repeated measurements (Berrick 1994). Cuddeback 2004 advocates for longitudinal designs to investigate the outcomes of children over time, the development of psychometrically sound instruments of family and child functioning that allow for more reliable comparisons across groups and studies, and greater emphasis on controlling and understanding selection bias through the use of emerging statistical 
models. Furthermore, the duration effect or the relationship between length of stay in out-of-home care and child welfare outcomes should be explored in greater depth. There also is a need to disaggregate the effects of kinship care across important subgroups of target participants, settings, and intervention variations. For example, there are few studies that reliably measure the effect of kinship care on caregiver outcomes (Gibbs 2000).

As for other topics, Testa 1992 calls for research on the financial implications of kin caregivers becoming licensed, while Cuddeback 2004 recommends studies that examine the relationship between certification and the provision of services to kin caregivers. Studies that focus on the educational outcomes of children in kinship care is certainly warranted, as education is essential to effectively integrating into adult life. In addition, research on informal and voluntary kinship care arrangements should be a top priority for social work researchers.

Qualitative research that explores the underlying dynamics of kinship care along with the factors associated with positive outcomes is a natural outgrowth of this systematic review. Specifically, investigating the lived experiences of different types of kin caregivers (e.g. grandparents, other relatives, family friends) would greatly enhance our understanding of this placement option.

As research on this topic is predominantly U.S. based, studies from other countries are sorely needed, especially as kinship care is increasing in popularity elsewhere in the western world. For example, the different permanency goals should be examined in greater depth to determine which outcome offers greater practical permanency to children removed from the home.

For kinship care to remain a viable option in the social work repertoire, researchers must work more closely with practitioners to design, implement, and disseminate innovative studies of the intervention. For example, new predictor variables and outcome measures should be included in data collection instruments to facilitate richer analyses on the effect of kinship care.

Lastly, the Methods for Future Updates Table (Table 4) displays methods such as sensitivity and subgroup analyses that were not conducted in this review but should be included in future updates. 


\section{Acknowledgements}

Thank you to the Nordic Campbell Center, Danish National Institute of Social Research for funding this review. Thank you to Trine Bak Nyby, Krystyna Kowalski, Jane Dennis, Geraldine Macdonald, and Julia Littell for their timely feedback and generous support during the writing of the protocol and review. Thank you to Jo Abbott, Trial Search Coordinator for the Cochrane DPLPG, and Merinda McLure, Applied Human Sciences Librarian at Colorado State University (CSU), for assistance in developing and executing the search strategy for the review. Thank you to Toby Lasserson (Cochrane Airways Group, London, UK), Celia Almeida (Cochrane DPLPG, Bristol, UK), Soyna Curtis, and Professor Jelena Marinkovic and Dr. Jelena Marinkovic both from University of Belgrade, Serbia for translating the foreign language articles for the review. Thank you to Jeff Valentine and the content reviewers along with Brian Cobb and Jeffrey Gliner of CSU for their helpful suggestions. Special thanks to Keri Batchelder of CSU for her assistance in acquiring the studies, extracting data, and conducting quality assessments for the review. Thank you to Frank Ainsworth, Marianne Berry, Morten Blekesaune, and Amy Holtan, as this protocol incorporates elements of their jointly registered Cochrane and Campbell Collaboration protocol prepared in 2004 on the same topic. 


\section{Characteristics of studies}

\subsection{CHARACTERISTICS OF INCLUDED STUDIES}

Barth 1994

\begin{tabular}{ll}
\hline Methods & $\begin{array}{l}\text { Multivariate effect sizes adjusted using covariates for age, facility of initial } \\
\text { placement, ethnicity, AFDC-eligibility status and preplacement preventive } \\
\text { services }\end{array}$ \\
\hline Participants & Kinship $n=526$ \\
& Foster $n=1,324$ \\
& $\begin{array}{l}\text { Local sample of all children entering foster care in California in } 1988 \text { and } \\
1989 \text { who were adopted by } 1991 \text { are compared to a random sample of all } \\
\text { children entering care during the same time period. }\end{array}$ \\
\hline Interventions & See Table 6 \\
\hline Outcomes & Permanency - Adoption, Still in Placement \\
\hline Notes &
\end{tabular}

Belanger 2002

\begin{tabular}{ll}
\hline Methods & $\begin{array}{l}\text { Multivariate effect sizes adjusted using covariates for home index variables } \\
\text { and temperament match index variables }\end{array}$ \\
\hline Participants & $\begin{array}{l}\text { Kinship } \mathrm{n}=22 \\
\text { Foster } \mathrm{n}=39 \\
\text { Local sample drawn from Jewish Child Care Association in New York }\end{array}$ \\
\hline Interventions & See Table 6 \\
\hline Outcomes & $\begin{array}{l}\text { Mental Health - Psychiatric Disorders } \\
\text { Behavioral Development - Adaptive Behaviors } \\
\text { Placement Stability - Length of Stay }(\mathrm{OOH}), \text { Number of Placements }\end{array}$ \\
\hline Notes & \\
\hline
\end{tabular}

Benedict 1996a

\begin{tabular}{ll}
\hline Methods & $\begin{array}{l}\text { Multivariate effect sizes adjusted using covariates for child gender, age at } \\
\text { placement, placement reason, placement type, indicators of health problems } \\
\text { prior to placement, and indicators of health problems during placement }\end{array}$ \\
\hline Participants & Kinship $n=90$ \\
& Foster $n=180$ \\
\hline
\end{tabular}


Local sample of children with substantiated maltreatment reports in

Baltimore

Comparison sample compiled of one child from each home without a maltreatment report during the same time period.

\begin{tabular}{ll}
\hline Interventions & See Table 6 \\
\hline Outcomes & Re-Abuse - Institutional Abuse \\
\hline Notes & \\
\hline
\end{tabular}

\section{Bennett 2000}

\begin{tabular}{ll}
\hline Methods & $\begin{array}{l}\text { Multivariate effect sizes adjusted using covariates for placement history } \\
\text { variables and foster parent perception variables }\end{array}$ \\
\hline Participants & $\begin{array}{l}\text { Kinship } n=28 \\
\text { Foster } n=71 \\
\text { Foster children between the ages of } 2 \text { and } 18 \text { years who were administered } \\
\text { psychological testing as part of the pre-adoption procedure; subset of a } \\
\text { larger database of children (of an outpatient clinic at a children's hospital in a } \\
\text { large city in western New York) who were freed for adoption between 1994- } \\
\text { 1999 }\end{array}$ \\
\hline Interventions & See Table 6 \\
\hline Outcomes & Behavioral Development - Behavior Problems, Adaptive Behaviors \\
\hline Notes & \\
\hline
\end{tabular}

Berrick 1994

\begin{tabular}{ll}
\hline Methods & $\begin{array}{l}\text { No control for confounders } \\
\text { Demographic comparison using gender and ethnicity }\end{array}$ \\
\hline Participants & Kinship $n=246$ \\
& $\begin{array}{l}\text { Foster } n=354 \\
\text { Drawn from the University of California at Berkeley-Foster Care Database } \\
\end{array}$ \\
& (UCB-FCD) which contains information on all children in foster care in \\
& California from January 1988 through the present time of the study - 1991 \\
\hline Interventions & See Table 6 \\
\hline Outcomes & Placement Stability - Length of Placement \\
& Service Utilization - Mental Health Services \\
& Educational Attainment - Repeated a Grade \\
\hline Notes & \\
\hline
\end{tabular}

Berrick 1997

\begin{tabular}{ll}
\hline Methods & No control for confounders \\
\hline Participants & Kinship $n=28$ \\
& $\begin{array}{l}\text { Foster } n=33 \\
\text { Local sample randomly drawn from one county in California. }\end{array}$ \\
\hline Interventions & See Table 6 \\
\hline Outcomes & Family Relations - Conflict
\end{tabular}


Notes

Berrick 1999

\begin{tabular}{ll}
\hline Methods & Multivariate effect sizes adjusted using covariates for ethnicity \\
\hline Participants & Kinship $n=32,946$ (permanency outcomes) \\
& Foster $n=32,586$ (permanency outcomes) \\
& Kinship $n=52,573$ (placement stability outcome) \\
& Foster $n=41,286$ (placement stability outcome) \\
& Sample includes all children entering care in California for the first time in \\
& $1989-1991$ \\
\hline Interventions & See Table 6 \\
\hline Outcomes & Permanency - Reunification, Adoption, Guardianship, Still in Placement \\
& Placement Stability - re-entry \\
\hline Notes &
\end{tabular}

Bilaver 1999

\begin{tabular}{ll}
\hline Methods & $\begin{array}{l}\text { No control for confounders for kinship-foster comparison } \\
\text { No demographic comparison }\end{array}$ \\
\hline Participants & $\begin{array}{l}\text { Kinship } n=14,106 \\
\text { Foster } n=33,649 \\
\text { Local sample drawn from all Medicaid eligible children in 1994-1995 as well } \\
\text { as all children in foster care during that same period }\end{array}$ \\
\hline Interventions & See Table 6 \\
\hline Outcomes & Mental Health - Psychiatric Disorders \\
& $\begin{array}{l}\text { Service Utilization - Mental Health Services, Developmental Services, } \\
\text { Physician Services }\end{array}$ \\
\hline Notes &
\end{tabular}

Brooks 1998

\begin{tabular}{|c|c|}
\hline Methods & $\begin{array}{l}\text { Multivariate effect sizes adjusted using covariates for age } \\
\text { Demographic comparison using gender, ethnicity, age, child health, and } \\
\text { placement history }\end{array}$ \\
\hline Participants & $\begin{array}{l}\text { Kinship } n=242 \\
\text { Foster } n=336 \\
\text { Drawn from the University of California at Berkeley-California Services } \\
\text { Archive (UCB-CSA) which contains information on all children in foster care } \\
\text { in California from January } 1988 \text { through the present time of the study }\end{array}$ \\
\hline Interventions & See Table 6 \\
\hline Outcomes & $\begin{array}{l}\text { Educational Attainment - Repeated a Grade } \\
\text { Behavioral Development - Behavior Problems, Adaptive Behavior } \\
\text { Placement Stability - Length of Placement }\end{array}$ \\
\hline
\end{tabular}




\begin{tabular}{ll}
\hline Methods & $\begin{array}{l}\text { Multivariate effect sizes adjusted using covariates for problem behaviors } \\
\text { score, number of children in home, age of child, type of care, gender of child, } \\
\text { parent ethnicity, and child ethnicity }\end{array}$ \\
\hline Participants & $\begin{array}{l}\text { Kinship } n=88 \\
\text { Foster } n=158 \\
\text { Subjects participated in a foster care "as usual" control condition in a larger } \\
\text { study testing the effectiveness of an intervention aimed at strengthening the } \\
\text { parenting skills of foster and kinship parents in state foster homes in San } \\
\text { Diego County of California }\end{array}$ \\
\hline Interventions & See Table 6 \\
\hline Outcomes & Placement Stability - Placement Disruption \\
\hline Notes & \\
\hline
\end{tabular}

Chapman 2004

\begin{tabular}{ll}
\hline Methods & $\begin{array}{l}\text { No control for confounders } \\
\text { No demographic comparison }\end{array}$ \\
\hline Participants & $\begin{array}{l}\text { Kinship } \mathrm{n}=36 \\
\text { Foster } \mathrm{n}=82 \\
\text { Nationwide sample drawn from NSCAW of children in care for } 12 \text { months } \\
\text { and age } 6 \text { or over }\end{array}$ \\
\hline Interventions & See Table 6 \\
\hline Outcomes & Family Relations - Attachment \\
\hline Notes & \\
\hline
\end{tabular}

Chew 1998

\begin{tabular}{ll}
\hline Methods & $\begin{array}{l}\text { No control for confounders } \\
\text { No demographic comparison }\end{array}$ \\
\hline Participants & $\begin{array}{l}\text { Kinship } n=7 \\
\text { Foster } n=24 \\
\text { Drawn from children, between the ages of 23 and 48 months, in foster care } \\
\text { who have been followed, longitudinally, through a research study at an inner } \\
\text { city hospital foster care program in California }\end{array}$ \\
\hline Interventions & See Table 6 \\
\hline Outcomes & Family Relations - Attachment \\
\hline Notes & \\
\hline
\end{tabular}

Christopher 1998

\begin{tabular}{ll}
\hline Methods & $\begin{array}{l}\text { No control for confounders } \\
\text { No demographic comparison }\end{array}$ \\
\hline Participants & Kinship $n=24$ \\
& $\begin{array}{l}\text { Foster } n=42 \\
\text { Consisted of closed case files within the Permanent Placement Units of the }\end{array}$ \\
\hline
\end{tabular}


Department of Human Services in Kern County of those youth who emancipated in 1995 and 1996

\begin{tabular}{ll}
\hline Interventions & See Table 6 \\
\hline Outcomes & Educational Attainment - Graduation \\
\hline Notes & \\
\hline
\end{tabular}

Clyman 1998

\begin{tabular}{ll}
\hline Methods & $\begin{array}{l}\text { Multivariate effect sizes adjusted using covariates for caregiver education, } \\
\text { lifetime births, lifetime number foster children, income, and placement } \\
\text { duration } \\
\text { Demographic comparison using gender, age, ethnicity, parental status, } \\
\text { caregiver education and employment, duration in care, and income }\end{array}$ \\
\hline Participants & $\begin{array}{l}\text { Kinship } n=41 \\
\text { Foster } n=48 \\
\text { Local sample drawn from suburban eastern county using all families with } \\
\text { placements for three months; random sample of one child from each family }\end{array}$ \\
\hline Interventions & See Table 6 \\
\hline Outcomes & Service Utilization - Mental Health Services, Developmental Services, \\
& Physician Services \\
& Placement Stability - Length of Stay (OOH) \\
\hline Notes &
\end{tabular}

Cole 2006

\begin{tabular}{ll}
\hline Methods & $\begin{array}{l}\text { Demographic comparison using gender, race/ethnicity, age and time in } \\
\text { home }\end{array}$ \\
\hline Participants & $\begin{array}{l}\text { Kinship } \mathrm{n}=12 \\
\text { Foster } \mathrm{n}=34 \\
\text { Drawn from all kin and unrelated caregivers in the county child welfare } \\
\text { database who had infants } 10-15 \text { months of age, who had been placed with } \\
\text { the caregiver within the first } 3 \text { months of the child's life and who had been } \\
\text { with the identified caregivers continuously for at least } 6 \text { months }\end{array}$ \\
& See Table 6 \\
\hline Interventions & $\begin{array}{l}\text { Family Relations - Attachment } \\
\text { Outcomes }\end{array}$ \\
\hline Notes & \\
\hline
\end{tabular}

\section{Connell $2006 a$}

\begin{tabular}{ll}
\hline Methods & $\begin{array}{l}\text { Multivariate effect sizes adjusted using covariates for child variables and } \\
\text { episode variables }\end{array}$ \\
\hline Participants & Kinship $n=1,310$ \\
& $\begin{array}{l}\text { Foster } n=2,108 \\
\text { Local sample drawn from Rhode Island Department of Children, Youth, and } \\
\text { Families. Included all children with initial placement between 1998 and 2002. }\end{array}$ \\
\hline
\end{tabular}




\begin{tabular}{ll}
\hline Interventions & See Table 6 \\
\hline Outcomes & Permanency - Reunification, Adoption \\
\hline Notes & \\
\hline
\end{tabular}

Connell 2006b

\begin{tabular}{ll}
\hline Methods & $\begin{array}{l}\text { Multivariate effect sizes adjusted using covariates for age at entry to care, } \\
\text { gender, race and ethnicity, child risk factors, prior removals, reason for } \\
\text { removal, and service setting }\end{array}$ \\
\hline Participants & $\begin{array}{l}\text { Kinship } n=1,310 \\
\text { Foster } n=2,108 \\
\text { Drawn from all foster care placements in Rhode Island for the period from } \\
\text { January } 1,1998 \text { through December 31, 2002 }\end{array}$ \\
\hline Interventions & See Table 6 \\
\hline Outcomes & Placement Stability - Placement Disruption \\
\hline Notes & \\
\hline
\end{tabular}

Courtney 1995

\begin{tabular}{ll}
\hline Methods & $\begin{array}{l}\text { Multivariate effect sizes adjusted using covariates for age at exit from care, } \\
\text { race/ethnicity, health problems, poverty, last placement before discharge, } \\
\text { placement stability, and time in care before discharge }\end{array}$ \\
\hline Participants & $\begin{array}{l}\text { Kinship } n=2,976 \\
\text { Foster } n=3,132 \\
\text { Drawn from a population of } 6,831 \text { children, discharged to their families, from } \\
\text { a first episode in the foster care system in California between January } 1 \text { and } \\
\text { June } 30,1988, \text { and whose foster care status was monitored through June } \\
1991\end{array}$ \\
\hline Interventions & See Table 6 \\
\hline Outcomes & Placement Stability - re-entry \\
\hline Notes & \\
\hline
\end{tabular}

Courtney 1996 a

\begin{tabular}{ll}
\hline Methods & $\begin{array}{l}\text { Multivariate effect sizes adjusted using covariates for demographic and } \\
\text { placement variables }\end{array}$ \\
\hline Participants & $\begin{array}{l}\text { Kinship } n=668 \\
\text { Foster } n=1,016 \\
\text { Local sample from Children's Services Archive in California. Sample } \\
\text { determined by discharge between 1991 and 1992, 17 years of age or older } \\
\text { at exit, at least 18 months in foster care prior to exit. }\end{array}$ \\
\hline Interventions & See Table 6 \\
\hline Outcomes & Permanency - Reunification, Adoption \\
\hline Notes & \\
\hline
\end{tabular}




\begin{tabular}{ll}
\hline Methods & $\begin{array}{l}\text { Multivariate effect sizes adjusted using covariates for child variables, family } \\
\text { variables, and placement variables }\end{array}$ \\
\hline Participants & $\begin{array}{l}\text { Kinship } n=2,092 \\
\text { Foster } n=5,342 \\
\text { Local sample from California foster care system with entry into care in } 1988 . \\
\text { All children meeting criteria included in sample and assigned to comparison } \\
\text { groups based on discharge type. }\end{array}$ \\
\hline Interventions & See Table 6 \\
\hline Outcomes & Permanency - Reunification, Adoption \\
\hline Notes & \\
\hline
\end{tabular}

Courtney $1997 a$

\begin{tabular}{ll}
\hline Methods & $\begin{array}{l}\text { Multivariate effect sizes adjusted using covariates for child gender, } \\
\text { race/ethnicity, age at entry to out-of-home care, health problems, removal } \\
\text { and placement variables, AFDC eligibility, and county type }\end{array}$ \\
\hline Participants & $\begin{array}{l}\text { Kinship } n=6,588 \\
\text { Foster } n=13,431 \\
\text { Drawn from California child welfare administrative data kept at the Children's } \\
\text { Services Archive of the Child Welfare Research Center at the University of } \\
\text { California, Berkeley } \\
\text { Sample composed of all abused or neglected children placed for the first } \\
\text { time in out-of-home by California county child welfare departments during } \\
\text { 1988, who were 12 years or younger at the time of placement }\end{array}$ \\
\hline Interventions & See Table 6 \\
\hline Outcomes & $\begin{array}{l}\text { Placement Stability - re-entry } \\
\text { Permanency - Reunification }\end{array}$ \\
\hline Notes & \\
\hline
\end{tabular}

Courtney $1997 b$

\begin{tabular}{ll}
\hline Methods & $\begin{array}{l}\text { No control for confounders for kinship-foster comparisons } \\
\text { No demographic comparison }\end{array}$ \\
\hline Participants & Kinship $n=3,487$ \\
& $\begin{array}{l}\text { Foster } n=7,702 \\
\text { Drawn from data entered in the University of California Foster Care } \\
\text { Database consisting of administrative data on children who resided in } \\
\text { substitute care in California in January } 1988 \text { or who entered care any time } \\
\text { between that date and June 1994 } \\
\text { To examine placement stability, sample drawn from all children who entered } \\
\text { care during the first four months of 1988 who were initially placed in either } \\
\text { foster family homes or in kinship foster care - followed through the end of } \\
\text { 1992 (cases divided, for analysis, between open and closed cases) }\end{array}$ \\
\hline Interventions & See Table 6 \\
\hline Outcomes & Placement Stability - Number of Placements \\
\hline Notes & \\
\hline
\end{tabular}




\begin{tabular}{ll}
\hline Methods & $\begin{array}{l}\text { Multivariate effect sizes adjusted using covariates for placement variables, } \\
\text { caregiver variables, and child variables }\end{array}$ \\
\hline Participants & $\begin{array}{l}\text { Kinship } \mathrm{n}=8 \\
\text { Foster } \mathrm{n}=22 \\
\text { Drawn from African-American adolescents, ages 12 to 18, currently placed } \\
\text { in foster care from five counties in New York State }\end{array}$ \\
\hline Interventions & See Table 6 \\
\hline Outcomes & $\begin{array}{l}\text { Behavioral Development - Behavior Problems } \\
\text { Family Relations - Attachment } \\
\text { Placement Stability - Length of Placement, Number of Placements }\end{array}$ \\
\hline Notes & \\
\hline
\end{tabular}

\section{Frame 2000}

\begin{tabular}{ll}
\hline Methods & $\begin{array}{l}\text { Multivariate effect sizes adjusted using covariates for maternal criminal } \\
\text { history, child age at placement, type of placement prior to reunification, and } \\
\text { maternal substance abuse }\end{array}$ \\
\hline Participants & $\begin{array}{l}\text { Kinship } n=26 \\
\text { Foster } n=62 \\
\text { Random sample drawn for } 200 \text { infants (ages } 1 \text { day to } 12 \text { months), from } \\
\text { administrative database that is part of the California Children's Services } \\
\text { Authority (the Foster Care Information System), who entered out-of-home } \\
\text { care in a large urban county between } 1990 \text { and 1992, who subsequently } \\
\text { reunified with at least one parent, and whose record could be tracked } \\
\text { through January 1996 }\end{array}$ \\
& See Table 6 \\
\hline Interventions & Placement Stability - re-entry \\
\hline Outcomes & \\
\hline Notes &
\end{tabular}

Frame 2002

\begin{tabular}{ll}
\hline Methods & $\begin{array}{l}\text { Multivariate effect sizes adjusted using covariates for child race, gender, } \\
\text { age, removal and placement variables, and length of stay }\end{array}$ \\
\hline Participants & $\begin{array}{l}\text { Kinship } n=314 \\
\text { Foster } n=960 \\
\text { Drawn from all children, ages zero to 2-1/2 years, who were placed in foster } \\
\text { care between July 1, 1991 and June 30, 1992, in six California counties - } \\
\text { followed through December 31, 1995 }\end{array}$ \\
\hline Interventions & See Table 6 \\
\hline Outcomes & $\begin{array}{l}\text { Placement Stability - re-entry } \\
\text { Permanency - Reunification, Still in Placement }\end{array}$ \\
\hline Notes & \\
\hline
\end{tabular}

Fuller 2005 


\begin{tabular}{ll}
\hline Methods & $\begin{array}{l}\text { Multivariate effect sizes adjusted using covariates for child variables, } \\
\text { caretaker variables, placement variables, family environment variables, } \\
\text { service provision variables, and casework behavior variables }\end{array}$ \\
\hline Participants & Kinship $n=77$ \\
& $\begin{array}{l}\text { Foster } n=62 \\
\text { Non-random sample of children drawn from Illinois Child and Youth- } \\
\text { Centered Information System database for all children with an exit type of } \\
\text { "return home" during FY 98 through FY01. } \\
\text { Children were matched, } 1 \text { comparison child for each child identified as } \\
\text { having been maltreated; matching characteristics are not provided }\end{array}$ \\
\hline Interventions & See Table 6 \\
\hline Outcomes & Re-Abuse - Recurrence of Abuse \\
\hline Notes & \\
\hline
\end{tabular}

Grogan-Kaylor 2000

\begin{tabular}{ll}
\hline Methods & $\begin{array}{l}\text { Multivariate effect sizes adjusted using covariates for individual variables, } \\
\text { family variables, population level variables of the foster care caseload of the } \\
\text { counties in which children were placed, and foster care licensing variables }\end{array}$ \\
\hline Participants & $\begin{array}{l}\mathrm{N}=16,866 \\
\text { Based on a 10\% random sample of initial placements in care between } 1988 \\
\text { and 1995 } \\
\text { Local samples used from The Foster Care Information System (FCIS) in } \\
\text { California }\end{array}$ \\
\hline Interventions & See Table 6 \\
\hline Outcomes & Permanency - Reunification \\
\hline Notes & \\
\hline
\end{tabular}

Harris 2003

\begin{tabular}{ll}
\hline Methods & $\begin{array}{l}\text { No control for confounders } \\
\text { No demographic comparison }\end{array}$ \\
\hline Participants & Kinship $n=41$ \\
& $\begin{array}{l}\text { Foster } n=155 \\
\text { Random sample drawn from counties in Alabama using Court Monitor's } \\
\text { office sampling } \\
\text { Sample includes all state sampled open cases from 1997 through } 2001 \\
\text { meeting study criteria }\end{array}$ \\
\hline Interventions & See $\underline{\text { Table 6 }}$ \\
\hline Outcomes & Mental Health - Psychiatric Disorders \\
& Placement Stability - Number of Placements \\
\hline Notes & \\
\hline
\end{tabular}

Holtan 2005

Methods Multivariate effect sizes adjusted using covariates for child variables, placement variables and caregiver variables 


\begin{tabular}{ll}
\hline Participants & $\begin{array}{l}\text { Kinship } n=110 \\
\text { Foster } n=89 \\
\text { Drawn from children in state custody, aged 4-13, with a minimum stay of one } \\
\text { year in kinship or non-kinship foster care in Norway }\end{array}$ \\
\hline Interventions & See Table 6 \\
\hline Outcomes & Behavioral Development - Behavior Problems, Adaptive Behaviors \\
\hline Notes & \\
\hline
\end{tabular}

Iglehart 1994

\begin{tabular}{ll}
\hline Methods & $\begin{array}{l}\text { Demographic comparison using ethnicity, gender, removal reason, } \\
\text { placement history, and length of stay }\end{array}$ \\
\hline Participants & $\begin{array}{l}\text { Kinship } n=352 \\
\text { Foster } n=638 \\
\text { Drawn from Los Angeles County data that included only adolescents, 16 } \\
\text { years of age and older, in relative placements or in non-relative foster family } \\
\text { placements, as well as, only white, African-American and Hispanic } \\
\text { adolescents }\end{array}$ \\
\hline Interventions & See Table 6 \\
\hline Outcomes & $\begin{array}{l}\text { Behavioral Development - Behavioral Problems } \\
\text { Mental Health - Psychiatric Disorders } \\
\text { Educational Attainment - Grade Level }\end{array}$ \\
\hline Notes & \\
\hline
\end{tabular}

Iglehart 1995

\begin{tabular}{ll}
\hline Methods & $\begin{array}{l}\text { No control for confounders } \\
\text { Demographic comparison using gender and ethnicity }\end{array}$ \\
\hline Participants & Kinship $n=42$ \\
& $\begin{array}{l}\text { Foster } n=69 \\
\text { Drawn from adolescents } 16 \text { and older, under the supervision of the Los } \\
\text { Angeles County Department of Children Services (DCS), in out-of-home } \\
\text { placement, as well as adolescents, 16 and older, from a high school in Los } \\
\text { Angeles County living with one or both biological parents and not under any } \\
\text { supervision by DCS }\end{array}$ \\
& See Table 6 \\
\hline Interventions & Educational Attainment - Grade Level \\
\hline Outcomes & \\
\hline Notes & \\
\hline
\end{tabular}

Jenkins 2002

\begin{tabular}{ll}
\hline Methods & $\begin{array}{l}\text { No control for confounders } \\
\text { No demographic comparison }\end{array}$ \\
\hline Participants & Kinship $n=76$ \\
& Foster $n=105$ \\
& Drawn from children who were in the foster care of relatives or non-relatives, \\
\hline
\end{tabular}


for at least 14 weeks, in two of New York City's voluntary, contract foster care agencies in 1996

\begin{tabular}{ll}
\hline Interventions & See Table 6 \\
\hline Outcomes & Placement Stability - Length of Stay $(\mathrm{OOH})$ \\
& Family Relations - Attachment \\
& Service Utilization - Mental Health Services \\
\hline Notes & \\
\hline
\end{tabular}

\section{Jones-Karena 1998}

\begin{tabular}{ll}
\hline Methods & $\begin{array}{l}\text { No control for confounders } \\
\text { No demographic comparison }\end{array}$ \\
\hline Participants & Kinship $n=159$ (behavior problems outcome) \\
& $\begin{array}{l}\text { Foster } n=241 \text { (behavior problems outcome) } \\
\text { Kinship } n=107 \text { (adaptive behavior outcome) } \\
\text { Foster } n=164 \text { (adaptive behavior outcome) } \\
\text { Drawn from a database maintained at a children's hospital outpatient clinic } \\
\\
\end{array} \quad \begin{array}{l}\text { located in Buffalo, New York; information contained in the database taken } \\
\text { from psychological assessments of children in foster care in Erie County, as } \\
\text { all children in New York state that are waiting for adoption must have } \\
\text { psychological evaluations completed before the adoption can be finalized }\end{array}$ \\
\hline Interventions & See Table 6 \\
\hline Outcomes & Behavioral Development - Behavior Problems, Adaptive Behaviors \\
\hline Notes & \\
\hline
\end{tabular}

Jonson-Reid 2003

\begin{tabular}{ll}
\hline Methods & $\begin{array}{l}\text { Multivariate effect sizes adjusted using covariates for child demographic } \\
\text { variables, family of origin variables, child abuse and neglect report variables, } \\
\text { provision of in-home service prior to or following out-of-home placement, and } \\
\text { foster care variables }\end{array}$ \\
\hline Participants & $\begin{array}{l}\text { Kinship } n=360 \\
\text { Foster } n=823 \\
\\
\text { Local sample drawn from Missouri case files for children who entered care in } \\
\\
1993 \text { or } 1994 \text { and exited during } 4.5 \text { year study period; all cases meeting } \\
\text { study criteria were included }\end{array}$ \\
\hline Interventions & See Table 6 \\
\hline Outcomes & Re-abuse - Recurrence of Abuse \\
& Placement Stability - re-entry \\
\hline Notes & \\
\hline
\end{tabular}

Landsverk 1996

\begin{tabular}{ll}
\hline Methods & $\begin{array}{l}\text { No control for confounders for kinship-foster comparison } \\
\text { Demographic comparison using age, gender, ethnicity, parental status, and } \\
\text { removal reason }\end{array}$ \\
\hline Participants & Kinship $n=298$ \\
\hline
\end{tabular}


Foster $\mathrm{n}=371$

Drawn from cohort of children, between the ages of 0 and 16 , who entered out-of-home placement in San Diego County between May 1990 and

October 1991, and remained in placement for at least five months

\begin{tabular}{ll}
\hline Interventions & See Table 6 \\
\hline Outcomes & Behavioral Development - Behavior Problems \\
\hline Notes & \\
\hline
\end{tabular}

Leslie 200oa

\begin{tabular}{ll}
\hline Methods & $\begin{array}{l}\text { Multivariate effect sizes adjusted using covariates for age at entry into foster } \\
\text { care placement, race/ethnicity, gender, maltreatment history, placement } \\
\text { pattern, and presence of clinically significant behavior problems }\end{array}$ \\
\hline Participants & $\begin{array}{l}\text { Kinship } n=53 \\
\text { Foster } n=243 \\
\text { Local sample of children 0-16 in San Diego County from 1990-1991 drawn } \\
\text { from larger longitudinal study }\end{array}$ \\
\hline Interventions & See Table 6 \\
\hline Outcomes & Service Utilization - Mental Health Services \\
\hline Notes &
\end{tabular}

Mcintosh 2002

\begin{tabular}{ll}
\hline Methods & Demographic comparison using gender, ethnicity, and reason for placement \\
\hline Participants & Kinship $\mathrm{n}=39$ \\
& $\begin{array}{l}\text { Foster } \mathrm{n}=54 \\
\text { Purposive samples drawn for outcomes of Family Maintenance (reunified) } \\
\text { cases and Permanent Placement (non-reunified) cases in Los Angeles } \\
\text { County }\end{array}$ \\
\hline Interventions & See Table 6 \\
\hline Outcomes & Permanency - Reunification \\
\hline Notes & \\
\hline
\end{tabular}

McMillen 2004

\begin{tabular}{ll}
\hline Methods & $\begin{array}{l}\text { Multivariate effect sizes adjusted using covariates for predisposing variables, } \\
\text { enabling variables, and need variables }\end{array}$ \\
\hline Participants & Kinship $n=75$ \\
& $\begin{array}{l}\text { Foster } n=115 \\
\text { Sample drawn from Missouri foster care system between } 2001 \text { and } 2003 \\
\\
\text { Purposive sample of all youth meeting criteria including turning seventeen, } \\
\text { living in specified region, and not having continual runaway status. }\end{array}$ \\
\hline Interventions & See Table 6 \\
\hline Outcomes & Service Utilization - Mental Health Services \\
\hline Notes &
\end{tabular}




\begin{tabular}{ll}
\hline Methods & $\begin{array}{l}\text { Multivariate effect sizes adjusted using covariates for demographic } \\
\text { variables, maltreatment history variables, and living situation difference } \\
\text { variables }\end{array}$ \\
\hline Participants & $\begin{array}{l}\text { Kinship } \mathrm{n}=75 \\
\text { Foster } \mathrm{n}=115 \\
\text { Local sample from Missouri Division of Family Services of youth turning 17 } \\
\text { between 2001-2003. }\end{array}$ \\
\hline Interventions & See Table 6 \\
\hline Outcomes & Mental Health - Psychiatric Disorders \\
\hline Notes & \\
\hline
\end{tabular}

Metzger 1997

\begin{tabular}{ll}
\hline Methods & $\begin{array}{l}\text { Multivariate effect sizes adjusted using covariates for age of child, gender of } \\
\text { child, birth mother visits, and placement variables } \\
\text { Demographic comparison using gender, ethnicity, and reason for placement }\end{array}$ \\
\hline Participants & $\begin{array}{l}\text { Kinship } \mathrm{n}=52 \\
\text { Foster } \mathrm{n}=55 \\
\text { Local sample drawn from private, non-profit agency in Manhattan includes } \\
\text { all children over age of seven in placement during three month study period. }\end{array}$ \\
\hline Interventions & See Table 6 \\
\hline Outcomes & Mental Health - Well-Being \\
& $\begin{array}{l}\text { Placement Stability - Number of Placements, Length of Placement } \\
\text { Educational Attainment - Repeated a Grade } \\
\text { Behavioral Development - Behavior Problems } \\
\text { Service Utilization - Mental Health Services }\end{array}$ \\
\hline Notes &
\end{tabular}

Mosek 2001

\begin{tabular}{ll}
\hline Methods & $\begin{array}{l}\text { Demographic comparison using child variables, family variables, foster } \\
\text { parent variables, and family relation variables }\end{array}$ \\
\hline Participants & $\begin{array}{l}\text { Kinship } \mathrm{n}=20 \\
\text { Foster } \mathrm{n}=18 \\
\text { Purposive sample of all girls age 12-18 in foster care in northern Israel } \\
\text { during study period (1994-1996) who had been in care at least 4 years. }\end{array}$ \\
\hline Interventions & See Table 6 \\
\hline Outcomes & Mental Health - Well-Being \\
& Family Relations - Attachment \\
\hline Notes & \\
\hline
\end{tabular}

\section{Rudenberg 1991}

Methods

Multivariate effect sizes adjusted using covariates for age and gender

Demographic comparisons using ethnicity, age, and gender 


\begin{tabular}{ll}
\hline Participants & Kinship $n=28$ \\
& Foster $n=28$ \\
& Drawn from formerly abused children, ages 8 through 17, who were living \\
& with at least one biological grandparent or living with their foster families \\
& Grandparent caregivers included members of a group in the San Diego area \\
& called Grandparents Offering Love and Direction (GOLD), members \\
participating in a therapeutic support group for grandparents raising \\
grandchildren, and grandparents who sought arbitration through Family \\
Court Services and were awarded custody of their grandchildren by the \\
Superior Court of San Diego county \\
Foster children were selected from the Family Care Resource Center, a \\
foster care agency in San Diego county, and a research study conducted by \\
the San Diego Foster Children's Health Project, a joint demonstration project \\
by the Center for Child Protection of Children's Hospital and Health Center in \\
San Diego and the Child Resource Division of the San Diego County \\
Department of Social Services
\end{tabular}

\section{Sallnas 2004}

\begin{tabular}{ll}
\hline Methods & $\begin{array}{l}\text { No control for confounders } \\
\text { No demographic comparison }\end{array}$ \\
\hline Participants & $\begin{array}{l}\text { Kinship } n=144 \\
\text { Foster } n=323 \\
\text { Drawn from a cohort of youths, aged 13-16 years, who were placed in out- } \\
\text { of-home care in 1991 according to a national database maintained by the } \\
\text { Swedish National Board of Health and Welfare; every second youth } \\
\text { experiencing his/her first placement during 1991 in foster family care } \\
\text { randomly selected, but included all youths whose first placement was in } \\
\text { residential care }\end{array}$ \\
\hline Interventions & See Table 6 \\
\hline Outcomes & Placement Stability - Placement Disruption \\
\hline Notes & \\
\hline
\end{tabular}

Scannapieco 1997

\begin{tabular}{ll}
\hline Methods & $\begin{array}{l}\text { No control for confounders } \\
\text { Demographic comparison using setting, placement characteristics, and child } \\
\text { variables }\end{array}$ \\
\hline Participants & $\begin{array}{l}\text { Kinship } n=47 \\
\text { Foster } n=59 \\
\text { Local sample of Maryland foster homes } \\
\text { Study includes all kin homes open in 1993 and a random sample of } \\
\text { traditional foster homes }\end{array}$ \\
\hline Interventions & See Table 6 \\
\hline Outcomes & Service Utilization - Mental Health Services, Physician Services \\
\hline
\end{tabular}


Notes

Shin 2003

\begin{tabular}{ll}
\hline Methods & $\begin{array}{l}\text { Multivariate effect sizes adjusted using covariates for individual variables, } \\
\text { mental health variables, placement variables, school variables, mental } \\
\text { health service use variables, and victimization variables }\end{array}$ \\
\hline Participants & $\begin{array}{l}\text { Kinship } n=58 \\
\text { Foster } n=36 \\
\text { Random sample of older foster youth selected from the Illinois Department } \\
\text { of Children and Family Services Integrated Database maintained by the } \\
\text { Chapin Hall Center for Children at the University of Chicago; population from } \\
\text { which the sample was chosen consisted of youth in substitute care in the } \\
\text { state of Illinois between the ages of } 16.5 \text { and } 17.5 \text { years as of December } 1, \\
\text { 1998; after collecting data from the first sample, the sample size was } \\
\text { augmented to increase generalizability of the study findings, thus, another } \\
\text { random sample of youth, between } 16.5 \text { and } 17.5 \text { years old, in out-of-home } \\
\text { care was selected as of February 1, 2000 }\end{array}$ \\
\hline Interventions & See Table 6 \\
\hline Outcomes & Educational Attainment - Grade Level \\
\hline Notes & \\
\hline
\end{tabular}

Sivright 2004

\begin{tabular}{ll}
\hline Methods & $\begin{array}{l}\text { No control for confounders } \\
\text { Demographic comparison using age at placement, gender, ethnicity, and } \\
\text { reason for placement }\end{array}$ \\
\hline Participants & $\begin{array}{l}\text { Kinship } n=51 \\
\text { Foster } n=67 \\
\text { Local sample randomly drawn from New York foster care agency and } \\
\text { including only children who experienced initial placement between 1995 and } \\
\end{array}$ \\
& Se00 and were age 12 or under. \\
\hline Interventions & Placement Stability - Length of Stay $(\mathrm{OOH})$ \\
\hline Outcomes & Service Utilization - Mental Health Services \\
& Permanency - Still in Placement \\
\hline Notes &
\end{tabular}

Smith 2002

\begin{tabular}{ll}
\hline Methods & Demographic comparison using age, gender, and race/ethnicity \\
\hline Participants & Kinship $n=39$ \\
& $\begin{array}{l}\text { Foster } n=36 \\
\text { Sample drawn from all identified kinship placements in one New York county } \\
\text { between October } 1993 \text { and April 1994; only infants were used for this study. }\end{array}$ \\
\hline Interventions & See Table 6 \\
\hline
\end{tabular}




\begin{tabular}{ll}
\hline Outcomes & Permanency - Adoption, Reunification, Still in Placement \\
\hline Notes & \\
\hline
\end{tabular}

Smith 2003

\begin{tabular}{ll}
\hline Methods & Multivariate effect sizes adjusted using covariates for child, family, and case \\
& variables \\
\hline Participants & Kinship $\mathrm{n}=379$ \\
& $\begin{array}{l}\text { Foster } \mathrm{n}=878 \\
\text { National sample drawn from the Adoption and Foster Care Analysis and } \\
\text { Reporting System (AFCARS) based on termination of parental rights in } \\
\text { October 1997 }\end{array}$ \\
\hline Interventions & See Table 6 \\
\hline Outcomes & Permanency - Still in Placement \\
\hline Notes & \\
\hline
\end{tabular}

Sripathy 2004

\begin{tabular}{ll}
\hline Methods & Demographic comparison using reason for placement \\
\hline Participants & $\begin{array}{l}\text { Kinship } n=31 \\
\text { Foster } n=31 \\
\text { Recruited from foster care agency located in New York City; youth required } \\
\text { to have been living with their foster families for at least six months }\end{array}$ \\
\hline Interventions & See Table 6 \\
\hline Outcomes & $\begin{array}{l}\text { Educational Attainment - Repeated a Grade } \\
\text { Service Utilization - Mental Health Services } \\
\text { Behavioral Development - Behavior Problems, Adaptive Behaviors }\end{array}$ \\
\hline Notes & \\
\hline
\end{tabular}

Strijker 2003

\begin{tabular}{ll}
\hline Methods & $\begin{array}{l}\text { No control for confounders for kinship-foster comparison } \\
\text { No demographic comparison }\end{array}$ \\
\hline Participants & Kinship $\mathrm{n}=68$ \\
& $\begin{array}{l}\text { Foster } \mathrm{n}=52 \\
\text { Convenience sample determined by caseworkers estimation of long term } \\
\text { care } \\
\text { Local sample in Netherlands }\end{array}$ \\
\hline Interventions & See Table 6 \\
\hline Outcomes & $\begin{array}{l}\text { Family Relations - Attachment } \\
\text { Behavioral Development - Behavior Problems }\end{array}$ \\
\hline Notes & \\
\hline
\end{tabular}

Surbeck 2000 


\begin{tabular}{ll}
\hline Methods & $\begin{array}{l}\text { Multivariate effect sizes adjusted using covariates for child, parent, and } \\
\text { caregiver characteristics } \\
\text { Demographic comparison using child variables, biological mother variables, } \\
\text { caregiver variables, material resource variables, attachment variables, } \\
\text { frequency of visitation variables, and service variables }\end{array}$ \\
\hline Participants & $\begin{array}{l}\text { Kinship } n=98 \\
\text { Foster } n=102 \\
\text { Local sample drawn from one agency's case records in Pennsylvania } \\
\text { Purposive sample of all cases meeting criteria during study period }\end{array}$ \\
\hline Interventions & See Table 6 \\
\hline Outcomes & Behavioral Development - Behavior Problems, Adaptive Behavior \\
& $\begin{array}{l}\text { Family Relations - Attachment } \\
\text { Placement Stability - Length of Placement }\end{array}$ \\
\hline Notes &
\end{tabular}

Tarren-Sweeney 2006

\begin{tabular}{ll}
\hline Methods & No control for confounders \\
& No demographic comparison \\
\hline Participants & Kinship $n=50$ \\
& Foster $n=297$ \\
& Drawn from all 4 to 9 year old children residing in foster or kinship care in \\
& NSW, Australia, under the guardianship of the Minister for Department of \\
& Community Services (DOCS), and for whom casework responsibility rested \\
& with DOCS
\end{tabular}

Testa 1999

\begin{tabular}{ll}
\hline Methods & $\begin{array}{l}\text { No control for confounders } \\
\text { No demographic comparison }\end{array}$ \\
\hline Participants & $\begin{array}{l}\text { Kinship } n=2,159 \\
\text { Foster } n=4,003 \\
\text { Local sample drawn from professional foster care program in Illinois; random } \\
\text { samples of comparison groups from similar agencies. }\end{array}$ \\
\hline Interventions & See Table 6 \\
\hline Outcomes & Permanency - Reunification, Adoption, Guardianship \\
\hline Notes & \\
\hline
\end{tabular}

Testa 2001

Methods

Multivariate effect sizes adjusted using covariates for age, duration of placement, kinship status, gender, placement variables, and degree of relatedness 


\begin{tabular}{ll}
\hline Participants & Kinship $n=955$ \\
& Foster $n=955$ \\
& Data drawn from two sources: (1) the IDCFS Integrated Database designed \\
& for the Department of the Chapin Hall Center for Children, and (2) the 1994 \\
& Relative Caregiver Social Assessment (RCSA) survey \\
& Administrative case records extracted from the Integrated Database of \\
& kinship and non-related foster placements that began in Cook County, \\
& lllinois between July 1, 1991 and June 30, 1995 - placements tracked \\
& longitudinally with administrative data until case resolution, placement \\
& disruption or June 30, 1999 \\
& Dataset created by linking records from the Integrated Database to RCSA \\
& respondents - a comparable sample of children in non-related foster care \\
& was matched by the child's age and duration of placement \\
\hline Interventions & See Table 6 \\
\hline Outcomes & Placement Stability - Placement Disruption \\
& Permanency - Adoption, Guardianship \\
\hline Notes & \\
\hline
\end{tabular}

Timmer 2004

\begin{tabular}{ll}
\hline Methods & $\begin{array}{l}\text { No control for confounders for kinship-foster comparison } \\
\text { Demographic comparison using child gender, age, ethnicity, abuse history, } \\
\text { and length in placement, and caregiver ethnicity, educational attainment, } \\
\text { and marital status }\end{array}$ \\
\hline Participants & $\begin{array}{l}\text { Kinship } n=92 \\
\text { Foster } \mathrm{n}=141 \\
\text { Drawn from kin and non-kin foster parents and children who had been } \\
\text { referred for Parent-Child Interaction Therapy (PCIT) services at a clinic } \\
\text { primarily serving children in the child welfare system }\end{array}$ \\
\hline Interventions & See Table 6 \\
\hline Outcomes & Behavioral Development - Behavior Problems \\
\hline Notes & \\
\hline
\end{tabular}

Tompkins 2003

\begin{tabular}{ll}
\hline Methods & $\begin{array}{l}\text { No control for confounders for kinship-foster comparisons } \\
\text { Demographic comparisons using caregiver age, gender, ethnicity, } \\
\text { employment status, marital status, and child age, gender, and ethnicity }\end{array}$ \\
\hline Participants & $\begin{array}{l}\text { Kinship } n=122,058 \\
\text { Foster } n=193,681 \\
\text { Drawn randomly from the National Study of Protective, Preventive and } \\
\\
\text { Reunification Services Delivered to Children and their Families receiving } \\
\text { child welfare services between March 1, 1993 and March 1, 1994 }\end{array}$ \\
\hline Interventions & See Table 6 \\
\hline Outcomes & Mental Health - Well-Being \\
& Placement Stability - Length of Stay (OOH) \\
& Service Utilization - Mental Health Services, Physician Services
\end{tabular}




\section{Notes}

Vogel 1999

\begin{tabular}{ll}
\hline Methods & $\begin{array}{l}\text { Multivariate effect sizes adjusted using covariates for race, age, gender, and } \\
\text { receipt of pre-placement services }\end{array}$ \\
\hline Participants & $\begin{array}{l}\text { Kinship } n=43 \\
\text { Foster } n=616 \\
\text { Drawn from those children entering substitute, city-funded placements, for } \\
\text { the first time, during the } 1994 \text { calendar year, and followed through February } \\
1996\end{array}$ \\
\hline Interventions & See Table 6 \\
\hline Outcomes & Placement Stability - Length of Stay $(\mathrm{OOH})$ \\
\hline Notes &
\end{tabular}

Wells 1999

\begin{tabular}{|c|c|}
\hline Methods & $\begin{array}{l}\text { Multivariate effect sizes adjusted using covariates for child age at entry, } \\
\text { gender, ethnicity, health status at entry, and removal and placement } \\
\text { variables }\end{array}$ \\
\hline Participants & $\begin{array}{l}\text { Kinship } n=1155 \\
\text { Foster } n=1157 \\
\text { Local sample drawn from county records in Ohio for children entering care } \\
1992-1993 \\
\text { Includes all children meeting study criteria during specified time period }\end{array}$ \\
\hline Interventions & See Table 6 \\
\hline Outcomes & $\begin{array}{l}\text { Placement Stability - re-entry } \\
\text { Permanency - Reunification }\end{array}$ \\
\hline Notes & \\
\hline
\end{tabular}

Wilson 1999

\begin{tabular}{ll}
\hline Methods & $\begin{array}{l}\text { No control for confounders } \\
\text { No demographic comparison }\end{array}$ \\
\hline Participants & Kinship $n=100$ \\
& $\begin{array}{l}\text { Foster } n=100 \\
\text { Sample drawn from children in out-of-home care in Illinois from 1993-1996 } \\
\\
\text { using both random sampling and stratified sampling }\end{array}$ \\
\hline Interventions & See Table 6 \\
\hline Outcomes & Mental Health - Well-Being \\
\hline Notes & \\
\hline
\end{tabular}

Zima 2000 
ethnicity, foster parent education, placement history variables. and school

history variables

\begin{tabular}{ll}
\hline Participants & Kinship $n=171$ \\
& $\begin{array}{l}\text { Foster } n=44 \\
\text { Drawn from the Los Angeles County Department of Children and Family } \\
\text { Services (DCFS) Management Information System (MIS) composed of } \\
\text { children, aged } 6 \text { through } 12 \text { years, living in out-of-home placement } \\
\text { Children selected from three of the eight county service areas, every two } \\
\text { months, between July } 1996 \text { and March 1998 }\end{array}$ \\
& See Table 6 \\
\hline Interventions & $\begin{array}{l}\text { Behavioral Development - Behavior Problems, Adaptive Behaviors } \\
\text { Educational Attainment - Repeated a Grade }\end{array}$ \\
\hline Outcomes & \\
\hline Notes & \\
\hline
\end{tabular}

Zimmerman 1998

\begin{tabular}{ll}
\hline Methods & $\begin{array}{l}\text { Multivariate effect sizes adjusted using covariates for foster care system } \\
\text { variables, child's birth family variables, child variables, placement variables, } \\
\text { and birth parent case participation variables }\end{array}$ \\
\hline Participants & $\begin{array}{l}\text { Kinship } \mathrm{n}=126 \\
\text { Foster } \mathrm{n}=197 \\
\text { Random local sample drawn from New York City foster care records }\end{array}$ \\
\hline Interventions & See Table 6 \\
\hline Outcomes & $\begin{array}{l}\text { Placement Stability - Number of Placements } \\
\text { Permanency - Reunification }\end{array}$ \\
\hline Notes & \\
\hline
\end{tabular}

Zuravin 1993

\begin{tabular}{|c|c|}
\hline Methods & $\begin{array}{l}\text { Multivariate effect sizes adjusted using covariates for application and } \\
\text { relicensing variables }\end{array}$ \\
\hline Participants & $\begin{array}{l}\text { Kinship } n=135 \\
\text { Foster } n=161 \\
\text { Non-random sample drawn from Baltimore City Department of Social } \\
\text { Services based on foster homes confirmed for maltreatment and homes that } \\
\text { were not reported for maltreatment between January } 1,1984 \text { through } \\
\text { December } 31,1988\end{array}$ \\
\hline Interventions & See Table 6 \\
\hline Outcomes & Re-abuse - Institutional Abuse \\
\hline Notes & \\
\hline
\end{tabular}

\subsection{CHARACTERISTICS OF EXCLUDED STUDIES}




Reason for exclusion $\quad$ Out of print and unavailable

Ainsworth 1998

Reason for exclusion The article/report describes a study in which there was no intervention

Ajdukovic 2004

Reason for exclusion The intervention did not include a kinship care group

Ajdukovic 2005

Reason for exclusion The intervention did not include a kinship care group

Almgren 2001

Reason for exclusion The intervention did not include a kinship care group

Altshuler 1998

Reason for exclusion The article/report describes a study in which there was no intervention

Altshuler 1999

Reason for exclusion The kinship care group was not compared with a foster care group

Anaut 1999

Reason for exclusion The intervention did not include a kinship care group

Anderson 1995

Reason for exclusion The article/report describes a study in which there was no intervention

Aquilino 1991

Reason for exclusion The study reports on an intervention other than kinship care

Armsden 2000

Reason for exclusion The intervention did not include a kinship care group

Backovic 2006

Reason for exclusion The intervention did not include a kinship care group 
Barber 2003

Reason for exclusion The intervention did not include a kinship care group

Barth 1995

Reason for exclusion The article/report describes a study in which there was no intervention

Bass 2004

Reason for exclusion The article/report describes a study in which there was no intervention

Beatty 1995

Reason for exclusion The intervention did not include a kinship care group

Benedict 1990

Reason for exclusion The foster care group was not disaggregated from other out-of-home placement types

Benedict 1994

Reason for exclusion The intervention did not include a kinship care group

Benedict 19966

Reason for exclusion The cases were drawn from a sample of adults over the age of 18

Berman 2004

Reason for exclusion The article/report describes a study in which there was no intervention

Berrick 1995

Reason for exclusion The foster care group was not disaggregated from other out-of-home placement types

Billing 2002

Reason for exclusion The kinship care group was not compared with a foster care group

Blumberg 1996

Reason for exclusion The type of placement is the outcome not the intervention

Broad 2001 
Broad 2004

Reason for exclusion Research design was descriptive, survey, or qualitative

Browne 2005

Reason for exclusion The intervention did not include a kinship care group

Browning 1994

Reason for exclusion The article/report describes a study in which there was no intervention

Cantos 1996

Reason for exclusion The kinship group was not disaggregated from the foster care group

Cariglia 1999

Reason for exclusion The research design was descriptive, survey, or qualitative

Carlson 2002

Reason for exclusion The cases were drawn from a sample of adults over the age of 18

Carpenter 2001

Reason for exclusion The cases were drawn from a sample of adults over the age of 18

Carpenter 2003

Reason for exclusion The article/report was unavailable

Carpenter 2004a

Reason for exclusion The article/report was unavailable

Carpenter $2004 \mathrm{~b}$

Reason for exclusion The cases were drawn from a sample of adults over the age of 18

Chen 2000

\begin{tabular}{ll}
\hline Reason for exclusion $\quad$ The research design was descriptive, survey, or qualitative \\
\hline
\end{tabular} 
Reason for exclusion The research design was descriptive, survey, or qualitative

Clawar 1984

Reason for exclusion The article/report describes a study in which there was no intervention

Clyman 2002

Reason for exclusion The article/report describes a study in which there was no intervention

CNNP 1996

Reason for exclusion The article/report describes a study in which there was no intervention

Cole 2001

Reason for exclusion The study reported on caregiver outcomes and physical health is not a child well-being outcome

Cole 2005a

Reason for exclusion The study reported on caregiver outcomes only

Cole $2005 b$

Reason for exclusion The intervention did not include a kinship care group

Colton 1994

Reason for exclusion The intervention did not include a kinship care group

Colton 1995

Reason for exclusion The intervention did not include a kinship care group

Courtney 1992

Reason for exclusion The article/report was unavailable

Courtney 1994

Reason for exclusion The foster care group was not disaggregated from other out-of-home placement types

Courtney 1996 


Reason for exclusion The article/report describes a study in which there was no intervention

Courtney 2001

Reason for exclusion The intervention did not include a kinship care group

Cranley 2003

Reason for exclusion The research design was descriptive, survey, or qualitative

Crawford 2006

Reason for exclusion The article/report describes a study in which there was no intervention

Cuddeback 2002

Reason for exclusion The study reported on caregiver outcomes only

CWLA 1995

Reason for exclusion The article/report was unavailable

Davidson-Arad 2003

Reason for exclusion The intervention did not include a kinship care group

Davis 1993

Reason for exclusion The article/report was unavailable

Davis 1996

Reason for exclusion The article/report was unavailable

De Cadiz 2006

Reason for exclusion The intervention was only informal kinship care

Delfabbro 2002

Reason for exclusion The intervention did not include a kinship care group

Delfabbro 2003

Reason for exclusion The intervention did not include a kinship care group 
Du 2002

Reason for exclusion The intervention did not include a kinship care group

Dubowitz 1990

Reason for exclusion $\quad$ The kinship care group was not compared with a foster care group

Dubowitz 1992

Reason for exclusion The kinship care group was not compared with a foster care group

Dubowitz $1993 a$

Reason for exclusion The kinship care group was not compared with a foster care group

Dubowitz 1993 b

Reason for exclusion $\quad$ The kinship care group was not compared with a foster care group

Dubowitz 1994b

Reason for exclusion The kinship care group was not compared with a foster care group

Dubowitz 1994c

Reason for exclusion The article/report describes a study in which there was no intervention

Duhrssen 1958

Reason for exclusion The intervention did not include a kinship care group

Dworsky 2005

Reason for exclusion The intervention did not include a kinship care group

Ehrle 2002

Reason for exclusion The study reported on caregiver outcomes only

Ehrle, Gee 2002

Reason for exclusion The kinship care group was not compared with a foster care group

English 1994

Reason for exclusion The intervention did not include a kinship care group 
Falcon 2000

Reason for exclusion The research design was descriptive, survey, or qualitative

Farmer 1991

Reason for exclusion Comparison of children in kinship care with children returned to parent

Farmer 2001

Reason for exclusion The intervention did not include a kinship care group

Feigelman 1995

Reason for exclusion The research design was descriptive, survey, or qualitative

Festinger 1996

Reason for exclusion The intervention did not include a kinship care group

Flint 1973

Reason for exclusion The intervention did not include a kinship care group

Folman 1995

Reason for exclusion The intervention did not include a kinship care group

Fong 2006

Reason for exclusion The kinship group was not disaggregated from the foster care group

Franck 2002

Reason for exclusion The article/report was unavailable

Freedman 1994

Reason for exclusion The intervention did not include a kinship care group

Garland 2003

Reason for exclusion The intervention did not include a kinship care group

Gaudin 1993

Reason for exclusion The study did not report on child outcomes 
Gebel 1996

Reason for exclusion The study reported on caregiver outcomes only

Geen 2003

Reason for exclusion The research design was descriptive, survey, or qualitative

Gennaro 1998

Reason for exclusion The research design was descriptive, survey, or qualitative

Gibbison 2005

Reason for exclusion The intervention did not include a kinship care group

Gil 1982

Reason for exclusion The intervention did not include a kinship care group

Goerge 1995

Reason for exclusion The research design was descriptive, survey, or qualitative

Gottesman 2001

Reason for exclusion The article/report describes a study in which there was no intervention

Graf 1987

Reason for exclusion The study reports on an intervention other than kinship care

Grogan-Kaylor 2001

Reason for exclusion The kinship care group was not compared with a foster care group

Groppenbacher 2002

Reason for exclusion The article/report describes a study in which there was no intervention

Haist 2005

Reason for exclusion The kinship care group was not compared with a foster care group

Hansen 2004

Reason for exclusion The intervention did not include a kinship care group 
Harden 2002

Reason for exclusion The intervention did not include a kinship care group

Harden 2004

Reason for exclusion The study did not report on child outcomes

Harman 2000

Reason for exclusion The intervention did not include a kinship care group

Hessle 1989

Reason for exclusion The intervention did not include a kinship care group

Hjern 2004

Reason for exclusion The intervention did not include a kinship care group

Holloway 1997

Reason for exclusion The intervention did not include a kinship care group

Hornby 1995

Reason for exclusion The article/report describes a study in which there was no intervention

Hornick 1989

Reason for exclusion The intervention did not include a kinship care group

Houston 1998

Reason for exclusion The study did not report on child outcomes

Hughes 1969

Reason for exclusion The research design was descriptive, survey, or qualitative

Hulsey 1989

Reason for exclusion The intervention did not include a kinship care group

Iafrate 2001

Reason for exclusion The intervention did not include a kinship care group 
Reason for exclusion The article/report describes a study in which there was no intervention

Jackson 1994

Reason for exclusion The article/report describes a study in which there was no intervention

Jaffe 2004

Reason for exclusion The intervention did not include a kinship care group

James $2004 a$

Reason for exclusion The kinship care group was not compared with a foster care group

James $2004 b$

Reason for exclusion The type of placement is the outcome not the intervention

Jantz 2002

Reason for exclusion The article/report describes a study in which there was no intervention

Jee 2005

Reason for exclusion The intervention did not include a kinship care group

Jee 2006

Reason for exclusion The intervention did not include a kinship care group

Johnson 1995

Reason for exclusion The intervention did not include a kinship care group

Jones 1998

Reason for exclusion The intervention did not include a kinship care group

Kamaiko 2003

Reason for exclusion Developmental delay is not a child well-being outcome

Kappenberg 2006 
Keller 2001

Reason for exclusion The intervention was permanent foster care placement

Kortenkamp 2002

Reason for exclusion The intervention did not include a kinship care group

Kosenen 1993

Reason for exclusion Descriptive study of foster care sample (one quarter lived in kinship care)

Kufeldt 1995

\begin{tabular}{ll} 
Reason for exclusion The intervention did not include a kinship care group \\
\hline
\end{tabular}

Laan 2001

Reason for exclusion The intervention did not include a kinship care group

Le Blanc 1991

Reason for exclusion The intervention did not include a kinship care group

Leslie $2000 \mathrm{~b}$

Reason for exclusion The kinship care group was not compared with a foster care group

Leslie 2002

Reason for exclusion Developmental delay is not a child well-being outcome

Leslie 2005

Reason for exclusion The kinship group was not disaggregated from the foster care group

Lewandowski 2002

Reason for exclusion The intervention did not include a kinship care group

Lewis 1987

Reason for exclusion The research design was descriptive, survey, or qualitative

Link 1996 
Litrownik 2003

Reason for exclusion The intervention was permanent foster care placement

Lux 2001

Reason for exclusion The intervention did not include a kinship care group

Lyman 1996

Reason for exclusion The intervention did not include a kinship care group

Macintyre 1970

Reason for exclusion The article/report describes a study in which there was no intervention

Mackintosh 2006

Reason for exclusion The kinship care group was not compared with a foster care group

Maclean 2003

Reason for exclusion The kinship group was not disaggregated from the foster care group

Maluccio 1999

Reason for exclusion The article/report describes a study in which there was no intervention

Marinkovic 2004

Reason for exclusion The intervention did not include a kinship care group

Mascorro 2003

Reason for exclusion The foster care group was not disaggregated from other out-of-home placement types

Mason 2003

Reason for exclusion The intervention did not include a kinship care group

McLean 1996

Reason for exclusion The research design was descriptive, survey, or qualitative 
Reason for exclusion The intervention did not include a kinship care group

Mech 1994

Reason for exclusion The intervention did not include a kinship care group

Minnis 2006

Reason for exclusion The kinship care group was not compared with a foster care group

Minty 2000

Reason for exclusion The article/report describes a study in which there was no intervention

Mitchell 2002

Reason for exclusion Physical health is not a child well-being outcome

Monheit 1997

Reason for exclusion The intervention did not include a kinship care group

Moore 2001

Reason for exclusion The intervention did not include a kinship care group

Mosek 1993

Reason for exclusion The intervention did not include a kinship care group

Moutassem 1999

Reason for exclusion The intervention did not include a kinship care group

Needell 1996

Reason for exclusion The foster care group was not disaggregated from other out-of-home placement types

Oyemade 1974

Reason for exclusion The kinship care group was not compared with a foster care group

Payne 2000 


Reason for exclusion The article/report describes a study in which there was no intervention

Pears 2005

Reason for exclusion The intervention did not include a kinship care group

Pecora 1998

Reason for exclusion The intervention did not include a kinship care group

Pecora 2006

Reason for exclusion The intervention did not include a kinship care group

Perez 1998

Reason for exclusion The kinship care group was not compared with a foster care group

Prosser 1997

Reason for exclusion The formal kinship care group was not disaggregated from the informal kinship placement

Ritchie 2005

Reason for exclusion The article/report describes a study in which there was no intervention

Ritter 2005

Reason for exclusion The article/report was unavailable

Rock 1988

Reason for exclusion The intervention did not include a kinship care group

Romney 2006

Reason for exclusion The type of placement is the outcome not the intervention

Roy 2000

Reason for exclusion The intervention did not include a kinship care group

Roy 2006

Reason for exclusion The intervention did not include a kinship care group 
Rubin 2004

Reason for exclusion The intervention did not include a kinship care group

Ryan 2005

Reason for exclusion The study reports on an intervention other than kinship care

Sawyer 1994

Reason for exclusion The kinship care group was not compared with a foster care group

Schwartz 2005

Reason for exclusion The research design was descriptive, survey, or qualitative

Shin 2004

Reason for exclusion The intervention did not include a kinship care group

Shlonsky 2002

Reason for exclusion The kinship care group was not compared with a foster care group

Shore 2002

Reason for exclusion The intervention was permanent foster care placement

Simard 1993

Reason for exclusion The intervention did not include a kinship care group

Smith 1986

Reason for exclusion The intervention did not include a kinship care group

Smithgall 2004

Reason for exclusion The research design was descriptive, survey, or qualitative

Sousa 2005

Reason for exclusion The article/report was unavailable

Starr 1999

Reason for exclusion

The kinship care group was not compared with a foster care group 
Stiffman 2002

Reason for exclusion The study reports on an intervention other than kinship care

Strijker 2005

Reason for exclusion The formal kinship care group was not disaggregated from the informal kinship care group

Sun 2003

Reason for exclusion The kinship care group was not disaggregated from the foster care group

Sykes 2002

Reason for exclusion The study reported on caregiver outcomes only

Taussig 2001

Reason for exclusion The study reports on an intervention other than kinship care

Tepper 1991

Reason for exclusion The article/report was unavailable

Testa 1996

Reason for exclusion The research design was descriptive, survey, or qualitative

Testa 1997

Reason for exclusion The article/report was unavailable

Testa 2002

Reason for exclusion The kinship care group was not compared with a foster care group

Thoburn 1989

Reason for exclusion The intervention did not include a kinship care group

Thornton 1991

Reason for exclusion The research design was descriptive, survey, or qualitative

Troutman 2000 


Reason for exclusion The article/report describes a study in which there was no intervention

Turner 2003

Reason for exclusion The study reports on an intervention other than kinship care

Unrau 2005

Reason for exclusion The intervention did not include a kinship care group

Unrau, Wel 2005

Reason for exclusion The study reported on birth parent outcomes only

USGAO 1999

Reason for exclusion The foster care group was not disaggregated from other out-of-home placement types

Valicenti-Mcd 2004

Reason for exclusion The article/report was unavailable

VDSS 1994

Reason for exclusion The research design was descriptive, survey, or qualitative

Vinnerljung 2005

Reason for exclusion The intervention did not include a kinship care group

Wade 2000

Reason for exclusion The intervention did not include a kinship care group

Wade 2001

Reason for exclusion The intervention did not include a kinship care group

Walsh 1981

Reason for exclusion The intervention did not include a kinship care group

Webster 2000

Reason for exclusion The foster care group was not disaggregated from other out-of-home placement types 
Wilson, Chi 1996

Reason for exclusion

The article/report describes a study in which there was no intervention

Wulczyn 1992

Reason for exclusion

The research design was descriptive, survey, or qualitative

Wulczyn 2004

Reason for exclusion The intervention did not include a kinship care group

Zuravin 1998

Reason for exclusion

The cases were drawn from a sample of adults over the age of 18

\subsection{CHARACTERISTICS OF STUDIES AWAITING CLASSIFICATION}

Berridge 1987

Methods

Participants

Interventions

Outcomes

Notes

Hunt 1999

Methods

Participants

Interventions

Outcomes

Notes

Millham 1986

Methods

Participants

Interventions

Outcomes

Notes 
Rowe 1984

Methods

Participants

Interventions

Outcomes

Notes

Rowe 1989

Methods

Participants

Interventions

Outcomes

Notes

Sinclair 2000

Methods

Participants

Interventions

Outcomes

Notes 


\section{Additional tables}

\subsection{OUTCOMES FOR STUDIES WITH MULTIVARIATE ANALYSIS}

\begin{tabular}{|c|c|c|}
\hline Study & Outcome & Results \\
\hline Barth 1994 & Adoption & $\begin{array}{l}\text { 1.Initial placement in a kinship home decreases the odds of } \\
\text { adoption by } 50 \text { percent }(\mathrm{OR}=0.50)\end{array}$ \\
\hline $\begin{array}{l}\text { Belanger } \\
2001\end{array}$ & $\begin{array}{l}\text { Adaptive Behaviors } \\
\text { Psychiatric Disorders }\end{array}$ & $\begin{array}{l}\text { 1.The interaction of type of placement, home index, and } \\
\text { temperament match did not account for more of the variance } \\
\text { in VABS and DSMD scores than did type of placement alone }\end{array}$ \\
\hline $\begin{array}{l}\text { Benedict, Zur } \\
1996\end{array}$ & Institutional Abuse & $\begin{array}{l}\text { 1.Placement in foster care increases the likelihood of } \\
\text { association with maltreatment by } 4.4 \text { times }\end{array}$ \\
\hline Bennett 2001 & $\begin{array}{l}\text { Behavior Problems } \\
\text { Adaptive Behaviors }\end{array}$ & $\begin{array}{l}\text { 1.Children in kinship placements (unstandardized beta }=- \\
\text { 5.596) were significantly less likely to be rated as exhibiting } \\
\text { externalizing behaviors (CBCL scale) } \\
\text { 2.Data did not indicate a statistically significant relationship } \\
\text { between type of placement (unstandardized beta for kinship } \\
\text { care = -3.962) and ratings of internalizing behaviors (CBCL } \\
\text { scale) } \\
\text { 3.Kinship placements (unstandardized beta = 11.834) } \\
\text { associated with higher scores on the adaptive composite } \\
\text { scale of the VABS }\end{array}$ \\
\hline Berrick 1999 & $\begin{array}{l}\text { re-entry } \\
\text { Permanency } \\
\text { "Reunification } \\
\text { "Still in Care }\end{array}$ & $\begin{array}{l}\text { 1.Children in kinship care (AFDC subset) } 2 \%(O R=1.02) \\
\text { more likely to be reunified than children in non-kin foster care } \\
\text { (within four years of placement) } \\
\text { 2.Over four years of placement, non-kinship foster care group } \\
\text { less likely to still be in care as compared to kinship foster care } \\
\text { group } \\
\text { 3.Over four years of placement, non-kinship foster care group } \\
\text { more likely to re-enter care as compared to kinship foster } \\
\text { care group }\end{array}$ \\
\hline Brooks 1998 & Adaptive Behaviors & $\begin{array}{l}\text { 1.Kinship foster care group significantly more likely than } \\
\text { those from non-relative foster care group to demonstrate pro- } \\
\text { social behaviors }\end{array}$ \\
\hline $\begin{array}{l}\text { Chamberlain } \\
2006\end{array}$ & Placement Disruption & $\begin{array}{l}\text { 1.Placement in a non-kin foster home significantly increased } \\
\text { the risk of placement disruption by a factor of just over } 3 \text { (RR } \\
=3.18 \text { ) }\end{array}$ \\
\hline
\end{tabular}




\begin{tabular}{|c|c|c|}
\hline Study & Outcome & Results \\
\hline Clyman 1998 & $\begin{array}{l}\text { Mental Health, } \\
\text { Physican, and } \\
\text { Developmental Service } \\
\text { Utilization }\end{array}$ & $\begin{array}{l}\text { 1.Children in foster care had significantly higher rates of } \\
\text { mental health service utilization } \\
\text { 2.Children in foster care did not have significantly higher rates } \\
\text { of physician and developmental service utilization }\end{array}$ \\
\hline Connell 2006 & $\begin{array}{l}\text { Reunification } \\
\text { Adoption }\end{array}$ & $\begin{array}{l}\text { 1.Children placed in a non-relative foster care home (RR = } \\
\text { 1.16) experienced significantly higher rates of reunification } \\
\text { than children in relative foster homes. } \\
2 . \text { No significant difference between children in relative foster } \\
\text { homes and children in non-relative foster homes ( } R R=1.00) \\
\text { on the probability of exiting care by adoption }\end{array}$ \\
\hline $\begin{array}{l}\text { Connell, Van } \\
2006\end{array}$ & Placement Disruption & $\begin{array}{l}\text { 1.Children placed in non-relative foster care }(R R=3.18) \text { have } \\
\text { statistically significant higher rates of changes in placement } \\
\text { than children in relative foster care }\end{array}$ \\
\hline $\begin{array}{l}\text { Courtney } \\
1995\end{array}$ & re-entry & $\begin{array}{l}\text { 1.Children returned home after leaving kinship care } \\
\text { placements }(R R=0.69) \text { re-entered care at a significantly } \\
\text { lower rate than those discharged from foster home } \\
\text { placements }\end{array}$ \\
\hline $\begin{array}{l}\text { Courtney, } \\
\text { Bar } 1996\end{array}$ & $\begin{array}{l}\text { Reunification } \\
\text { Adoption }\end{array}$ & $\begin{array}{l}\text { 1.Placement with kin }(\mathrm{OR}=1.90) \text { at the time of final discharge } \\
\text { from foster care significantly improved the odds of returning } \\
\text { home or being adopted over unsuccessful discharge }\end{array}$ \\
\hline $\begin{array}{l}\text { Courtney, } \\
\text { Won } 1996\end{array}$ & $\begin{array}{l}\text { Reunification } \\
\text { Adoption }\end{array}$ & $\begin{array}{l}\text { 1.Placement in kinship home associated with lowered } \\
\text { hazards of both reunification }(R R=0.82) \text { and adoption }(R R= \\
0.49) \text { as compared to foster home placements }\end{array}$ \\
\hline $\begin{array}{l}\text { Courtney } \\
1997\end{array}$ & $\begin{array}{l}\text { re-entry } \\
\text { Reunification }\end{array}$ & $\begin{array}{l}\text { 1.No significant difference in rates of reunification based on } \\
\text { child's initial placement in foster home vs. kinship home } \\
\text { 2.Children whose last placement was in kinship care (beta = - } \\
\text {.395) are significantly less likely to return to care than are } \\
\text { children from foster care (beta = -.086) }\end{array}$ \\
\hline Davis 2005 & Relatedness & $\begin{array}{l}\text { 1.Type of placement not found to be predictor of relationship } \\
\text { with caregiver }\end{array}$ \\
\hline Frame 2000 & re-entry & $\begin{array}{l}\text { 1.Children placed with kin }(\mathrm{OR}=.19-.25) \text { just prior to } \\
\text { reunification were about } 80 \% \text { less likely to re-enter care than } \\
\text { those whose last placement was with non-kin }\end{array}$ \\
\hline Frame 2002 & $\begin{array}{l}\text { re-entry } \\
\text { Reunification } \\
\text { Still in Care }\end{array}$ & $\begin{array}{l}\text { 1.Type of placement not found to have statistically significant } \\
\text { relationship with reunification } \\
\text { 2.Type of first placement not significantly associated with re- } \\
\text { entry } \\
\text { 3.No difference found for those children still in care based on } \\
\text { type of first placement }\end{array}$ \\
\hline Fuller 2005 & Recurrence of Abuse & $\begin{array}{l}\text { 1.Children whose initial placement was in kinship foster care } \\
(\mathrm{OR}=9.60) \text {, and whose initial placement was family foster } \\
\text { care }(\mathrm{OR}=2.40) \text { were more likely to experience maltreatment } \\
\text { recurrence, within } 60 \text { days of reunification, than those whose } \\
\text { initial placement was a group home/institution; thus, children } \\
\text { whose initial placement was in kinship foster care were } 4 \\
\text { times more likely to experience maltreatment recurrence, } \\
\text { within } 60 \text { days of reunification, than those whose initial } \\
\text { placement was family foster care }\end{array}$ \\
\hline
\end{tabular}




\begin{tabular}{|c|c|c|}
\hline Study & Outcome & Results \\
\hline $\begin{array}{l}\text { Grogan- } \\
\text { Kaylor } 2000\end{array}$ & Reunification & $\begin{array}{l}\text { 1.Placement into kinship foster home }(R R=1.06) \text { as } \\
\text { compared to foster home with non-relatives increased the } \\
\text { probability that a child would be reunified from foster care } \\
\text { (1998 to } 1995 \text { cohort) }\end{array}$ \\
\hline Holtan 2005 & Behavior Problems & $\begin{array}{l}\text { 1.Non-kinship placement }(\mathrm{OR}=1.90) \text { significantly associated } \\
\text { with scoring within the borderline range on } \mathrm{CBCL} \text { Total } \\
\text { Problems scale }\end{array}$ \\
\hline $\begin{array}{l}\text { Jonson-Reid } \\
2003\end{array}$ & $\begin{array}{l}\text { Recurrence of Abuse } \\
\text { re-entry }\end{array}$ & $\begin{array}{l}\text { 1.Children who exited from care following placement with kin } \\
(\mathrm{RR}=0.82) \text { were significantly less likely than children who } \\
\text { exited from foster care to return for a subsequent report } \\
\text { 2.Child's final placement with kin }(R R=0.66) \text { associated with } \\
\text { decrease in risk of re-entry }\end{array}$ \\
\hline Leslie 2000 & $\begin{array}{l}\text { Mental Health Service } \\
\text { Utilization }\end{array}$ & $\begin{array}{l}\text { 1.Children placed in non-relative foster care had significantly } \\
\text { higher numbers of outpatient mental health visits compared to } \\
\text { those residing in kin only (rate estimate }=0.57 \text { ) }\end{array}$ \\
\hline $\begin{array}{l}\text { McMillen } \\
2004\end{array}$ & $\begin{array}{l}\text { Mental Health Service } \\
\text { Utilization }\end{array}$ & $\begin{array}{l}\text { 1.Kinship care significantly associated with current outpatient } \\
\text { therapy services; children in kinship care }(\mathrm{OR}=0.39) \text { less } \\
\text { likely to utilize outpatient therapy services than non-kin foster } \\
\text { care }\end{array}$ \\
\hline $\begin{array}{l}\text { McMillen } \\
2005\end{array}$ & Psychiatric Disorders & $\begin{array}{l}\text { 1.No significant differences in rates of past year psychiatric } \\
\text { disorders (any disorder) based on living situation (kinship } \\
\text { care [OR }=0.87] \text { vs. non-kin family foster care) }\end{array}$ \\
\hline $\begin{array}{l}\text { Metzger } \\
1997\end{array}$ & Well Being & $\begin{array}{l}\text { 1.Placement type remained the strongest variable in } \\
\text { explaining the variability in child well-being as measured by } \\
\text { the Personal Attribute Inventory for Children }\end{array}$ \\
\hline Shin 2003 & Test Scores & $\begin{array}{l}\text { 1.Adolescents placed in relative foster care }(\text { beta }=.24) \\
\text { showed significantly higher scores on reading skills than } \\
\text { those in non-kin foster care }\end{array}$ \\
\hline Smith 2003 & Still in Care & $\begin{array}{l}\text { 1.Compared to children in adoptive placements, children in } \\
\text { kinship care placements were } 72 \% \text { less likely }(\mathrm{HR}=0.28) \text { to } \\
\text { exit care, children in non-relative placements were } 52 \% \text { less } \\
\text { likely (HR }=.48 \text { ) to exit and children in institutional or other } \\
\text { placement types were } 59 \% \text { less likely (HR }=.41 \text { ) to exit care; } \\
\text { thus, children in non-relative placement are } 1.7 \% \text { more likely } \\
\text { to exit care than children in kinship placement }\end{array}$ \\
\hline $\begin{array}{l}\text { Surbeck } \\
2000\end{array}$ & Behavior Problems & $\begin{array}{l}\text { 1.The difference in behavior problems by placement type was } \\
\text { not maintained when other determinants of child behavior } \\
\text { were included in the specification of the model }\end{array}$ \\
\hline Testa 2001 & $\begin{array}{l}\text { Placement Disruption } \\
\text { Permanency } \\
\text { "Adoption } \\
\text { "Guardianship }\end{array}$ & $\begin{array}{l}\text { 1.At placement start, kinship care is } 86 \% \text { to } 82 \% \text { less prone } \\
\text { to disruption than non-related foster care (cohort samples); } \\
\text { placement with relatives } 67 \% \text { less likely to disrupt from the } \\
\text { start than placements into non-related foster homes (matched } \\
\text { cross sectional sample) }\end{array}$ \\
\hline Vogel 1999 & Length of Placement & $\begin{array}{l}\text { 1.Children in caretaker placements (beta }=-1.22 \text { ) spent } \\
\text { significantly more time in care than their counterparts }\end{array}$ \\
\hline
\end{tabular}




\begin{tabular}{|c|c|c|}
\hline Study & Outcome & Results \\
\hline Wells 1999 & $\begin{array}{l}\text { re-entry } \\
\text { Reunification }\end{array}$ & $\begin{array}{l}\text { 1.Rate of reunification did not differ between children placed } \\
\text { in kinship and non-relative family foster care }(R R=0.94) \\
\text { 2.Children in non-relative foster care }(R R=3.26) \text { re-entered } \\
\text { at rate } 226 \% \text { faster than children whose last placement was } \\
\text { kinship foster care }\end{array}$ \\
\hline Zima 2000 & $\begin{array}{l}\text { Behavior } \\
\text { Problems/Adaptive } \\
\text { Behaviors } \\
\text { Educational Attainment }\end{array}$ & $\begin{array}{l}\text { 1.No significant difference between non-kinship family foster } \\
\text { home and kinship family foster home on CBCL Total } \\
\text { Problems or Total Competence scale } \\
\text { 2.No significant difference between non-kinship family foster } \\
\text { home and kinship family foster home on measure of } \\
\text { educational attainment }\end{array}$ \\
\hline $\begin{array}{l}\text { Zimmerman } \\
1998\end{array}$ & Reunification & $\begin{array}{l}\text { 1. Type of placement not directly related to likelihood of family } \\
\text { reunification (kinship placement } \mathrm{HR}=1.07 \text { ) }\end{array}$ \\
\hline Zuravin 1993 & Institutional Abuse & $\begin{array}{l}\text { 1. Regular care homes were } 2.7 \text { times }(\mathrm{OR}) \text { more likely to } \\
\text { have confirmed report of maltreatment than were kinship } \\
\text { homes }\end{array}$ \\
\hline
\end{tabular}

\subsection{OUTCOMES FOR STUDIES WITH BIVARIATE ANALYSIS}

\begin{tabular}{lll}
\hline Study & Outcomes & Results \\
\hline $\begin{array}{l}\text { Berrick, Oth } \\
1994\end{array}$ & $\begin{array}{l}\text { Behavior } \\
\text { Problems }\end{array}$ & $\begin{array}{l}\text { 1.Children in kinship care had a lower mean total score on the } \\
\text { Behavior Problems Index (BPI) than children in foster care }\end{array}$ \\
\hline $\begin{array}{lll}\text { Landsverk } \\
1996\end{array}$ & $\begin{array}{l}\text { Behavior } \\
\text { Problems }\end{array}$ & 1.Differences between two groups not statistically different on CBCL \\
\hline Metzger 1997 & $\begin{array}{l}\text { Length of } \\
\text { Stay }\end{array}$ & $\begin{array}{l}\text { 1.Children placed in traditional foster homes had longer lengths of } \\
\text { stay than children placed in kinship foster homes }\end{array}$ \\
\hline Mosek 2001 & Well Being & $\begin{array}{l}\text { 1.The self-concept of adolescents growing up with kin foster families } \\
\text { is higher than the self-concept of adolescents in non-relative care }\end{array}$ \\
\hline $\begin{array}{l}\text { Scannapieco } \\
1997\end{array}$ & $\begin{array}{l}\text { Length of } \\
\text { Placement }\end{array}$ & $\begin{array}{l}\text { 1.Children in kinship care differ significantly from children in traditional } \\
\text { foster care on length of time in care, with kinship care reporting } \\
\text { significantly higher lengths of placement }\end{array}$ \\
\hline Sripathy 2004 & $\begin{array}{l}\text { Behavior } \\
\text { Problems } \\
\text { Adaptive } \\
\text { Behaviors }\end{array}$ & $\begin{array}{l}\text { 1.No significant differences found between the two types of care } \\
\text { (kinship and non-kinship children) on CBCL Total Problems and Total } \\
\text { Competence scales }\end{array}$ \\
\hline Zimmerman & $\begin{array}{l}\text { Length of } \\
\text { Stay } \\
\text { re-entry }\end{array}$ & $\begin{array}{l}\text { 1.Children in non-kinship foster placements had a much shorter } \\
\text { median length of stay than children in kinship placements } \\
\text { 2.No significant difference in re-entry rates between children who } \\
\text { were only in non-kinship foster placements and children in kinship } \\
\text { care }\end{array}$ \\
\hline & &
\end{tabular}




\subsection{QUALITY ASSESSMENT RATINGS}

\begin{tabular}{|c|c|c|c|c|c|}
\hline Study & $\begin{array}{l}\text { Selection } \\
\text { Bias }\end{array}$ & $\begin{array}{l}\text { Performance } \\
\text { Bias }\end{array}$ & $\begin{array}{l}\text { Detection } \\
\text { Bias }\end{array}$ & $\begin{array}{l}\text { Report } \\
\text { Bias }\end{array}$ & $\begin{array}{l}\text { Attrition } \\
\text { Bias }\end{array}$ \\
\hline Barth 1994 & Moderate & Moderate & Moderate & Moderate & Low \\
\hline Belanger 2001 & Low & Moderate & Moderate & Moderate & Moderate \\
\hline Benedict, Zur 1996 & Moderate & Moderate & Low & Moderate & Low \\
\hline Bennett 2001 & Moderate & Moderate & Moderate & Low & Low \\
\hline Berrick 1997 & Moderate & Low & Moderate & Moderate & Moderate \\
\hline Berrick 1999 & Moderate & Moderate & Moderate & Moderate & Low \\
\hline Berrick, Oth 1994 & Moderate & High & High & Low & Moderate \\
\hline Bilaver 1999 & High & Moderate & Moderate & Moderate & Low \\
\hline Brooks 1998 & Moderate & High & Moderate & Moderate & Moderate \\
\hline Chamberlain 2006 & Moderate & Moderate & Moderate & Moderate & Low \\
\hline Chapman 2004 & High & Moderate & Moderate & Moderate & Moderate \\
\hline Chew 1998 & High & Moderate & Moderate & Low & High \\
\hline Christopher 1998 & High & Moderate & Moderate & Moderate & Moderate \\
\hline Clyman 1998 & Low & Moderate & High & Moderate & Moderate \\
\hline Cole 2006 & Moderate & Moderate & Moderate & Moderate & Moderate \\
\hline Connell 2006 & Moderate & Moderate & Moderate & Moderate & Moderate \\
\hline Connell, Van 2006 & Moderate & Moderate & Moderate & Moderate & Moderate \\
\hline Courtney 1995 & Moderate & Moderate & Moderate & Moderate & Low \\
\hline Courtney 1997 & Moderate & Moderate & Moderate & Moderate & Low \\
\hline Courtney, Bar 1996 & Moderate & Moderate & Moderate & Moderate & Low \\
\hline Courtney, Nee 1997 & High & Moderate & Moderate & Moderate & Low \\
\hline Courtney, Won 1996 & Moderate & Moderate & Moderate & Moderate & Low \\
\hline Davis 2005 & Moderate & Moderate & Moderate & Moderate & Moderate \\
\hline Frame 2000 & Moderate & Moderate & Moderate & Moderate & Moderate \\
\hline Frame 2002 & Moderate & Moderate & Moderate & Moderate & Low \\
\hline Fuller 2005 & Moderate & Moderate & Moderate & Moderate & Moderate \\
\hline Grogan-Kaylor 2000 & Moderate & Moderate & Moderate & Moderate & Low \\
\hline Harris 2003 & High & Moderate & Moderate & Low & Low \\
\hline Holtan 2005 & Low & Low & Moderate & Low & Moderate \\
\hline Iglehart 1994 & High & Moderate & Moderate & Moderate & Low \\
\hline Iglehart 1995 & High & Moderate & Moderate & Moderate & Moderate \\
\hline Jenkins 2002 & High & High & Low & Low & Low \\
\hline
\end{tabular}




\begin{tabular}{|c|c|c|c|c|c|}
\hline Study & $\begin{array}{l}\text { Selection } \\
\text { Bias }\end{array}$ & $\begin{array}{l}\text { Performance } \\
\text { Bias }\end{array}$ & $\begin{array}{l}\text { Detection } \\
\text { Bias }\end{array}$ & $\begin{array}{l}\text { Report } \\
\text { Bias }\end{array}$ & $\begin{array}{l}\text { Attrition } \\
\text { Bias }\end{array}$ \\
\hline Jones-Karena 1998 & High & Moderate & Moderate & Low & Low \\
\hline Jonson-Reid 2003 & Moderate & Moderate & Moderate & Moderate & Low \\
\hline Landsverk 1996 & High & Moderate & Moderate & Low & Moderate \\
\hline Leslie 2000 & Moderate & Moderate & Moderate & Moderate & Moderate \\
\hline Mclntosh 2002 & Moderate & Moderate & Moderate & Moderate & Moderate \\
\hline McMillen 2004 & Moderate & Moderate & Moderate & Low & Moderate \\
\hline McMillen 2005 & Moderate & Moderate & Moderate & Low & Moderate \\
\hline Metzger 1997 & Low & Low & High & Moderate & Moderate \\
\hline Mosek 2001 & Moderate & Moderate & Moderate & Low & Moderate \\
\hline Rudenberg 1990 & Moderate & Moderate & Moderate & Low & Moderate \\
\hline Sallnas 2004 & High & Moderate & Moderate & Moderate & Moderate \\
\hline Scannapieco 1997 & High & High & Low & Low & Low \\
\hline Shin 2003 & Moderate & Moderate & Moderate & Low & Moderate \\
\hline Sivright 2004 & Moderate & Low & Moderate & Moderate & Moderate \\
\hline Smith 2002 & High & Moderate & Moderate & Moderate & Moderate \\
\hline Smith 2003 & Moderate & Moderate & Moderate & Moderate & Low \\
\hline Sripathy 2004 & Moderate & Moderate & Moderate & Moderate & Moderate \\
\hline Strijker 2003 & High & Moderate & High & Low & Moderate \\
\hline Surbeck 2000 & Moderate & Moderate & Moderate & Moderate & Low \\
\hline $\begin{array}{l}\text { Tarren-Sweeney } \\
2005\end{array}$ & High & Moderate & Moderate & Low & High \\
\hline Testa 1999 & High & Moderate & Moderate & Moderate & Low \\
\hline Testa 2001 & Low & Moderate & Moderate & Moderate & Low \\
\hline Timmer 2004 & Moderate & Moderate & Moderate & Low & Moderate \\
\hline Tompkins Jr 2003 & Moderate & Moderate & Moderate & Moderate & Moderate \\
\hline Vogel 1999 & Moderate & Moderate & Moderate & Moderate & Moderate \\
\hline Wells 1999 & Moderate & Moderate & Moderate & Moderate & Low \\
\hline Wilson 1999 & High & Moderate & Moderate & Low & Moderate \\
\hline Zima 2000 & Moderate & Moderate & Moderate & Moderate & Moderate \\
\hline Zimmerman 1998 & Moderate & Moderate & Moderate & Moderate & Moderate \\
\hline Zuravin 1999 & Moderate & Moderate & Low & Low & Low \\
\hline
\end{tabular}




\subsection{METHODS FOR FUTURE UPDATES}

\begin{tabular}{ll}
\hline Section & Methods \\
\hline $\begin{array}{l}\text { Search } \\
\text { Strategy }\end{array}$ & $\begin{array}{l}\text { Search Child Welfare Information Gateway, National Data Archive on Child Abuse and } \\
\text { Neglect, and System for Information on Grey Literature in Europe (OpenSIGLE). }\end{array}$ \\
\hline $\begin{array}{l}\text { Search } \\
\text { Strategy }\end{array}$ & $\begin{array}{l}\text { Search the websites of international child welfare organizations, University libraries, and } \\
\text { State departments to identify governmental and non-governmental reports and texts. }\end{array}$ \\
\hline $\begin{array}{l}\text { Selection of } \\
\text { Trials }\end{array}$ & $\begin{array}{l}\text { If consensus regarding future selection decisions cannot be reached through discussion } \\
\text { with a third reviewer, it will be resolved by appeal to external advisers. }\end{array}$ \\
\hline $\begin{array}{l}\text { Sensitivity } \\
\text { Analyses }\end{array}$ & $\begin{array}{l}\text { Should sufficient data exist, the following planned comparisons will be analyzed: } \\
\text { Studies that use matching or covariates will be compared to studies that do not control } \\
\text { for confounders. Studies with outcomes measured by caregiver or teacher reports will } \\
\text { be compared to studies with outcomes measured by self-reports. Studies with low } \\
\text { overall or differential attrition will be compared to studies with high overall or differential } \\
\text { attrition. }\end{array}$ \\
\hline $\begin{array}{l}\text { Subgroup } \\
\text { Analyses }\end{array}$ & $\begin{array}{l}\text { Should sufficient data exist, we plan subgroup analyses to examine different effects of } \\
\text { the intervention (if any) by gender, ethnicity, and age at placement. }\end{array}$ \\
\hline
\end{tabular}

\subsection{PARTICIPANT BASELINE CHARACTERISTICS}

\begin{tabular}{|c|c|c|c|c|c|}
\hline Study & $\begin{array}{l}\text { Age at } \\
\text { Placement }\end{array}$ & Gender & Ethnicity & $\begin{array}{l}\text { Removal } \\
\text { Reason }\end{array}$ & Urbanicity \\
\hline \multicolumn{6}{|l|}{ Barth 1994} \\
\hline Belanger 2002 & & $\begin{array}{l}\text { Female }(\mathrm{K}) \text { - } \\
59 \% \\
\text { Female }(\mathrm{F}) \text { - } \\
59 \%\end{array}$ & $\begin{array}{l}\text { Black (O) - } \\
63 \% \\
\text { Black (K) - } \\
68 \% \\
\text { Black (F) - } \\
61 \% \\
\text { Hispanic (O) - } \\
33 \% \\
\text { Hispanic (K) - } \\
32 \% \\
\text { Hispanic (F) - } \\
33 \%\end{array}$ & & \\
\hline Benedict 1996a & & $\begin{array}{l}\text { Female }(0) \text { - } \\
51 \%\end{array}$ & $\begin{array}{l}\text { Black (O) - } \\
84 \%\end{array}$ & $\begin{array}{l}\text { Neglect (0) - } \\
27 \%\end{array}$ & $\begin{array}{l}\text { Urban }(0) \\
100 \%\end{array}$ \\
\hline Bennett 2000 & (0) - 3.4 years & $\begin{array}{l}\text { Female }(0) \text { - } \\
41 \%\end{array}$ & $\begin{array}{l}\text { Black (0) - } \\
56 \% \\
\text { Hispanic (O) - } \\
12 \%\end{array}$ & $\begin{array}{l}\text { Neglect (0) - } \\
92 \%\end{array}$ & \\
\hline Berrick 1997 & $\begin{array}{l}\text { (K) - } 7 \text { years } \\
(\mathrm{F})-7 \text { years }\end{array}$ & $\begin{array}{l}\text { Female }(0) \text { - } \\
62 \%\end{array}$ & $\begin{array}{l}\text { Black (O) - } \\
19 \% \\
\text { Hispanic (O) - } \\
32 \%\end{array}$ & & \\
\hline
\end{tabular}

Berrick 1999 


\begin{tabular}{|c|c|c|c|c|c|}
\hline Study & $\begin{array}{l}\text { Age at } \\
\text { Placement }\end{array}$ & Gender & Ethnicity & $\begin{array}{l}\text { Removal } \\
\text { Reason }\end{array}$ & Urbanicity \\
\hline Berrick, Oth 1994 & & $\begin{array}{l}\text { Female }(\mathrm{K}) \text { - } \\
52 \% \\
\text { Female }(\mathrm{F}) \text { - } \\
54 \%\end{array}$ & $\begin{array}{l}\text { Black (K) - } \\
46 \% \\
\text { Black (F) - } \\
28 \% \\
\text { Hispanic (K) - } \\
14 \% \\
\text { Hispanic (F) - } \\
22 \%\end{array}$ & & \\
\hline \multicolumn{6}{|l|}{ Bilaver 1999} \\
\hline Brooks 1998 & & $\begin{array}{l}\text { Female }(\mathrm{K}) \text { - } \\
52 \% \\
\text { Female }(\mathrm{F}) \text { - } \\
55 \%\end{array}$ & $\begin{array}{l}\text { Black (K) - } \\
47 \% \\
\text { Black (F) - } \\
29 \% \\
\text { Hispanic (K) - } \\
14 \% \\
\text { Hispanic (F) - } \\
21 \%\end{array}$ & & \\
\hline Chamberlain 2006 & & $\begin{array}{l}\text { Female (0) - } \\
53 \%\end{array}$ & $\begin{array}{l}\text { Black (0) - } \\
19 \% \\
\text { Hispanic (0) - } \\
31 \%\end{array}$ & & \\
\hline Chapman 2004 & & $\begin{array}{l}\text { Female (0) - } \\
51 \%\end{array}$ & $\begin{array}{l}\text { Black }(0) \text { - } \\
37 \% \\
\text { Hispanic }(0) \text { - } \\
17 \%\end{array}$ & & \\
\hline Chew 1998 & & $\begin{array}{l}\text { Female (0) - } \\
44 \%\end{array}$ & $\begin{array}{l}\text { Black }(0) \text { - } \\
62 \% \\
\text { Hispanic }(0) \text { - } \\
3 \%\end{array}$ & $\begin{array}{l}\text { Neglect }(0) \text { - } \\
100 \%\end{array}$ & \\
\hline Christopher 1998 & (0) - 9.5 years & $\begin{array}{l}\text { Female (0) - } \\
71 \%\end{array}$ & $\begin{array}{l}\text { Black (0) - } \\
30 \% \\
\text { Hispanic (0) - } \\
26 \%\end{array}$ & $\begin{array}{l}\text { Neglect }(0) \text { - } \\
41 \%\end{array}$ & \\
\hline Clyman 1998 & & $\begin{array}{l}\text { Female }(K) \text { - } \\
46 \% \\
\text { Female }(F)- \\
46 \%\end{array}$ & $\begin{array}{l}\text { Black (K) - } \\
73 \% \\
\text { Black (F) - } \\
65 \%\end{array}$ & & \\
\hline Cole 2006 & $\begin{array}{l}(\mathrm{K}) \text { - } 1 \text { year } \\
(\mathrm{F})-1.1 \text { years }\end{array}$ & $\begin{array}{l}\text { Female }(\mathrm{K}) \text { - } \\
58 \% \\
\text { Female }(\mathrm{F}) \text { - } \\
53 \%\end{array}$ & $\begin{array}{l}\text { Black (K) - } \\
83 \% \\
\text { Black (F) - } \\
94 \%\end{array}$ & & \\
\hline Connell 2006a & (0) - 9.4 years & $\begin{array}{l}\text { Female (0) - } \\
45 \%\end{array}$ & $\begin{array}{l}\text { Black (0) - } \\
18 \% \\
\text { Hispanic (0) - } \\
16 \%\end{array}$ & $\begin{array}{l}\text { Neglect }(0) \text { - } \\
40 \%\end{array}$ & \\
\hline
\end{tabular}




\begin{tabular}{|c|c|c|c|c|c|}
\hline Study & $\begin{array}{l}\text { Age at } \\
\text { Placement }\end{array}$ & Gender & Ethnicity & $\begin{array}{l}\text { Removal } \\
\text { Reason }\end{array}$ & Urbanicity \\
\hline Connell 2006b & & $\begin{array}{l}\text { Female (0) - } \\
45 \%\end{array}$ & $\begin{array}{l}\text { Black }(0) \text { - } \\
18 \% \\
\text { Hispanic }(0) \text { - } \\
16 \%\end{array}$ & $\begin{array}{l}\text { Neglect (0) - } \\
40 \%\end{array}$ & \\
\hline Courtney 1995 & & $\begin{array}{l}\text { Female (0) - } \\
53 \%\end{array}$ & $\begin{array}{l}\text { Black (0) - } \\
26 \% \\
\text { Hispanic (0) - } \\
27 \%\end{array}$ & & \\
\hline Courtney 1996a & & $\begin{array}{l}\text { Female (0) - } \\
64 \%\end{array}$ & $\begin{array}{l}\text { Black (0) - } \\
31 \% \\
\text { Hispanic (O) - } \\
19 \%\end{array}$ & & \\
\hline Courtney 1996b & & $\begin{array}{l}\text { Female (0) - } \\
53 \%\end{array}$ & $\begin{array}{l}\text { Black (0) -31\% } \\
\text { Hispanic (O) - } \\
23 \%\end{array}$ & $\begin{array}{l}\text { Neglect }(0) \text { - } \\
67 \%\end{array}$ & $\begin{array}{l}\text { Urban (0) - } \\
94 \% \\
\text { Rural (0) - } 6 \%\end{array}$ \\
\hline Courtney 1997a & & $\begin{array}{l}\text { Female (0) - } \\
50 \%\end{array}$ & $\begin{array}{l}\text { Black (0) - } \\
35 \% \\
\text { Hispanic (0) - } \\
23 \%\end{array}$ & $\begin{array}{l}\text { Neglect (0) - } \\
72 \%\end{array}$ & $\begin{array}{l}\text { Urban (0) - } \\
40 \% \\
\text { Rural (0) - } 6 \%\end{array}$ \\
\hline \multicolumn{6}{|l|}{ Courtney 1997b } \\
\hline Davis 2005 & $\begin{array}{l}(\mathrm{K})-8.8 \text { years } \\
(\mathrm{F})-8.9 \text { years }\end{array}$ & $\begin{array}{l}\text { Female }(\mathrm{O}) \text { - } \\
40 \% \\
\text { Female }(\mathrm{K}) \text { - } \\
12 \% \\
\text { Female }(\mathrm{F}) \text { - } \\
50 \%\end{array}$ & $\begin{array}{l}\text { Black (0) - } \\
100 \%\end{array}$ & $\begin{array}{l}\text { Neglect (O) - } \\
77 \% \\
\text { Neglect (K) - } \\
38 \% \\
\text { Neglect (F) - } \\
91 \%\end{array}$ & \\
\hline \multicolumn{6}{|l|}{ Frame 2000} \\
\hline Frame 2002 & & $\begin{array}{l}\text { Female (0) - } \\
51 \%\end{array}$ & $\begin{array}{l}\text { Black (0) - } \\
37 \% \\
\text { Hispanic (0) - } \\
26 \%\end{array}$ & $\begin{array}{l}\text { Neglect }(0) \text { - } \\
82 \%\end{array}$ & \\
\hline Fuller 2005 & & $\begin{array}{l}\text { Female (0) - } \\
53 \%\end{array}$ & $\begin{array}{l}\text { Black (0) - } \\
45 \% \\
\text { Hispanic (0) - } \\
9 \%\end{array}$ & $\begin{array}{l}\text { Neglect }(0) \text { - } \\
58 \%\end{array}$ & \\
\hline $\begin{array}{l}\text { Grogan-Kaylor } \\
2000\end{array}$ & & $\begin{array}{l}\text { Female (0) - } \\
54 \%\end{array}$ & $\begin{array}{l}\text { Black (0) - } \\
29 \% \\
\text { Hispanic (0) - } \\
26 \%\end{array}$ & $\begin{array}{l}\text { Neglect }(0) \text { - } \\
66 \%\end{array}$ & $\begin{array}{l}\text { Urban (0) - } \\
37 \% \\
\text { Rural (0) - } 6 \%\end{array}$ \\
\hline Harris 2003 & & $\begin{array}{l}\text { Female (0) - } \\
55 \%\end{array}$ & $\begin{array}{l}\text { Black (0) - } \\
55 \%\end{array}$ & $\begin{array}{l}\text { Neglect (0) - } \\
63 \%\end{array}$ & \\
\hline Holtan 2005 & $\begin{array}{l}(\mathrm{K})-3.8 \text { years } \\
(\mathrm{F})-3.8 \text { years }\end{array}$ & $\begin{array}{l}\text { Female }(\mathrm{K}) \text { - } \\
45 \% \\
\text { Female (F) - } \\
43 \%\end{array}$ & & & \\
\hline
\end{tabular}




\begin{tabular}{|c|c|c|c|c|c|}
\hline Study & $\begin{array}{l}\text { Age at } \\
\text { Placement }\end{array}$ & Gender & Ethnicity & $\begin{array}{l}\text { Removal } \\
\text { Reason }\end{array}$ & Urbanicity \\
\hline Iglehart 1994 & & $\begin{array}{l}\text { Female }(0) \text { - } \\
62 \% \\
\text { Female }(\mathrm{K}) \text { - } \\
34 \%\end{array}$ & $\begin{array}{l}\text { Black (O) - } \\
43 \% \\
\text { Black (K) - } \\
44 \% \\
\text { Hispanic (O) - } \\
28 \% \\
\text { Hispanic (K) - } \\
28 \%\end{array}$ & $\begin{array}{l}\text { Neglect (K) - } \\
62 \% \\
\text { Neglect (F) - } \\
50 \%\end{array}$ & \\
\hline Iglehart 1995 & & $\begin{array}{l}\text { Female }(\mathrm{K}) \text { - } \\
52 \% \\
\text { Female }(\mathrm{F}) \text { - } \\
75 \%\end{array}$ & $\begin{array}{l}\text { Black (K) - } \\
69 \% \\
\text { Black (F) - } \\
41 \% \\
\text { Hispanic (K) - } \\
10 \% \\
\text { Hispanic (F) - } \\
19 \%\end{array}$ & & \\
\hline Jenkins 2002 & & $\begin{array}{l}\text { Female (0) - } \\
49 \%\end{array}$ & $\begin{array}{l}\text { Black (0) - } \\
45 \% \\
\text { Hispanic (0) - } \\
52 \%\end{array}$ & & $\begin{array}{l}\text { Urban (0) - } \\
100 \%\end{array}$ \\
\hline $\begin{array}{l}\text { Jones-Karena } \\
1998\end{array}$ & & $\begin{array}{l}\text { Female (0) - } \\
50 \%\end{array}$ & $\begin{array}{l}\text { Black (0) - } \\
60 \%\end{array}$ & $\begin{array}{l}\text { Neglect (0) - } \\
47 \%\end{array}$ & \\
\hline Jonson-Reid 2003 & & $\begin{array}{l}\text { Female (0) - } \\
55 \%\end{array}$ & & $\begin{array}{l}\text { Neglect (0) - } \\
40 \%\end{array}$ & \\
\hline Landsverk 1996 & & $\begin{array}{l}\text { Female }(K) \text { - } \\
49 \% \\
\text { Female }(F) \text { - } \\
59 \%\end{array}$ & & $\begin{array}{l}\text { Neglect (K) - } \\
80 \% \\
\text { Neglect (F) - } \\
68 \%\end{array}$ & \\
\hline Leslie 2000a & & $\begin{array}{l}\text { Female (0) - } \\
55 \%\end{array}$ & $\begin{array}{l}\text { Black }(0) \text { - } \\
28 \% \\
\text { Hispanic }(0) \text { - } \\
23 \%\end{array}$ & $\begin{array}{l}\text { Neglect (0) - } \\
68 \%\end{array}$ & \\
\hline Mcintosh 2002 & & $\begin{array}{l}\text { Female }(0) \text { - } \\
46 \% \\
\text { Female (K) - } \\
51 \% \\
\text { Female (F) - } \\
43 \%\end{array}$ & $\begin{array}{l}\text { Black (O) - } \\
45 \% \\
\text { Black (K) - } \\
49 \% \\
\text { Black (F) - } \\
43 \% \\
\text { Hispanic (O) - } \\
38 \% \\
\text { Hispanic (K) - } \\
36 \% \\
\text { Hispanic (F) - } \\
40 \%\end{array}$ & $\begin{array}{l}\text { Neglect (O) - } \\
60 \% \\
\text { Neglect (K) - } \\
59 \% \\
\text { Neglect (F) - } \\
61 \%\end{array}$ & \\
\hline McMillen 2004 & (0) -10.9 years & $\begin{array}{l}\text { Female (0) - } \\
56 \%\end{array}$ & $\begin{array}{l}\text { Black }(0) \text { - } \\
51 \% \\
\text { Hispanic }(0) \text { - } \\
1 \%\end{array}$ & $\begin{array}{l}\text { Neglect (0) - } \\
46 \%\end{array}$ & \\
\hline
\end{tabular}




\begin{tabular}{|c|c|c|c|c|c|}
\hline Study & $\begin{array}{l}\text { Age at } \\
\text { Placement }\end{array}$ & Gender & Ethnicity & $\begin{array}{l}\text { Removal } \\
\text { Reason }\end{array}$ & Urbanicity \\
\hline McMillen 2005 & (0) - 10.6 years & $\begin{array}{l}\text { Female (0) - } \\
56 \%\end{array}$ & $\begin{array}{l}\text { Black }(0) \text { - } \\
52 \% \\
\text { Hispanic }(0) \text { - } \\
1 \%\end{array}$ & $\begin{array}{l}\text { Neglect }(0) \text { - } \\
48 \%\end{array}$ & \\
\hline Metzger 1997 & & $\begin{array}{l}\text { Female }(\mathrm{K}) \text { - } \\
56 \% \\
\text { Female }(\mathrm{F}) \text { - } \\
49 \%\end{array}$ & $\begin{array}{l}\text { Black (K) - } \\
61 \% \\
\text { Black (F) - } \\
58 \% \\
\text { Hispanic (K) - } \\
27 \% \\
\text { Hispanic (F) - } \\
15 \%\end{array}$ & $\begin{array}{l}\text { Neglect (K) - } \\
87 \% \\
\text { Neglect (F) - } \\
71 \%\end{array}$ & \\
\hline Mosek 2001 & & $\begin{array}{l}\text { Female }(0) \text { - } \\
100 \%\end{array}$ & & & \\
\hline Rudenberg 1991 & & $\begin{array}{l}\text { Female }(\mathrm{K}) \text { - } \\
50 \% \\
\text { Female }(\mathrm{F}) \text { - } \\
50 \%\end{array}$ & $\begin{array}{l}\text { Black (K) - } \\
14 \% \\
\text { Black (F) - } \\
29 \% \\
\text { Hispanic (K) - } \\
14 \% \\
\text { Hispanic (F) - } \\
11 \%\end{array}$ & & \\
\hline \multicolumn{6}{|l|}{ Sallnas 2004} \\
\hline \multicolumn{6}{|l|}{ Scannapieco 1997} \\
\hline Shin 2003 & (0) - 9.5 years & $\begin{array}{l}\text { Female (0) - } \\
51 \%\end{array}$ & $\begin{array}{l}\text { Black }(0) \text { - } \\
64 \% \\
\text { Hispanic }(0) \text { - } \\
4 \%\end{array}$ & & \\
\hline Sivright 2004 & $\begin{array}{l}(\mathrm{K})-4.7 \text { years } \\
(\mathrm{F})-3.5 \text { years }\end{array}$ & $\begin{array}{l}\text { Female }(0) \text { - } \\
53 \% \\
\text { Female }(\mathrm{K}) \text { - } \\
51 \% \\
\text { Female (F) - } \\
54 \%\end{array}$ & $\begin{array}{l}\text { Black (O) - } \\
52 \% \\
\text { Black (K) - } \\
63 \% \\
\text { Black (F) - } \\
54 \% \\
\text { Hispanic (O) - } \\
34 \% \\
\text { Hispanic (K) - } \\
35 \% \\
\text { Hispanic (F) - } \\
40 \%\end{array}$ & $\begin{array}{l}\text { Neglect }(0) \text { - } \\
78 \% \\
\text { Neglect }(\mathrm{K}) \text { - } \\
82 \% \\
\text { Neglect (F) - } \\
75 \%\end{array}$ & \\
\hline Smith 2002 & & $\begin{array}{l}\text { Female (K) - } \\
47 \% \\
\text { Female (F) - } \\
36 \%\end{array}$ & $\begin{array}{l}\text { Black (K) - } \\
80 \% \\
\text { Black (F) - } \\
61 \%\end{array}$ & & \\
\hline Smith 2003 & & $\begin{array}{l}\text { Female (0) - } \\
48 \%\end{array}$ & $\begin{array}{l}\text { Black }(0) \text { - } \\
48 \% \\
\text { Hispanic }(0) \text { - } \\
10 \%\end{array}$ & $\begin{array}{l}\text { Neglect (0) - } \\
56 \%\end{array}$ & \\
\hline
\end{tabular}




\begin{tabular}{|c|c|c|c|c|c|}
\hline Study & $\begin{array}{l}\text { Age at } \\
\text { Placement }\end{array}$ & Gender & Ethnicity & $\begin{array}{l}\text { Removal } \\
\text { Reason }\end{array}$ & Urbanicity \\
\hline Sripathy 2004 & & $\begin{array}{l}\text { Female (0) - } \\
44 \%\end{array}$ & $\begin{array}{l}\text { Black }(0) \text { - } \\
70 \% \\
\text { Hispanic }(0) \text { - } \\
16 \%\end{array}$ & $\begin{array}{l}\text { Neglect (K) - } \\
75 \% \\
\text { Neglect (F) - } \\
45 \%\end{array}$ & $\begin{array}{l}\text { Urban (0) - } \\
100 \%\end{array}$ \\
\hline \multicolumn{6}{|l|}{ Strijker 2003} \\
\hline Surbeck 2000 & & $\begin{array}{l}\text { Female (K) - } \\
56 \% \\
\text { Female (F) - } \\
54 \%\end{array}$ & $\begin{array}{l}\text { Black (K) - } \\
72 \% \\
\text { Black (F) - } \\
41 \% \\
\text { Hispanic (K) - } \\
1 \% \\
\text { Hispanic }(\mathrm{F}) \text { - } \\
1 \%\end{array}$ & & \\
\hline $\begin{array}{l}\text { Tarren-Sweeney } \\
2006\end{array}$ & (0) - 3.5 years & $\begin{array}{l}\text { Female (0) - } \\
49 \%\end{array}$ & & $\begin{array}{l}\text { Neglect (0) - } \\
78 \%\end{array}$ & $\begin{array}{l}\text { Urban (0) - } \\
52 \% \\
\text { Rural (0) - } \\
48 \%\end{array}$ \\
\hline \multicolumn{6}{|l|}{ Testa 1999} \\
\hline Testa 2001 & $\begin{array}{l}(K)-5.4 \text { years } \\
(F)-4.2 \text { years }\end{array}$ & $\begin{array}{l}\text { Female }(\mathrm{K}) \text { - } \\
50 \% \\
\text { Female }(\mathrm{F}) \text { - } \\
51 \%\end{array}$ & $\begin{array}{l}\text { Black (0) - } \\
100 \%\end{array}$ & & \\
\hline Timmer 2004 & & $\begin{array}{l}\text { Female (O) - } \\
36 \% \\
\text { Female (K) - } \\
28 \% \\
\text { Female (F) - } \\
47 \%\end{array}$ & $\begin{array}{l}\text { Black (O) - } \\
39 \% \\
\text { Black (K) - } \\
33 \% \\
\text { Black (F) - } \\
42 \% \\
\text { Hispanic (O) - } \\
20 \% \\
\text { Hispanic (K) - } \\
22 \% \\
\text { Hispanic (F) - } \\
19 \%\end{array}$ & & \\
\hline Tompkins 2003 & & $\begin{array}{l}\text { Female }(0)- \\
50 \% \\
\text { Female }(\mathrm{K}) \text { - } \\
47 \% \\
\text { Female (F) - } \\
53 \%\end{array}$ & $\begin{array}{l}\text { Black (O) - } \\
57 \% \\
\text { Black (K) - } \\
62 \% \\
\text { Black (F) - } \\
55 \% \\
\text { Hispanic (O) - } \\
14 \% \\
\text { Hispanic (K) - } \\
13 \% \\
\text { Hispanic }(0) \text { - } \\
15 \%\end{array}$ & & \\
\hline
\end{tabular}




\begin{tabular}{|c|c|c|c|c|c|c|}
\hline Study & $\begin{array}{l}\text { Age at } \\
\text { Placement }\end{array}$ & Gender & \multicolumn{2}{|c|}{ Ethnicity } & $\begin{array}{l}\text { Removal } \\
\text { Reason }\end{array}$ & Urbanicity \\
\hline Vogel 1999 & (0) - 6.3 years & $\begin{array}{l}\text { Female (0) - } \\
50 \%\end{array}$ & \multicolumn{2}{|c|}{$\begin{array}{l}\text { Black (0) - } \\
83 \% \\
\text { Hispanic (0) - } \\
8 \%\end{array}$} & & \\
\hline Wells 1999 & & $\begin{array}{l}\text { Female (0) - } \\
51 \%\end{array}$ & \multicolumn{2}{|c|}{$\begin{array}{l}\text { Black (0) - } \\
77 \%\end{array}$} & $\begin{array}{l}\text { Neglect (0) - } \\
87 \%\end{array}$ & \\
\hline \multicolumn{7}{|l|}{ Wilson 1999} \\
\hline Zima 2000 & & $\begin{array}{l}\text { Female }(0) \text { - } \\
53 \%\end{array}$ & \multicolumn{2}{|c|}{$\begin{array}{l}\text { Black (0) - } \\
34 \% \\
\text { Hispanic (0) - } \\
38 \%\end{array}$} & & \\
\hline Zimmerman 1998 & $\begin{array}{l}(\mathrm{K})-1.8 \text { years } \\
(\mathrm{F})-1.8 \text { years }\end{array}$ & $\begin{array}{l}\text { Female }(0) \text { - } \\
50 \%\end{array}$ & \multicolumn{2}{|c|}{$\begin{array}{l}\text { Black (0) - } \\
70 \% \\
\text { Hispanic (0) - } \\
26 \%\end{array}$} & $\begin{array}{l}\text { Neglect }(0) \text { - } \\
70 \%\end{array}$ & $\begin{array}{l}\text { Urban }(0)- \\
100 \%\end{array}$ \\
\hline Zuravin 1993 & & & & & & $\begin{array}{l}\text { Urban }(0) \text { - } \\
100 \%\end{array}$ \\
\hline INTI & \multicolumn{5}{|c|}{ INTERVENTION CHARACTERISTICS } & \\
\hline Study & $\begin{array}{l}\text { Kin Placement } \\
\text { Type }\end{array}$ & \multirow{2}{*}{\multicolumn{2}{|c|}{$\begin{array}{l}\text { Placement } \\
\text { Timing }\end{array}$}} & \multicolumn{2}{|c|}{ Length of Stay } & Data Collection \\
\hline Barth 1994 & $\begin{array}{l}\text { Not } \\
\text { Reported/Unclear }\end{array}$ & & & & & Cross-sectional \\
\hline Belanger 2002 & $\begin{array}{l}\text { Not } \\
\text { Reported/Unclear }\end{array}$ & \multicolumn{2}{|c|}{$\begin{array}{l}\text { Not } \\
\text { Reported/Unclear }\end{array}$} & \multicolumn{2}{|c|}{$\begin{array}{l}\text { (K) - OOH - } 29.0 \text { months } \\
\text { (F) - OOH - } 31.0 \text { months }\end{array}$} & Cross-sectional \\
\hline Benedict 1996a & Licensed & \multicolumn{4}{|l|}{ First } & $\begin{array}{l}\text { Longitudinal - } 4 \\
\text { years }\end{array}$ \\
\hline Bennett 2000 & $\begin{array}{l}\text { Not } \\
\text { Reported/Unclear }\end{array}$ & \multicolumn{4}{|c|}{$\begin{array}{l}\text { Not } \\
\text { Reported/Unclear }\end{array}$} & Cross-sectional \\
\hline Berrick 1997 & $\begin{array}{l}\text { Not } \\
\text { Reported/Unclear }\end{array}$ & \multicolumn{2}{|c|}{$\begin{array}{l}\text { Not } \\
\text { Reported/Unclear }\end{array}$} & \multicolumn{2}{|c|}{$\begin{array}{l}(\mathrm{K}) \text { - Placement - } 18.0 \\
\text { months }(\mathrm{F}) \text { - Placement - } \\
18.0 \text { months }\end{array}$} & Cross-sectional \\
\hline Berrick 1999 & $\begin{array}{l}\text { Not } \\
\text { Reported/Unclear }\end{array}$ & \multicolumn{4}{|l|}{ First } & $\begin{array}{l}\text { Longitudinal - up } \\
\text { to } 7 \text { years }\end{array}$ \\
\hline $\begin{array}{l}\text { Berrick, Oth } \\
1994\end{array}$ & $\begin{array}{l}\text { Not } \\
\text { Reported/Unclear }\end{array}$ & \multicolumn{2}{|c|}{$\begin{array}{l}\text { Not } \\
\text { Reported/Unclear }\end{array}$} & \multicolumn{2}{|c|}{$\begin{array}{l}(\mathrm{K}) \text { - Placement - } 39.0 \\
\text { months }(\mathrm{F}) \text { - Placement - } \\
28.0 \text { months }\end{array}$} & Cross-sectional \\
\hline Bilaver 1999 & $\begin{array}{l}\text { Not } \\
\text { Reported/Unclear }\end{array}$ & \multicolumn{4}{|l|}{ Only } & $\begin{array}{l}\text { Longitudinal - } 1 \text { - } \\
2 \text { years }\end{array}$ \\
\hline Brooks 1998 & $\begin{array}{l}\text { Not } \\
\text { Reported/Unlcear }\end{array}$ & \multicolumn{2}{|c|}{$\begin{array}{l}\text { Not } \\
\text { Reported/Unclear }\end{array}$} & \multicolumn{2}{|c|}{$\begin{array}{l}\text { (K) - Placement - } 43.2 \\
\text { months (F) - Placement - } \\
32.4 \text { months }\end{array}$} & Cross-sectional \\
\hline
\end{tabular}




\begin{tabular}{|c|c|c|c|c|}
\hline Study & $\begin{array}{l}\text { Kin Placement } \\
\text { Type }\end{array}$ & $\begin{array}{l}\text { Placement } \\
\text { Timing }\end{array}$ & Length of Stay & Data Collection \\
\hline $\begin{array}{l}\text { Chamberlain } \\
2006\end{array}$ & $\begin{array}{l}\text { Not } \\
\text { Reported/Unclear }\end{array}$ & $\begin{array}{l}\text { Not } \\
\text { Reported/Unclear }\end{array}$ & & $\begin{array}{l}\text { Longitudinal - } 1 \\
\text { year }\end{array}$ \\
\hline Chapman 2004 & $\begin{array}{l}\text { Not } \\
\text { Reported/Unclear }\end{array}$ & $\begin{array}{l}\text { Not } \\
\text { Reported/Unclear }\end{array}$ & $\begin{array}{l}(\mathrm{K}) \text { - Placement - } 12.0 \\
\text { months }(\mathrm{F}) \text { - Placement - } \\
12.0 \text { months }\end{array}$ & Cross-sectional \\
\hline Chew 1998 & $\begin{array}{l}\text { Not } \\
\text { Reported/Unclear }\end{array}$ & $\begin{array}{l}\text { Not } \\
\text { Reported/Unclear }\end{array}$ & & Cross-sectional \\
\hline $\begin{array}{l}\text { Christopher } \\
1998\end{array}$ & $\begin{array}{l}\text { Not } \\
\text { Reported/Unclear }\end{array}$ & Last & & Cross-sectional \\
\hline Clyman 1998 & $\begin{array}{l}\text { Not } \\
\text { Reported/Unclear }\end{array}$ & $\begin{array}{l}\text { Not } \\
\text { Reported/Unclear }\end{array}$ & $\begin{array}{l}\text { (K) - OOH - } 21.2 \text { months } \\
(\mathrm{F})-\mathrm{OOH}-17.5 \text { months }\end{array}$ & Cross-sectional \\
\hline Cole 2006 & $\begin{array}{l}\text { Not } \\
\text { Reported/Unclear }\end{array}$ & First & $\begin{array}{l}\text { (K) - Placement - } 11.0 \\
\text { months }\end{array}$ & Cross-sectional \\
\hline Connell 2006a & $\begin{array}{l}\text { Not } \\
\text { Reported/Unclear }\end{array}$ & First & & $\begin{array}{l}\text { Longitudinal - up } \\
\text { to } 5 \text { years }\end{array}$ \\
\hline Connell 2006b & $\begin{array}{l}\text { Not } \\
\text { Reported/Unclear }\end{array}$ & First & & $\begin{array}{l}\text { Longitudinal - } 5 \\
\text { years }\end{array}$ \\
\hline Courtney 1995 & $\begin{array}{l}\text { Not } \\
\text { Reported/Unclear }\end{array}$ & Last & & $\begin{array}{l}\text { Longitudinal - } 3 \\
\text { years }\end{array}$ \\
\hline $\begin{array}{l}\text { Courtney } \\
1996 a\end{array}$ & $\begin{array}{l}\text { Not } \\
\text { Reported/Unclear }\end{array}$ & Last & & Cross-sectional \\
\hline $\begin{array}{l}\text { Courtney } \\
1996 b\end{array}$ & $\begin{array}{l}\text { Not } \\
\text { Reported/Unclear }\end{array}$ & First & & Cross-sectional \\
\hline $\begin{array}{l}\text { Courtney } \\
1997 a\end{array}$ & $\begin{array}{l}\text { Not } \\
\text { Reported/Unclear }\end{array}$ & $\begin{array}{l}\text { First } \\
\text { (Reunification) } \\
\text { Last (re-entry) }\end{array}$ & & $\begin{array}{l}\text { Longitudinal - } 6 \\
\text { years }\end{array}$ \\
\hline $\begin{array}{l}\text { Courtney } \\
1997 b\end{array}$ & $\begin{array}{l}\text { Not } \\
\text { Reported/Unclear }\end{array}$ & First & & $\begin{array}{l}\text { Longitudinal - } 4 \\
\text { years }\end{array}$ \\
\hline Davis 2005 & $\begin{array}{l}\text { Not } \\
\text { Reported/Unclear }\end{array}$ & $\begin{array}{l}\text { Not } \\
\text { Reported/Unclear }\end{array}$ & $\begin{array}{l}\text { (K) - Placement - } 16.0 \\
\text { months } \\
\text { (K) - OOH - } 80.0 \text { months } \\
\text { (F) - Placement - } 39.0 \\
\text { months } \\
\text { (F) - OOH - } 65.0 \text { months }\end{array}$ & Cross-sectional \\
\hline Frame 2000 & $\begin{array}{l}\text { Not } \\
\text { Reported/Unclear }\end{array}$ & Last & & $\begin{array}{l}\text { Longitudinal - } 4- \\
6 \text { years }\end{array}$ \\
\hline Frame 2002 & $\begin{array}{l}\text { Not } \\
\text { Reported/Unclear }\end{array}$ & First & & $\begin{array}{l}\text { Longitudinal - } \\
3.5-4.5 \text { years }\end{array}$ \\
\hline Fuller 2005 & $\begin{array}{l}\text { Not } \\
\text { Reported/Unclear }\end{array}$ & First & & Cross-sectional \\
\hline $\begin{array}{l}\text { Grogan-Kaylor } \\
2000\end{array}$ & $\begin{array}{l}\text { Not } \\
\text { Reported/Unclear }\end{array}$ & First & & Cross-sectional \\
\hline Harris 2003 & $\begin{array}{l}\text { Not } \\
\text { Reported/Unclear }\end{array}$ & $\begin{array}{l}\text { Not } \\
\text { Reported/Unclear }\end{array}$ & & Cross-sectional \\
\hline
\end{tabular}




\begin{tabular}{|c|c|c|c|c|}
\hline Study & $\begin{array}{l}\text { Kin Placement } \\
\text { Type }\end{array}$ & $\begin{array}{l}\text { Placement } \\
\text { Timing }\end{array}$ & Length of Stay & Data Collection \\
\hline Holtan 2005 & $\begin{array}{l}\text { Not } \\
\text { Reported/Unclear }\end{array}$ & $\begin{array}{l}\text { Not } \\
\text { Reported/Unclear }\end{array}$ & $\begin{array}{l}\text { (K) - Placement - } 61.2 \\
\text { months } \\
\text { (F) - Placement - } 68.4 \\
\text { months }\end{array}$ & Cross-sectional \\
\hline Iglehart 1994 & $\begin{array}{l}\text { Not } \\
\text { Reported/Unclear }\end{array}$ & $\begin{array}{l}\text { Not } \\
\text { Reported/Unclear }\end{array}$ & & Cross-sectional \\
\hline Iglehart 1995 & $\begin{array}{l}\text { Not } \\
\text { Reported/Unclear }\end{array}$ & $\begin{array}{l}\text { Not } \\
\text { Reported/Unclear }\end{array}$ & & Cross-sectional \\
\hline Jenkins 2002 & Licensed & $\begin{array}{l}\text { Not } \\
\text { Reported/Unclear }\end{array}$ & $\begin{array}{l}\text { (K) - Placement - } 31.6 \\
\text { months } \\
(\mathrm{F}) \text { - Placement - } 19.3 \\
\text { months }\end{array}$ & Cross-sectional \\
\hline $\begin{array}{l}\text { Jones-Karena } \\
1998\end{array}$ & $\begin{array}{l}\text { Not } \\
\text { Reported/Unclear }\end{array}$ & $\begin{array}{l}\text { Not } \\
\text { Reported/Unclear }\end{array}$ & & Cross-sectional \\
\hline $\begin{array}{l}\text { Jonson-Reid } \\
2003\end{array}$ & $\begin{array}{l}\text { Not } \\
\text { Reported/Unclear }\end{array}$ & Last & & $\begin{array}{l}\text { Longitudinal - } \\
4.5 \text { years }\end{array}$ \\
\hline $\begin{array}{l}\text { Landsverk } \\
1996\end{array}$ & $\begin{array}{l}\text { Not } \\
\text { Reported/Unclear }\end{array}$ & $\begin{array}{l}\text { Not } \\
\text { Reported/Unclear }\end{array}$ & & Cross-sectional \\
\hline Leslie 2000a & $\begin{array}{l}\text { Not } \\
\text { Reported/Unclear }\end{array}$ & $\begin{array}{l}\text { Not } \\
\text { Reported/Unclear }\end{array}$ & & $\begin{array}{l}\text { Longitudinal - } \\
1.5 \text { years }\end{array}$ \\
\hline Mclntosh 2002 & $\begin{array}{l}\text { Not } \\
\text { Reported/Unclear }\end{array}$ & $\begin{array}{l}\text { Not } \\
\text { Reported/Unclear }\end{array}$ & & Cross-sectional \\
\hline McMillen 2004 & $\begin{array}{l}\text { Not } \\
\text { Reported/Unclear }\end{array}$ & $\begin{array}{l}\text { Not } \\
\text { Reported/Unclear }\end{array}$ & & Cross-sectional \\
\hline McMillen 2005 & $\begin{array}{l}\text { Not } \\
\text { Reported/Unclear }\end{array}$ & $\begin{array}{l}\text { Not } \\
\text { Reported/Unclear }\end{array}$ & & Cross-sectional \\
\hline Metzger 1997 & Unlicensed & $\begin{array}{l}\text { Not } \\
\text { Reported/Unclear }\end{array}$ & $\begin{array}{l}\text { (K) - Placement - } 74.0 \\
\text { months } \\
\text { (F) - Placement - } 77.8 \\
\text { months }\end{array}$ & Cross-sectional \\
\hline Mosek 2001 & $\begin{array}{l}\text { Not } \\
\text { Reported/Unclear }\end{array}$ & $\begin{array}{l}\text { Not } \\
\text { Reported/Unclear }\end{array}$ & $\begin{array}{l}(\mathrm{K}) \text { - OOH - } 104.4 \\
\text { months } \\
(\mathrm{F}) \text { - OOH - } 126.0 \\
\text { months }\end{array}$ & Cross-sectional \\
\hline $\begin{array}{l}\text { Rudenberg } \\
1991\end{array}$ & $\begin{array}{l}\text { Not } \\
\text { Reported/Unclear }\end{array}$ & $\begin{array}{l}\text { Not } \\
\text { Reported/Unclear }\end{array}$ & & Cross-sectional \\
\hline Sallnas 2004 & $\begin{array}{l}\text { Not } \\
\text { Reported/Unclear }\end{array}$ & First & & $\begin{array}{l}\text { Longitudinal - } 5 \\
\text { years }\end{array}$ \\
\hline $\begin{array}{l}\text { Scannapieco } \\
1997\end{array}$ & Licensed & $\begin{array}{l}\text { Not } \\
\text { Reported/Unclear }\end{array}$ & $\begin{array}{l}\text { (K) - OOH - } 33.6 \text { months } \\
\text { (F) - OOH - } 17.8 \text { months }\end{array}$ & Cross-sectional \\
\hline Shin 2003 & $\begin{array}{l}\text { Not } \\
\text { Reported/Unclear }\end{array}$ & $\begin{array}{l}\text { Not } \\
\text { Reported/Unclear }\end{array}$ & $\begin{array}{l}\text { (K) - OOH - } 96.0 \text { months } \\
\text { (F) - OOH - } 96.0 \text { months }\end{array}$ & Cross-sectional \\
\hline Sivright 2004 & $\begin{array}{l}\text { Not } \\
\text { Reported/Unclear }\end{array}$ & First & $\begin{array}{l}\text { (K) - } \mathrm{OOH}-47.3 \text { months } \\
\text { (F) - OOH - } 43.8 \text { months }\end{array}$ & Cross-sectional \\
\hline
\end{tabular}




\begin{tabular}{|c|c|c|c|c|}
\hline Study & $\begin{array}{l}\text { Kin Placement } \\
\text { Type }\end{array}$ & $\begin{array}{l}\text { Placement } \\
\text { Timing }\end{array}$ & Length of Stay & Data Collection \\
\hline Smith 2002 & Unlicensed & First & $\begin{array}{l}\text { (K) - Placement - } 13.4 \\
\text { months } \\
\text { (F) - Placement - } 5.5 \\
\text { months }\end{array}$ & $\begin{array}{l}\text { Longitudinal - } 2- \\
3 \text { years }\end{array}$ \\
\hline Smith 2003 & $\begin{array}{l}\text { Not } \\
\text { Reported/Unclear }\end{array}$ & Last & & $\begin{array}{l}\text { Longitudinal - } 11 \\
\text { months }\end{array}$ \\
\hline Sripathy 2004 & Licensed & $\begin{array}{l}\text { Not } \\
\text { Reported/Unclear }\end{array}$ & & Cross-sectional \\
\hline Strijker 2003 & $\begin{array}{l}\text { Not } \\
\text { Reported/Unclear }\end{array}$ & $\begin{array}{l}\text { Not } \\
\text { Reported/Unclear }\end{array}$ & & Cross-sectional \\
\hline Surbeck 2000 & $\begin{array}{l}\text { Not } \\
\text { Reported/Unclear }\end{array}$ & $\begin{array}{l}\text { Not } \\
\text { Reported/Unclear }\end{array}$ & $\begin{array}{l}(\mathrm{K}) \text { - Placement - } 22.9 \\
\text { months } \\
(\mathrm{F}) \text { - Placement - } 27.0 \\
\text { months }\end{array}$ & Cross-sectional \\
\hline $\begin{array}{l}\text { Tarren- } \\
\text { Sweeney } 2006\end{array}$ & $\begin{array}{l}\text { Not } \\
\text { Reported/Unclear }\end{array}$ & $\begin{array}{l}\text { Not } \\
\text { Reported/Unclear }\end{array}$ & & Cross-sectional \\
\hline Testa 1999 & $\begin{array}{l}\text { Not } \\
\text { Reported/Unclear }\end{array}$ & $\begin{array}{l}\text { Not } \\
\text { Reported/Unclear }\end{array}$ & & $\begin{array}{l}\text { Longitudinal - } 1 \text { - } \\
3 \text { years }\end{array}$ \\
\hline Testa 2001 & $\begin{array}{l}\text { Not } \\
\text { Reported/Unclear }\end{array}$ & $\begin{array}{l}\text { Not } \\
\text { Reported/Unclear }\end{array}$ & $\begin{array}{l}\text { (K) - OOH - } 63.1 \text { months } \\
(\mathrm{F})-\mathrm{OOH}-52.8 \text { months }\end{array}$ & $\begin{array}{l}\text { Longitudinal - up } \\
\text { to } 8 \text { years }\end{array}$ \\
\hline Timmer 2004 & $\begin{array}{l}\text { Not } \\
\text { Reported/Unclear }\end{array}$ & $\begin{array}{l}\text { Not } \\
\text { Reported/Unclear }\end{array}$ & & Cross-sectional \\
\hline $\begin{array}{l}\text { Tompkins Jr. } \\
2003\end{array}$ & $\begin{array}{l}\text { Licensed and } \\
\text { Unlicensed }\end{array}$ & $\begin{array}{l}\text { Not } \\
\text { Reported/Unclear }\end{array}$ & $\begin{array}{l}(\mathrm{K}) \text { - } \mathrm{OOH}-31.3 \text { months } \\
(\mathrm{F})-\mathrm{OOH}-31.0 \text { months }\end{array}$ & Cross-sectional \\
\hline Vogel 1999 & $\begin{array}{l}\text { Not } \\
\text { Reported/Unclear }\end{array}$ & First & $\begin{array}{l}(\mathrm{K})-\mathrm{OOH}-18.8 \text { months } \\
(\mathrm{F})-\mathrm{OOH}-13.8 \text { months }\end{array}$ & $\begin{array}{l}\text { Longitudinal - up } \\
\text { to } 2 \text { years }\end{array}$ \\
\hline Wells 1999 & $\begin{array}{l}\text { Not } \\
\text { Reported/Unclear }\end{array}$ & $\begin{array}{l}\text { First } \\
\text { (Reunification) } \\
\text { Last (re-entry) }\end{array}$ & & $\begin{array}{l}\text { Longitudinal - } 3 \\
\text { years }\end{array}$ \\
\hline Wilson 1999 & $\begin{array}{l}\text { Not } \\
\text { Reported/Unclear }\end{array}$ & $\begin{array}{l}\text { Not } \\
\text { Reported/Unclear }\end{array}$ & & Cross-sectional \\
\hline Zima 2000 & $\begin{array}{l}\text { Not } \\
\text { Reported/Unclear }\end{array}$ & $\begin{array}{l}\text { Not } \\
\text { Reported/Unclear }\end{array}$ & & Cross-sectional \\
\hline $\begin{array}{l}\text { Zimmerman } \\
1998\end{array}$ & $\begin{array}{l}\text { Not } \\
\text { Reported/Unclear }\end{array}$ & First & & Cross-sectional \\
\hline Zuravin 1999 & Licensed & $\begin{array}{l}\text { Not } \\
\text { Reported/Unclear }\end{array}$ & & $\begin{array}{l}\text { Longitudinal - } 5 \\
\text { years }\end{array}$ \\
\hline
\end{tabular}




\subsection{OUTCOME MEASURES}

\begin{tabular}{|c|c|c|c|c|c|c|c|c|}
\hline Study & $\begin{array}{l}\text { Behavioral } \\
\text { Development }\end{array}$ & Mental Health & $\begin{array}{l}\text { Placement } \\
\text { Stability }\end{array}$ & Permanency & $\begin{array}{l}\text { Educational } \\
\text { Attainment }\end{array}$ & Family Relations & Service Utilization & Re-abuse \\
\hline Barth 1994 & & & & $\begin{array}{l}\text { Outcome } \\
\text { categories: } \\
\text { Adoption, Still in } \\
\text { Placement } \\
\text { Measured using } \\
\text { administrative } \\
\text { database }\end{array}$ & & & & \\
\hline $\begin{array}{l}\text { Belanger } \\
2002\end{array}$ & $\begin{array}{l}\text { Outcome category: } \\
\text { Adaptive Behaviors } \\
\text { (Continuous) } \\
\text { Measured using } \\
\text { caregiver report and } \\
\text { standardized } \\
\text { instrumention - } \\
\text { Vineland Aadptive } \\
\text { Behavior Scales: } \\
\text { Interview Edition } \\
\text { Survey Form }\end{array}$ & $\begin{array}{l}\text { Outcome category: } \\
\text { Psychiatric } \\
\text { Disorders } \\
\text { (Continuous) } \\
\text { Measured using } \\
\text { caregiver report } \\
\text { and standardized } \\
\text { instrumention - } \\
\text { Devereaux Scales } \\
\text { of mental Disorders } \\
\text { (DSMD) }\end{array}$ & $\begin{array}{l}\text { Outcome } \\
\text { categories: } \\
\text { Number of } \\
\text { Placements } \\
\text { (Continuous), } \\
\text { Length of Stay } \\
\text { (OOH Care) } \\
\text { Measured using } \\
\text { caregiver report }\end{array}$ & & & & & \\
\hline
\end{tabular}




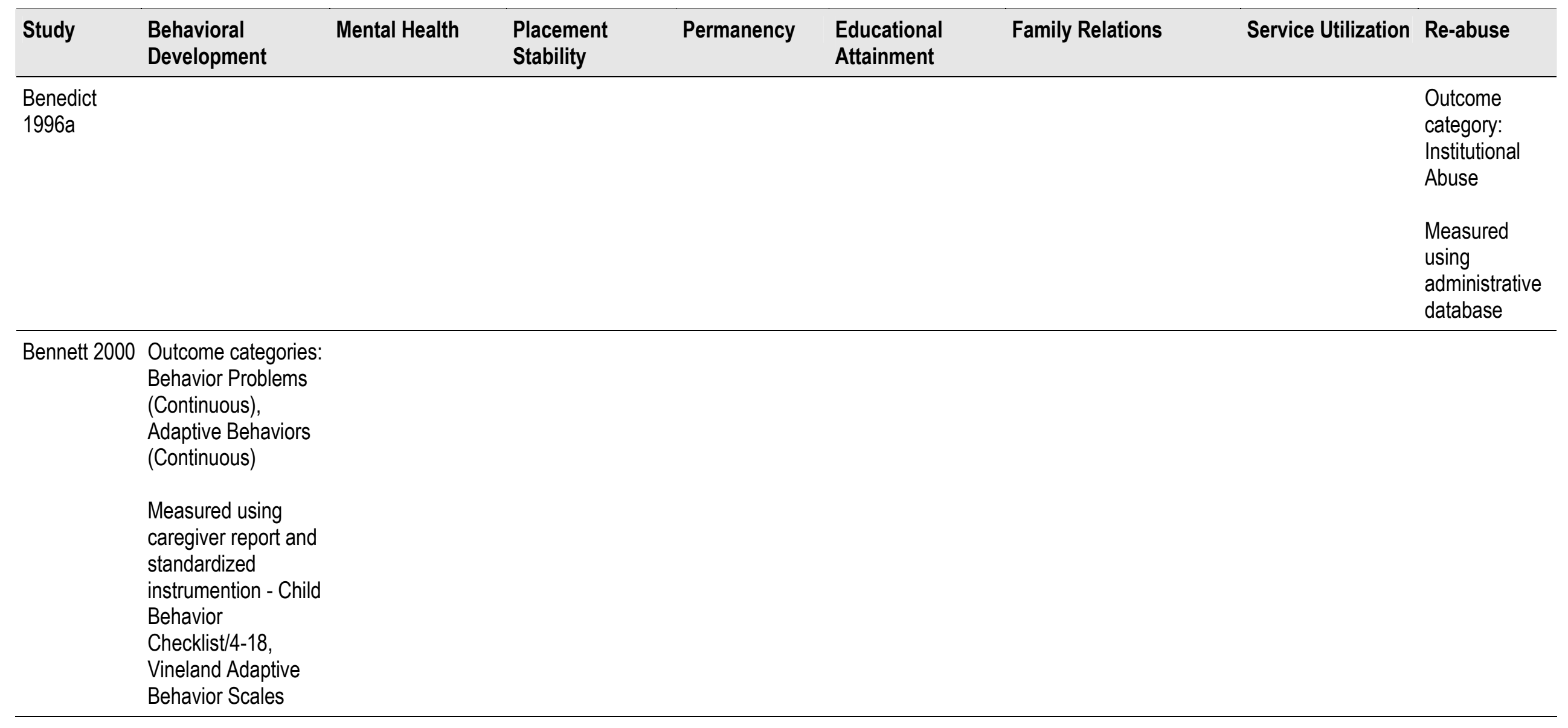




\begin{tabular}{|c|c|c|c|c|c|c|c|}
\hline Study & $\begin{array}{l}\text { Behavioral } \\
\text { Development }\end{array}$ & Mental Health & $\begin{array}{l}\text { Placement } \\
\text { Stability }\end{array}$ & Permanency & $\begin{array}{l}\text { Educational } \\
\text { Attainment }\end{array}$ & Family Relations & Service Utilization Re-abuse \\
\hline Berrick 1997 & & & & & & $\begin{array}{l}\text { Outcome category: } \\
\text { Conflict (Continuous) } \\
\text { Measured using caregiver } \\
\text { report and standardized } \\
\text { instrumention - Index of } \\
\text { Family Relations }\end{array}$ & \\
\hline Berrick 1999 & & & $\begin{array}{l}\text { Outcome } \\
\text { category: re-entry } \\
\text { Measured using } \\
\text { adminstrative } \\
\text { database }\end{array}$ & $\begin{array}{l}\text { Outcome } \\
\text { categories: } \\
\text { Reunification, } \\
\text { Adoption, } \\
\text { Guardianship, } \\
\text { Still in } \\
\text { Placement } \\
\text { Measured using } \\
\text { adminstrative } \\
\text { database }\end{array}$ & & & \\
\hline $\begin{array}{l}\text { Berrick, Oth } \\
1994\end{array}$ & & & $\begin{array}{l}\text { Outcome } \\
\text { category: Length } \\
\text { of Stay } \\
\text { (Placement) } \\
\text { Measured using } \\
\text { caregiver report }\end{array}$ & & $\begin{array}{l}\text { Outcome category: } \\
\text { Repeated a Grade } \\
\text { Measured using } \\
\text { caregiver report }\end{array}$ & & $\begin{array}{l}\text { Outcome category: } \\
\text { Mental Health } \\
\text { Services } \\
\text { Measured using } \\
\text { caregiver report }\end{array}$ \\
\hline
\end{tabular}




\begin{tabular}{|c|c|c|c|c|c|c|c|}
\hline Study & $\begin{array}{l}\text { Behavioral } \\
\text { Development }\end{array}$ & Mental Health & $\begin{array}{l}\text { Placement } \\
\text { Stability }\end{array}$ & Permanency & $\begin{array}{l}\text { Educational } \\
\text { Attainment }\end{array}$ & Family Relations & Service Utilization Re-abuse \\
\hline Bilaver 1999 & & $\begin{array}{l}\text { Outcome category: } \\
\text { Psychiatric } \\
\text { Disorders } \\
\text { (Continuous) } \\
\text { Measured using } \\
\text { administrative } \\
\text { database }\end{array}$ & & & & & $\begin{array}{l}\text { Outcome } \\
\text { categories: Mental } \\
\text { Health Services, } \\
\text { Physician Services, } \\
\text { Developmental } \\
\text { Services } \\
\text { Measured using } \\
\text { administrative } \\
\text { database }\end{array}$ \\
\hline Brooks 1998 & $\begin{array}{l}\text { Outcome categories: } \\
\text { Behavior Problems } \\
\text { (Continuous), } \\
\text { Adaptive Behaviors } \\
\text { (Continuous) } \\
\text { Measured using } \\
\text { caregiver report and } \\
\text { standardized } \\
\text { instrumention - } \\
\text { Behavior Problem } \\
\text { Index (BPI), Grow- } \\
\text { Up Scale }\end{array}$ & & $\begin{array}{l}\text { Outcome } \\
\text { category: Length } \\
\text { of Stay } \\
\text { (Placement) } \\
\text { Measured using } \\
\text { caregiver report }\end{array}$ & & $\begin{array}{l}\text { Outcome category: } \\
\text { Repeated a Grade } \\
\text { Measured using } \\
\text { caregiver report }\end{array}$ & & \\
\hline
\end{tabular}




\begin{tabular}{|c|c|c|c|c|c|c|c|}
\hline Study & $\begin{array}{l}\text { Behavioral } \\
\text { Development }\end{array}$ & Mental Health & $\begin{array}{l}\text { Placement } \\
\text { Stability }\end{array}$ & Permanency & $\begin{array}{l}\text { Educational } \\
\text { Attainment }\end{array}$ & Family Relations & Service Utilization Re-abuse \\
\hline $\begin{array}{l}\text { Chamberlain } \\
2006\end{array}$ & & & $\begin{array}{l}\text { Outcome } \\
\text { category: } \\
\text { Placement } \\
\text { Disruption } \\
\text { Measured using } \\
\text { caregiver report }\end{array}$ & & & & \\
\hline $\begin{array}{l}\text { Chapman } \\
2004\end{array}$ & & & & & & $\begin{array}{l}\text { Outcome category: } \\
\text { Attachment (Continuous) } \\
\text { Measured using self- } \\
\text { report }\end{array}$ & \\
\hline Chew 1998 & & & & & & $\begin{array}{l}\text { Outcome category: } \\
\text { Attachment (Continuous) } \\
\text { Measured using } \\
\text { standardized } \\
\text { instrumention - } \\
\text { Attachment Q-Sort } \\
\text { Version } 3 \text { - and } \\
\text { researcher observation }\end{array}$ & \\
\hline $\begin{array}{l}\text { Christopher } \\
1998\end{array}$ & & & & & $\begin{array}{l}\text { Outcome category: } \\
\text { Educational } \\
\text { Attainment } \\
\text { Measured using } \\
\text { case records }\end{array}$ & & \\
\hline
\end{tabular}




\begin{tabular}{|c|c|c|c|c|c|c|c|}
\hline Study & $\begin{array}{l}\text { Behavioral } \\
\text { Development }\end{array}$ & Mental Health & $\begin{array}{l}\text { Placement } \\
\text { Stability }\end{array}$ & Permanency & $\begin{array}{l}\text { Educational } \\
\text { Attainment }\end{array}$ & Family Relations & Service Utilization Re-abuse \\
\hline Clyman 1998 & & & $\begin{array}{l}\text { Outcome } \\
\text { category: Length } \\
\text { of Stay }(\mathrm{OOH} \\
\text { Care) } \\
\text { Measured using } \\
\text { caregiver report }\end{array}$ & & & & $\begin{array}{l}\text { Outcome } \\
\text { categories: Mental } \\
\text { Health Services, } \\
\text { Physician Services, } \\
\text { Developmental } \\
\text { Services } \\
\text { Measured using } \\
\text { caregiver report } \\
\text { and standardized } \\
\text { instrumention - The } \\
\text { Young Kids Early } \\
\text { Services } \\
\text { Assessments } 1.0 \\
\text { (TYKES) }\end{array}$ \\
\hline Cole 2006 & & & $\begin{array}{l}\text { Outcome } \\
\text { category: Length } \\
\text { of Stay } \\
\text { (Placement) } \\
\text { Measured using } \\
\text { caregiver report } \\
\text { and standardized } \\
\text { instrumention - } \\
\text { Caregiver } \\
\text { Interview Form } \\
\text { (CIF) }\end{array}$ & & & $\begin{array}{l}\text { Outcome category: } \\
\text { Attachment } \\
\text { (Dichotomous) } \\
\text { Measured using } \\
\text { standardized } \\
\text { instrumention - Ainsworth } \\
\text { Strange Situation } \\
\text { Procedure (ASSP) - and } \\
\text { observational methods }\end{array}$ & \\
\hline
\end{tabular}




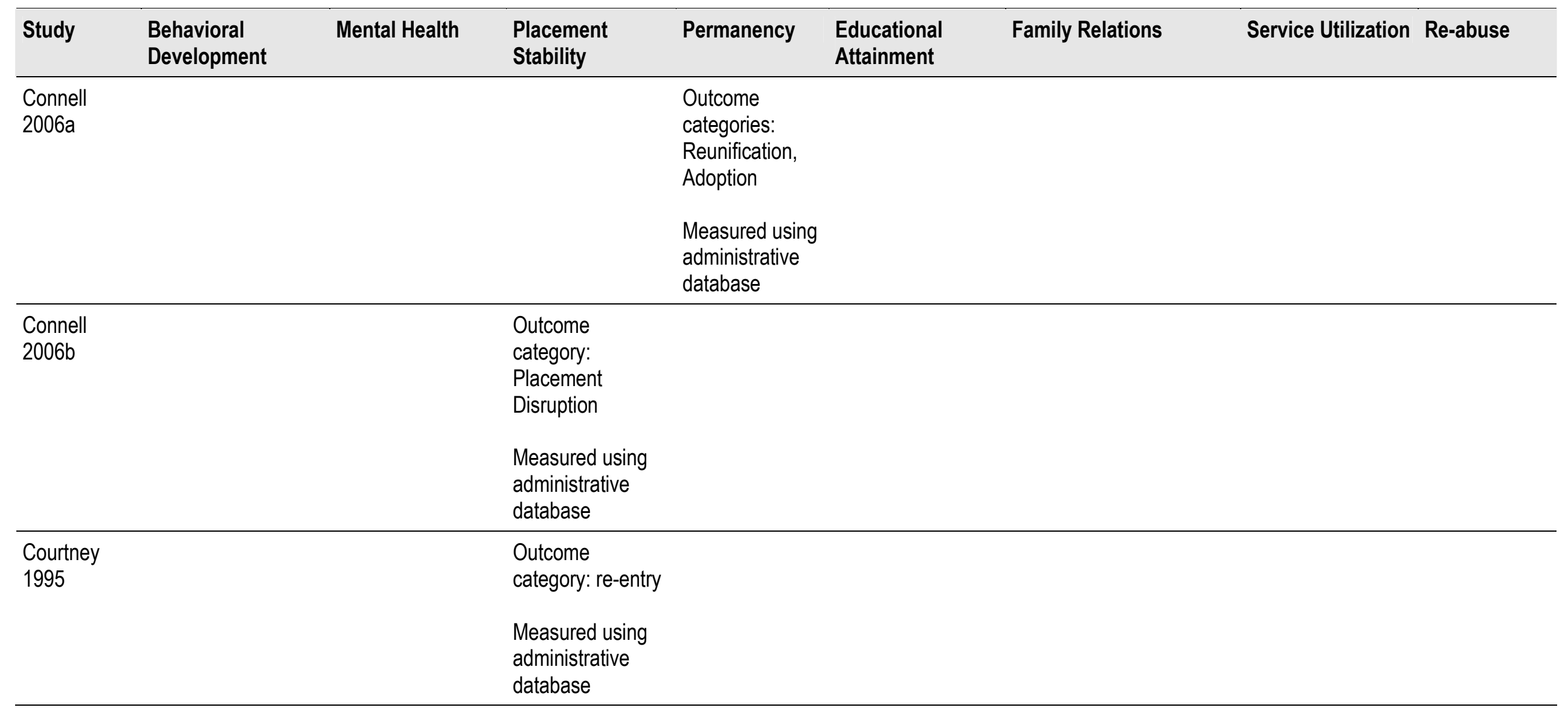




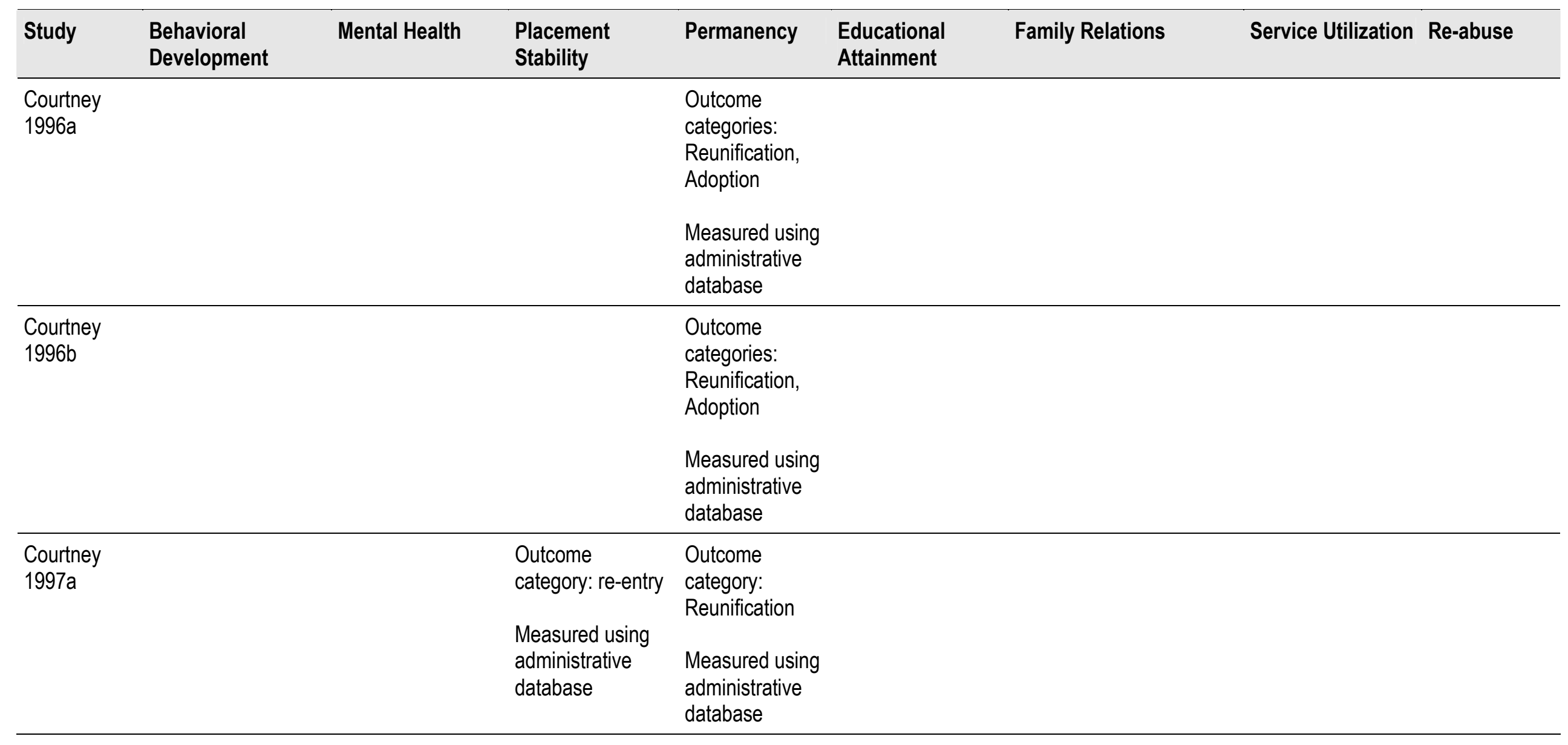




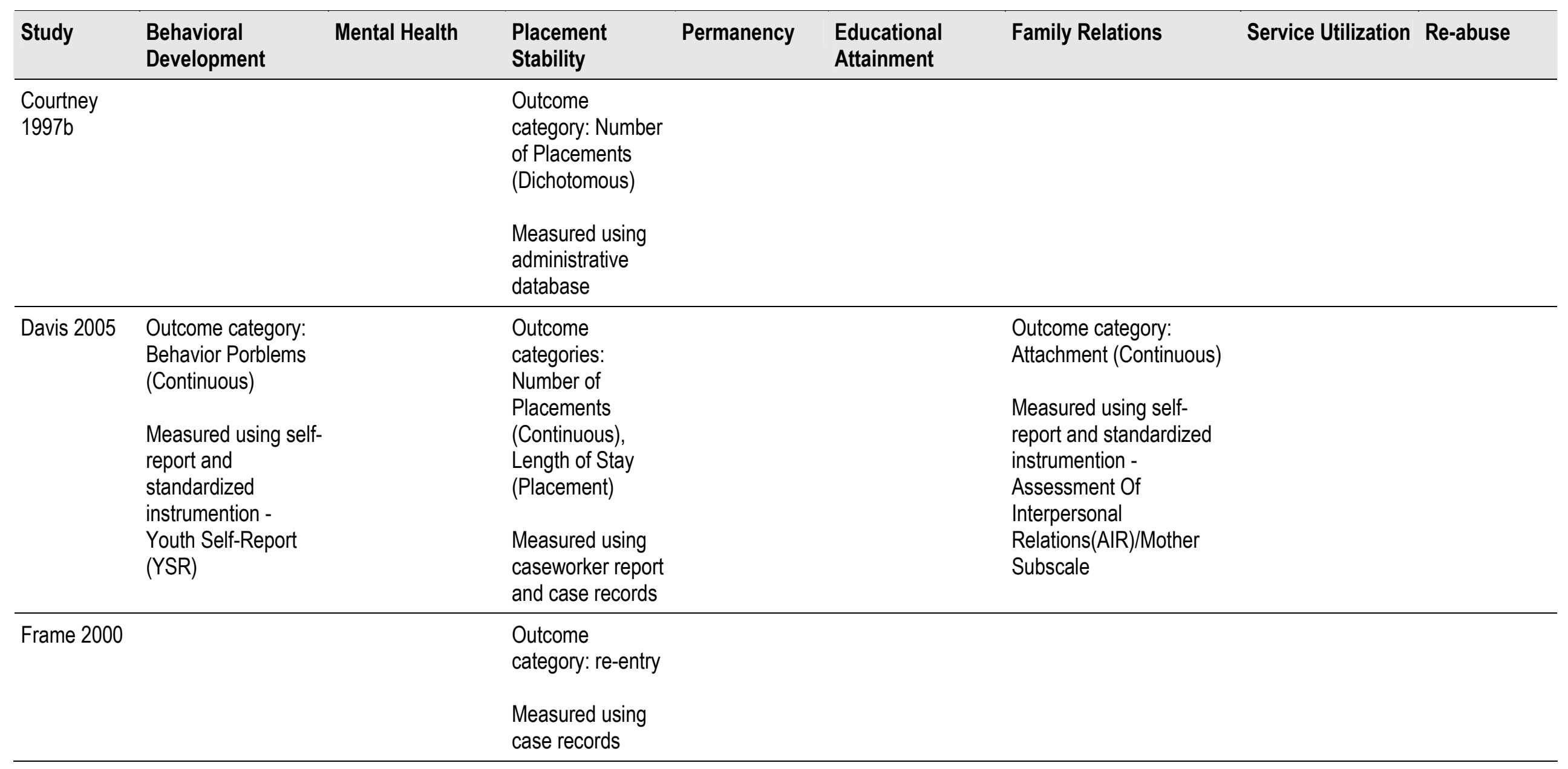




\begin{tabular}{|c|c|c|c|c|c|c|c|c|}
\hline Study & $\begin{array}{l}\text { Behavioral } \\
\text { Development }\end{array}$ & Mental Health & $\begin{array}{l}\text { Placement } \\
\text { Stability }\end{array}$ & Permanency & $\begin{array}{l}\text { Educational } \\
\text { Attainment }\end{array}$ & Family Relations & Service Utilization & Re-abuse \\
\hline Frame 2002 & & & $\begin{array}{l}\text { Outcome } \\
\text { category: re-entry } \\
\text { Measured using } \\
\text { adminstrative } \\
\text { database and } \\
\text { caseworker report }\end{array}$ & $\begin{array}{l}\text { Outcome } \\
\text { categories: } \\
\text { Reunification, } \\
\text { Still in } \\
\text { Placement } \\
\text { Measured using } \\
\text { adminstrative } \\
\text { database and } \\
\text { caseworker } \\
\text { report }\end{array}$ & & & & \\
\hline Fuller 2005 & & & & & & & & $\begin{array}{l}\text { Outcome } \\
\text { category: } \\
\text { Recurrence of } \\
\text { Abuse } \\
\text { Measured } \\
\text { using } \\
\text { administrative } \\
\text { database }\end{array}$ \\
\hline $\begin{array}{l}\text { Grogan- } \\
\text { Kaylor } 2000\end{array}$ & & & & $\begin{array}{l}\text { Outcome } \\
\text { category: } \\
\text { Reunification } \\
\text { Measured using } \\
\text { administrative } \\
\text { database }\end{array}$ & & & & \\
\hline
\end{tabular}




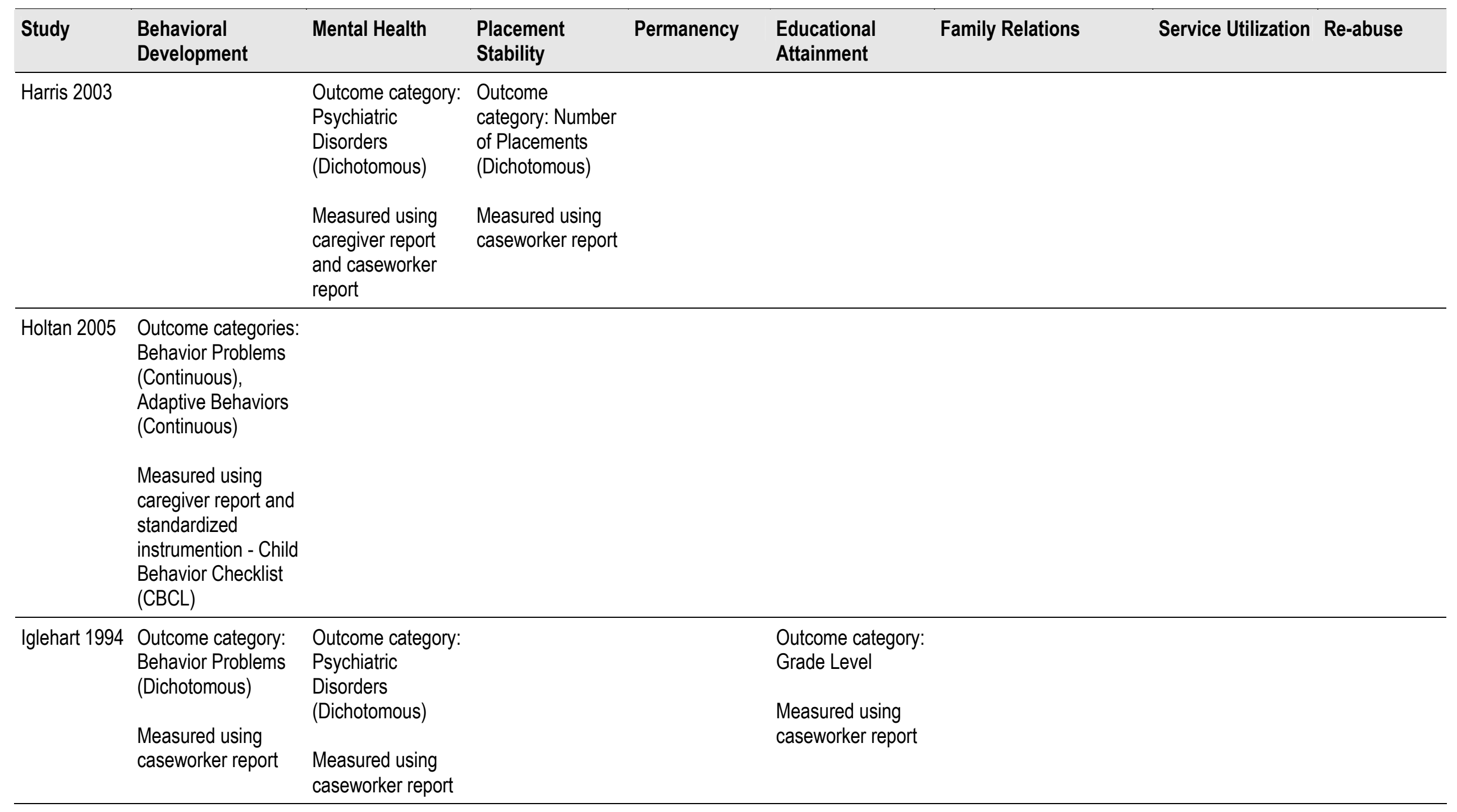




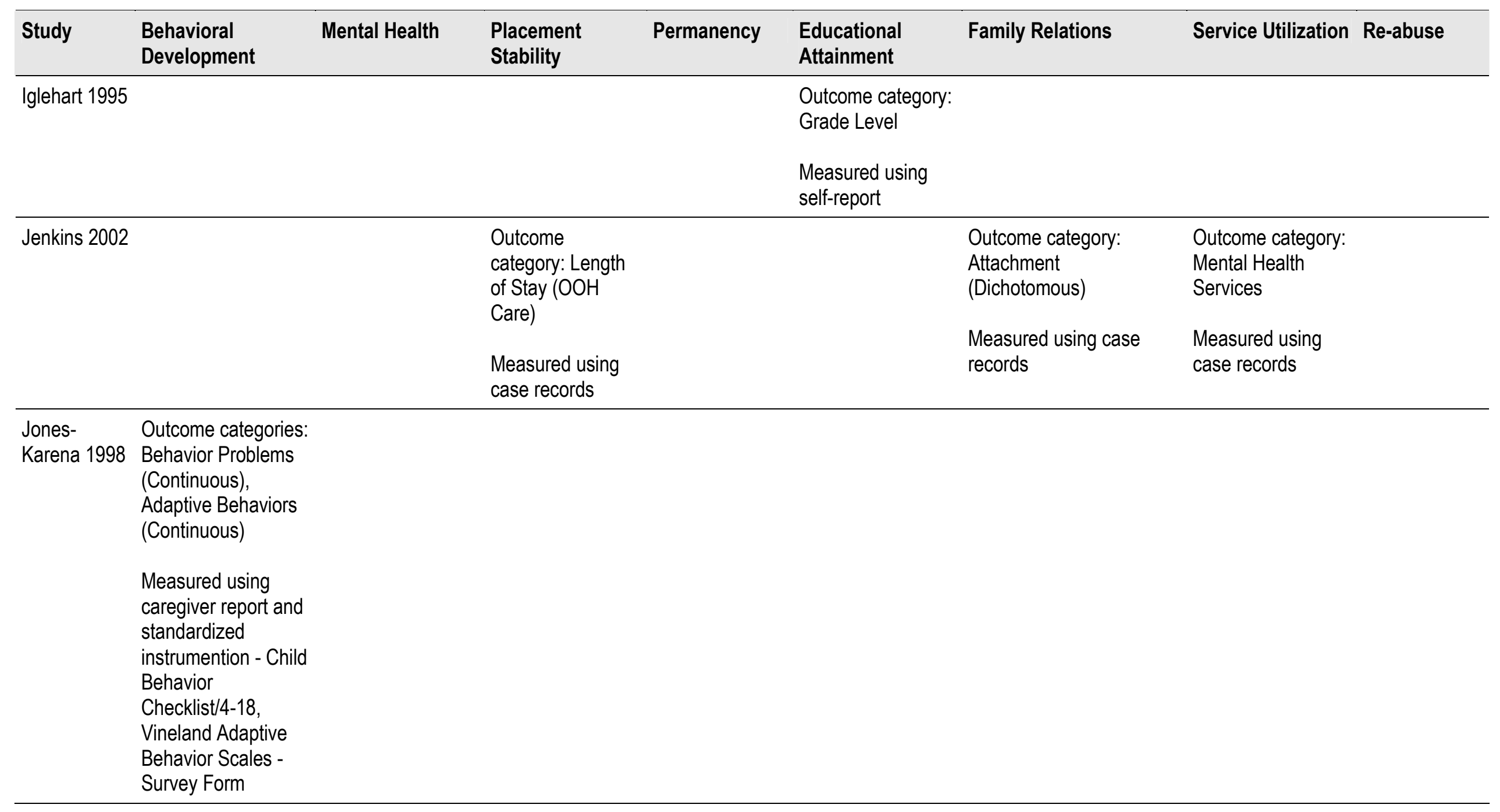




\begin{tabular}{|c|c|c|c|c|c|c|c|c|}
\hline Study & $\begin{array}{l}\text { Behavioral } \\
\text { Development }\end{array}$ & Mental Health & $\begin{array}{l}\text { Placement } \\
\text { Stability }\end{array}$ & Permanency & $\begin{array}{l}\text { Educational } \\
\text { Attainment }\end{array}$ & Family Relations & Service Utilization & Re-abuse \\
\hline $\begin{array}{l}\text { Jonson-Reid } \\
2003\end{array}$ & & & $\begin{array}{l}\text { Outcome } \\
\text { category: re-entry } \\
\text { Measured using } \\
\text { administrative } \\
\text { database }\end{array}$ & & & & & $\begin{array}{l}\text { Outcome } \\
\text { category: } \\
\text { Recurrence of } \\
\text { Abuse } \\
\text { Measured } \\
\text { using } \\
\text { administrative } \\
\text { database }\end{array}$ \\
\hline $\begin{array}{l}\text { Landsverk } \\
1996\end{array}$ & $\begin{array}{l}\text { Outcome category: } \\
\text { Behavior Problems } \\
\text { (Continuous) } \\
\text { Measured using } \\
\text { caregiver report and } \\
\text { standardized } \\
\text { instrumention - Child } \\
\text { Behavior Checklist } \\
\text { (CBCL) }\end{array}$ & & & & & & & \\
\hline Leslie 2000a & & & & & & & $\begin{array}{l}\text { Outcome category: } \\
\text { Mental Health } \\
\text { Services } \\
\text { Measured using } \\
\text { administrative } \\
\text { database and case } \\
\text { records }\end{array}$ & \\
\hline
\end{tabular}




\begin{tabular}{|c|c|c|c|c|c|c|c|}
\hline Study & $\begin{array}{l}\text { Behavioral } \\
\text { Development }\end{array}$ & Mental Health & $\begin{array}{l}\text { Placement } \\
\text { Stability }\end{array}$ & Permanency & $\begin{array}{l}\text { Educational } \\
\text { Attainment }\end{array}$ & Family Relations & Service Utilization Re-abuse \\
\hline $\begin{array}{l}\text { Mclntosh } \\
2002\end{array}$ & & & & $\begin{array}{l}\text { Outcome } \\
\text { category: } \\
\text { Reunification } \\
\text { Measured using } \\
\text { administrative } \\
\text { database }\end{array}$ & & & \\
\hline $\begin{array}{l}\text { McMillen } \\
2004\end{array}$ & & & & & & & $\begin{array}{l}\text { Outcome category: } \\
\text { Mental Health } \\
\text { Services } \\
\text { Measured using } \\
\text { self-report }\end{array}$ \\
\hline $\begin{array}{l}\text { McMillen } \\
2005\end{array}$ & & $\begin{array}{l}\text { Outcome category: } \\
\text { Psychiatric } \\
\text { Disorders } \\
\text { (Dichotomous) } \\
\text { Measured using } \\
\text { self-report and } \\
\text { standardized } \\
\text { instrumentation - } \\
\text { DSM-IV }\end{array}$ & & & & & \\
\hline
\end{tabular}




\begin{tabular}{|c|c|c|c|c|c|c|c|}
\hline Study & $\begin{array}{l}\text { Behavioral } \\
\text { Development }\end{array}$ & Mental Health & $\begin{array}{l}\text { Placement } \\
\text { Stability }\end{array}$ & Permanency & $\begin{array}{l}\text { Educational } \\
\text { Attainment }\end{array}$ & Family Relations & Service Utilization Re-abuse \\
\hline $\begin{array}{l}\text { Metzger } \\
1997\end{array}$ & $\begin{array}{l}\text { Outcome category: } \\
\text { Behavioral Problems } \\
\text { (Continuous) } \\
\text { Measured using } \\
\text { caseworker report } \\
\text { and standardized } \\
\text { instrumentation - } \\
\text { The Festinger } \\
\text { Scales/Rating of } \\
\text { Behavioral } \\
\text { Reactions }\end{array}$ & $\begin{array}{l}\text { Outcome category: } \\
\text { Well-Being } \\
\text { (Continuous) } \\
\text { Measured using } \\
\text { self-report and } \\
\text { standardized } \\
\text { instrumentation - } \\
\text { Personal Attribute } \\
\text { Inventory for } \\
\text { Children }\end{array}$ & $\begin{array}{l}\text { Outcome } \\
\text { categories: } \\
\text { Number of } \\
\text { Placements } \\
\text { (Dichotomous), } \\
\text { Length of Stay } \\
\text { (Placement) } \\
\text { Measured using } \\
\text { caseworker report } \\
\text { and case records }\end{array}$ & & $\begin{array}{l}\text { Outcome category: } \\
\text { Repeated a Grade } \\
\text { Measured using } \\
\text { caseworker report } \\
\text { and case records }\end{array}$ & & $\begin{array}{l}\text { Outcome category: } \\
\text { Mental Health } \\
\text { Services } \\
\text { Measured using } \\
\text { caseworker report } \\
\text { and case records }\end{array}$ \\
\hline Mosek 2001 & & $\begin{array}{l}\text { Outcome category: } \\
\text { Well-Being } \\
\text { (Continuous) } \\
\text { Measured using } \\
\text { self-report and } \\
\text { standardized } \\
\text { instrumentation - } \\
\text { Offer Self-Image } \\
\text { Questionnaire } \\
\text { (OSIQ) }\end{array}$ & & & & $\begin{array}{l}\text { Outcome category: } \\
\text { Attachment } \\
\text { (Dichotomous) } \\
\text { Measured using self- } \\
\text { report }\end{array}$ & \\
\hline
\end{tabular}




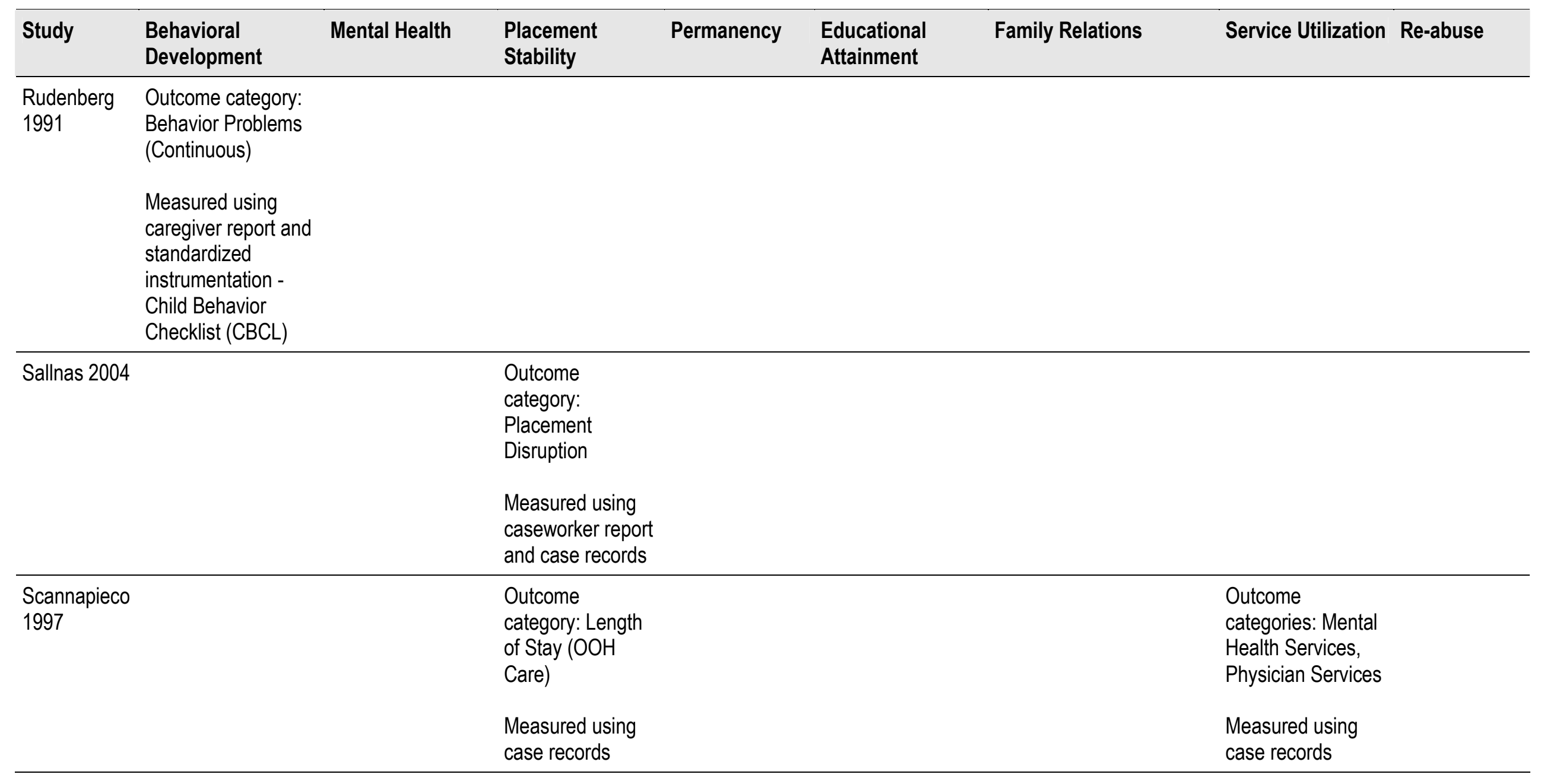




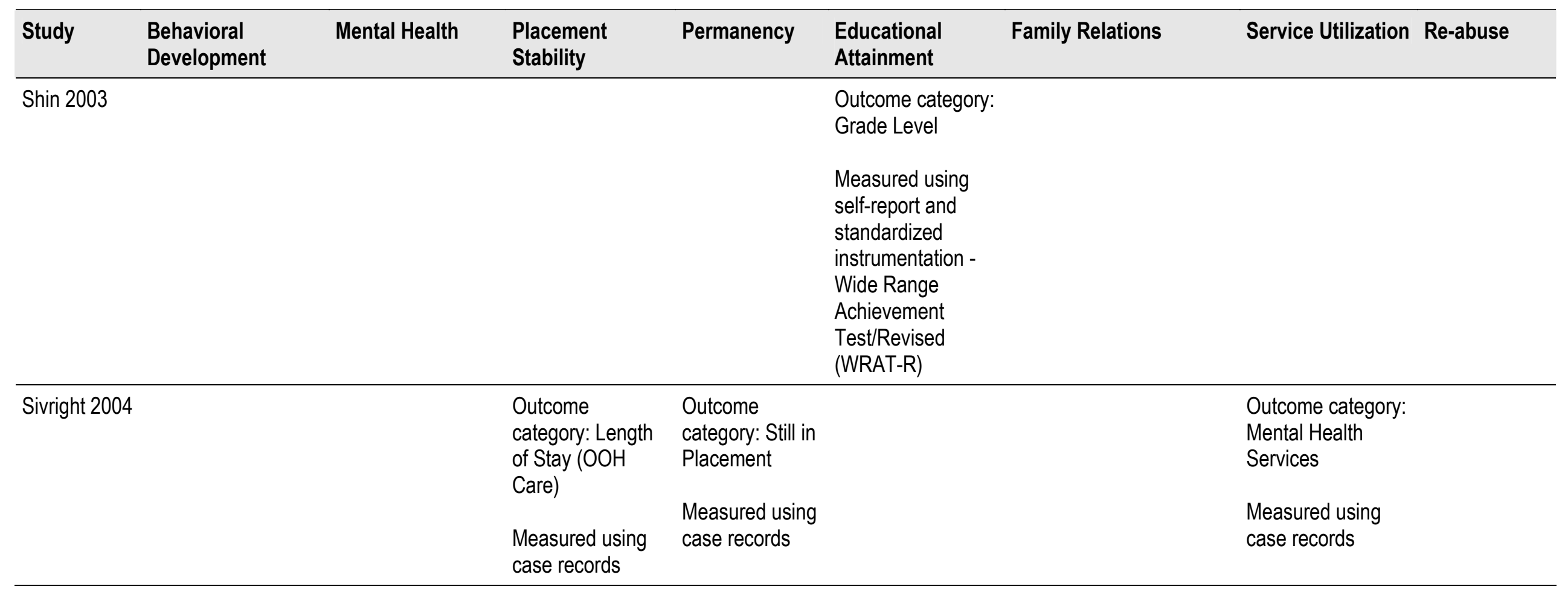




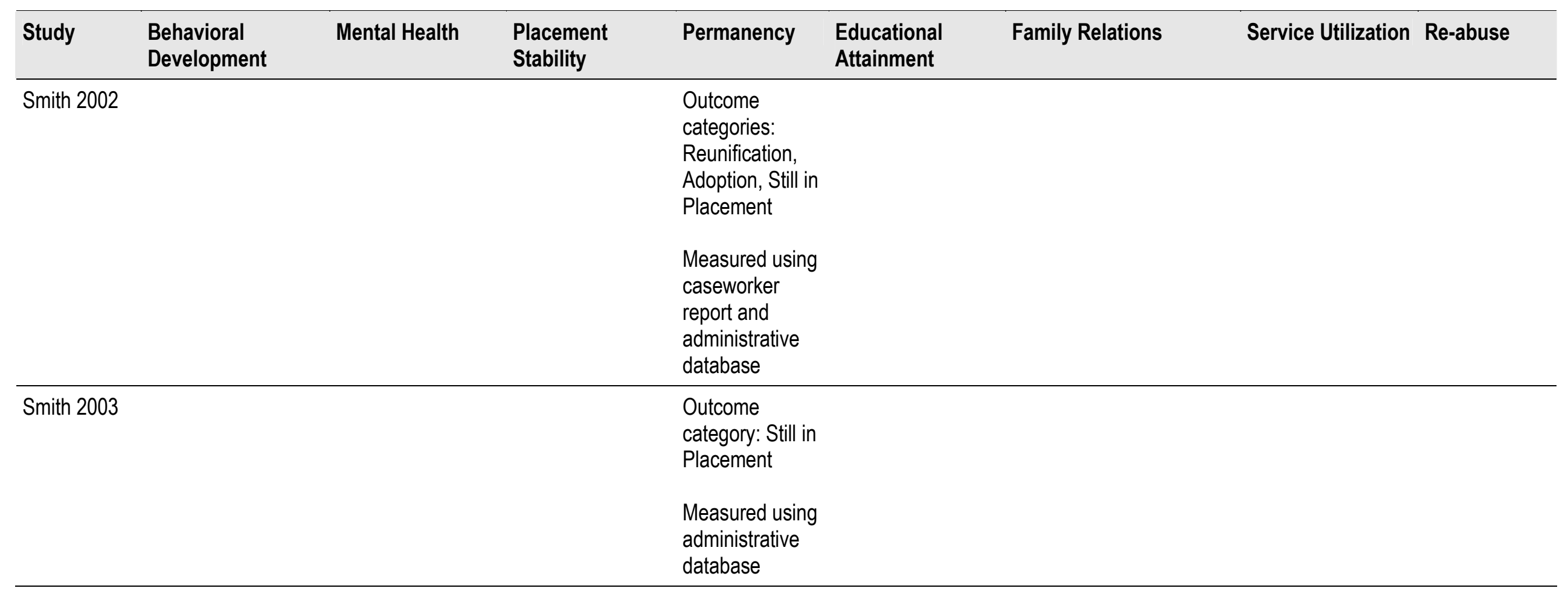




\begin{tabular}{|c|c|c|c|c|c|c|c|}
\hline Study & $\begin{array}{l}\text { Behavioral } \\
\text { Development }\end{array}$ & Mental Health & $\begin{array}{l}\text { Placement } \\
\text { Stability }\end{array}$ & Permanency & $\begin{array}{l}\text { Educational } \\
\text { Attainment }\end{array}$ & Family Relations & Service Utilization Re-abuse \\
\hline $\begin{array}{l}\text { Sripathy } \\
2004\end{array}$ & $\begin{array}{l}\text { Outcome categories: } \\
\text { Behavior Problems } \\
\text { (Continuous), } \\
\text { Adaptive Problems } \\
\text { (Continuous) } \\
\\
\text { Measured using } \\
\text { caregiver report and } \\
\text { standardized } \\
\text { instrumentation - } \\
\text { Child Behavior } \\
\text { Checklist (CBCL) }\end{array}$ & & & & $\begin{array}{l}\text { Outcome category: } \\
\text { Repeated a Grade } \\
\text { Measured using } \\
\text { caregiver report }\end{array}$ & & $\begin{array}{l}\text { Outcome category: } \\
\text { Mental Health } \\
\text { Services } \\
\text { Measured using } \\
\text { caregiver report }\end{array}$ \\
\hline Strijker 2003 & $\begin{array}{l}\text { Outcome category: } \\
\text { Behavior Problems } \\
\text { (Continuous) } \\
\text { Measured using } \\
\text { caregiver report and } \\
\text { standardized } \\
\text { instrumentation - } \\
\text { Child Behavior } \\
\text { Checklist 4-18 } \\
\text { (CBCL/4-18) }\end{array}$ & & & & & $\begin{array}{l}\text { Outcome category: } \\
\text { Attachment (Continuous) } \\
\text { Measured using caregiver } \\
\text { report and standardized } \\
\text { instrumentation - } \\
\text { Attachment Scale }\end{array}$ & \\
\hline
\end{tabular}




\begin{tabular}{|c|c|c|c|c|c|c|}
\hline Study & $\begin{array}{l}\text { Behavioral } \\
\text { Development }\end{array}$ & $\begin{array}{l}\text { Placement } \\
\text { Stability }\end{array}$ & Permanency & $\begin{array}{l}\text { Educational } \\
\text { Attainment }\end{array}$ & Family Relations & Service Utilization Re-abuse \\
\hline $\begin{array}{l}\text { Surbeck } \\
2000\end{array}$ & $\begin{array}{l}\text { Outcome categories: } \\
\text { Behavior Problems } \\
\text { (Continuous), } \\
\text { Adaptive Behaviors } \\
\text { (Continuous) } \\
\text { Measured using } \\
\text { case records }\end{array}$ & $\begin{array}{l}\text { Outcome } \\
\text { category: Length } \\
\text { of Stay } \\
\text { (Placement) } \\
\text { Measured using } \\
\text { case records }\end{array}$ & & & $\begin{array}{l}\text { Outcome category: } \\
\text { Attachment (Continuous) } \\
\text { Measured using case } \\
\text { records }\end{array}$ & \\
\hline $\begin{array}{l}\text { Tarren- } \\
\text { Sweeney } \\
2006\end{array}$ & $\begin{array}{l}\text { Outcome categories: } \\
\text { Behavior Problems } \\
\text { (Continuous), } \\
\text { Adaptive Behaviors } \\
\text { (Continuous) } \\
\text { Measured using } \\
\text { caregiver report and } \\
\text { standardized } \\
\text { instrumentation - } \\
\text { Child Behavior } \\
\text { Checklist (CBCL) }\end{array}$ & & & & & \\
\hline
\end{tabular}




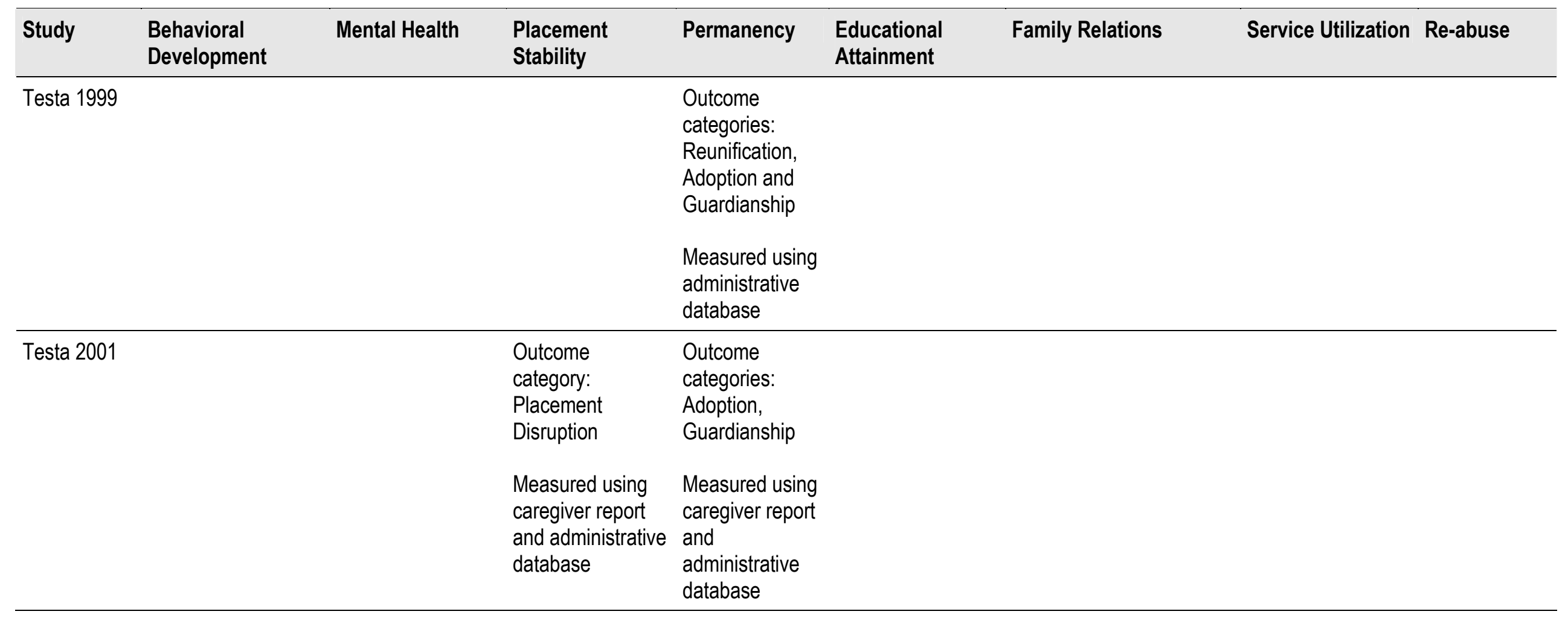




\begin{tabular}{|c|c|c|c|c|c|c|c|}
\hline Study & $\begin{array}{l}\text { Behavioral } \\
\text { Development }\end{array}$ & Mental Health & $\begin{array}{l}\text { Placement } \\
\text { Stability }\end{array}$ & Permanency & $\begin{array}{l}\text { Educational } \\
\text { Attainment }\end{array}$ & Family Relations & Service Utilization Re-abuse \\
\hline Timmer 2004 & $\begin{array}{l}\text { Outcome category: } \\
\text { Behavior Problems } \\
\text { (Continuous) } \\
\text { Measured using } \\
\text { caregiver report and } \\
\text { standardized } \\
\text { instrumentation - } \\
\text { Child Behavior } \\
\text { Checklist (CBCL) }\end{array}$ & & & & & & \\
\hline $\begin{array}{l}\text { Tompkins Jr. } \\
2003\end{array}$ & & $\begin{array}{l}\text { Outcome category: } \\
\text { Well-Being } \\
\text { (Dichotomous) } \\
\text { Measured using } \\
\text { caseworker report }\end{array}$ & $\begin{array}{l}\text { Outcome } \\
\text { category: Length } \\
\text { of Stay (OOH } \\
\text { Care) } \\
\text { Measured using } \\
\text { caseworker report }\end{array}$ & & & & $\begin{array}{l}\text { Outcome } \\
\text { categories: Mental } \\
\text { Health Services, } \\
\text { Physician Services } \\
\text { Measured using } \\
\text { caseworker report }\end{array}$ \\
\hline Vogel 1999 & & & $\begin{array}{l}\text { Outcome } \\
\text { category: Length } \\
\text { of Stay }(\mathrm{OOH} \\
\text { Care) } \\
\text { Measured using } \\
\text { administrative } \\
\text { database }\end{array}$ & & & & \\
\hline
\end{tabular}




\begin{tabular}{|c|c|c|c|c|c|c|c|}
\hline Study & $\begin{array}{l}\text { Behavioral } \\
\text { Development }\end{array}$ & Mental Health & $\begin{array}{l}\text { Placement } \\
\text { Stability }\end{array}$ & Permanency & $\begin{array}{l}\text { Educational } \\
\text { Attainment }\end{array}$ & Family Relations & Service Utilization Re-abuse \\
\hline Wells 1999 & & & $\begin{array}{l}\text { Outcome } \\
\text { category: re-entry } \\
\text { Measured using } \\
\text { administrative } \\
\text { database }\end{array}$ & $\begin{array}{l}\text { Outcome } \\
\text { category: } \\
\text { Reunification } \\
\text { Measured using } \\
\text { administrative } \\
\text { databse }\end{array}$ & & & \\
\hline Wilson 1999 & & $\begin{array}{l}\text { Outcome category: } \\
\text { Well-Being } \\
\text { (Dichotomous) } \\
\text { Measured using } \\
\text { self-report }\end{array}$ & & & & & \\
\hline Zima 2000 & $\begin{array}{l}\text { Outcome categories: } \\
\text { Behavior Problems } \\
\text { (Continuous), } \\
\text { Adaptive Behaviors } \\
\text { (Continuous) } \\
\text { Measured using } \\
\text { caregiver report and } \\
\text { standardized } \\
\text { instrumentation - } \\
\text { Child behavior } \\
\text { Checklist (CBCL) }\end{array}$ & & & & $\begin{array}{l}\text { Outcome category: } \\
\text { Repeated a Grade } \\
\text { Measured using } \\
\text { caregiver report }\end{array}$ & & \\
\hline
\end{tabular}




\begin{tabular}{|c|c|c|c|c|c|c|c|c|}
\hline Study & $\begin{array}{l}\text { Behavioral } \\
\text { Development }\end{array}$ & Mental Health & $\begin{array}{l}\text { Placement } \\
\text { Stability }\end{array}$ & Permanency & $\begin{array}{l}\text { Educational } \\
\text { Attainment }\end{array}$ & Family Relations & Service Utilization & Re-abuse \\
\hline $\begin{array}{l}\text { Zimmerman } \\
1998\end{array}$ & & & $\begin{array}{l}\text { Outcome } \\
\text { category: Number } \\
\text { of Placements } \\
\text { (Dichotomous) } \\
\text { Measured using } \\
\text { administrative } \\
\text { database and } \\
\text { case records }\end{array}$ & $\begin{array}{l}\text { Outcome } \\
\text { categories: } \\
\text { Reunification } \\
\text { Measured using } \\
\text { administrative } \\
\text { database and } \\
\text { case records }\end{array}$ & & & & \\
\hline Zuravin 1999 & & & & & & & & $\begin{array}{l}\text { Outcome } \\
\text { category: } \\
\text { Institutional } \\
\text { Abuse } \\
\text { Measured } \\
\text { using } \\
\text { administartive } \\
\text { database }\end{array}$ \\
\hline
\end{tabular}




\section{References to studies}

\subsection{INCLUDED STUDIES}

\section{BARTH 1994}

Barth RP, Courtney M, Berrick JD, Albert V. Time to adoption. In: From Child Abuse to Permanency Planning: Child Welfare Services, Pathways and Placements. New York: Aldine de Gruyter GAldine de GrAldine de Gruyter, 1994. [MEDLINE: 5970]

\section{BELANGER 2002}

Belanger SA. The advisability of kinship foster placements: A comparison of adaptive behaviors and psychopathology of children in traditional and kinship foster care [PhD]. New York: Fordham University, 2002.

\section{BENEDICT 1996A}

Benedict MI, Zuravin S, Somerfield M, Brandt D. The reported health and functioning of children maltreated while in family foster care. Child Abuse \& Neglect 1996;20(7):561-571. [MEDLINE: 5614]

\section{BENNETT 2000}

Bennett PA. Understanding foster parents' perceptions of the behavior of foster children [PhD]. Buffalo: State University of New York at Buffalo, 2000. [MEDLINE: 1915]

\section{BERRICK 1994}

Berrick J, And O. A comparison of kinship foster homes and foster family homes: Implications for kinship foster care as family preservation. Children and Youth Services Review 1994;16(1-2):33-64. [MEDLINE: 3314]

\section{BERRICK 1997}

Berrick JD. Assessing quality of care in kinship and foster family care. Family Relations 1997;46(3):273-280. [MEDLINE: 5440]

\section{BERRICK 1999}

Berrick JD, Needell B. Recent trends in kinship care: Public policy, payments, and outcomes for children. In: The Foster Care Crisis: Translating Research into Policy and Practice. Lincoln: University of Nebraska Press, 1999. [MEDLINE: 5215]

\section{BILAVER 1999}

Bilaver LA, Jaudes PK, Koepke D, Goerge RM. The health of children in foster care. Social Service Review 1999;73(3):401-417. [MEDLINE: 5098]

\section{BROOKS 1998}

Brooks D, Barth RP. Characteristics and outcomes of drug-exposed and non drug-exposed children in kinship and non-relative foster care. Children and Youth Services Review 1998;20(6):475-501. [MEDLINE: 5420] 


\section{CHAMBERLAIN 2006}

Chamberlain P, Price JM, Reid JB, Landsverk J, Fisher PA, Stoolmiller M. Who disrupts from placement in foster and kinship care? Child Abuse \& Neglect 2006;30(4):409-424. [MEDLINE: 4263]

\section{CHAPMAN 2004}

Chapman MV, Wall A, Barth RP. Children's voices: the perceptions of children in foster care. American Journal of Orthopsychiatry 2004;74(3):293-304. [MEDLINE: 4468]

\section{CHEW 1998}

Chew RJ. Development, attachment and play in drug-exposed children of multiple foster care placements [PhD]. Alameda: California School of Professional Psychology at Alameda, 1998.

\section{CHRISTOPHER 1998}

Christopher J. A comparison of foster care teenagers in Kern County: High school graduates vs dropouts (California) [MSW]. Bakersfield: California State University, Bakersfield, 1998.

\section{CLYMAN 1998}

Clyman R, Riley A, Lewin A, Messer S. Service utilization by young children in out-of-home placement. In: A System of Care for Children's Mental Health: Expanding the Research Base, Annual Research Conference Proceedings. 1998:2-7. [MEDLINE: 3066]

\section{COLE 2006}

Cole SA. Building secure relationships: Attachment in kin and unrelated foster caregiver-infant relationships. Families in Society 2006;87(4):497-508. [MEDLINE: 4312]

\section{CONNELL 2006A}

Connell CM, Katz KH, Saunders L, Tebes JK. Leaving foster care - The influence of child and case characteristics on foster care exit rates. Children and Youth Services Review 2006;28(7):780-798. [MEDLINE: 770]

\section{CONNELL 2006B}

Connell CM, Vanderploeg JJ, Flaspohler P, Katz KH, Saunders L, Tebes JK. Changes in placement among children in foster care: a longitudinal study of child and case influences. Social Service Review 2006;80(3):398-418.

[MEDLINE: 4336]

\section{COURTNEY 1995}

Courtney ME. Reentry to foster care of children returned to their families.

Social Service Review 1995;69(2):226-241. [MEDLINE: 5740]

\section{COURTNEY 1996A}

Courtney ME, Barth RP. Pathways of older adolescents out of foster care: Implications for independent living services. Social Work 1996;41(1):75-83. [MEDLINE: 5602]

\section{COURTNEY 1996B}

Courtney ME, Wong YLI. Comparing the timing of exits from substitute care. Children and Youth Services Review 1996;18(4-5):307-334. [MEDLINE: 1409]

\section{COURTNEY 1997A}

Courtney ME, Piliavin I, Wright BRE. Transitions from and returns to out-ofhome care. Social Service Review 1997;71(4):652-667. [MEDLINE: 5450] 


\section{COURTNEY 1997B}

Courtney ME, Needell B. Outcomes of kinship care: Lessons from California. In: Child Welfare Research Review. Vol. 2. New York: Columbia University Press, 1997. [MEDLINE: 5553]

DAVIS 2005

Davis A. Outcomes of African American adolescents in kinship and family foster care: An exploration of racial identity development [PhD]. Albany: University at Albany, State University of New York, 2005.

FRAME 2000

Frame L, Berrick JD, Brodowski ML. Understanding reentry to out-of-home care for reunified infants. Child Welfare 2000;79(4):339-369. [MEDLINE: 1137]

\section{FRAME 2002}

Frame L. Maltreatment reports and placement outcomes for infants and toddlers in out-of-home care. Infant Mental Health Journal 2002;23(5):517540. [MEDLINE: 1098]

FULLER 2005

Fuller TL. Child safety at reunification: A case-control study of maltreatment recurrence following return home from substitute care. Children and Youth Services Review 2005;27(12):1293-1306. [MEDLINE: 837]

\section{GROGAN-KAYLOR 2000}

Grogan-Kaylor AC. The effect of population level characteristics of the foster care caseload on reunification from foster care [PhD]. Madison: University of Wisconsin-Madison, 2000. [MEDLINE: 3965]

\section{HARRIS 2003}

Harris DM. Alabama families and children in formal kinship care, informal kinship care, and unrelated family foster care: A comparative analysis [PhD]. Tuscaloosa: University of Alabama, 2003. [MEDLINE: 3831]

\section{HOLTAN 2005}

Holtan A, Ronning JA, Handegard BH, Sourander A. A comparison of mental health problems in kinship and nonkinship foster care. European Child \& Adolescent Psychiatry 2005;14(4):200-207. [MEDLINE: 850]

\section{IGLEHART 1994}

Iglehart AP. Kinship foster care - Placement, service, and outcome issues. Children and Youth Services Review 1994;16(1-2):107-122. [MEDLINE: 1505]

\section{IGLEHART 1995}

Iglehart AP. Readiness for independence: Comparison of foster care, kinship care, and non-foster care adolescents. Children and Youth Services Review 1995;17(3):417-432. [MEDLINE: 5781]

\section{JENKINS 2002}

Jenkins MH. Quality of care study of 76 kinship and 105 non-kinship foster children [PhD]. New York: Yeshiva University, 2002.

\section{JONES-KARENA 1998}

Jones-Karena, J. Functioning and adjustment of children in kinship care versus nonrelative foster family care placements $[\mathrm{PhD}\}$. Buffalo: State University of New York at Buffalo, 1998. 
JONSON-REID 2003

Jonson-Reid M. Foster care and future risk of maltreatment. Children and

Youth Services Review 2003;25(4):271-294. [MEDLINE: 1053]

\section{LANDSVERK 1996}

Landsverk J, Davis I, Ganger W, Newton R, Johnson I. Impact of child psychosocial functioning on reunification from out-of-home placement.

Children and Youth Services Review 1996;18(4/5):447-462. [MEDLINE: 5653]

\section{LESLIE 2000A}

Leslie LK, Landsverk J, Ezzet-Lofstrom R, Tschann JM, Slymen DJ, Garland

AF. Children in foster care: factors influencing outpatient mental health service use. Child Abuse \& Neglect 2000;24(4):465-476. [MEDLINE: 4948]

\section{MCINTOSH 2002}

Mcintosh MM. Barriers to reunification in the child welfare system: An analysis of kinship and non-kinship placements [MSW]. Long Beach:

California State University, 2002. [MEDLINE: 4803]

MCMILLEN 2004

McMillen JC, Scott LD, Zima BT, Ollie MT, Munson MR, Spitznagel E. Use of mental health services among older youths in foster care. Psychiatric Services 2004;55(7):811-817. [MEDLINE: 4546]

\section{MCMILLEN 2005}

McMillen JC, Zima BT, Scott LD, Auslander WF, Munson MR, Ollie MT, Spitznagel EL. Prevalence of psychiatric disorders among older youths in the foster care system. Journal of the American Academy of Child and Adolescent Psychiatry 2005;44(1):88-95. [MEDLINE: 913]

\section{METZGER 1997}

Metzger JW. The role of social support in mediating the well-being of children placed in kinship foster care and traditional foster care [PhD]. New York: New York University, 1997.

\section{MOSEK 2001}

Mosek A, Adler L. The self-concept of adolescent girls in non-relative versus in kin foster care. International Social Work 2001;44(2):149-162. [MEDLINE: 4904]

\section{RUDENBERG 1991}

Rudenberg MB. The comparison between familial and nonfamilial out-ofhome placement on the self-esteem and behavior of children [PhD]. San Diego, CA: United States International University, 1991. [MEDLINE: 2269]

\section{SALLNAS 2004}

Sallnas M, Vinnerljung B, Kyhle Westermark P, Sallnäs M, Westermark PK. Breakdown of teenage placements in Swedish foster and residential care. Child \& Family Social Work 2004;9(2):141-152. [MEDLINE: 4508]

\section{SCANNAPIECO 1997}

Scannapieco M, Hegar RL, McAlpine C. Kinship care and foster care: A comparison of characteristics and outcomes. Families in Society 1997;78(5):480-487. [MEDLINE: 5437]

\section{SHIN 2003}

Shin SH. Building evidence to promote educational dompetence of youth in foster care. Child Welfare 2003;82(5):615-632. [MEDLINE: 4577] 


\section{SIVRIGHT 2004}

Sivright NL. The role of kinship care in permanency outcomes [PhD]. New

York: Yeshiva University, 2004.

\section{SMITH 2002}

Smith CJ, Rudolph C, Swords P. Kinship care: issues in permanency planning. Children and Youth Services Review 2002;24(3):175-188. [MEDLINE: 4703]

\section{SMITH 2003}

Smith BD. After parental rights are terminated: factors associated with exiting foster care. Children and Youth Services Review 2003;25(12):965-985.

[MEDLINE: 4607]

\section{SRIPATHY 2004}

Sripathy R. Foster parents' perceptions of children's well-being in kinship and non-kinship care [PhD]. Garden City, NY: Adelphi University, 2004.

\section{STRIJKER 2003}

Strijker J, Zandberg T, Van Der Meulen BF. Kinship foster care and foster care in the Netherlands. Children and Youth Services Review 2003;25(11):843-862. [MEDLINE: 1012]

\section{SURBECK 2000}

Surbeck BBC. The social environment's impact on the functioning of children in kinship and nonkinship care [PhD]. New Brunswick: Rutgers, The State University of New Jersey, 2000.

\section{TARREN-SWEENEY 2006}

Tarren-Sweeney M, Hazell P. Mental health of children in foster and kinship care in New South Wales, Australia. Journal of Paediatrics and Child Health 2006;42(3):89-97. [MEDLINE: 794]

\section{TESTA 1999}

Testa MF, Rolock N. Professional foster care: A future worth pursuing? Child Welfare 1999;78(1):108-124. [MEDLINE: 5254]

\section{TESTA 2001}

Testa MF. Kinship care and permanency. Journal of Social Service Research 2001;28(1):25-43. [MEDLINE: 4861]

\section{TIMMER 2004}

Timmer SG, Sedlar G, Urquiza A. Challenging children in kin versus nonkin foster care: Perceived costs and benefits to caregivers. Child Maltreatment 2004;9(3):251-262. [MEDLINE: 4511]

\section{TOMPKINS 2003}

Tompkins W, Jr. Mental and physical health and educational performance outcomes among children in three out-of-home placement types [PhD]. New York: Columbia University, 2003.

\section{VOGEL 1999}

Vogel CA. Using administrative databases to examine factors affecting length of stay in substitute care. Children and Youth Services Review 1999;21(8):677690. [MEDLINE: 1237]

\section{WELLS 1999}

Wells K, Guo S. Reunification and reentry of foster children. Children and

Youth Services Review 1999;21(4):273-294. [MEDLINE: 2729] 
WILSON 1999

Wilson L, Conroy J. Satisfaction of children in out-of-home care. Child

Welfare 1999;78(1):53-69. [MEDLINE: 5150]

ZIMA 2000

Zima BT, Bussing R, Freeman S, Belin TR, Forness SR, Yang X. Behavior problems, academic skill delays and school failure among school-aged children in foster care: Their relationship to placement characteristics. Journal of Child and Family Studies 2000;9(1):87-103. [MEDLINE: 4961]

\section{ZIMMERMAN 1998}

Zimmerman E, Daykin D, Moore V, Wuu C, Li J. Kinship and non-kinship foster care in New York City: Pathways and outcomes. United Way of New York City 1998. [MEDLINE: 5374]

\section{ZURAVIN 1993}

Zuravin SJ, Benedict M, Somerfield M. Child maltreatment in family foster care. American Journal of Orthopsychiatry 1993;63(4):589-596. [MEDLINE: 213]

\subsection{EXCLUDED STUDIES}

\section{ADAMS 1969}

Adamson G. When Auntie or Grannie is Mum. Gabriola Island, Canada: New Society, 1969.

\section{AINSWORTH 1998}

Ainsworth F, Maluccio AN. Kinship care: False dawn or new hope? Australian Social Work 1998;51(4):3-8. [MEDLINE: 5349]

\section{AJDUKOVIC 2004}

Ajdukovic M, Franz BS. Youth self-report of children in children's homes and foster families in Croatia. Drustvena Istrazivanja 2004;13(6):1031-1054.

[MEDLINE: 906]

\section{AJDUKOVIC 2005}

Ajdukovic M, Franz BS. Behavioural and emotional problems of children by type of out-of-home care in Croatia. International Journal of Social Welfare 2005;14(3):163-175. [MEDLINE: 468]

\section{ALMGREN 2001}

Almgren G, Marcenko MO. Emergency room use among a foster care sample: The influence of placement history, chronic illness, psychiatric diagnosis, and care factors. Brief Treatment and Crisis Intervention 2001;1(1):55-64.

[MEDLINE: 1938]

\section{ALTSHULER 1998}

Altshuler SJ. Child well-being in kinship foster care: Similar to, or different from, non-related foster care? Children and Youth Services Review 1998;20(5):369-388. [MEDLINE: 5350]

\section{ALTSHULER 1999}

Altshuler SJ. The well-being of children in kinship foster care. In: J Gleeson, CF Hairston, editor(s). Kinship care: Improving practice through research. Washington, DC: Child Welfare League of America, 1999:117-144. [MEDLINE: 4044] 


\section{ANAUT 1999}

Anaut M, Chouvier B, Tyrrell J. North African and French children placed in care: A comparative study of psychological and educational outcomes. In: Merging Past, Present and Future in Cross-Cultural Psychology: Selected Papers from the 14th International Congress of the International Association for Cross-Cultural Psychology. Swets and Zeitlinger Publishers, 1999.

[MEDLINE: 2022]

\section{ANDERSON 1995}

Anderson GR, Glesson JP. Overview. In: Kinship Care Forum. Chicago:

National Resource Center for Permanency Planning, City University of New

York; Jane Addams Center for Social Policy and Research, University of

Illinois at Chicago, 1995. [MEDLINE: 5821]

\section{AQUILINO 1991}

Aquilino WS. Family structure and home-leaving: A further specification of the relationship. Journal of Marriage and Family 1991;53(4):999-1010.

[MEDLINE: 6223]

\section{ARMSDEN 2000}

Armsden G, Pecora PJ, Payne VH, Szatkiewicz JP. Children placed in longterm foster care: An intake profile using the child behavior checklist/4-18. Journal of Emotional and Behavioral Disorders 2000;8(1):49-64. [MEDLINE: 5063]

\section{BACKOVIC 2006}

Backovic D, Marinkovic JA, Grujicic-Sipetic S, Maksimovic M. Differences in substance use patterns among youths living in foster care institutions and in birth families. Drugs 2006;13(4):341-351. [MEDLINE: 4309]

\section{BARBER 2003}

Barber JG, Delfabbro PH. The first four months in a new foster placement: Psychosocial adjustment, parental contact and placement disruption. Journal of Sociology and Social Welfare 2003;30(2):69-85. [MEDLINE: 529]

\section{BARTH 1995}

Barth RP. The reunification of very young children from foster care. The Source 1995;5(1):1-4. [MEDLINE: 5798]

\section{BASS 2004}

Bass S, Shields MK, Behrman RE. Children, families, and foster care: analysis and recommendations. Future of Children 2004;14(1):4-29. [MEDLINE: 4484]

\section{BEATTY 1995}

Beatty SG. Levels of emotional adjustment in children in foster care [PhD]. Denton: Texas Woman's University, 1995. [MEDLINE: 2129]

\section{BENEDICT 1990}

Benedict MI, White RB. Factors associated with foster care length of stay. Child Welfare 1990;70(1):45-58. [MEDLINE: 6325]

\section{BENEDICT 1994}

Benedict MI, Zuravin S, Brandt D, Abbey H. Types and frequency of child maltreatment by family foster care providers in an urban population. Child Abuse \& Neglect 1994;18(7):577-585. [MEDLINE: 5894] 
Benedict MI, Zuravin S, Stallings RY. Adult functioning of children who lived in kin versus nonrelative family foster homes. Child Welfare 1996;75(5):529549. [MEDLINE: 5621]

\section{BERMAN 2004}

Berman S, Carpener S. Children in foster and kinship care at risk for inadequate health care coverage and access. Findings Brief: Health Care Financing \& Organization 2004;7(4):1-4. [Other: 4479]

\section{BERRICK 1995}

Berrick JD, Needell B, Barth RP. Kinship care in California: An empirically based curriculum. Berkeley Child Welfare Research Center December 1995:151 pp. [MEDLINE: 5820]

\section{BILLING 2002}

Billing A, Macomber JE, Kortenkamp K. Children cared for by relatives: What do we know about their well-being? New federalism: National survey of America's families 2002;Series B(B-46):1-7. [MEDLINE: 4825]

\section{BLUMBERG 1996}

Blumberg E, Landsverk J, Ellismacleod E, Ganger W, Culver S. Use of the public mental health system by children in foster care: Client characteristics and service use patterns. Journal of Mental Health Administration 1996;23(4):389-405. [MEDLINE: 1397]

\section{BROAD 2001}

Broad B. Kinship care: supporting children in placements with extended family and friends. Adoption and Fostering 2001;25(2):33-41. [MEDLINE: 2704]

\section{BROAD 2004}

Broad B. Kinship care for children in the UK: messages from research, lessons for policy and practice. European Journal of Social Work 2004;7(2):211-227. [MEDLINE: 4525]

\section{BROWNE 2005}

Browne K, Hamilton-Giachristis C, Johnson R, Chow S, Ostergren M, Leth I, Agathonos-Georgopoulou H, Anaut M, Herezog M, Keller-Hamela M, Klimackova A, Stan V, Zeytinoglu S. A European survey of the number and characteristics of children less than three years old in residential care at risk of harm. Adoption and Fostering 2005;29(4):23-33. [MEDLINE: 330]

\section{BROWNING 1994}

Browning CJ. Public- and private-sector out-of-home care in Denmark. Social Service Review 1994;68(1):20-32. [MEDLINE: 5889]

\section{CANTOS 1996}

Cantos AL, Gries LT, Slis V. Correlates of therapy referral in foster children.

Child Abuse \& Neglect 1996;20(10):921-931. [MEDLINE: 178]

\section{CARIGLIA 1999}

Cariglia NAP. 'In the best interest of the child...': a study of the kinship care program of the department of social services in Fitchburg, Massachusetts [Phd]. Cambridge, MA: Harvard University, 1999.

\section{CARLSON 2002}

Carlson GLJ. An examination of selected variables affecting the outcomes for adult former foster children placed in Baltimore City: The impact of placement 
stability and type of out-of-home care [PhD]. College Park: University of Maryland, 2002. [MEDLINE: 554]

\section{CARPENTER 2001}

Carpenter SC, Clyman RB, Davidson AJ, Steiner JF. The association of foster care or kinship care with adolescent sexual behavior and first pregnancy.

Pediatrics 2001;108(3):E46. [MEDLINE: 4886]

\section{CARPENTER 2003}

Carpenter SC, Clyman R, Moore L, Xu S, Berman S. Are children in kinship care at greater risk than those in traditional foster care? Pediatric Research 2003;53(4):1099. [MEDLINE: 2582]

\section{CARPENTER 2004A}

Carpenter SC, Berman S, Clyman R, Moore LA, Xu S. Are children in kinship care getting the mental health services they need? Pediatric Research 2004;55(4):1292. [MEDLINE: 2581]

\section{CARPENTER 2004B}

Carpenter SC, Clyman RB. The long-term emotional and physical wellbeing of women who have lived in kinship care. Children and Youth Services Review 2004;26(7):673-686. [MEDLINE: 4516]

\section{CHEN 2000}

Chen, Juhn Lai. Outcomes for children in kin and nonkin placement in foster care [MSW]. Fullerton: California State University, Fullerton, 2000.

\section{CHIPUNGU 1998}

Chipungu SS, Everett JE, Verdieck MJ. Children placed in foster care with relatives: A multi-state study. Executive summary. U.S. Department of Health and Human Services, ACF, ACYF 1998. [MEDLINE: 5372]

\section{CLAWAR 1984}

Clawar SS. Weighing children's opinions... desired living arrangements, family life, educational experiences and foster family care. Children Today 1984;13(5):30-33. [MEDLINE: 450]

\section{CLYMAN 2002}

Clyman RB, Harden BJ. Infants in foster and kinship care. Infant Mental Health Journal 2002;23(5):433-434. [MEDLINE: 4816]

\section{CNNP 1996}

Center for Nutrition Policy and Promotion. Health needs of young children in foster care. Family Economics and Nutrition Review 1996;9(2):36-37.

[MEDLINE: 5611]

\section{COLE 2001}

Cole S. Security of attachment of infants in foster care [PhD]. Cleveland: Case Western Reserve University, 2001. [MEDLINE: 4797]

\section{COLE 2005A}

Cole SA. Foster caregiver motivation and infant attachment: How do reasons for fostering affect relationships? Child and Adolescent Social Work Journal 2005;22(5/6):441-457. [MEDLINE: 4392]

COLE 2005B 
Cole S. Infants in foster care: relational and environmental factors affecting attachment. Journal of Reproductive and Infant Psychology 2005;23(1):43-61. [MEDLINE: 2625]

\section{COLTON 1994}

Colton M, Heath A. Attainment and behavior of children in care and at home.

Oxford Review of Education 1994;20(3):317-327. [MEDLINE: 1477]

\section{COLTON 1995}

Colton M, Heath A, Aldgate J. Factors which influence the educational attainment of children in foster family care. Community Alternatives 1995;7(1):15-36. [MEDLINE: 625]

\section{COURTNEY 1992}

Courtney ME, Barth RP. Pathways from kinship foster care. Berkeley Family Welfare Research Group March 19, 1992:5 pp. [MEDLINE: 6184]

\section{COURTNEY 1994}

Courtney ME. Factors associated with the reunification of foster children with their families. Social Service Review 1994;68(1):80-108. [MEDLINE: 5880]

\section{COURTNEY 1996}

Courtney ME. Kinship foster care and children's welfare: The California experience. Focus 1996;17(3):42-48. [MEDLINE: 5671]

\section{COURTNEY 2001}

Courtney M, Piliavin I, Grogan K, Nesmith A. Foster youth transitions to adulthood: A longitudinal view of youth leaving care. Child Welfare 2001;80(6):685-717. [MEDLINE: 2947]

\section{CRANLEY 2003}

Cranley M, Bianchi JP, Eleson C, Hall L, Jacobson B, Jackson K, Peacock J. Wiskids Count Data Book, 2003. Madison: Wisconsin Council on Children and Families Inc., 2003. [MEDLINE: 2886]

\section{CRAWFORD 2006}

Crawford M. Health of children in out-of-home care: Can we do better?

Journal of Paediatrics and Child Health 2006;42(3):77-78. [MEDLINE: 1665]

\section{CUDDEBACK 2002}

Cuddeback GS, Orme JG. Training and services for kinship and nonkinship foster families. Child Welfare 2002;81(6):879-909. [MEDLINE: 4781]

\section{CWLA 1995}

Child Welfare League of America. Kinship care survey: Summary of initial findings. Washington, DC: Child Welfare League of America, 1995.

\section{DAVIDSON-ARAD 2003}

Davidson-Arad B, Englechin-Segal D, Wozner Y. Short-term follow-up of children at risk: Comparison of the quality of life of children removed from home and children remaining at home. Child Abuse \& Neglect 2003;27(7):733-750. [MEDLINE: 1033]

\section{DAVIS 1993}

Davis IP, Landsverk J, English DJ. Study of reunification risks and successes.

Child and Family Research Group 1993. [MEDLINE: 6072]

\section{DAVIS 1996}


Davis IP, English DJ, Landsverk JA. Outcomes of permanency planning for 1165 foster children. Clearinghouse for Child Abuse and Neglect Information 1996. [MEDLINE: 5812]

\section{DE CADIZ 2006}

De Cadiz BTG, Rivero AM, Balluerka N, Herce C, Achucarro C. Self-concept of children in family foster care: Differences in relation to foster care type, upbringing history, and biological family problems. Infancia Y Aprendizaje 2006;29(2):147-166. [MEDLINE: 768]

\section{DELFABBRO 2002}

Delfabbro PH, Barber JG, Bentham Y. Children's satisfaction with out-ofhome care in South Australia. Journal of Adolescence 2002;25(5):523-533. [MEDLINE: 1092]

\section{DELFABBRO 2003}

Delfabbro P, Barber J, Cooper L. Predictors of short-term reunification in South Australian substitute care. Child Welfare 2003;82(1):27-51. [MEDLINE: 1070]

DU 2002

Du Y, Tang H, Bao Y, Wang Y, Zhen W. Behavior problems of children in special families. Chinese Mental Health Journal 2002;16(1):41-43.

[MEDLINE: 1873]

\section{DUBOWITZ 1990}

Dubowitz H. The physical and mental health and educational status of children placed with relatives. Final report. Division of General Pediatrics, Department of Pediatrics, University of Maryland Medical School 1990. [MEDLINE: 6349]

\section{DUBOWITZ 1992}

Dubowitz H, Feigelman S, Zuravin S, Tepper V, Davidson N, Lichenstein R. The physical health of children in kinship care. American Journal of Diseases of Children 1992;146(5):603-610. [MEDLINE: 224]

\section{DUBOWITZ 1993A}

Dubowitz H, Zuravin S, Starr RH, Feigelman S, Harrington D. Behavior problems of children in kinship care. Journal of Developmental and Behavioral Pediatrics 1993;14(6):386-393. [MEDLINE: 6042]

\section{DUBOWITZ 1993B}

Dubowitz H, Feigelman S, Zuravin S. A profile of kinship care. Child Welfare 1993;72(2):153-169. [MEDLINE: 6030]

\section{DUBOWITZ 1994B}

Dubowitz H, And O. Children in kinship care: How do they fare? Children and Youth Services Review 1994;16(1-2):85-106. [MEDLINE: 3313]

\section{DUBOWITZ 1994C}

Dubowitz H, Sawyer RJ. School behavior of children in kinship care. Child Abuse \& Neglect 1994;18(11):899-911. [MEDLINE: 5899]

\section{DUHRSSEN 1958}

Duhrssen A. The development of institutional and foster home children [Heimkinder und pflegekinder in ihrer entwicklung]. In: Verlag Fur Medizinische Psychologie. Oxford: Verlag Fur Medizinische Psychologie, 1958. [MEDLINE: 2534] 


\section{DWORSKY 2005}

Dworsky A. The economic self-sufficiency of Wisconsin's former foster youth.

Children and Youth Services Review 2005;27(10):1085-1118. [MEDLINE: 844]

\section{EHRLE 2002}

Ehrle J, Geen R. Kin and non-kin foster care: Findings from a national survey. Children and Youth Services Review 2002;24(1/2):15-35. [MEDLINE: 2696]

\section{EHRLE, GEE 2002}

Ehrle J, Geen R. Children cared for by relatives: What services do they need?

New federalism: National survey of America's families 2002; Series B(B-47):17. [MEDLINE: 4824]

\section{ENGLISH 1994}

English DJ. Readiness for independence: A study of youth in foster care.

Children and Youth Services Review 1994;16(3):147-158. [MEDLINE: 600o]

\section{FALCON 2000}

Falcon TA. A comparison of foster care and kinship care adolescents' academic achievement and involvement in the juvenile justice system [MSW]. Long Beach: California State University, Long Beach, 2000. [MEDLINE: 3828]

\section{FARMER 1991}

Farmer E, Parker R. Trials and Tribulations: Returning children from care to their families. London: HMSO, 1991.

\section{FARMER 2001}

Farmer EMZ, Burns BJ, Chapman MV, Phillips SD, Angold A, Costello EJ. Use of mental health services by youth in contact with social services. Social Service Review 2001;75(4):605-624. [MEDLINE: 1169]

\section{FEIGELMAN 1995}

Feigelman S, Zuravin S, Dubowitz H, Harrington D, Starr RH, Tepper V. Sources of health care and health needs among children in kinship care. Archives of Pediatrics \& Adolescent Medicine 1995;149(8):882-886. [MEDLINE: 5750]

FESTINGER 1996

Festinger T. Going home and returning to foster care. Children and Youth Services Review 1996;18(4/5):383-402. [MEDLINE: 5652]

\section{FLINT 1973}

Flint B. A longitudinal study of a group of children reared in a severely depriving environment during infancy and early childhood: Sixteen years investigation. Institute of Child Study, University of Toronto 1973:14. [MEDLINE: 3702]

\section{FOLMAN 1995}

Folman RD. Resiliency and vulnerability among abused and neglected children in foster care [PhD]. Ann Arbor: University of Michigan, 1995. [MEDLINE: 2133]

\section{FONG 2006}

Fong R, Schwab J, Armour M. Continuity of activities and child well-being for foster care youth. Children and Youth Services Review 2006;28(11):1359-1374. [MEDLINE: 4302] 
Franck KL, Buehler C. Kin and family foster care: A focus on needs and services. In: Annual Conference of the National Council on Family Relations. 2002. [MEDLINE: 4765]

\section{FREEDMAN 1994}

Freedman G, Rugs D, Johnston A. Parent reported family functioning in foster and biological families of dependent children. In: A System of Care for Children's Mental Health: Expanding the Research Base, Annual Research Conference Proceedings. 1994:369-372. [MEDLINE: 2585]

\section{GARLAND 2003}

Garland AF, Landsverk JA, Lau AS. Racial/ethnic disparities in mental health service use among children in foster care. Children and Youth Services Review 2003;25(5-6):491-507. [MEDLINE: 1052]

\section{GAUDIN 1993}

Gaudin J, Sutphen R. Foster care vs. extended family care for children of incarcerated mothers. Journal of Offender Rehabilitation 1993;19(3-4):129147. [MEDLINE: 3324]

\section{GEBEL 1996}

Gebel TJ. Kinship care and non-relative family foster care: A comparison of caregiver attributes and attitudes. Child Welfare 1996;75(1):5-18. [MEDLINE: $5644]$

\section{GEEN 2003}

Geen R. Foster children placed with relatives often receive less government help. New Federalism: Issues and Options for States 2003;Series A(A-59):1-5. [MEDLINE: 2903]

\section{GENNARO 1998}

Gennaro S, York R, Dunphy P. Vulnerable infants: Kinship care and health. Pediatric Nursing 1998;24(2):119-125. [MEDLINE: 5354]

\section{GIBBISON 2005}

Gibbison G, Paul C. Foster care and the educational attainment of Jamaican children. Population Research and Policy Review 2005;24(1):107-123.

[MEDLINE: 899]

GIL 1982

Gil E, Bogart K. An exploratory study of self-esteem and quality of care of 100 children in foster care. Children and Youth Services Review 1982;4:351-363. [MEDLINE: 2460]

\section{GOERGE 1995}

Goerge RM, Wulczyn FH, Harden AW. An update from the Multistate Foster Care Data Archive: Foster care dynamics 1983-1993; California, Illinois, Michigan, New York, and Texas. U.S. Department of Health and Human Services, ACYF 1995. [MEDLINE: 5803]

\section{GOTTESMAN 2001}

Gottesman MM. Children in foster care: a nursing perspective on research, policy, and child health issues. Society of Pediatric Nurses Journal 2001;6(2):55-64. [MEDLINE: 4888]

\section{GRAF 1987}

Graf EO. "Careers of placement" of youths in educational establishments [Plazierungskarrieren von Jugendlichen in Erziehungsheimen [German]]. 
Vierteljahresschrift fur Heilpadagogik und ihre Nachbargebiete 1987;56:4760. [MEDLINE: 2352]

\section{GROGAN-KAYLOR 2001}

Grogan-Kaylor A. The effect of initial placement into kinship foster care on reunification from foster care: a bivariate probit analysis. Journal of Social Service Research 2001;27(4):1-31. [MEDLINE: 4860]

\section{GROPPENBACHER 2002}

Groppenbacher E, Hoard C, Miller S. Providing mental health services to young children in foster care: a family-by-family, moment-by-moment approach to change. Zero to Three 2002;22(5):33-37. [MEDLINE: 375]

\section{HAIST 2005}

Haist MP, Jennings ETJ. After the Adoption and Safe Families Act:

Permanency outcomes among children in kinship foster care [PhD].

Lexington: University of Kentucky, 2005.

\section{HANSEN 2004}

Hansen RL, Mawjee FL, Barton K, Metcalf MB, Joye NR. Comparing the health status of low-income children in and out of foster care. Child Welfare 2004;83(4):367-380. [MEDLINE: 4470]

\section{HARDEN 2002}

Harden BJ. Congregate care for infants and toddlers: shedding new light on an old question. Infant Mental Health Journal 2002;23(5):476-495. [MEDLINE: 4746]

\section{HARDEN 2004}

Harden BJ, Clyman RB, Kriebel DK, Lyons ME. Kith and kin care: parental attitudes and resources of foster and relative caregivers. Children and Youth Services Review 2004;26(7):657-671. [MEDLINE: 4519]

\section{HARMAN 2000}

Harman JS, Childs GE, Kelleher KJ. Mental health care utilization and expenditures by children in foster care. Archives of Pediatrics \& Adolescent Medicine 2000;154(11):1114-1117. [MEDLINE: 79]

\section{HESSLE 1989}

Hessle S. Families falling apart: a report from social services. Child Welfare 1989;68:209-13. [MEDLINE: 2821]

\section{HJERN 2004}

Hjern A, Vinnerljung B, Lindblad F. Avoidable mortality among child welfare recipients and intercountry adoptees: A national cohort study. Journal of Epidemiology and Community Health 2004;58(5):412-417. [MEDLINE: 988]

\section{HOLLOWAY 1997}

Holloway JS. Outcome in placements for adoption or long term fostering. Archives of Disease in Childhood 1997;76(3):227-230. [MEDLINE: 1374]

\section{HORNBY 1995}

Hornby H, Zeller D, Karraker D. Kinship care in America: A national policy study. Edmund S. Muskie Institute of Public Affairs, University of Southern Maine 1995. [MEDLINE: 5815]

\section{HORNICK 1989}


Hornick JP, Phillips DM, Kerr N. Gender differences in behavioral problems of foster children: Implications for special foster care. Community Alternatives:

International Journal of Family Care 1989;1:35-52. [MEDLINE: 2319]

HOUSTON 1998

Houston SD. Kinship care vs. traditional foster care: Perceptions of chemically dependent African American mothers [MSW]. Long Beach: California State University, 1998. [MEDLINE: 3821]

\section{HUGHES 1969}

Hughes S. Services to children living with relatives or guardians. Children 1969;16(3):109-113. [MEDLINE: 3807]

\section{HULSEY 1989}

Hulsey TC, White R. Family characteristics and measures of behavior in foster and nonfoster children. American Journal of Orthopsychiatry 1989;59(4):502509. [MEDLINE: 6414]

\section{IAFRATE 2001}

Iafrate R. Family communication and perception of boundaries as predictors of adolescent foster children's well-being [Comunicazione familiare e percezione dei confini come predittori del benessere di adolescenti in affido [Italian]]. Eta Evolutiva 2001;69:72-79. [MEDLINE: 1930]

\section{IGLEHART 2004}

Iglehart AP. Kinship foster care: Filling the gaps in theory, research, and practice. Children and Youth Services Review 2004;26(7):613-621. [MEDLINE: 955]

\section{JACKSON 1994}

Jackson S. Educating children in residential and foster care. Oxford Review of Education 1994;20(3):267-279. [MEDLINE: 1476]

\section{JAFFE 2004}

Jaffe, Deborah Beth. A study of reunification and recidivism in family foster care [MSW]. Long Beach: California State University, 2004. [MEDLINE: 4374]

\section{JAMES 2004A}

James S. Why do foster care placements disrupt? An investigation of reasons for placement change in foster care. Social Service Review 2004;78(4):601627. [MEDLINE: 4550]

\section{JAMES 2004B}

James S, Landsverk J, Slymen DJ. Placement movement in out-of-home care: Patterns and predictors. Children and Youth Services Review 2004;26(2):185206. [MEDLINE: 985]

\section{JANTZ 2002}

Jantz A, Baseman A. Alternative kinship care programs. Children's Voice 2002;11(3):28-32. [MEDLINE: 356]

JEE 2005

Jee SH, Antonucci TC, Aida M, Szilagyi MA, Szilagyi PG. Emergency department utilization by children in foster care. Ambulatory Pediatrics 2005;5(2):102-106. [MEDLINE: 894] 
Jee SH, Barth RP, Szilagyi MA, Szilagyi PG, Aida M, Davis MM. Factors associated with chronic conditions among children in foster care. Journal of Health Care for the Poor and Underserved 2006;17(2):328-341. [MEDLINE: 775 ]

\section{JOHNSON 1995}

Johnson PR, Voss R, Johnson PR, Yoken C. Family foster care placement: The child's perspective. Child Welfare 1995;74(5):959-974. [MEDLINE: 5780]

\section{JONES 1998}

Jones L. The social and family correlates of successful reunification of children in foster care. Children and Youth Services Review 1998;20(4):305-323.

[MEDLINE: 1306]

\section{KAMAIKO 2003}

Kamaiko Solano WD. Developmental outcomes of young children with histories of prenatal drug exposure in foster care placement and the characteristics of the caregiving environment [PhD]. Garden City, NY: Adelphi University, 2003. [MEDLINE: 1832]

\section{KAPPENBERG 2006}

Kappenberg ES, Halpern DF. Kinship center attachment questionnaire: Development of a caregiver-completed attachment measure for children younger than 6 years. Educational and Psychological Measurement 2006;66(5):852-873. [MEDLINE: 743]

\section{KELLER 2001}

Keller TE, Wetherbee K, Le Prohn NS, Payne V, Sim K, Lamont ER. Competencies and problem behaviors of children in family foster care: variations by kinship placement status and race. Children and Youth Services Review 2001;23(12):915-940. [MEDLINE: 4852]

\section{KORTENKAMP 2002}

Kortenkamp K, Ehrle J. The Well-Being of Children Involved with the Child Welfare System: A National Overview. New Federalism: National Survey of America's Families, Series B, No. B-43. Assessing the New Federalism: An Urban Institute Program To Assess Changing Social Policies. Washington DC: Urban Institute, 2002. [MEDLINE: 2952]

\section{KOSENEN 1993}

Kosenen M. Descriptive study of foster and adoptive care services in a Scottish agency. Community Alternative 1993;5(2):126-8.

\section{KUFELDT 1995}

Kufeldt K, Armstrong J, Dorosh M. How children in care view their own and their foster families: A research study. Child Welfare 1995;74(3):695-715. [MEDLINE: 5788]

\section{LAAN 2001}

Laan NMA, Loots GMP, Janssen CGC, Stolk J. Foster care for children with mental retardation and challenging behaviour: A follow-up study. British Journal of Developmental Disabilities 2001;47:3-13.

\section{LE BLANC 1991}

Le Blanc M, Mcduff P, Tremblay RE. Family types, living conditions, operation of family systems and social maladjustment during latency and adolescence in underprivileged milieus. Sante mentale au quebec 1991;16(1):45-75. [MEDLINE: 647] 


\section{LESLIE 2000B}

Leslie LK, Landsverk J, Horton MB, Ganger W, Newton RR. The heterogeneity of children and their experiences in kinship care. Child Welfare United States 2000;79(3):315-334. [MEDLINE: 4949]

\section{LESLIE 2002}

Leslie LK, Gordon JN, Ganger W, Gist K. Developmental delay in young children in child welfare by initial placement type. Infant Mental Health Journal 2002;23(5):496-516. [MEDLINE: 4747]

\section{LESLIE 2005}

Leslie LK, Gordon JN, Meneken L, Premji K, Michelmore KL, Ganger W. The physical, developmental, and mental health needs of young children in child welfare by initial placement type. Journal of Developmental and Behavioral Pediatrics 2005;26(3):177-185. [MEDLINE: 4364]

\section{LEWANDOWSKI 2002}

Lewandowski CA, Pierce L. Assessing the effect of family-centered out-ofhome care on reunification outcomes. Research on Social Work Practice 2002;12(2):205-221. [MEDLINE: 4734]

\section{LEWIS 1987}

Lewis R, Fraser M. Blending informal and formal helping networks in foster care. Children and Youth Services Review 1987;9(3):153-169. [MEDLINE: 2846]

\section{LINK 1996}

Link MK. Permanency outcomes in kinship care: A study of children placed in kinship care in Erie County, New York. Child Welfare 1996;75(5):509-528. [MEDLINE: 5620]

\section{LITROWNIK 2003}

Litrownik AJ, Newton R, Mitchell BE, Richardson KK. Long-term follow-up of young children placed in foster care: Subsequent placements and exposure to family violence. Journal of Family Violence 2003;18(1):19-28. [MEDLINE: 4603]

\section{LUX 2001}

Lux JA. Emotional well-being of children in family foster care: A comparison at entry and discharge. Long Beach: California State University, 2001. [MEDLINE: 3836]

\section{LYMAN 1996}

Lyman S, Bird G. A closer look at self-image in male foster care for adolescents. Social Work 1996;41(1):85-96. [MEDLINE: 3228]

\section{MACINTYRE 1970}

Macintyre JM. Adolescence, identity, and foster family care. Children 1970;17(6):213-217. [MEDLINE: 7080]

\section{MACKINTOSH 2006}

Mackintosh VH, Myers BJ, Kennon SS. Children of incarcerated mothers and their caregivers: Factors affecting the quality of their relationship. Journal of Child and Family Studies 2006;15(5):579-594. [MEDLINE: 4322] 
Maclean K, Gunion M. Learning with care: The education of children looked after away from home by local authorities in Scotland. Adoption and Fostering 2003;27(2):20-31. [MEDLINE: 4584]

\section{MALUCCIO 1999}

Maluccio AN. Foster care and family reunification. In: PA Curtis, G Dale, JC Kendall, editor(s). The foster care crisis: Translating research into policy and practice. Lincoln: University of Nebraska Press University of Nebraska Press, 1999:211-224. [MEDLINE: 5210]

\section{MARINKOVIC 2004}

Marinkovic J, Backovic D, Kocijancic R. Health status of adolescents deprived of parental care. [Zdravstveno stanje adolescenata bez roditeljskog staranja.]. Medicinski Pregled 2004;57(11-12):588-591. [MEDLINE: 4487]

\section{MASCORRO 2003}

Mascorro MI. Factors that relate to competency and behavioral problems in foster care children [PhD]. Minneapolis, MN: Walden University, 2003. [MEDLINE: 1834]

\section{MASON 2003}

Mason M, Castrianno LM, Kessler C, Holmstrand L, Huefner J, Payne V, Pecora PJ, Schmaltz S, Stenslie M. A comparison of foster care outcomes across four child welfare agencies. Journal of Family Social Work 2003;7(2):55-72. [MEDLINE: 4666]

\section{MCLEAN 1996}

McLean B, Thomas R. Informal and formal kinship care populations: A study in contrasts. Child Welfare 1996;75(5):489-505. [MEDLINE: 5662]

\section{MCQUAID 1994}

Mcquaid EL. Foster parent-child relationships [PhD]. Denver: University of Denver, 1994. [MEDLINE: 2178]

\section{MECH 1994}

Mech EV. Life-skills knowledge: A survey of foster adolescents in three placement settings. Children and Youth Services Review 1994;16(3):181-200. [MEDLINE: 5999]

\section{MINNIS 2006}

Minnis H, Everett K, Pelosi AJ, Dunn J, Knapp M. Children in foster care: mental health, service use and costs. European Child \& Adolescent Psychiatry 2006;15(2):63-70. [MEDLINE: 4269]

\section{MINTY 2000}

Minty B. A review of the effects of living long-term in substitute care in the context of a discussion of outcome criteria. Social Work \& Social Sciences Review 2000;8(3):169-193. [MEDLINE: 23]

\section{MITCHELL 2002}

Mitchell BE. Physical health of maltreated children shortly after entry into foster care: Assessment and prediction of documented medical problems and caregiver-reported health status [PhD]. San Diego: San Diego State University/University of California, San Diego, 2002.

\section{MONHEIT 1997}

Monheit L, Mauffret Stephan E, Pandolfo MC, Levi G. Psychological vulnerability and depression in foster care and foster home children 
[Vulnerabilita psicologica e depressione nei bambini in affidamento familiare e istituzionale]. Psichiatria-dell'Infancia-e-dell'Adolescenza 1997;64(2):195-204. [MEDLINE: 2081]

MOORE 2001

Moore J, Palacio Quintin E. Evaluation of multiple attachments and coping strategies of adolescents placed in foster families [L'articulation des attachements multiples et des strategies de coping chez les adolescents places en famille d'accueil [French]]. Revista Interamericana de Psicologia 2001;35(1):127-141. [MEDLINE: 1961]

MOSEK 1993

Mosek A. Well-being and parental contact of foster children in Israel: A different situation from the USA? International Social Work 1993;36(3):261275. [MEDLINE: 2237]

\section{MOUTASSEM 1999}

Moutassem-Mimouni B. Adult outcome of children abandoned at birth in Algeria. A comparative study of the outcome of adults raised in foster families and those raised in an institution. Psychiatrie De L'Enfant 1999;42(2):623645. [MEDLINE: 1205]

\section{NEEDELL 1996}

Needell B. Placement stability and permanence for children entering foster care as infants [PhD]. Berkeley: University of California, Berkeley, 1996.

\section{OYEMADE 1974}

Oyemade A. Institutional care, foster home care or family care? Pediatrics 1974;53(2):248-252. [MEDLINE: 7024]

\section{PAYNE 2000}

Payne H. The health of children in public care. Current Opinion in Psychiatry 2000;13(4):381-388. [MEDLINE: 123]

\section{PEARS 2005}

Pears KC, Fisher PA. Emotion understanding and theory of mind among maltreated children in foster care: Evidence of deficits. Development and Psychopathology 2005;17(1):47-65. [MEDLINE: 884]

\section{PECORA 1998}

Pecora PJ, Le Prohn NS, Nollan KA, Downs AC. How are the children doing? Assessing youth outcomes in family foster care. Outcomes of youth in family foster care 1998. [MEDLINE: 5380]

\section{PECORA 2006}

Pecora PJ, Williams J, Kessler RC, Hiripi E, O'Brien K, Emerson J, Herrick MA, Torres D. Assessing the educational achievements of adults who were formerly placed in family foster care. Child \& Family Social Work 2006;11(3):220-231. [MEDLINE: 4282]

\section{PEREZ 1998}

Perez PL. Kinship care families: Attitudes and barriers toward legal permanency for children in relative placements [MSW]. Long Beach: California State University, 1998. [MEDLINE: 5178] 
Prosser WR. Family structure, substitute care, and educational achievement. Institute for Research on Poverty 1997;Discussion Paper No. 1140-97.

[MEDLINE: 5472]

\section{RITCHIE 2005}

Ritchie C. Looked after children: Time for change? The British Journal of

Social Work 2005;35(5):761-767. [MEDLINE: 4429]

\section{RITTER 2005}

Ritter SA, Finkel B, Wallace J. Provider research on kin caregiver service barriers in New York. The Gerontologist 2005;45(Spl. 2):143. [MEDLINE: 4433]

\section{ROCK 1988}

Rock SL. Frequency of maladaptive behavior in foster children. Early Child Development and Care 1988;30:133-139. [MEDLINE: 6524]

\section{ROMNEY 2006}

Romney SC, Litrownik AJ, Newton RR, Lau A. The relationship between child disability and living arrangement in child welfare. Child Welfare 2006;85(6):965-984. [MEDLINE: 696]

\section{ROY 2000}

Roy P, Rutter M, Pickles A. Institutional care: Risk from family background or pattern of rearing? Journal of Child Psychology \& Psychiatry \& Allied Disciplines 2000;41(2):139-149. [MEDLINE: 4991]

\section{ROY 2006}

Roy P, Rutter M. Institutional care: Associations between inattention and early reading performance. Journal of Child Psychology and Psychiatry 2006;47(5):480-487. [MEDLINE: 786]

\section{RUBIN 2004}

Rubin DM, Alessandrini EA, Feudtner C, Mandell DS, Localio AR, Hadley T. Placement stability and mental health costs for children in foster care.

Pediatrics 2004;113(5):1336-1341. [MEDLINE: 979]

\section{RYAN 2005}

Ryan JP, Testa MF. Child maltreatment and juvenile delinquency: Investigating the role of placement and placement instability. Children and Youth Services Review 2005;27(3):227-249. [MEDLINE: 904]

\section{SAWYER 1994}

Sawyer RJ, Dubowitz H. School performance of children in kinship care. Child Abuse \& Neglect 1994;18(7):587-597. [MEDLINE: 5893]

\section{SCHWARTZ 2005}

Schwartz AE. Facing connective complexity: A comparative study of the effects of kinship foster care and non-kinship foster care placements on the identity of African American adolescents [PhD]. Austin: University of Texas, 2005. [MEDLINE: 1620$]$

\section{SHIN 2004}

Shin SH. Development outcomes of vulnerable youth in the child welfare system. Journal of Human Behavior in the Social Environment 2004;9(1/2):39-56. [MEDLINE: 4537]

\section{SHLONSKY 2002}


Shlonsky AR. Relative permanence: An evaluation of KinGAP, California's subsidized guardianship program for kinship caregivers. Berkeley: University of California, 2002. [MEDLINE: 459]

\section{SHORE 2002}

Shore N, Sim KE, Le Prohn NS, Keller TE. Foster parent and teacher assessments of youth in kinship and non-kinship foster care placements: Are behaviors perceived differently across settings? Children and Youth Services Review 2002;24(1/2):109-134. [MEDLINE: 4707]

SIMARD 1993

Simard M, Vachon J, Moisan M. Problems in reintegrating children placed in foster care into their families [Les difficultes de la reinsertion familiale des enfants places]. Apprentissage-et-Socialisation 1993;16(3):241-252.

[MEDLINE: 2193]

\section{SMITH 1986}

Smith PM. Evaluation of Kent placements. Adoption \& Fostering 1986;10(1):29-33. [MEDLINE: 2395]

\section{SMITHGALL 2004}

Smithgall C, Mason S. Identified problems and service utilization patterns among kinship families accessing mental health services. Journal of Human Behavior in the Social Environment 2004;9(3):41-55. [MEDLINE: 4538]

\section{SOUSA 2005}

Sousa L, Pires S, Galante H. Growing up in foster families: Attachment patterns, psychopathology and parental educational styles impact [Crescer em familias de acolhimento: Padroes de vinculacao, psicopatologia e influencia dos estilos educativos parentais]. Psychologica 2005;40:279-303. [MEDLINE: 1682]

\section{STARR 1999}

Starr RH, Dubowitz H, Harrington D, Feigelman S. Behavior problems of teens in kinship care: Cross-informant reports. In: RL Hegar, M Scannapieco, editor(s). Kinship Foster Care: Policy, practice, and research. USA: Oxford University Press, 1999:193-207. [MEDLINE: 5147]

\section{STIFFMAN 2002}

Stiffman MN, Schnitzer PG, Adam P, Kruse RL, Ewigman BG. Household composition and risk of fatal child maltreatment. Pediatrics 2002;109(4):615621. [MEDLINE: 1155]

\section{STRIJKER 2005}

Strijker J, Zandberg T, Van Der Meulen BF. Typologies and outcomes for foster children. Child and Youth Care Forum 2005;34(1):43-55. [MEDLINE: 4345]

SUN 2003

Sun YM. The well-being of adolescents in households with no biological parents. Journal of Marriage and the Family 2003;65(4):894-909. [MEDLINE: 1008]

\section{SYKES 2002}

Sykes J, Sinclair I, Gibbs I, Wilson K. Kinship and stranger foster carers: How do they compare? Adoption and Fostering 2002;26(2):38-48. [MEDLINE: 4742] 
TAUSSIG 2001

Taussig HN, Clyman RB, Landsverk J. Children who return home from foster care: A 6-year prospective study of behavioral health outcomes in adolescence. Pediatrics 2001;108(1):E10. [MEDLINE: 4887]

\section{TEPPER 1991}

Tepper VJ, Starr RH, Jr., Dubowitz H, Feigelman S, Zuravin S. Mental health of children placed with relatives: Predictors of outcome. In: American

Psychological Association Meeting. San Francisco, CA, 1991:7 pp.. [MEDLINE: 6290]

TESTA 1996

Testa MF, Shook KL, Cohen LS, Woods MG. Permanency planning options for children in formal kinship care. Child Welfare 1996;75(5):451-470.

[MEDLINE: 402]

\section{TESTA 1997}

Testa MF, Shook KL. Kinship foster care: A test of inclusive fitness and other theories of relative caregiving. In: American Sociological Association. 1997.

[MEDLINE: 621]

TESTA 2002

Testa MF, Slack KS. The gift of kinship foster care. Children and Youth

Services Review 2002;24(1/2):79-108. [MEDLINE: 4701]

\section{THOBURN 1989}

Thoburn J. The efectiveness of permanent substitute family placement for older children in care. In: J Hudson, B Galaway, editor(s). The state as parent. Hingham, MA: Kluwer Academic Publishers, 1989:369-385. [MEDLINE: 2598]

\section{THORNTON 1991}

Thornton JL. Permanency planning for children in kinship foster homes. Child Welfare 1991;70(5):593-601. [MEDLINE: 6320]

\section{TROUTMAN 2000}

Troutman B, Ryan S, Cardi M. The effects of foster care placement on young children's mental health. Protecting Children 2000;16(1):30-34. [MEDLINE: 5037]

\section{TURNER 2003}

Turner M, Cogshell T. A comparison between adolescents in single-parent homes and non-parental homes: an assessment of well-being. The

Gerontologist 2003;43(Spl. Iss. 1):317. [MEDLINE: 4626]

\section{UNRAU 2005}

Unrau YA, Grinnell RM. Exploring out-of-home placement as a moderator of help-seeking behavior among adolescents who are high risk. Research on Social Work Practice 2005;15(6):516-530. [MEDLINE: 834]

UNRAU, WEL 2005

Unrau YA, Wells MA. Patteens of foster care service delivery. Children and Youth Services Review 2005;27(5):511-531. [MEDLINE: 898]

\section{USGAO 1999}

United States General Accounting Office. Foster care: Kinship care quality and permanency issues. Report to the Chairman, Subcommittee on Human 
Resources, Committee on Ways and Means, House of Representatives 1999:120pp.. [MEDLINE: 5145]

\section{VALICENTI-MCD 2004}

Valicenti-Mcdermott MR, Demb H. Foster care: Are there differences in the cognitive and psychiatric characteristics of young children with developmental disabilities (DD) in kinship vs. non kinship homes? Pediatric Research 2004;55(4):398. [MEDLINE: 2580]

\section{VDSS 1994}

Virginia Deptartment of Social Services. Kinship care in Virginia. Virginia Deptartment of Social Services 1994;House Document No. 71. [MEDLINE: 5966]

\section{VINNERLJUNG 2005}

Vinnerljung B, Oman M, Gunnarson T. Educational attainments of former child welfare clients: A Swedish national cohort study. International journal of social welfare 2005;14(4):265-276. [MEDLINE: 840]

\section{WADE 2000}

Wade P. Children's Program Outcome Review Team: 1999 Evaluation Results. Nashville, TN: Tennessee State Commission on Children and Youth, 2000.

[MEDLINE: 2990]

\section{WADE 2001}

Wade P. Children's Program Outcome Review Team: 2000 Evaluation Results. Nashville, TN: Tennessee State Commission on Children and Youth, 2001. [MEDLINE: 2976]

\section{WALSH 1981}

Walsh JA, Walsh RA, Stuart M. Risk factors, superior adaptive capacity, and characteristics of the foster home as predictors of maintenance of foster placement. In: Meeting of the Western Psychological Association. Los Angeles, CA, 1981, April. [MEDLINE: 3560]

\section{WEBSTER 2000}

Webster D, Barth RP, Needell B. Placement stability for children in out-ofhome care: A longitudinal analysis. Child Welfare 2000;79(5):614-632. [MEDLINE: 4950]

\section{WILSON, CHI 1996}

Wilson DB, Chipungu SS. Introduction... kinship care. Child Welfare 1996;75(5):387-395. [MEDLINE: 405]

\section{WULCZYN 1992}

Wulczyn FH, George RM. Foster care in New York and Illinois: The challenge of rapid change. Social Service Review 1992;66(2):278-294. [MEDLINE: 1550]

\section{WULCZYN 2004}

Wulczyn F. Family reunification. Future of Children 2004;14(1):94-113. [MEDLINE: 4482]

\section{ZURAVIN 1998}

Zuravin SJ, Benedict M, Stallings R. The adult functioning of former kinship and nonrelative foster care children. In: RL Hegar, M Scannapieco, editor(s). Kinship foster care: Policy, practice, and research. USA: Oxford University Press, 1998:208-222. [MEDLINE: 5143] 


\subsection{STUDIES AWAITING CLASSIFICATION}

\section{BERRIDGE 1987}

Berridge D, Cleaver H. Foster Home Breakdown. Oxford: Blackwell, 1987.

HUNT 1999

Hunt J, MacLeod A. The best-laid plans: Outcomes of judicial decisions in child protection cases. London: The Stationnery Office, 1999.

MILLHAM 1986

Millham S, Bullock R, Hosie K, Haak M. Lost in Care. Aldershot: Gower, 1986.

ROWE 1984

Rowe J, Caine M, Hundleby M, Keane A. Long Term Foster Care. London:

Batsford, 1984.

ROWE 1989

Rowe J, Hundleby M, Garnett L. Child Care Now: a survey of placement patterns. London: BAAF, 1989.

SINCLAIR 2000

Sinclair I, Wilson K, Gibbs I. Supporting Foster Placements. University of York Report to the Department of Health 2000.

\subsection{ONGOING STUDIES}

\subsection{ADDITIONAL REFERENCES}

\section{AIHW 2006}

Australian Institute of Health and Welfare. Child protection Australia 20042005.. Retrieved July 23, 2006 from

www.aihw.gov.au/publications/cws/cpa04-05/cpa04-05.pdf 2006.

\section{AYALA-QUILLEN 1998}

Ayala-Quillen BA. The Adoption and Safe Families Act of 1997 kinship care report: An analysis of key areas. Protecting Children 1998;14(3):12-14.

\section{BARTH 2008}

Barth RP, Guo S, McCrae JS. Propensity score matching strategies for evaluating the success of child and family service programs. Research on Social Work Practice 2008;18:212-222.

\section{BERRICK 1994}

Berrick JD, Barth RP. Research on kinship foster care: What do we know?

Where do we go from here? Children and Youth Services Review 1994;16:1-5.

\section{BERRICK 1998}

Berrick JD. When children cannot remain home: Foster family care and

kinship care. Future of Children 1998;8(1):72-87.

BROAD 2005A 
Broad B. Family and friends care, or kinship care, for children and young people who can no longer live with their parents. In: International Conference of Children and Youth in Emerging and Transforming Societies. Oslo, Norway, 2005, June.

BROAD 2005B

Broad B. Improving the health and well-being of young people leaving care. Dorset, England: Russell House Publishing, 2005.

BROOKS 2002

Brooks SL. Kinship and adoption. Adoption Quarterly 2002;5(3):55-66.

CBS 2007

Central Bureau of Statistics. Statistical Abstract for Israel, 2007. Retrieved August 28, 2008 from www1.cbs.gov.il/reader/shnaton/shnatone_new.htm?CYear $=2007 \& V o l=58 \&$ CSubject=2 2007 .

\section{COHEN 1999}

Cohen JD, Cooper BA. Kinship support network: Edgewood's program model and client characteristics. Children and Youth Services Review 1999;21:311338.

\section{CUDDEBACK 2004}

Cuddeback GS. Kinship and family foster care: A methodological substantive synthesis of research. Children and Youth Services Review 2004;26:623-639.

CWLA 1994

Child Welfare League of America. Kinship care: A natural bridge. Washington, DC: Author, 1994.

\section{DFES 2005}

Department for Education and Skills. Children looked after in England (including adoption and care leavers): 2004-2005. Retrieved on July 23, 2006 from www.dfes-uk.co.uk/ 2005.

DUBOWITZ 1994A

Dubowitz H. Kinship care: Suggestions for future research. Child Welfare 1994;73:553-564.

\section{GEEN 2000}

Geen R. In the interest of children: Rethinking federal and state policies affecting kinship care. Policy \& Practice 2000;58(1):19-27.

\section{GEEN 2004}

Geen R. The evolution of kinship care policy and practice. The Future of Children 2004;14:131-149.

\section{GIBBS 2000}

Gibbs P, Muller U. Kinship foster care moving to the mainstream:

Controversy, policy, and outcomes. Adoption Quarterly 2000;4(2):57-87.

\section{GLEESON 1999}

Gleeson JP. Kinship care as a child welfare service. What do we really know? In: JP Gleeson \& CF Hairston, editor(s). Kinship care: Improving practice through research. Washington, DC: CWLA Press, 1999. 
Goerge R, Wulczyn F, Fanshel D. A foster care research agenda for the '90s. Child Welfare 1994;73:525-549.

HIGGINS 2002

Higgins J, Thompson S. Quantifying heterogeneity in a meta-analysis.

Statistics in Medicine 2002;21(11):1539-1558.

HIGGINS 2003

Higgins J, Thompson S, Deeks J, Altman D. Measuring inconsistency in metaanalyses. BMJ Clinical Research 2003;327(7414):557-560.

\section{HIGGINS 2005}

Higgins JPT, Green S editor(s). Cochrane handbook for systematic reviews of interventions 4.2.5. In: The Cochrane Library, Issue 3, 2005. Chichester, UK: John Wiley \& Sons, Ltd., 2005.

\section{HORNBY 1996}

Hornby H, Zeller D, Karraker D. Kinship care in America: What outcomes should policy seek? Child Welfare 1996;75:397-418.

JUNI 2001

Juni P, Altman DG, Egger M. Systematic reviews in health care: Assessing the quality of controlled clinical trials. BMJ Clinical Research 2001;323(7303):4246.

\section{LEOS-URBEL 2002}

Leos-Urbel J, Bess R, Geen R. The evolution of federal and state policies for assessing and supporting kinship caregivers. Children and Youth Services Review 2002;24:37-52.

MOHER 1999

Moher D, Cook D, Eastwood S, Olkin I, Rennie D, Stroup D. Improving the quality of reports of meta-analyses of randomised controlled trials: The QUOROM statement. Lancet 1999;354:1896-1900.

\section{NAW 2005}

National Assembly of Wales. Adoptions, outcomes, and placements for children looked after by local authorities: Year ending 31 March 2005.

Retrieved July 23, 2006 from

www.dataunitwales.gov.uk/eng/pss.asp?cat=201\&year=2005 2005.

\section{PAXMAN 2006}

Paxman M. Outcomes for children and young people in kinship care. An issue paper. Centre for Parenting \& Research, NSW Department of Community Services 2006.

\section{SCANNAPIECO 1999}

Scannapieco, M, Hegar RL. Kinship foster care in context. In: RL Hegar, M Scannapieco, editor(s). Kinship foster care: Policy, practice, and research. New York: Oxford University Press, 1999:1-13.

\section{SCHMID 2007}

Schmid H. Children and youth at risk in Israel: Findings and recommendations to improve their well-being. Children and Youth Services Review 2007;29:1114-1128. 
Scottish Executive National Statistics. Statistics publication notice: Health and care series: Children's social work statistics 2004-05. Retrieved July 23, 2006 from www.scotland.gov.uk/Publications/2005/10/2791127/11278 2005.

$\mathrm{SN} 2007$

Statistics Norway. Barn med barneverntiltak 31. desember, etter tiltak og fylke, 1987-2006. [ Child welfare recipients 1987-2006]. Retrieved February 26, 2008 from http://www.ssb.no/emner/02/barn og

unge/2008/tabeller/barnevern/barnevo10o.html 2007.

SPENCE 2004

Spence N. Kinship care in Australia. Child Abuse Review 2004;13(4):263-276.

TESTA 1992

Testa MF. Conditions of risk for substitute care. Children and Youth Services Review 1992;14:27-36.

USDHHS 2006A

US Department of Health and Human Services. Child Maltreatment 2004. Washington, DC: US Government Printing Office, 2006.

USDHHS 2006B

U.S. Department of Health and Human Services. The AFCARS report: Preliminary FY 2005 estimates as of September 2006. Retrieved March 4, 2008, from

http://www.acf.hhs.gov/programs/cb/stats_research/afcars/tar/report13.ht m 2006.

WILSON 1996

Wilson DB, Chipungu SS. Introduction. Special edition: Kinship care. Child

Welfare 1996;75:397.

\section{ZURAVIN 1999}

Zuravin SJ, Benedict M, Stallings R. The adult functioning of former kinship and nonrelative foster care children. In: RL Hegar \& M Scannapieco, editor(s). Kinship foster care: Policy, practice, and research. New York: Oxford University Press, 1999. 


\section{Data and analyses}

\subsection{BEHAVIORAL DEVELOPMENT}

\begin{tabular}{lllll}
\hline $\begin{array}{l}\text { Outcome or } \\
\text { Subgroup }\end{array}$ & Studies & Participants & Statistical Method & Effect Estimate \\
\hline $\begin{array}{l}1.1 \text { Behavior } \\
\text { Problems Continuous }\end{array}$ & 7 & 59200 & $\begin{array}{l}\text { Odds Ratio }(\mathrm{M}-\mathrm{H}, \\
\text { Random, } 95 \% \mathrm{Cl})\end{array}$ & $1.13[0.92,1.41]$ \\
\hline $\begin{array}{l}1.2 \text { Adaptive } \\
\text { Behaviors }\end{array}$ & 5 & 1024 & $\begin{array}{l}\text { Std. Mean Difference } \\
\text { (IV, Random, } 95 \% \mathrm{Cl})\end{array}$ & $-0.45[-0.70,-0.19]$ \\
\hline $\begin{array}{l}1.3 \text { Behavioral } \\
\begin{array}{l}\text { Problems } \\
\text { Dichotomous }\end{array}\end{array}$ & 2 & 1659 & $\begin{array}{l}\text { Odds Ratio }(\mathrm{M}-\mathrm{H}, \\
\text { Random, } 95 \% \mathrm{Cl})\end{array}$ & $0.49[0.20,1.20]$ \\
\hline
\end{tabular}

\subsection{MENTAL HEALTH}

\begin{tabular}{lllll}
\hline $\begin{array}{l}\text { Outcome or } \\
\text { Subgroup }\end{array}$ & Studies & Participants & Statistical Method & Effect Estimate \\
\hline $\begin{array}{l}\text { 2.1 Psychiatric } \\
\begin{array}{l}\text { Disorders } \\
\text { Dichotomous }\end{array}\end{array}$ & 4 & 49131 & $\begin{array}{l}\text { Odds Ratio }(\mathrm{M}-\mathrm{H}, \\
\text { Random, } 95 \% \mathrm{Cl})\end{array}$ & $0.46[0.44,0.49]$ \\
\hline $\begin{array}{l}\text { 2.2 Psychiatric } \\
\text { Disorders Continuous }\end{array}$ & 1 & 59 & $\begin{array}{l}\text { Std. Mean Difference } \\
\text { (IV, Random, 95\% Cl) }\end{array}$ & $-0.06[-0.59,0.47]$ \\
\hline $\begin{array}{l}2.3 \text { Well-being } \\
\text { Dichotomous }\end{array}$ & 3 & 317870 & $\begin{array}{l}\text { Odds Ratio }(\mathrm{M}-\mathrm{H}, \\
\text { Random, 95\% Cl) }\end{array}$ & $0.52[0.51,0.53]$ \\
\hline $\begin{array}{l}2.4 \text { Well-being } \\
\text { Continuous }\end{array}$ & 1 & 102 & $\begin{array}{l}\text { Std. Mean Difference } \\
\text { (IV, Random, 95\% Cl) }\end{array}$ & $-0.91[-1.32,-0.51]$ \\
\hline
\end{tabular}

\subsection{PLACEMENT STABILITY}

\begin{tabular}{lllll}
\hline $\begin{array}{l}\text { Outcome or } \\
\text { Subgroup }\end{array}$ & Studies & Participants & Statistical Method & Effect Estimate \\
\hline $\begin{array}{l}3.1 \text { Placement } \\
\text { Settings }\end{array}$ & 4 & 11808 & $\begin{array}{l}\text { Odds Ratio }(\mathrm{M}-\mathrm{H}, \\
\text { Random, } 95 \% \mathrm{Cl})\end{array}$ & $0.36[0.27,0.49]$ \\
\hline 3.2 Reentry & 1 & 88 & $\begin{array}{l}\text { Odds Ratio }(\mathrm{M}-\mathrm{H}, \\
\text { Random, } 95 \% \mathrm{Cl})\end{array}$ & $0.29[0.09,0.94]$ \\
\hline
\end{tabular}




\begin{tabular}{lcclc}
\hline $\begin{array}{l}\text { 3.3 Length of } \\
\text { Placement }\end{array}$ & 5 & 1435 & $\begin{array}{l}\text { Std. Mean Difference } \\
\text { (IV, Random, 95\% Cl) }\end{array}$ & $0.86[-0.98,2.70]$ \\
\hline $\begin{array}{l}3.4 \text { Placement } \\
\text { Disruption }\end{array}$ & 2 & 2377 & $\begin{array}{l}\text { Odds Ratio (M-H, } \\
\text { Random, 95\% Cl) }\end{array}$ & $0.46[0.21,1.02]$ \\
\hline $\begin{array}{l}\text { 3.5 Number of } \\
\text { Placements }\end{array}$ & 2 & 91 & $\begin{array}{l}\text { Std. Mean Difference } \\
\text { (IV, Random, 95\% Cl) }\end{array}$ & $-0.30[-0.98,0.39]$ \\
\hline 3.6 Length of Stay & 5 & 316188 & $\begin{array}{l}\text { Std. Mean Difference } \\
\text { (IV, Random, 95\% Cl) }\end{array}$ & $0.21[-0.07,0.48]$ \\
\hline
\end{tabular}

\subsection{PERMANENCY}

\begin{tabular}{lllll}
\hline $\begin{array}{l}\text { Outcome or } \\
\text { Subgroup }\end{array}$ & Studies & Participants & Statistical Method & Effect Estimate \\
\hline 4.1 Reunification & 7 & 59200 & $\begin{array}{l}\text { Odds Ratio }(\mathrm{M}-\mathrm{H}, \\
\text { Random, } 95 \% \mathrm{Cl})\end{array}$ & $1.13[0.92,1.41]$ \\
\hline 4.2 Adoption & 6 & 58645 & $\begin{array}{l}\text { Odds Ratio }(\mathrm{M}-\mathrm{H}, \\
\text { Random, } 95 \% \mathrm{Cl})\end{array}$ & $2.50[1.05,5.94]$ \\
\hline 4.3 Guardianship & 4 & 56720 & $\begin{array}{l}\text { Odds Ratio }(\mathrm{M}-\mathrm{H}, \\
\text { Random, } 95 \% \mathrm{Cl})\end{array}$ & $0.26[0.10,0.72]$ \\
\hline 4.4 Still in Placement & 7 & 53858 & $\begin{array}{l}\text { Odds Ratio }(\mathrm{M}-\mathrm{H}, \\
\text { Random, } 95 \% \mathrm{Cl})\end{array}$ & $2.24[1.66,3.03]$ \\
\hline
\end{tabular}

\subsection{EDUCATIONAL ATTAINMENT}

\begin{tabular}{lllll}
\hline $\begin{array}{l}\text { Outcome or } \\
\text { Subgroup }\end{array}$ & Studies & Participants & Statistical Method & Effect Estimate \\
\hline 5.1 Graduation & 1 & 66 & $\begin{array}{l}\text { Odds Ratio }(\mathrm{M}-\mathrm{H}, \\
\text { Random, } 95 \% \mathrm{Cl})\end{array}$ & $3.33[1.16,9.59]$ \\
\hline 5.2 Grade Level & 2 & 1101 & $\begin{array}{l}\text { Odds Ratio }(\mathrm{M}-\mathrm{H}, \\
\text { Random, } 95 \% \mathrm{Cl})\end{array}$ & $0.81[0.63,1.04]$ \\
\hline $\begin{array}{l}5.3 \text { Repeated a } \\
\text { Grade }\end{array}$ & 4 & 1111 & $\begin{array}{l}\text { Odds Ratio }(\mathrm{M}-\mathrm{H}, \\
\text { Random, } 95 \% \mathrm{Cl})\end{array}$ & $0.67[0.43,1.05]$ \\
\hline
\end{tabular}

\subsection{FAMILY RELATIONS}

\begin{tabular}{lllll}
\hline $\begin{array}{l}\text { Outcome or } \\
\text { Subgroup }\end{array}$ & Studies & Participants & Statistical Method & Effect Estimate \\
\hline $\begin{array}{l}6.1 \text { Attachment } \\
\text { Continuous }\end{array}$ & 5 & 499 & $\begin{array}{l}\text { Std. Mean Difference } \\
\text { (IV, Random, 95\% Cl) }\end{array}$ & $-0.01[-0.30,0.28]$ \\
\hline 6.2 Conflict & 1 & 61 & $\begin{array}{l}\text { Std. Mean Difference } \\
\text { (IV, Random, 95\% Cl) }\end{array}$ & $-2.20[-2.85,-1.55]$ \\
\hline
\end{tabular}




\begin{tabular}{lcclc}
\hline $\begin{array}{l}6.3 \text { Attachment } \\
\text { Dichotomous }\end{array}$ & 3 & 265 & $\begin{array}{l}\text { Odds Ratio }(\mathrm{M}-\mathrm{H}, \\
\text { Random, } 95 \% \mathrm{Cl})\end{array}$ & $0.88[0.33,2.30]$ \\
\hline
\end{tabular}

\subsection{SERVICE UTILIZATION}

\begin{tabular}{lcclc}
\hline $\begin{array}{l}\text { Outcome or } \\
\text { Subgroup }\end{array}$ & Studies & Participants & Statistical Method & Effect Estimate \\
\hline $\begin{array}{l}7.1 \text { Mental Health } \\
\text { Services }\end{array}$ & 9 & 150724 & $\begin{array}{l}\text { Odds Ratio }(\mathrm{M}-\mathrm{H}, \\
\text { Random, } 95 \% \mathrm{Cl})\end{array}$ & $1.69[1.18,2.42]$ \\
\hline $\begin{array}{l}7.2 \text { Developmental } \\
\text { Services }\end{array}$ & 2 & 47844 & $\begin{array}{l}\text { Odds Ratio }(\mathrm{M}-\mathrm{H}, \\
\text { Random, } 95 \% \mathrm{Cl})\end{array}$ & $1.32[1.22,1.42]$ \\
\hline $\begin{array}{l}7.3 \text { Physician } \\
\text { Services }\end{array}$ & 4 & 212660 & $\begin{array}{l}\text { Odds Ratio }(\mathrm{M}-\mathrm{H}, \\
\text { Random, } 95 \% \mathrm{Cl})\end{array}$ & $2.93[0.46,18.59]$ \\
\hline
\end{tabular}

\subsection{RE-ABUSE}

\begin{tabular}{lcclc}
\hline $\begin{array}{l}\text { Outcome or } \\
\text { Subgroup }\end{array}$ & Studies & Participants & Statistical Method & Effect Estimate \\
\hline $\begin{array}{l}8.1 \text { Recurrence of } \\
\text { Abuse }\end{array}$ & 1 & 139 & $\begin{array}{l}\text { Odds Ratio }(\mathrm{M}-\mathrm{H}, \\
\text { Random, 95\% Cl) }\end{array}$ & $2.11[1.07,4.17]$ \\
\hline $\begin{array}{l}8.2 \text { Institutional } \\
\text { Abuse }\end{array}$ & 2 & 566 & $\begin{array}{l}\text { Odds Ratio }(\mathrm{M}-\mathrm{H}, \\
\text { Random, } 95 \% \mathrm{Cl})\end{array}$ & $0.44[0.27,0.72]$ \\
\hline
\end{tabular}




\section{Figures}

Figure 1: Kinship Care Systematic Review Flow of Included Studies

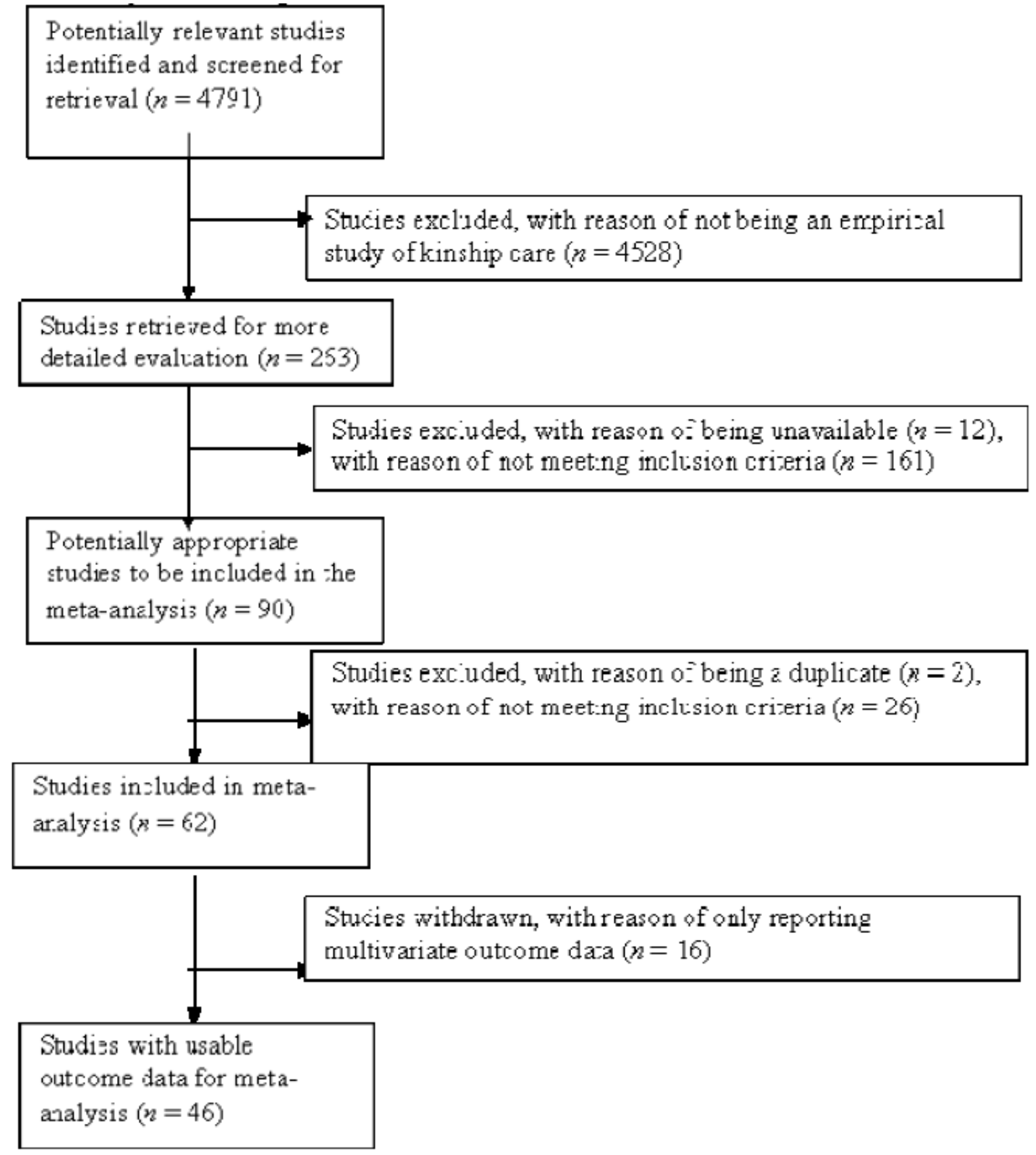




\section{Sources of support}

\subsection{INTERNAL SOURCES}

SFI Campbell, The Danish National Centre for social research, Denmark

\subsection{EXTERNAL SOURCES}

Applied Research in Child Welfare Project, USA 


\section{Appendices}

\subsection{COCHRANE LIBRARY (CENTRAL) SEARCH STRATEGY}

CENTRAL, searched via the Cochrane Library, 2007 (Issue 1)

\#1 (relative near foster*)

\#2 (relative* near substitute)

\#3 (family near foster*)

\#4 (families near foster*)

\#5 (family near substitute)

\#6 (families near substitute)

\#7 (kin near care*)

\#8 (kinship near care*)

\#9 (kinship near caring)

\#10 (\#1 OR \#2 OR \#3 OR \#4 OR \#5 OR \#6 OR \#7 OR \#8 OR \#9)

\#11 MeSH descriptor Adolescent explode all trees

\#12 MeSH descriptor Infant explode all trees

\#13 child near "MESH check words"

\#14 (child* or girl* or boy* or adolescen* or teen* or baby or babies or infant* or

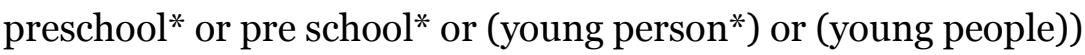

\#15 (\#11 OR \#12 OR \#13 OR \#14)

\#16 (\#10 AND \#15)

\subsection{MEDLINE SEARCH STRATEGY}

MEDLINE, searched via OVID, 1966 to February 2007

1 Child/

2 Infant/

3 Adolescent/

4 (child $\$$ or girl $\$$ or boy $\$$ or adolescent $\$$ or teen $\$$ or baby or babies or infant $\$$ or preschool $\$$ or pre school $\$$ or young person $\$$ or young people).tw.

5 or $/ 1-4$

6 (relative $\$$ adj3 foster\$).tw.

7 (relative $\$$ adj3 substitute).tw.

8 (family adj3 foster\$).tw.

9 (families adj3 foster\$).tw. 
10 (family adj3 substitute).tw.

11 (families adj3 substitute).tw.

12 (kin adj3 care\$).tw.

13 (kinship adj3 care\$).tw.

14 (kin adj3 caring).tw.

15 (kinship adj3 caring).tw.

16 or/6-15

175 and 16

\subsection{C2-SPECTR SEARCH STRATEGY}

Campbell Collaboration's Social, Psychological, Educational, and Criminological

Trials Register (C2-SPECTR) searched March 9th 2007

$\{$ Kin $\}$ or $\{$ kinship\} or $\{$ family or $\{$ families $\}$ or \{relative

AND

\{Foster $\}$ or $\{$ substitute $\}$ or $\{$ care $\}$ or $\{$ caring $\}$

AND

\{Child\} or \{girl\} or $\{$ boy $\}$ or $\{$ adolescent $\}$ or $\{$ teen $\}$ or $\{$ baby $\}$ or $\{$ babies or \{infant $\}$

or $\{$ preschool\} or $\{$ pre school\} or \{young person\}or \{young people\}

\subsection{SOCIOLOGICAL ABSTRACTS SEARCH STRATEGY}

Sociological Abstracts, searched via CSA, 1962 to February 2007

Query: (((relative* within 3 foster*) or (relative* within 3 substitute) or (family within 3 foster*)) or ((families within 3 foster*) or (family within 3 substitute) or (families within 3 substitute)) or ((kin within 3 care $^{*}$ ) or (kinship within 3 care $^{*}$ ) or (kin within 3 caring)) or (kinship near caring) ) and ((DE=("children" or "infants" or "adolescents")) or (child* or girl* or boy* or adolescen* or teen* or baby or babies or infant* or preschool* or pre school* or (young person*) or (young people)))

\subsection{SOCIAL WORK ABSTRACTS SEARCH STRATEGY}

Social Work Abstracts searched 1977 to February 2007

1 (child* or girl* or boy* or adolescent* ${ }^{*}$ or teen* or baby or babies or infant* or

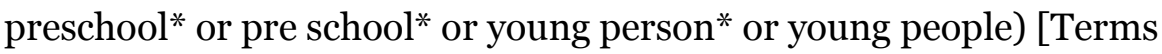
anywhere]

2 (relative* near3 foster*) [Terms anywhere]

3 (relative* near3 substitute) [Terms anywhere]

4 (family near3 foster*) [Terms anywhere] 
5 (families near3 foster ${ }^{*}$ ) [Terms anywhere]

6 (family near3 substitute) [Terms anywhere]

7 (families near3 substitute) [Terms anywhere]

8 (kin near3 care $^{*}$ ) [Terms anywhere]

9 (kinship near3 care $^{*}$ ) [Terms anywhere]

10 (kin near3 caring) [Terms anywhere]

11 (kinship near3 caring) [Terms anywhere]

12 or $/ 2-11$

$13 \quad 1$ and 12

\subsection{SOCIAL SCIENCE CITATION INDEX AND ISI PROCEEDINGS SEARCH STRATEGY}

SSCI, searched 1900 to February 17th 2007, and ISI Proceedings, searched 1990 to February 16th 2007, both accessed via ISI Web of Knowledge,

\#17 \#16 AND \#11

DocType=All document types; Language $=$ All languages;

\#16 \#15 OR \#14 OR \#13 OR \#12

DocType $=$ All document types; Language $=$ All languages;

\#15 TS=(young people)

DocType=All document types; Language=All languages;

\#14 TS=(young person*)

Doc Type=All document types; Language=All languages;

\#13 TS=(baby or babies or infant* or preschool* or pre school*)

DocType $=$ All document types; Language $=$ All languages;

\#12 TS=(child* or girl* or boy* or teen*)

Doc Type=All document types; Language=All languages;

\#11 \#10 OR \#9 OR \#8 OR \#7 OR \#6 OR \#5 OR \#4 OR \# 3 OR \#2 OR \#1

DocType=All document types; Language=All languages;

\#10 TS=(kinship SAME caring)

DocType=All document types; Language=All languages;

\#9 TS=(kin SAME caring)

DocType=All document types; Language=All languages;

\#8 TS=(kinship SAME care*)

DocType=All document types; Language=All languages;

\#7 TS=(kin SAME care*)

DocType=All document types; Language=All languages;

\#6 TS=(families SAME substitute)

DocType=All document types; Language=All languages;

\#5 TS=(family SAME substitute)

DocType=All document types; Language=All languages;

\#4 TS=(families near foster)

Doc Type=All document types; Language=All languages;

\#3 TS=(family SAME foster*) 
DocType $=$ All document types; Language $=$ All languages;

\#2 TS=(relative* SAME substitute)

DocType=All document types; Language=All languages;

\#1 TS=(relative ${ }^{*}$ SAME foster $\left.{ }^{*}\right)$

DocType=All document types; Language=All languages;

\subsection{FAMILY AND SOCIETY STUDIES WORLDWIDE SEARCH STRATEGY}

Family and Society Studies Worldwide searched 1970 to February 2007

1 (child* or girl* or boy* or adolescent* or teen* or baby or babies or infant* or preschool* or pre school* or young person* or young people) [Key words/phrases]

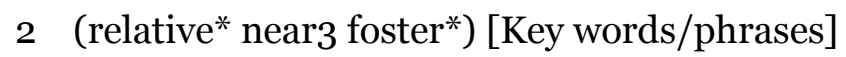

3 (relative* near3 substitute) [Key words/phrases]

4 (family near3 foster*) [Key words/phrases]

5 (families near3 foster*) [Key words/phrases]

6 (family near3 substitute) [Key words/phrases]

7 (families near3 substitute) [Key words/phrases]

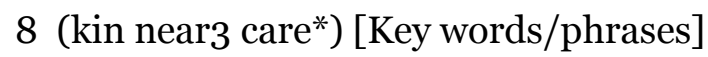

9 (kinship near3 care*) [Key words/phrases]

10 (kin near3 caring) [Key words/phrases]

11 (kinship near3 caring) [Key words/phrases]

12 or/2-11

131 and 12

\subsection{ERIC SEARCH STRATEGY}

ERIC, searched via Dialog DataStar, 1966 to February 2007

1 ERIC - 1966 to date

RELATIVE \$ NEAR FOSTER \$

2 ERIC - 1966 to date

RELATIVE\$ NEAR SUBSTITUTE

3 ERIC - 1966 to date

FAMILY NEAR FOSTER $\$$

4 ERIC - 1966 to date

FAMILIES NEAR FOSTER\$

5 ERIC - 1966 to date

FAMILY NEAR SUBSTITUTE

6 ERIC - 1966 to date

FAMILIES NEAR SUBSTITUTE

7 ERIC - 1966 to date

KIN NEAR CARE\$

8 ERIC - 1966 to date 
KIN NEAR CARING

9 ERIC - 1966 to date

KINSHIP NEAR CARE\$

10 ERIC - 1966 to date

KINSHIP NEAR CARING

11 ERIC - 1966 to date

1 OR 2 OR 3 OR 4 OR 5 OR 6 OR 7 OR 8 OR 9 OR 10

12 ERIC - 1966 to date

CHILD \$ OR GIRL\$ OR BOY\$ OR ADOLESCEN\$ OR TEEN\$ OR BABY OR BABIES

OR INFANT\$ OR PRESCHOOL\$OR PRE ADJ SCHOOL

13 ERIC - 1966 to date

YOUNG ADJ PERSON\$ OR YOUNG ADJ PEOPLE

14 ERIC - 1966 to date

12 OR 13

15 ERIC - 1966 to date

11 AND 14

\subsection{PSYCINFO SEARCH STRATEGY}

PsycINFO, searched via SilverPlatter, 1872 to January week 52007

\#12 ((( (young person*) ) )r( (young people) )) or (child* or boy* or girl* or

adolescen* or teen* or baby or babies or infant* or preschool* or pre school*)) and

((family near3 substitute) or (families near3 foster*) or (family near3 foster*) or (relative* near3 substitute) or (relative* near3 foster*) or (( kin near3 care ${ }^{*}$ )or( kinship near3 care $^{*}$ )or( (kin near3 caring) or (kinship near3 caring) )) or (families near3 substitute))

\#11 (( (young person*) )or( (young people) )) or (child* or boy* or girl* or

adolescen* or teen* or baby or babies or infant* or preschool* or pre school*)

\#10 ( (young person*) )or( (young people) )

\#9 child* or boy* or girl* or adolescen* or teen* or baby or babies or infant* or preschool* or pre school* $^{*}$

\#8 (family near3 substitute) or (families near3 foster*) or (family near3 foster*) or (relative* near3 substitute) or (relative* near3 foster ${ }^{*}$ ) or (( kin near3 care ${ }^{*}$ )or( kinship near3 care* ${ }^{*}$ )or( (kin near3 caring) or (kinship near3 caring) )) or (families near3 substitute)

\#7( kin near3 care* )or( kinship near3 care* )or( (kin near3 caring) or (kinship near3 caring) )

\#6 families near3 substitute 
\#5 family near3 substitute

\#4 families near3 foster*

\#3 family near3 foster*

\#2 relative* near3 substitute

\#1 relative ${ }^{*}$ near3 foster*

\subsection{CINAHL SEARCH STRATEGY}

CINAHL, searched via OVID, 1982 to February week 32007

1 Child/

2 Infant/

3 Adolescent/

4 (child $\$$ or girl\$ or boy $\$$ or adolescent $\$$ or teen $\$$ or baby or babies or infant $\$$ or preschool $\$$ or pre school $\$$ or young person $\$$ or young people).tw.

5 or $/ 1-4$

6 (relative $\$$ adj3 foster\$).tw.

7 (relative $\$$ adj3 substitute).tw.

8 (family adj3 foster\$).tw.

9 (families adj3 foster\$).tw.

10 (family adj3 substitute).tw.

11 (families adj3 substitute).tw.

12 (kin adj3 care\$).tw.

13 (kinship adj3 care\$).tw.

14 (kin adj3 caring).tw.

15 (kinship adj3 caring).tw.

16 or/6-15

175 and 16

\subsection{ASSIA SEARCH STRATEGY}

ASSIA, searched via CSA, 1987 to February 2007

Query: ((DE=("children" or "adolescents" or "babies")) or (child* or girl* or boy* or adolescen* or teen* or baby or babies or infant* or preschool* or pre school* or (young person*) or (young people))) and ((((relative* within 3 foster*) or (relative* within 3 substitute) or (family within 3 foster*)) or ((families within 3 foster ${ }^{*}$ ) or (family within 3 substitute) or (families within 3 substitute)) or ((kin within 3 care $^{*}$ ) or (kinship 
within 3 care $^{*}$ ) or (kin within 3 caring)) or (kinship near caring)) or (DE="kinship foster care"))

\subsection{DISSERTATION ABSTRACTS INTERNATIONAL SEARCH STRATEGY}

Dissertation Abstracts International, accessed via Dissertation Express, searched late 1960 s to February 2007

Search terms used: kinship care, kin care, family foster care 


\section{Data and analyses}

\subsection{BEHAVIORAL DEVELOPMENT OUTCOMES}

Comparison 1 Behavioral Development, Outcome 1 Behavior Problems (Continuous)

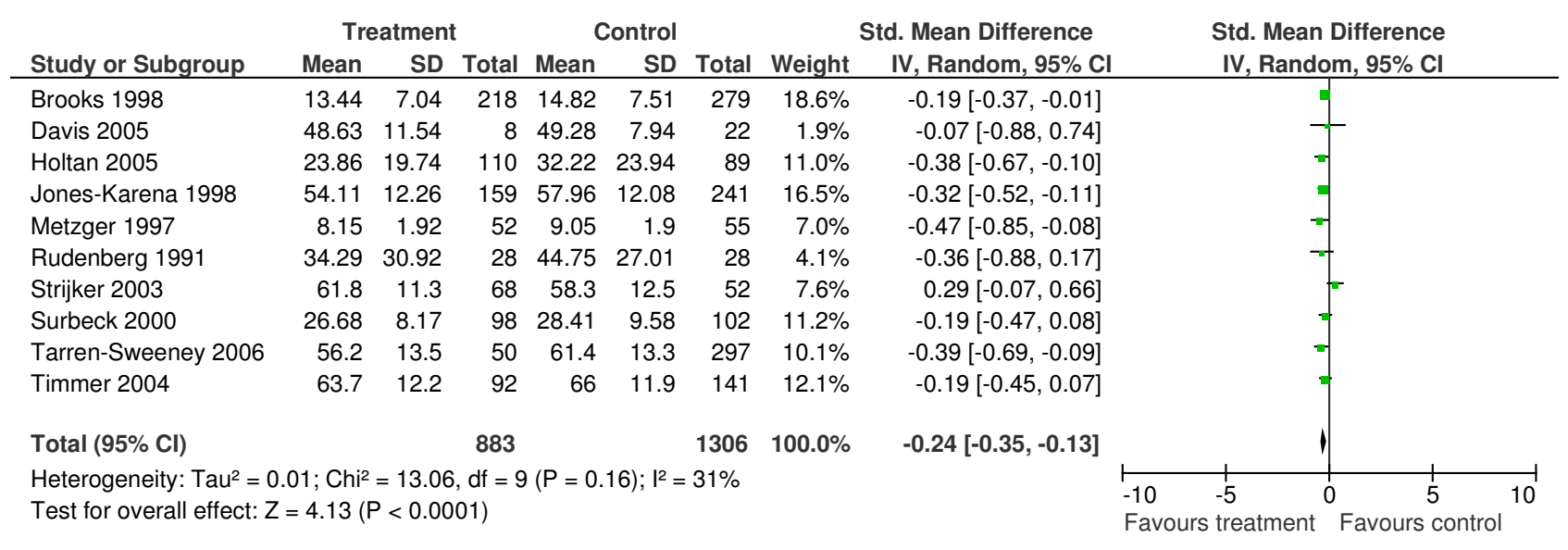

Comparison 1 Behavioral Development, Outcome 2 Adaptive Behaviors

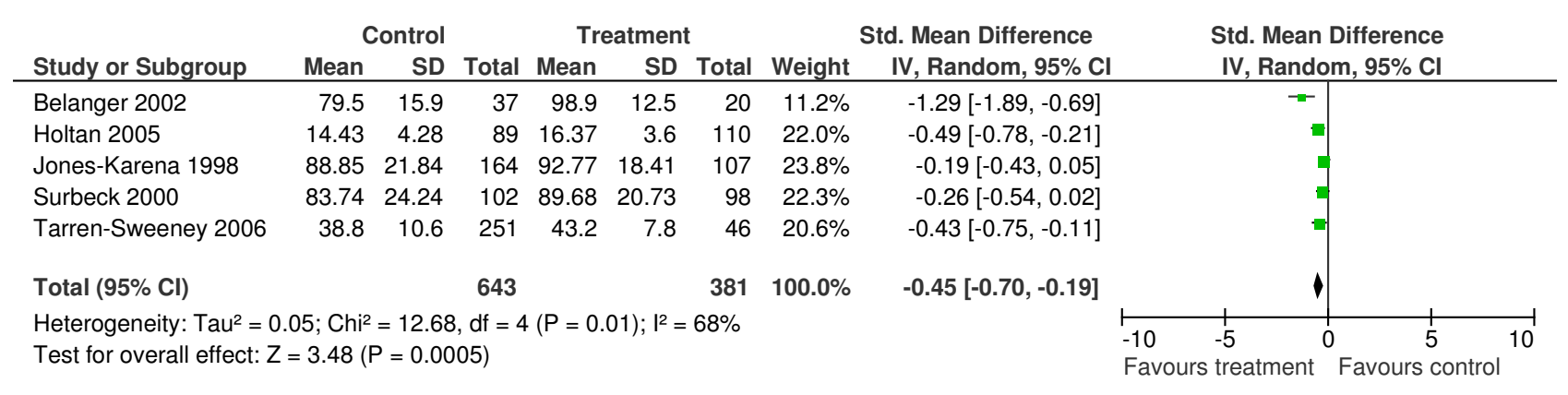


Comparison 1 Behavioral Development, Outcome 3 Behavioral Problems (Dichotomous)

\begin{tabular}{|c|c|c|c|c|c|c|c|}
\hline Study or Subgroup & \multicolumn{2}{|c|}{ Treatment } & \multicolumn{2}{|c|}{ Control } & Weight & $\begin{array}{l}\text { Odds Ratio } \\
\text { M-H, Random, 95\% Cl }\end{array}$ & $\begin{array}{c}\text { Odds Ratio } \\
\text { M-H, Random, } 95 \% \mathrm{Cl}\end{array}$ \\
\hline Iglehart 1994 & 101 & 352 & 219 & 638 & $50.4 \%$ & $0.77[0.58,1.02]$ & \\
\hline Landsverk 1996 & 94 & 298 & 222 & 371 & $49.6 \%$ & $0.31[0.22,0.43]$ & \\
\hline Total $(95 \% \mathrm{Cl})$ & & 650 & & 1009 & $100.0 \%$ & $0.49[0.20,1.20]$ & \\
\hline Total events & 195 & & 441 & & & & \\
\hline $\begin{array}{l}\text { Heterogeneity: } \mathrm{Tau}^{2}= \\
\text { Test for overall effect }\end{array}$ & $\begin{array}{l}.39 ; \mathrm{Chi}^{2} \\
=1.57(\mathrm{P}\end{array}$ & $\begin{array}{l}=17.48 \\
=0.12\end{array}$ & $\mathrm{df}=1$ & $P<0.0$ & $001) ;\left.\right|^{2}=$ & $4 \%$ & 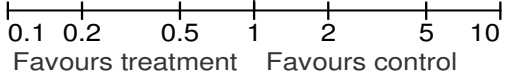 \\
\hline
\end{tabular}

\subsection{MENTAL HEALTH}

Comparison 2 Mental Health, Outcome 1 Psychiatric Disorders (Dichotomous)

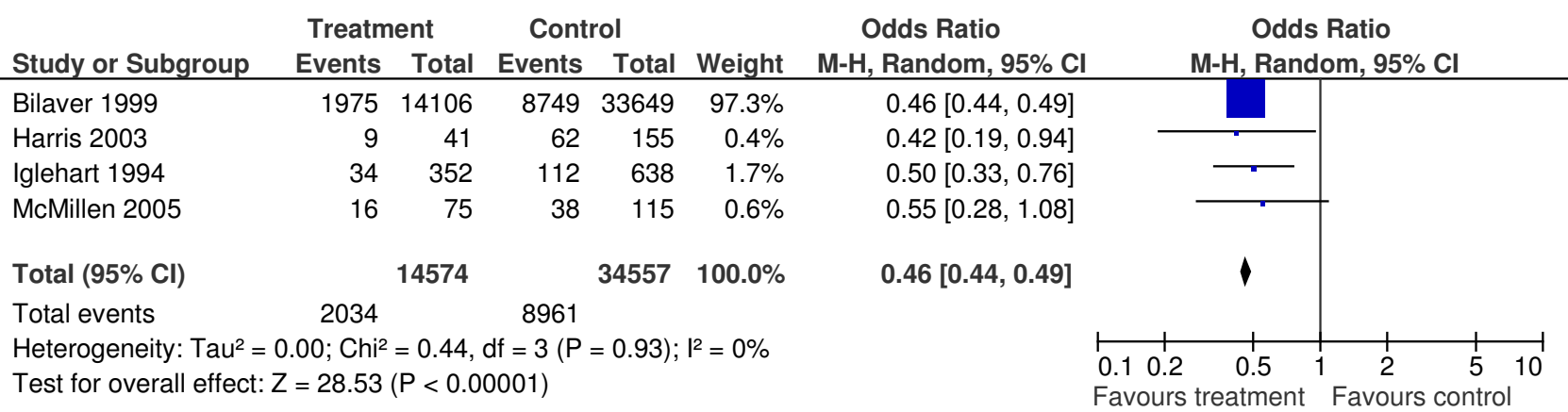


Comparison 2 Mental Health, Outcome 2 Psychiatric Disorders (Continuous)

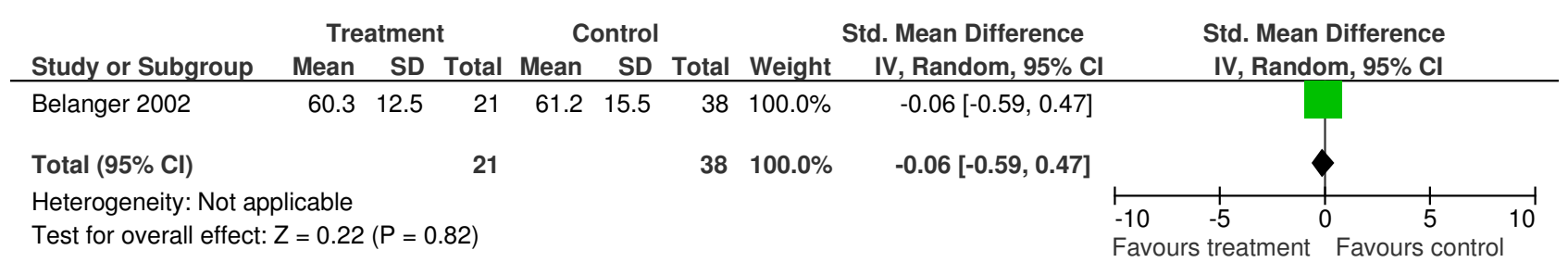

Comparison 2 Mental Health, Outcome 3 Well-being (Dichotomous)

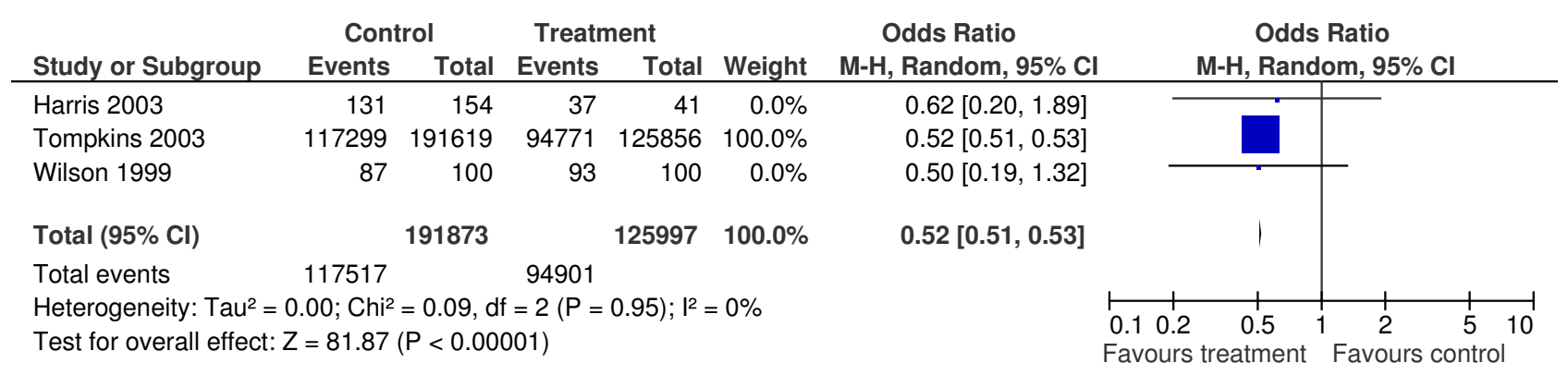

Comparison 2 Mental Health, Outcome 3 Well-being (Continuous)

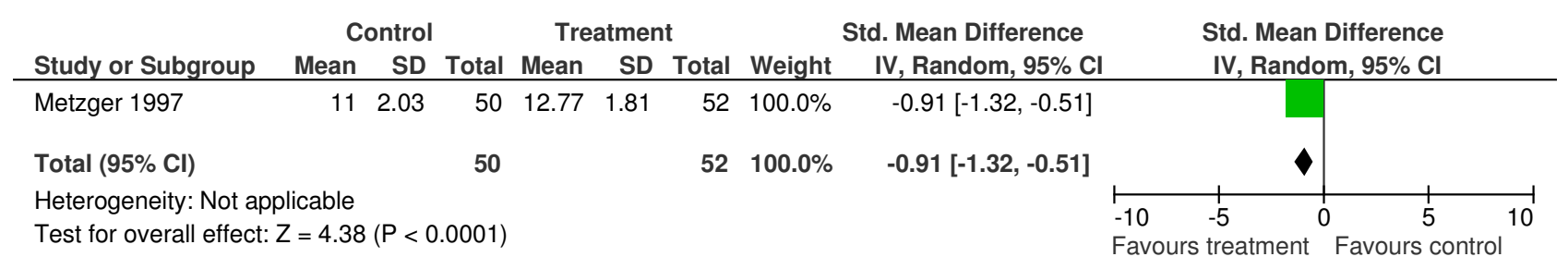




\subsection{PLACEMENT STABILITY OUTCOMES}

Comparison 3 Placement Stability, Outcome 1 Placement Settings

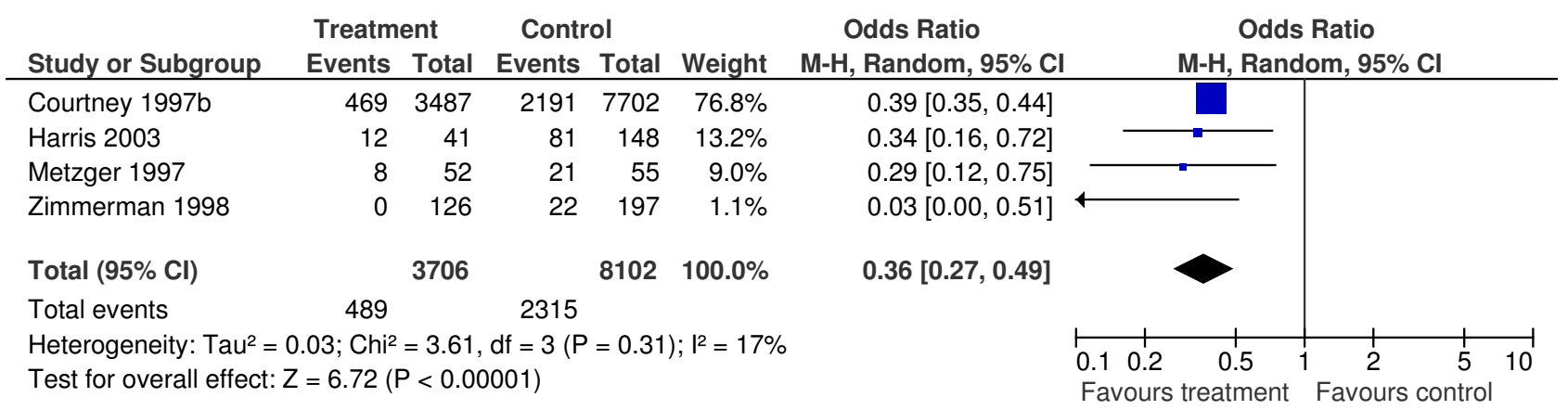

Comparison 3 Placement Stability, Outcome 2 Reentry

\begin{tabular}{|c|c|c|c|c|c|c|c|c|c|c|}
\hline Study or Subgroup & Treatment & $\begin{array}{l}\text { ent } \\
\text { Total }\end{array}$ & \multicolumn{2}{|c|}{ Control } & Weight & $\begin{array}{c}\text { Odds Ratio } \\
\text { M-H, Random, } 95 \% \mathrm{Cl}\end{array}$ & \multicolumn{3}{|c|}{$\begin{array}{c}\text { Odds Ratio } \\
\text { M-H, Random, } 95 \% \text { Cl }\end{array}$} & \\
\hline Frame 2000 & 4 & 26 & 24 & 62 & $100.0 \%$ & $0.29[0.09,0.94]$ & $\leftarrow$ & & & \\
\hline Total $(95 \% \mathrm{Cl})$ & & 26 & & 62 & $100.0 \%$ & $0.29[0.09,0.94]$ & & & & \\
\hline Total events & 4 & & 24 & & & & & & & \\
\hline $\begin{array}{l}\text { Heterogeneity: Not ap } \\
\text { Test for overall effect: }\end{array}$ & $\begin{array}{l}\text { licable } \\
=2.07(\mathrm{~F}\end{array}$ & $=0.04$ & & & & & $\begin{array}{l}1 \\
0.10 .2 \\
\text { Favours }\end{array}$ & $\begin{array}{c}0.5 \\
\text { treatmen }\end{array}$ & $\begin{array}{lc}1 & 2 \\
t \quad \text { Favours con }\end{array}$ & $\begin{array}{ll}+1 \\
5 \\
\text { trol }\end{array}$ \\
\hline
\end{tabular}


Comparison 3 Placement Stability, Outcome 3 Length of placement

Treatment Control Odds Ratio

Study or Subgroup Events Total Events Total Weight $\mathrm{M}-\mathrm{H}, \mathrm{Random}, 95 \% \mathrm{Cl}$ $0.29[0.09,0.94]$

Odds Ratio Frame 2000 26

Total $(95 \% \mathrm{Cl})$ $24 \quad 62 \quad 100.0 \%$ $0.29[0.09,0.94]$

Total events 4

$62100.0 \%$

Heterogeneity: Not applicable

Test for overall effect: $Z=2.07(P=0.04)$

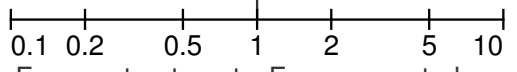

Favours treatment Favours control

Comparison 3 Placement Stability, Outcome 4 Placement disruption

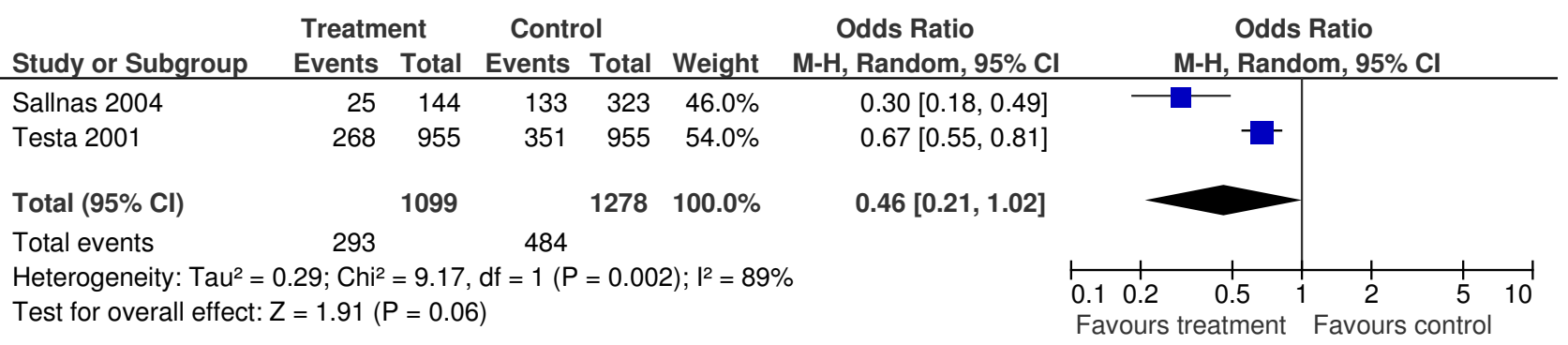


Comparison 3 Placement Stability, Outcome 5 Number of placements

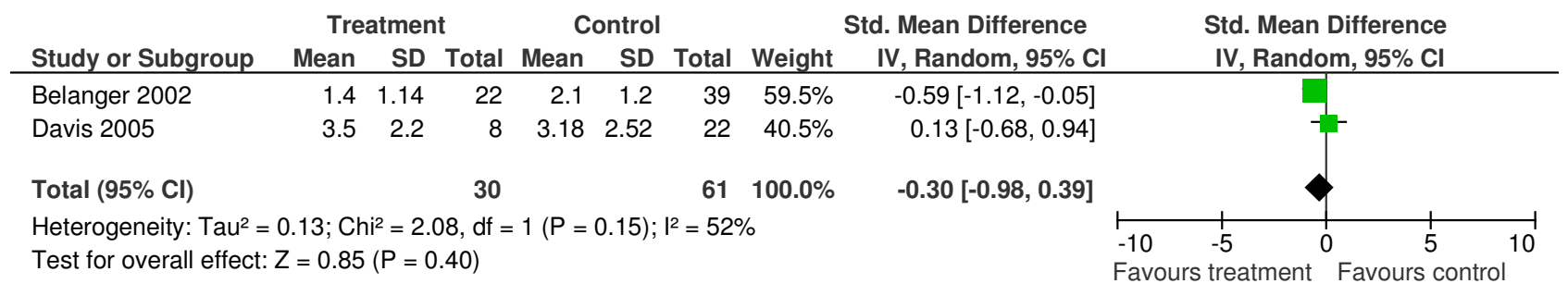

Comparison 3 Placement Stability, Outcome 6 Length of stay

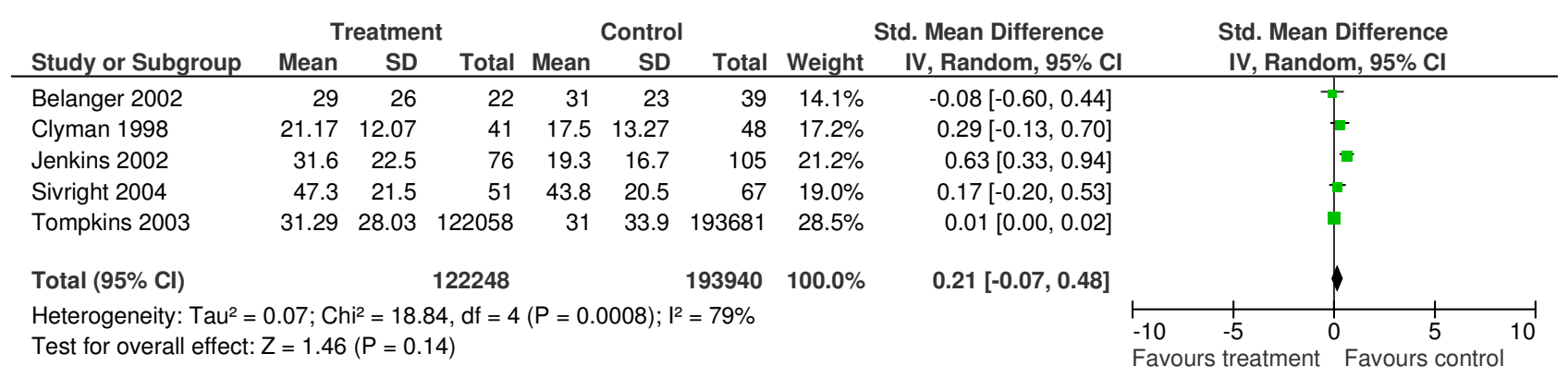




\subsection{PERMANENCY OUTCOMES}

Comparison 4 Permanency, Outcome 1 Reunification

\begin{tabular}{|c|c|c|c|c|c|c|c|c|}
\hline \multirow[b]{2}{*}{ Study or Subgroup } & \multicolumn{2}{|c|}{ Control } & \multicolumn{2}{|c|}{ Treatment } & \multirow[b]{2}{*}{ Weight } & Odds Ratio & \multirow{2}{*}{\multicolumn{2}{|c|}{$\begin{array}{c}\text { Odds Ratio } \\
\text { M-H, Random, } 95 \% \mathrm{Cl}\end{array}$}} \\
\hline & Events & Total & Events & Total & & M-H, Random, $95 \% \mathrm{Cl}$ & & \\
\hline Berrick 1999 & 18816 & 32586 & 7703 & 15739 & $25.0 \%$ & $1.43[1.37,1.48]$ & & 口 + n \\
\hline Mcintosh 2002 & 26 & 54 & 17 & 39 & $5.3 \%$ & $1.20[0.53,2.75]$ & & \\
\hline Smith 2002 & 7 & 36 & 7 & 39 & $3.0 \%$ & $1.10[0.35,3.53]$ & & \\
\hline Testa 1999 & 280 & 4003 & 160 & 2159 & $20.6 \%$ & $0.94[0.77,1.15]$ & & \\
\hline Testa 2001 & 60 & 955 & 54 & 955 & $14.1 \%$ & $1.12[0.77,1.63]$ & & \\
\hline Wells 1999 & 206 & 1157 & 205 & 1155 & $20.2 \%$ & $1.00[0.81,1.24]$ & & \\
\hline Zimmerman 1998 & 90 & 197 & 52 & 126 & $11.9 \%$ & $1.20[0.76,1.88]$ & & \\
\hline Total (95\% Cl) & & 38988 & & 20212 & $100.0 \%$ & $1.13[0.92,1.41]$ & & \\
\hline Total events & 19485 & & 8198 & & & & & \\
\hline $\begin{array}{l}\text { Heterogeneity: } \text { Tau}^{2}= \\
\text { Test for overall effect }\end{array}$ & $\begin{array}{l}.05 ; \mathrm{Chi}^{2} \\
=1.15(\mathrm{~F}\end{array}$ & $\begin{array}{l}=27.03 \\
P=0.25)\end{array}$ & $\mathrm{df}=6$ & $=0.00$ & $1) ;\left.\right|^{2}=7 \varepsilon$ & & $\begin{array}{lll} & 1 & 1 \\
0.1 & 0.2 & 0.5 \\
\text { Favours treatme }\end{array}$ & $\begin{array}{c}1 \\
2 \\
\text { Favours } 0\end{array}$ \\
\hline
\end{tabular}

Comparison 4 Permanency, Outcome2 Adoption

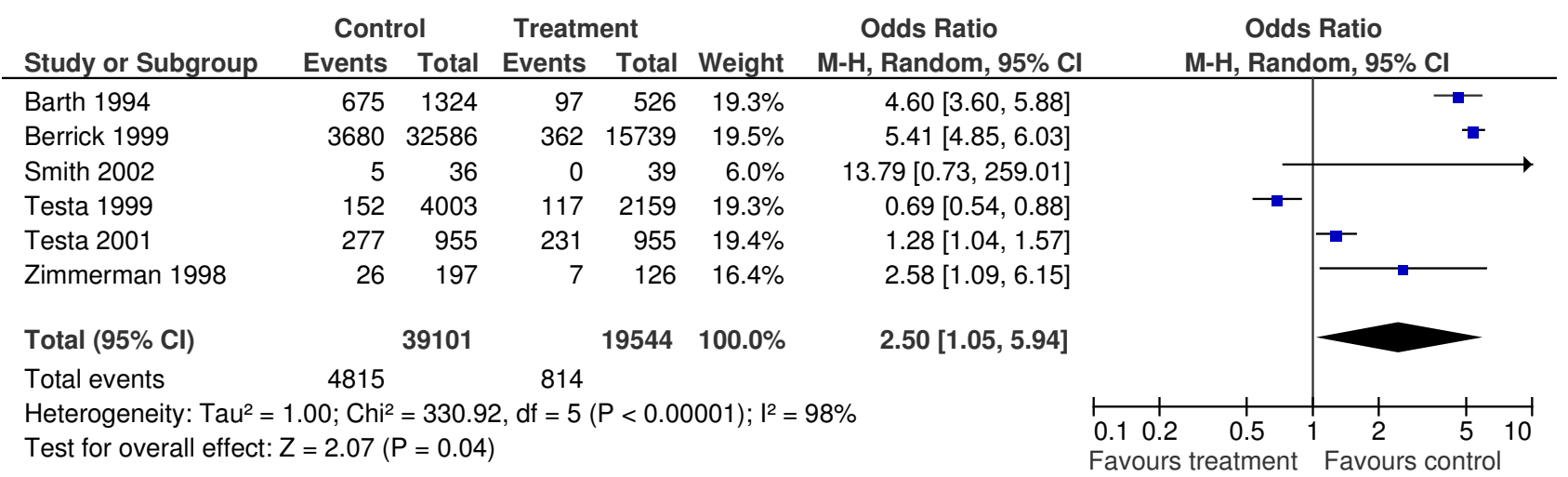


Comparison 4 Permanency, Outcome 3 Guardianship

\begin{tabular}{|c|c|c|c|c|c|c|c|c|}
\hline \multirow[b]{2}{*}{ Study or Subgroup } & \multicolumn{2}{|c|}{ Control } & \multicolumn{2}{|c|}{ Treatment } & \multirow[b]{2}{*}{ Weight } & \multirow{2}{*}{$\begin{array}{c}\text { Odds Ratio } \\
\text { M-H, Random, } 95 \% \text { Cl }\end{array}$} & \multirow{2}{*}{\multicolumn{2}{|c|}{$\begin{array}{c}\text { Odds Ratio } \\
\text { M-H, Random, } 95 \% \mathrm{Cl}\end{array}$}} \\
\hline & Events & Total & Events & Total & & & & \\
\hline Berrick 1999 & 380 & 32586 & 972 & 15739 & $28.6 \%$ & $0.18[0.16,0.20]$ & & \\
\hline Testa 1999 & 3 & 4003 & 33 & 2159 & $20.5 \%$ & $0.05[0.01,0.16]$ & $\longleftarrow$ & \\
\hline Testa 2001 & 19 & 955 & 89 & 955 & $26.8 \%$ & $0.20[0.12,0.33]$ & $\rightarrow$ & \\
\hline Zimmerman 1998 & 28 & 197 & 8 & 126 & $24.1 \%$ & $2.44[1.08,5.55]$ & & \\
\hline Total $(95 \% \mathrm{Cl})$ & & 37741 & & 18979 & $100.0 \%$ & $0.26[0.10,0.72]$ & & \\
\hline Total events & 430 & & 1102 & & & & & \\
\hline $\begin{array}{l}\text { Heterogeneity: } \mathrm{Tau}^{2}= \\
\text { Test for overall effect: }\end{array}$ & $\begin{array}{l}.91 ; \mathrm{Chi}^{2} \\
=2.61\end{array}$ & $\begin{array}{l}=43.32 \\
=0.00\end{array}$ & $\begin{array}{l}\mathrm{df}=3(\mathrm{P} \\
9)\end{array}$ & $<0.00$ & $01) ; l^{2}=9$ & & $\begin{array}{lll}0.1 & 0.2 & 0.5 \\
\text { Favours treatment }\end{array}$ & $\begin{array}{ccc}1 & 2 & 5 \\
\text { Favours control }\end{array}$ \\
\hline
\end{tabular}

Comparison 4 Permanency, Outcome 4 Still in placement

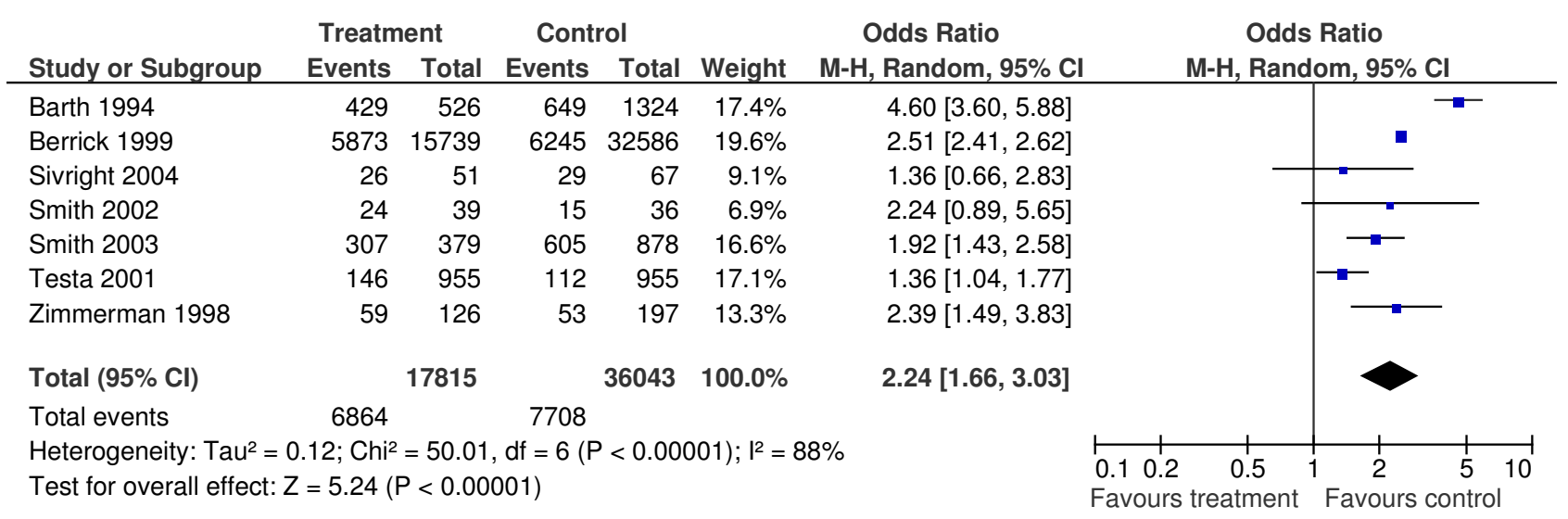




\subsection{EDUCATION ATTAINMENT OUTCOMES}

Comparison 5 Education Attainment, Outcome 1 Graduation

Control Treatment Odds Ratio Odds Ratio

Study or Subgroup Events Total Events Total Weight $\mathrm{M}-\mathrm{H}$, Random, $95 \% \mathrm{Cl} \quad \mathrm{M}-\mathrm{H}, \mathrm{Random}, 95 \% \mathrm{Cl}$

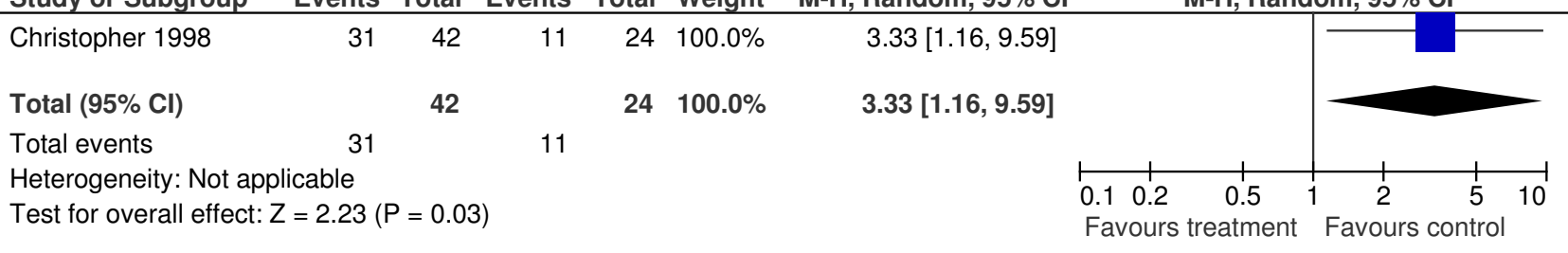

Comparison 5 Education Attainment, Outcome 2 Grade level

Control Treatment Odds Ratio Odds Ratio

Study or Subgroup Events Total Events Total Weight $\mathrm{M}-\mathrm{H}$, Random, 95\% Cl $\quad \mathrm{M}-\mathrm{H}, \mathrm{Random}, 95 \% \mathrm{Cl}$

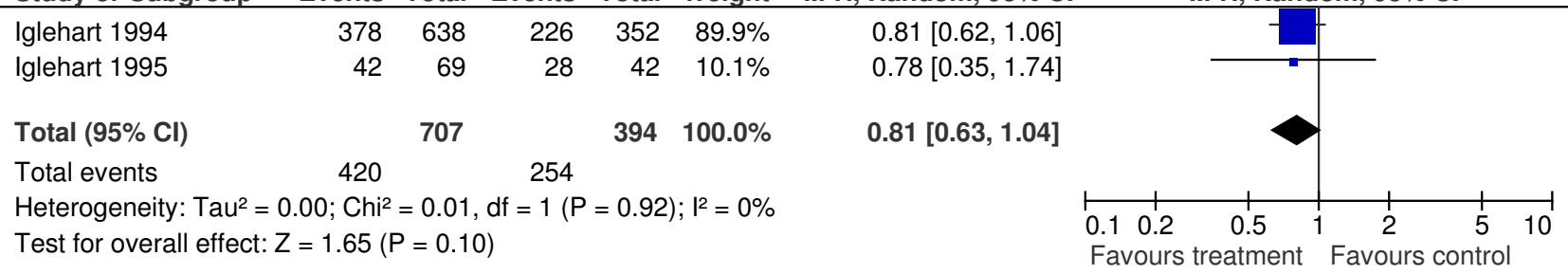


Comparison 5 Education Attainment, Outcome 3 Repeated a grade

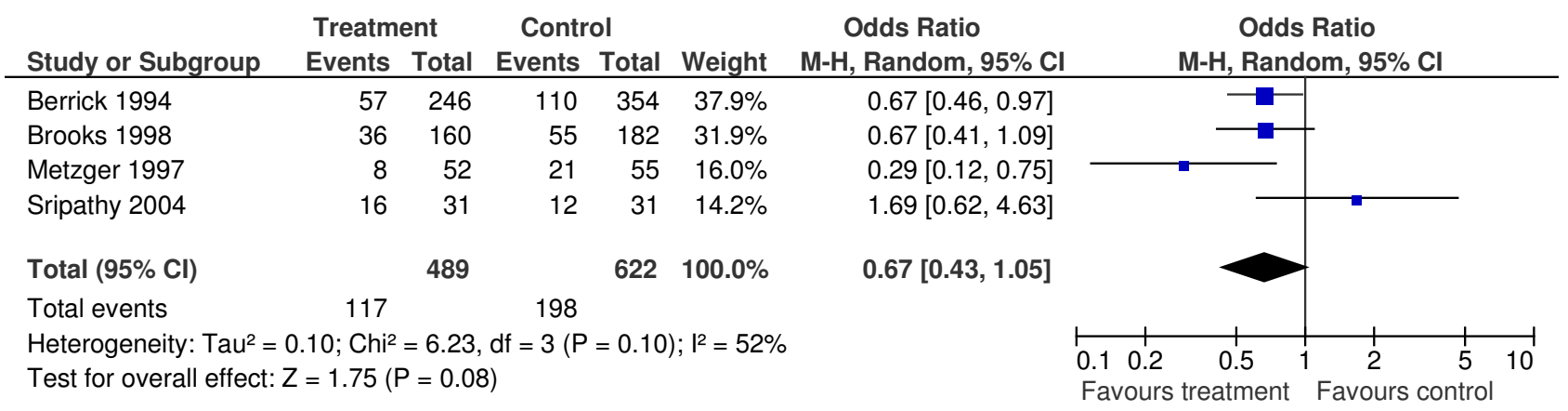

\subsection{FAMILY RELATIONS}

Comparison 6 Family Relations, Outcome 1 Attachment (Continuous)

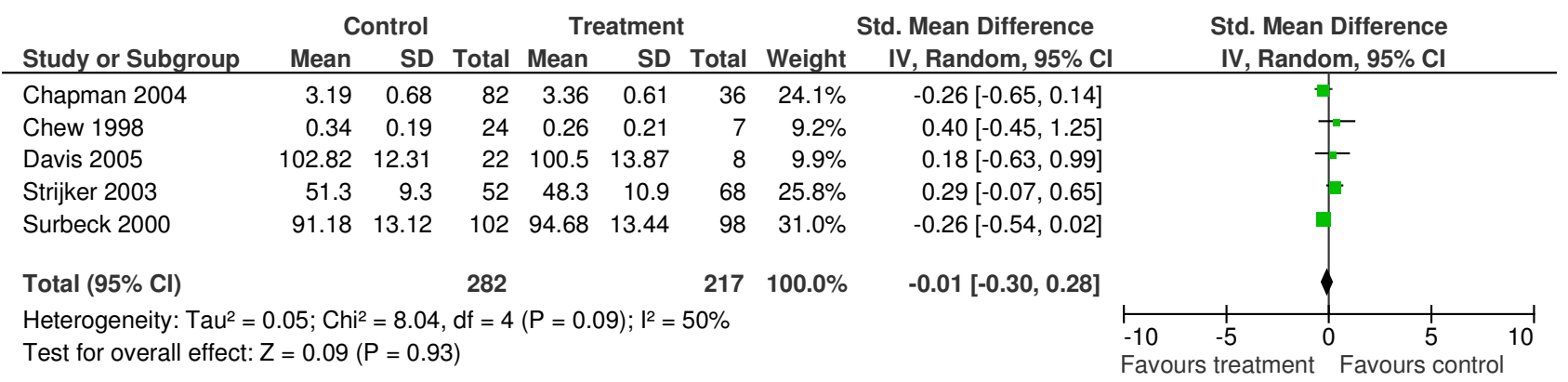

Comparison 6 Family Relations, Outcome 2 Conflict

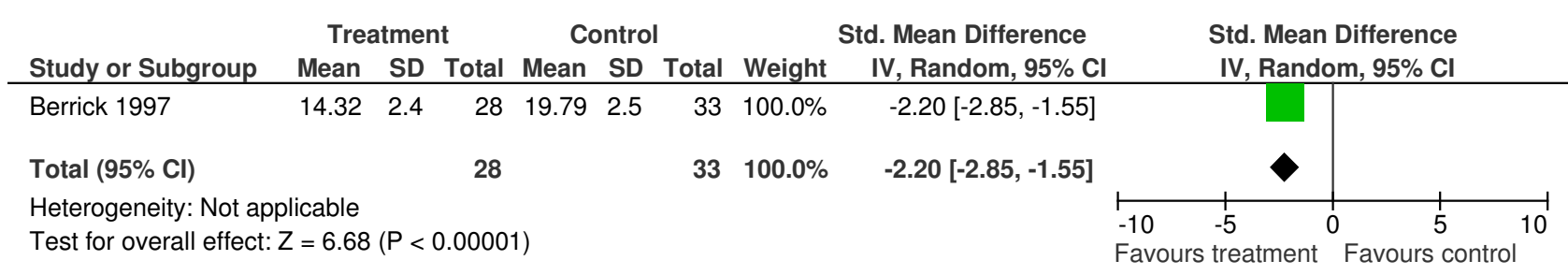


Comparison 6 Family Relations, Outcome 3 Attachment (Dichotomous)

Control Treatment Odds Ratio Study or Subgroup Events Total Events Total Weight M-H, Random, 95\% Cl Cole 2006

Jenkins 2002

Mosek 2001

Total $(95 \% \mathrm{Cl})$

Total events

$\begin{array}{lll}8 & 12 & 27.0 \%\end{array}$

Heterogeneity: $\mathrm{Tau}^{2}=0.39 ; \mathrm{Chi}^{2}=4.23, \mathrm{df}=2(\mathrm{P}=0.12) ; \mathrm{I}^{2}=53 \%$

Test for overall effect: $Z=0.27(P=0.79)$

$23 \quad 34$

$86 \quad 105$

$4 \quad 18$

$57-76 \quad 46.4 \%$

$10 \quad 20 \quad 26.6 \%$

$1.05[0.26,4.23]$
$1.51[0.74,3.10]$
$0.29[0.07,1.18]$

$0.88[0.33,2.30]$

$108 \quad 100.0 \%$

\section{5}

113

(0)

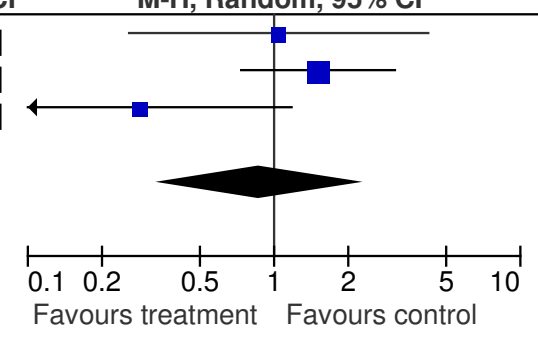

Favours treatment Favours control

Odds Ratio

M-H, Random, 95\% Cl 


\subsection{SERVICE UTILIZATION OUTCOMES}

Comparison 7 Service Utilization, Outcome 1 Mental Health Services

\begin{tabular}{|c|c|c|c|c|c|c|c|c|}
\hline \multirow[b]{2}{*}{ Study or Subgroup } & \multicolumn{2}{|c|}{ Control } & \multicolumn{2}{|c|}{ Treatment } & \multirow[b]{2}{*}{ Weight } & \multirow{2}{*}{ Odds Ratio } & \multirow{2}{*}{\multicolumn{2}{|c|}{$\begin{array}{c}\text { Odds Ratio } \\
\mathrm{M}-\mathrm{H}, \text { Random, } 95 \% \mathrm{Cl} \\
\end{array}$}} \\
\hline & Events & Total & Events & Total & & & & \\
\hline Berrick 1994 & 170 & 354 & 72 & 246 & $15.4 \%$ & $2.23[1.58,3.15]$ & & $\longrightarrow$ \\
\hline Bilaver 1999 & 8076 & 33649 & 1552 & 14106 & $17.8 \%$ & $2.55[2.41,2.71]$ & & - \\
\hline Clyman 1998 & 17 & 48 & 4 & 41 & $6.1 \%$ & $5.07[1.54,16.66]$ & & \\
\hline Jenkins 2002 & 68 & 83 & 35 & 52 & $9.5 \%$ & $2.20[0.98,4.93]$ & & \\
\hline Metzger 1997 & 44 & 55 & 43 & 52 & $7.7 \%$ & $0.84[0.32,2.22]$ & & \\
\hline Scannapieco 1997 & 19 & 59 & 11 & 47 & $8.8 \%$ & $1.55[0.65,3.70]$ & & \\
\hline Sivright 2004 & 20 & 67 & 19 & 51 & $9.8 \%$ & $0.72[0.33,1.55]$ & 7 & \\
\hline Sripathy 2004 & 21 & 31 & 20 & 31 & $7.1 \%$ & $1.16[0.40,3.31]$ & & \\
\hline Tompkins 2003 & 66820 & 72404 & 26340 & 29348 & $17.8 \%$ & $1.37[1.30,1.43]$ & & - \\
\hline Total $(95 \% \mathrm{Cl})$ & & 106750 & & 43974 & $100.0 \%$ & $1.69[1.18,2.42]$ & & \\
\hline Total events & 75255 & & 28096 & & & & & \\
\hline $\begin{array}{l}\text { Heterogeneity: } \mathrm{Tau}^{2}= \\
\text { Test for overall effect }\end{array}$ & $\begin{array}{l}.19 ; \mathrm{Chi}^{2} \\
=2.84\end{array}$ & $\begin{array}{l}=285.95 \\
P=0.005)\end{array}$ & $d f=8$ & $<0.00$ & $001) ;\left.\right|^{2}=$ & & 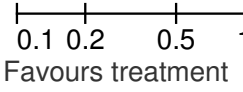 & $\begin{array}{l}1 \\
1 \\
\text { Favours C }\end{array}$ \\
\hline
\end{tabular}

Comparison 7 Service Utilization, Outcome 2 Developmental Services

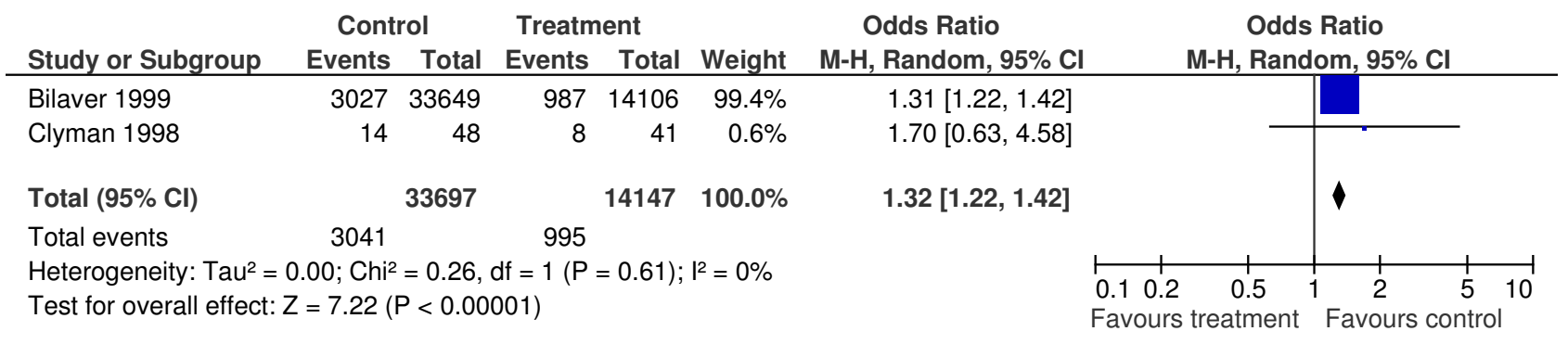


Comparison 7 Service Utilization, Outcome 3 Physician Services

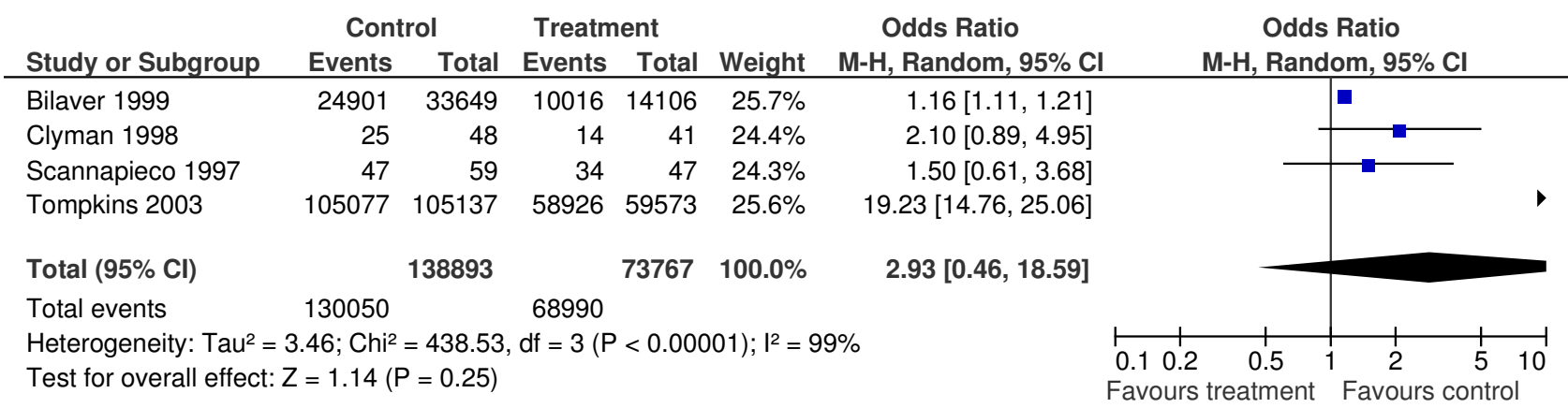

\subsection{RE-ABUSE OUTCOMES}

Comparison 8 Service Re-abuse, Outcome 1 Recurrence of Abuse

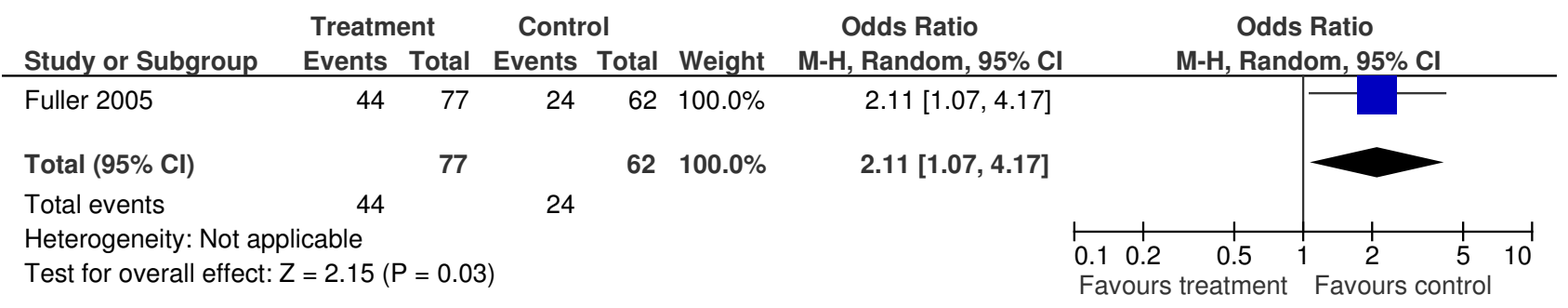


Comparison 8 Service Re-abuse, Outcome 2 Institutional Abuse

Treatment Control Odds Ratio Study or Subgroup Events Total Events Total Weight M-H, Random, 95\% Cl

\begin{tabular}{lllllll}
\hline Benedict 1996a & 10 & 90 & 50 & 180 & $40.1 \%$ & $0.33[0.16,0.68]$
\end{tabular}

Zuravin 1993

$21 \quad 135$

$41 \quad 161 \quad 59.9 \%$

$0.54[0.30,0.97]$

Total $(95 \% \mathrm{Cl})$

225

31

$341 \quad 100.0 \%$

Total events

91

Heterogeneity: Tau $^{2}=0.01 ; \mathrm{Chi}^{2}=1.12, \mathrm{df}=1(\mathrm{P}=0.29) ; \mathrm{I}^{2}=11 \%$

$0.44[0.27,0.72]$

Test for overall effect: $Z=3.30(P=0.0010)$

Odds Ratio M-H, Random, 95\% Cl

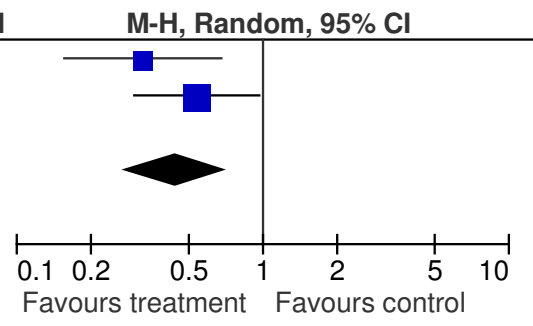

